\title{
القيامة الكبرى
}

\section{مشاهلد ووقائع ، دروس وعبر}

\author{
( دراسة قرآنية )
}

\author{
بقلم \\ د. عبلد الرحمن محمد علي عويس \\ أستاذ التفسير المساعد بكلية أصول الدين جامعة الأزهر بالقاهرة
}


$-\varepsilon \varepsilon-$ 


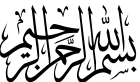

\section{المقلدمــــة}

الحمد لله وكفي وصلاة وسلاماً على عباده الذين اصطفي وبعد: فلقد جعل الحق سبحانه الإيمان بيوم البعث ركناً من أركان الإيمان التي لا يتت

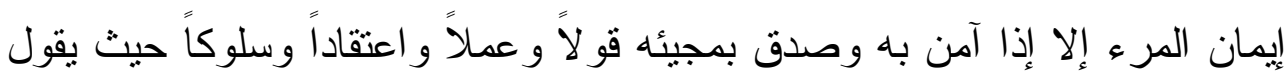

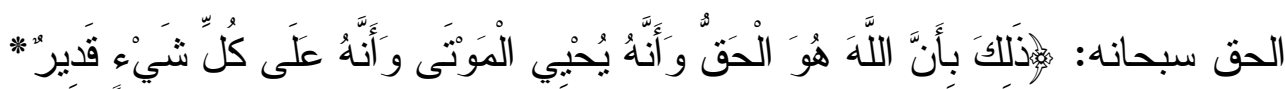

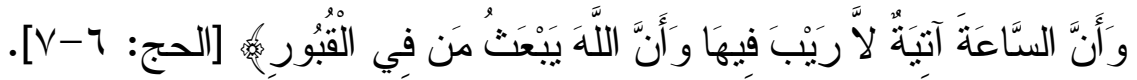

ومن هنا يعتبر يوم القيامة صمام أمان للبشرية جمعاء، يحول بينهم وبين

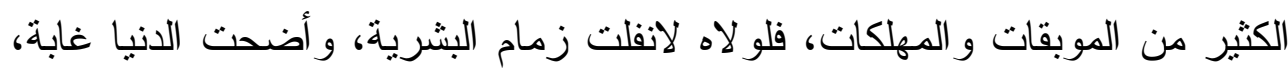

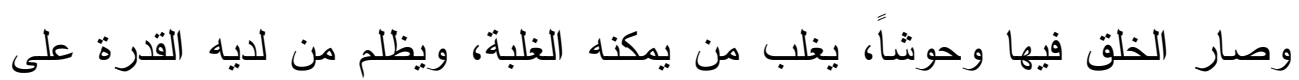

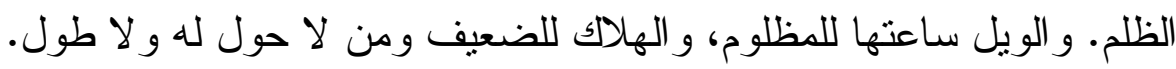

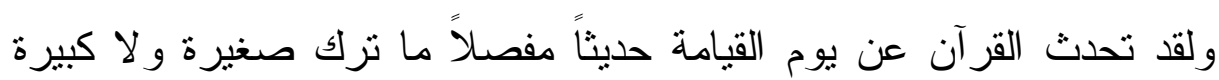
تحدث في هذا اليوم إلا وفصلها، و لا شاردة أو واردة إلا وأخبرنا عنها سبحانه وتعالى في كتابه، وذللك حتى لا تبقى لأحد من الناس عند الله حجة كما قال سبحانه:

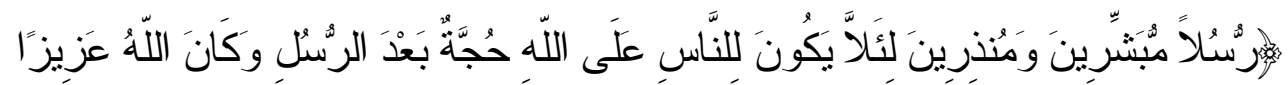

$$
\text { حكيمًا [النساء: }
$$

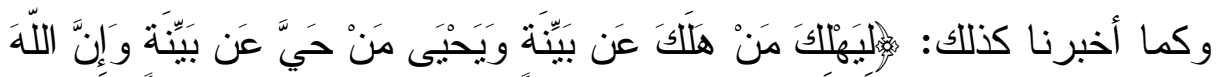

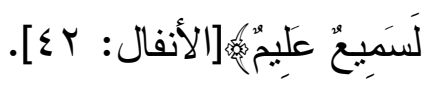

وفي مؤلف سابق تحدثت عن الموت أو القيامة الصغرى، وبينت من خلاله رحلة العبد مع الموت، و الطريق الذي يمشي فيه العبد وحده للقاء ربه سبحانه 
القيامة الكبرى (مشاهد ووقائع، دروس وعبر)

وتعالى، وبينت من خلاله أن الموت هو القيامة الصغرى، وأن من مات فقد قامت قيامته، وتحدثت كذلك عن أثثر اط الساعة وعلاماتها الصغرى و الكبرى كذلك،

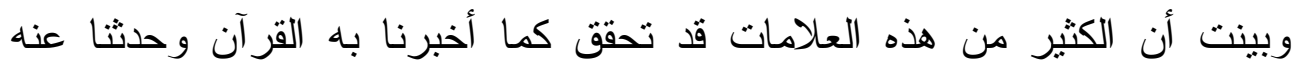
الرسول : بمجيئه ووقو عه، فيكفي أن يخبرنا به المولى سبحانه حتى نوقن بأنه آت لا محالة.

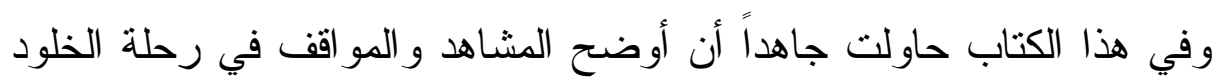

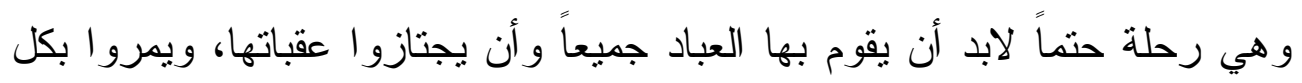

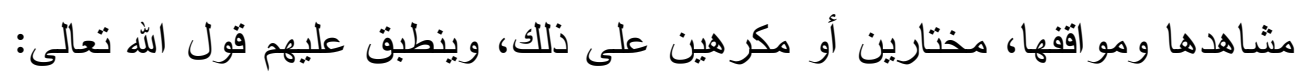

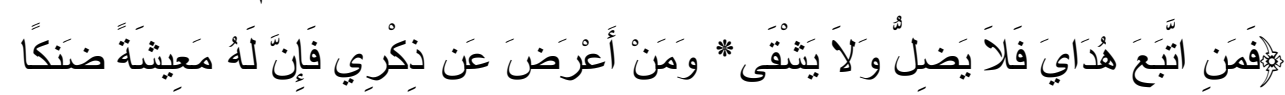

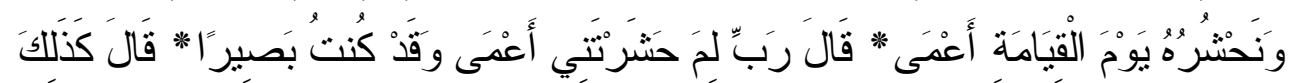

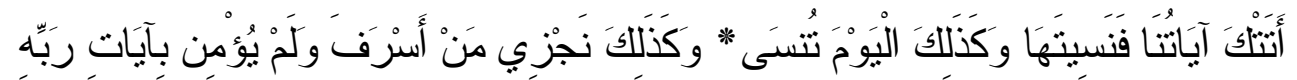

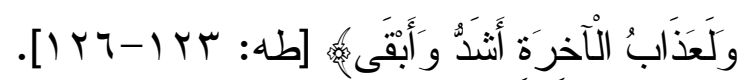

ولقد حاولت في هذا الكتاب أن أبين أحداث القيامة ومواقفها، وأن أوضحها على حسب وقوعها وتسلسلها، وكأنها رحلة يمر بها العبد في طريقه إلى دار

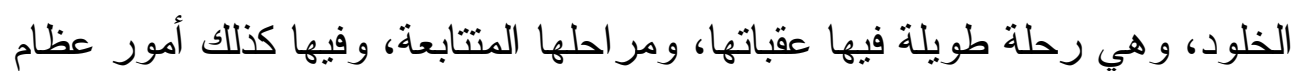

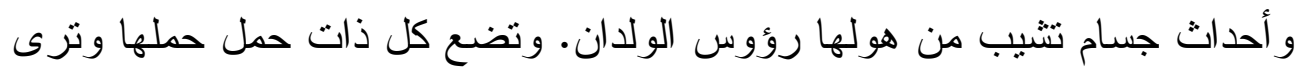
الناس سكارى وما هم بسكارى ولكن عذاب الله شديد.

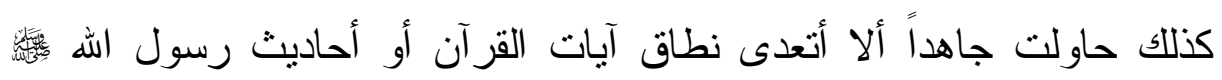

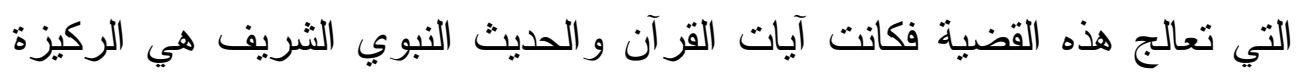
التي اعتمدت عليها في كتابة هذا البحث، وكان عملي في مواضع اضع كثيرة شرحاً

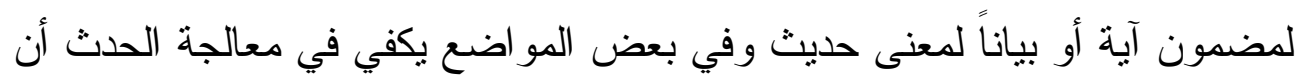


أذكر فيه نص آية من كتاب الله تعالى، أو حديث عن رسول الله

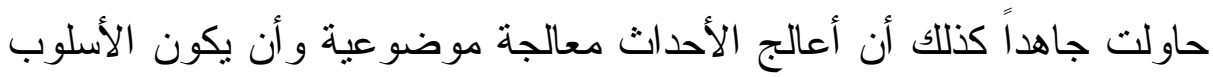

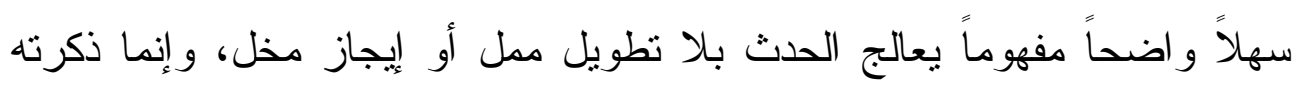

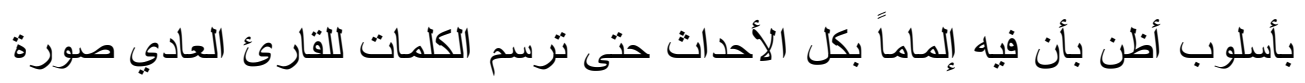

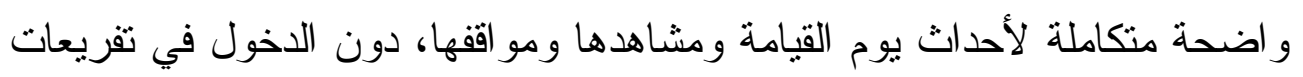
أو الخوض في تقصيلات لا يحتاج إليها القارئ، و لا تفيده كثير اً في هذا الأمر . ومن الأمور المهمة كذلك ونحن نتحدث عن يوم القيامة يجب أن نوقن بأن يوم القيامة غيب، وأن أحداثه ووقائعه ومشاهده كل هذه أمور من عالم الغيب، فينبغي

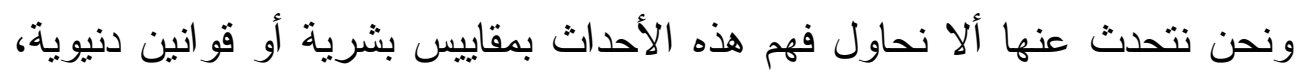

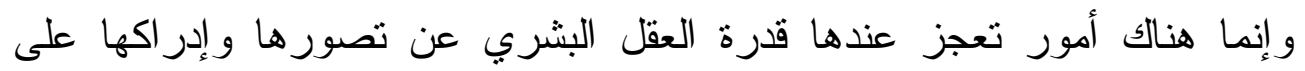
حقيقتها فينبغي ألا يحاول الإنسان فهيها بعلم البشر أو بما تعارفو ا عليه في دنياهم من نو اميس وقو انين وسنن فهي خارج نطاق حو اسهم وفوق إمكانات عقو لهم.

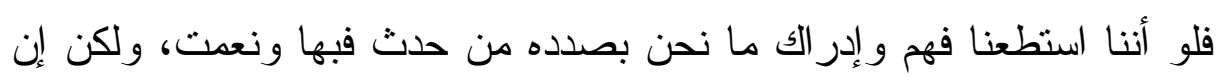

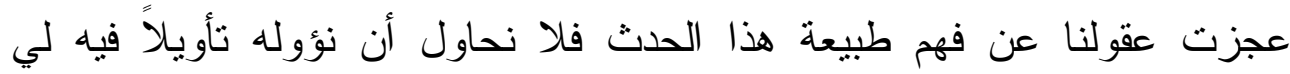

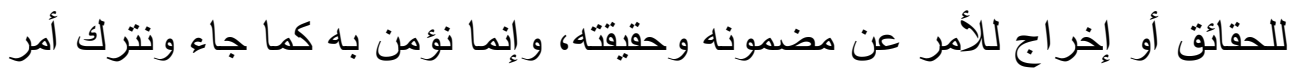
حقيقته إلى علم الله سبحانه وتعالى، خاصة وأن النو اميس و القو انين و السنن التي

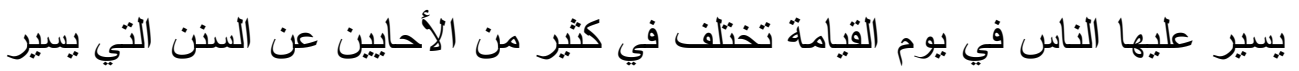

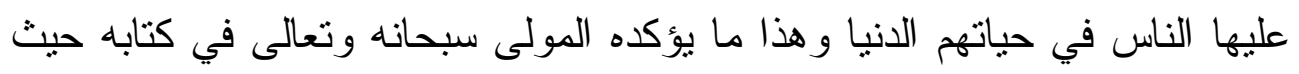

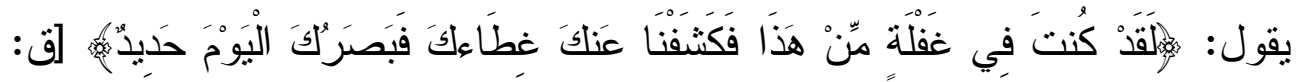

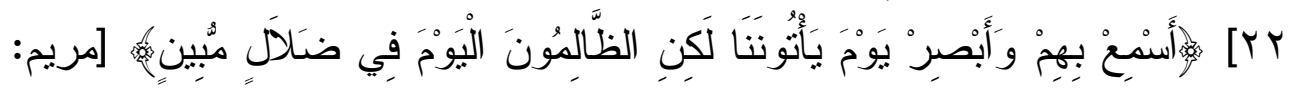


القيامة الكبرى (مشاهد ووقائع، دروس وعبر)

حاولت كذلك أن أعبش مع فقه الحدث و الموقف الذي يمر به العبد في رحلة

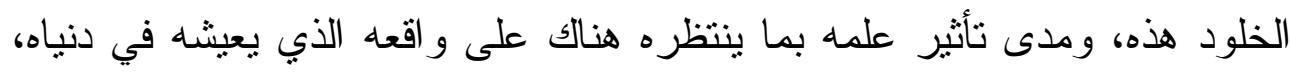

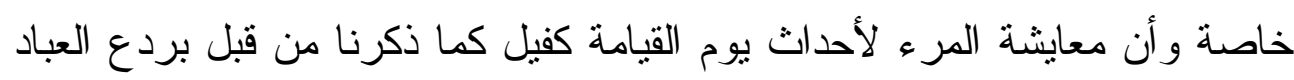

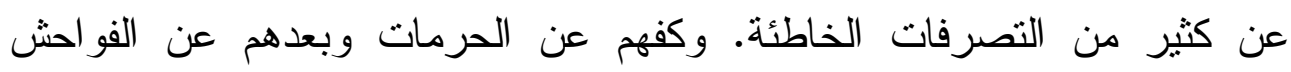
و الموبقات.

من خلال البحث كذلك ظهر جلياً بأن الحق سبحانه لم يخلق عباده عبثاً ولن

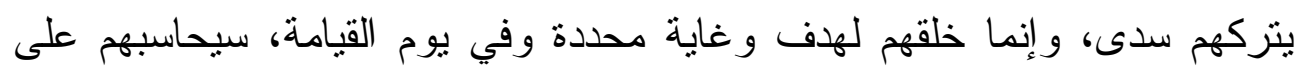

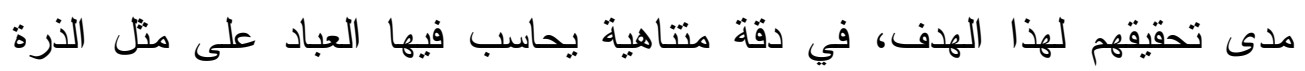

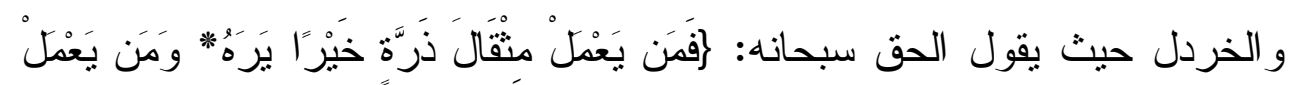

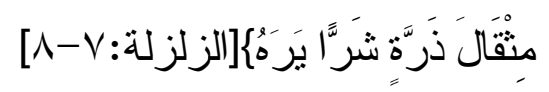

وبعد فهذا جهد المقل فما كان فيه من صو اب فمن الله وحده وله الفضل و المنة وما كان فيه من تقصير أو خطأ فمن نفسي والكمال لله وحده. والحمد لله أولاً ووآخراً. 
القيامة الكبرى (مشاهد ووقائع، دروس وعبر)

مدخل: في بيان جاتب من أسماء يوم القيامة:

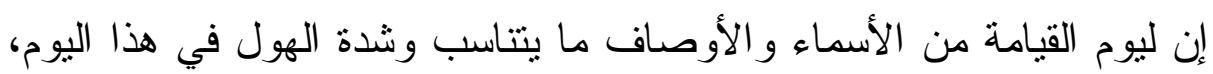
فمن خلال تتبع الآيات التي تحدثت عن يوم القيامة سنجد الكثير من الأسماء

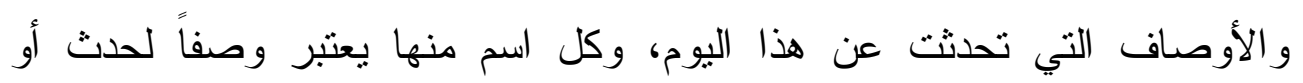
تصوير اً لثدة الهول و الكرب في هذا اليوم تلك التي تمثلت في كل ما يتعلق بأمر هذا اليوم، حتى في أسمائه و أوصافه فمن أسمائه:

1- يوم القيامة: وهي مصدر قام يقوم، ودخلها التأنيث للمبالغة، وسميت بذلك

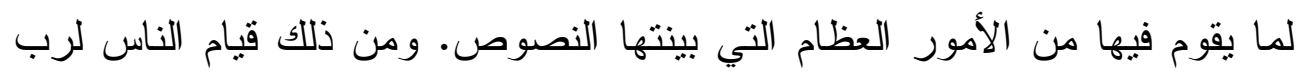
العالمين.

ولقد ورد هذا الاسم في سبعين آية من آيات الكتاب، كقوله تعالى: (اللَّهُ لا إلَََّ

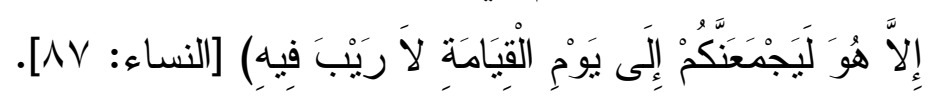

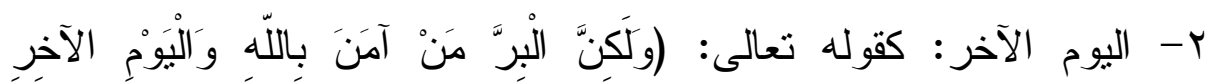

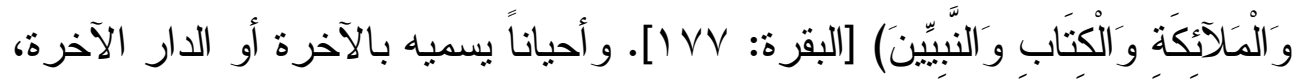

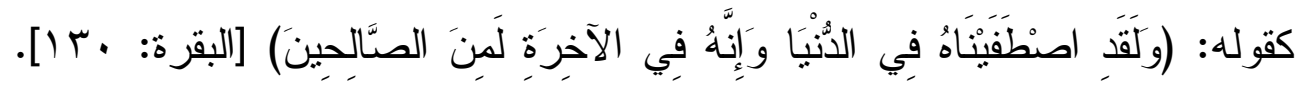

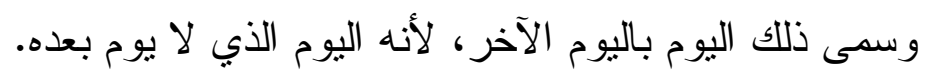

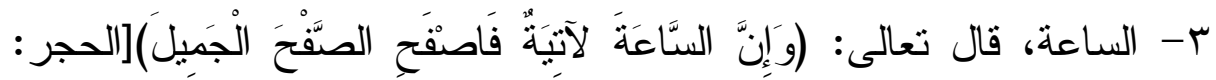

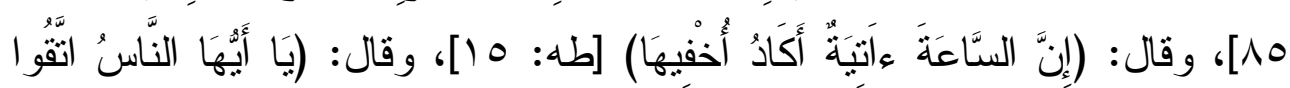

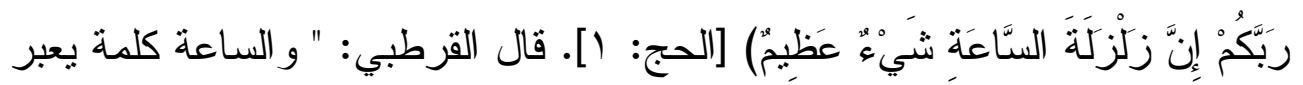
بها في العربية عن جزء من الزمان غير محدود، وفي العرف على جزء من من أربعة

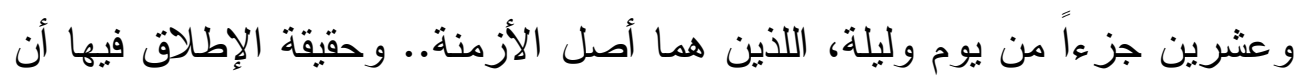

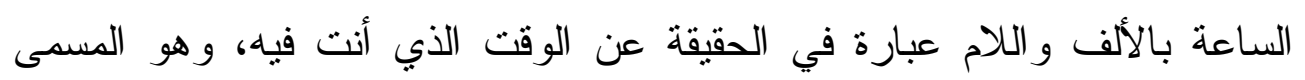


بالآن، وسميت به القيامة إما لقربها، فإن كل آت قريب. و إما أن تكون سميت بها

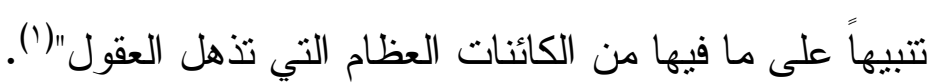

ـ - يوم البعث: قال ابن منظور: " البعث: الإحباء من الله نعالى للموتى،

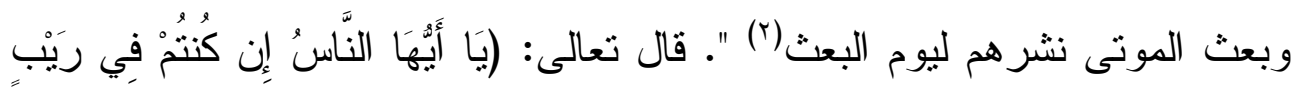

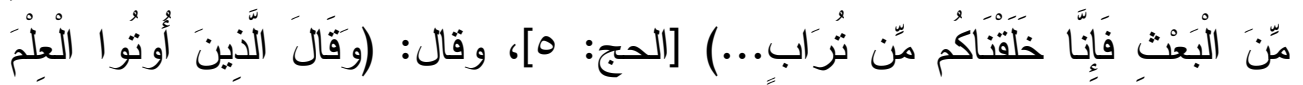

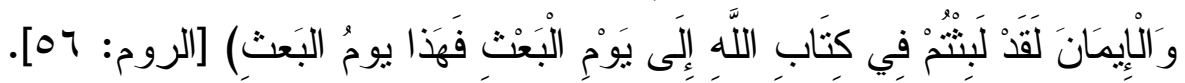

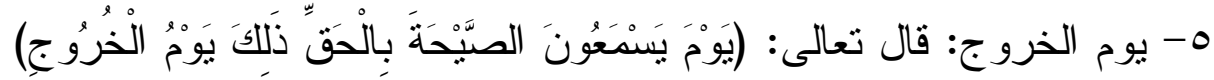

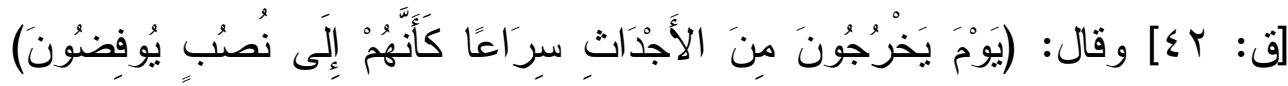

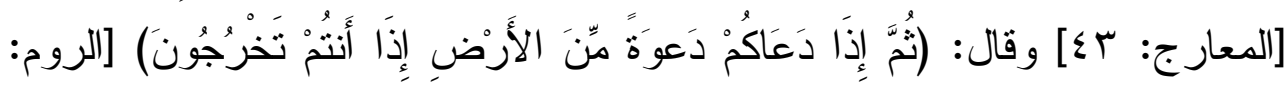

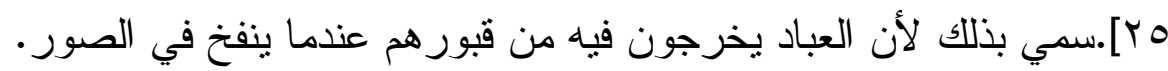
צ- القارعة: سميت بذللك لأنها تقرع القلوب بأهو الها. يقال: قد أصابتهم

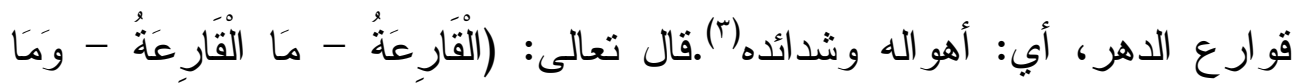

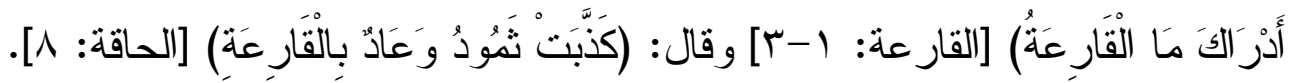

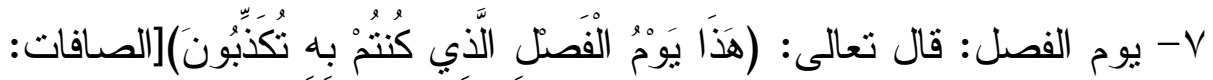

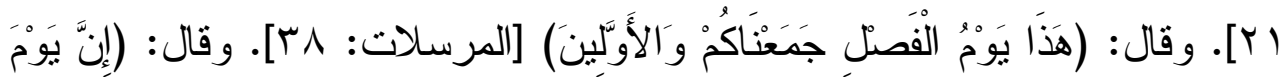

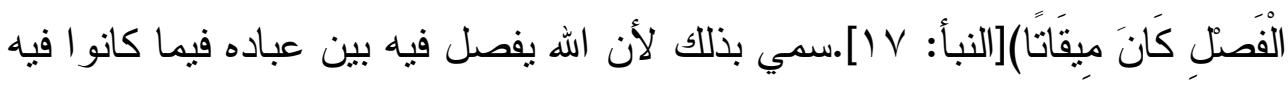

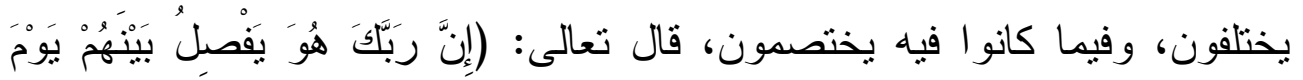

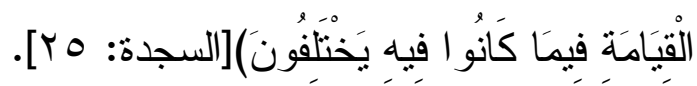

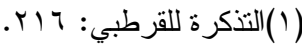

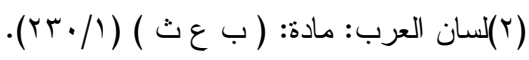
(r) التذكرة للقرطبي: 9 .r. 
1- يو الدين: و الدين في لغة العرب:يطلق علي معانَ منها الجز اء و الحساب. سمي بذللك لأن الله يجزي العباد ويحاسبهم في ذللك اليوم. قال تعالى : (وَإِنَّ الْفُجَّارَ

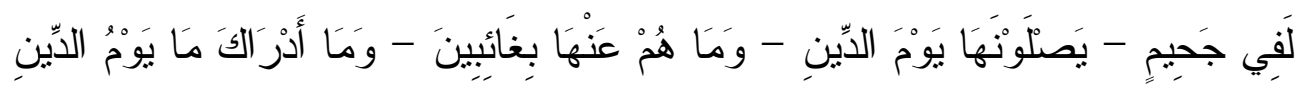

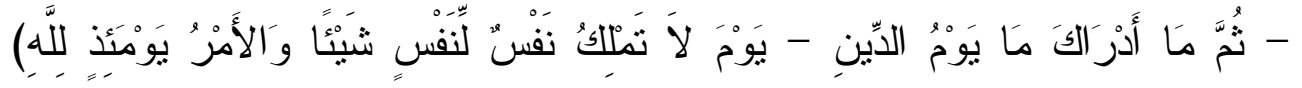

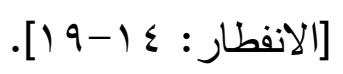

9- الصاخة: شدة صوت ذي النطق، يقال: صخ يصخ صخا فهو صاخ. قال

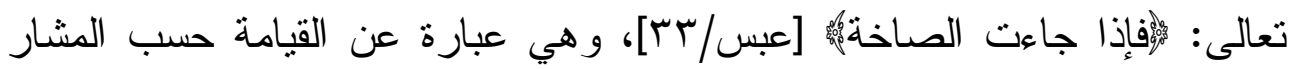

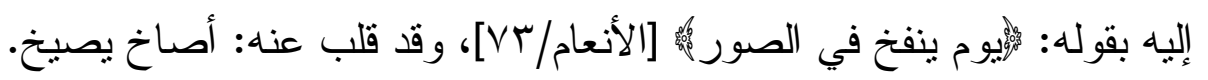
قال القرطبي: " قال عكرمة: الصاخة النفخة الأولى " والطامة النفخة الثانية.

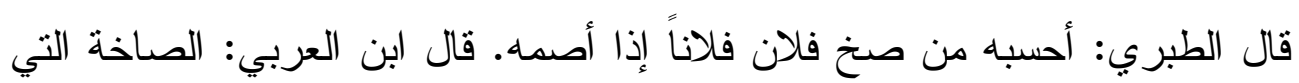

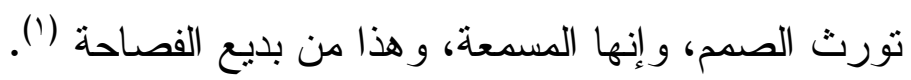
وقال ابن كثير : " قال البغوي: الصاخّة يعني صيحة يوم القيامة، سميت بذلك

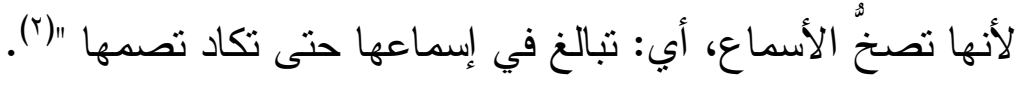

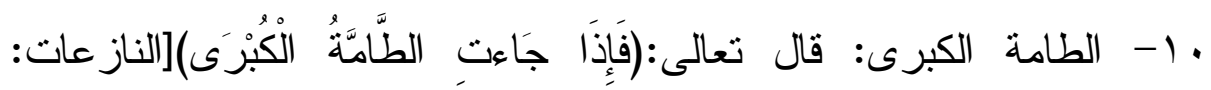

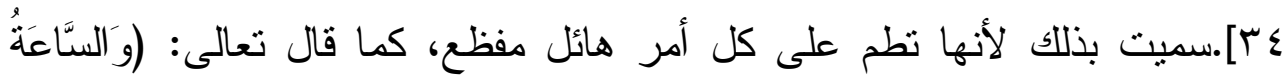

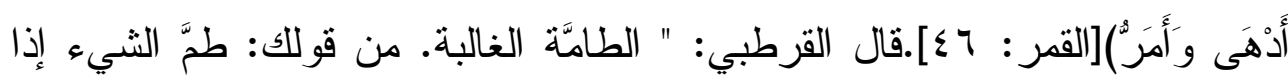
علا و غلب. ولما كانت تغلب كل شيء كان لها هذا الاسم حقيقة دون كل شيء (َ)"). 11- يوم الحسرة: و الحسرة الغم على ما فاته و الندم عليه، كأنه انحسر عنه 
الجهل الذي حمله على ما ارتكبه، أو انحسر قو اه من فرط غم، أو أدركه إعباء من

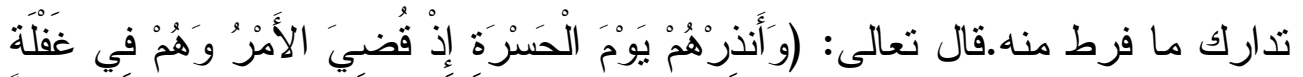

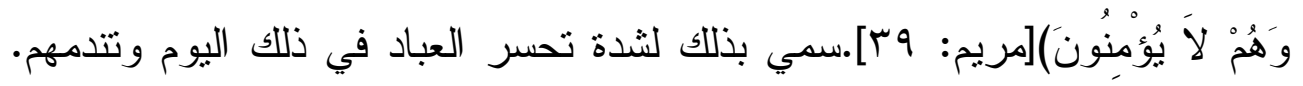

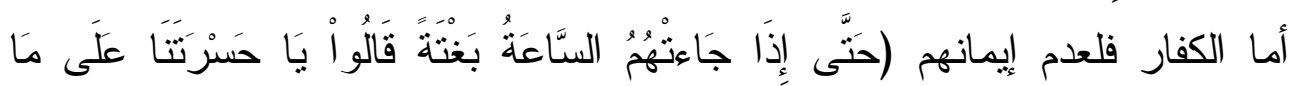

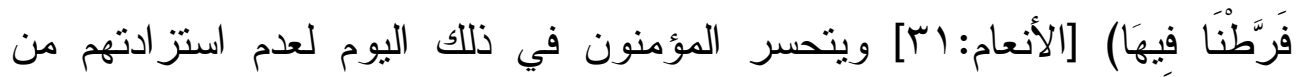
أعمال البر و التقوى.

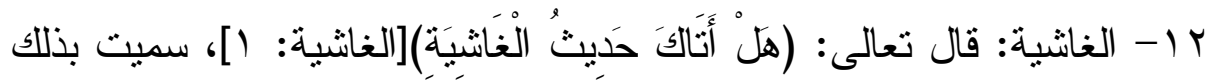
لأنها تغشى الناس بأفز اعها وتغهر، ومن معانيها أن الكفار تغشاهم النار، وتحيط

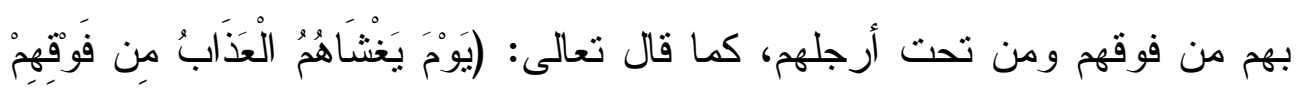

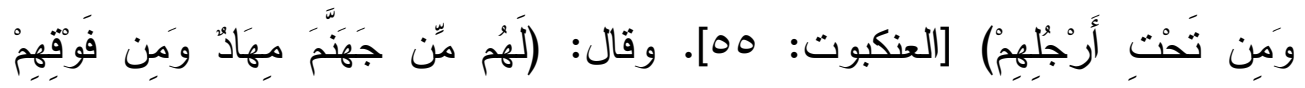

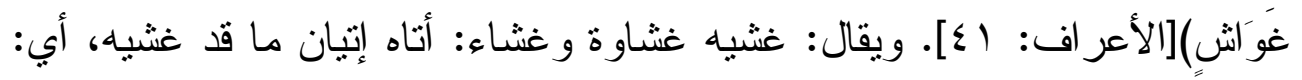

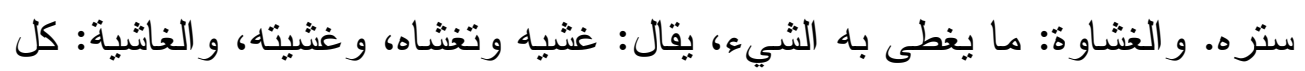

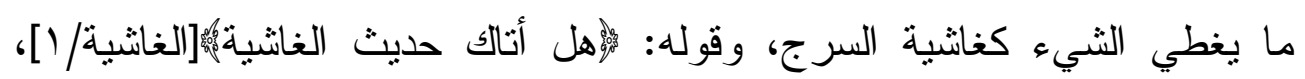
كناية عن القيامة.

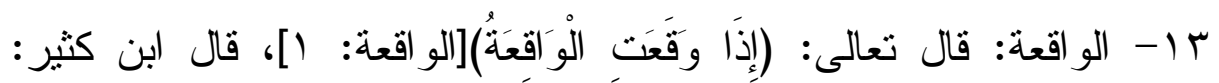

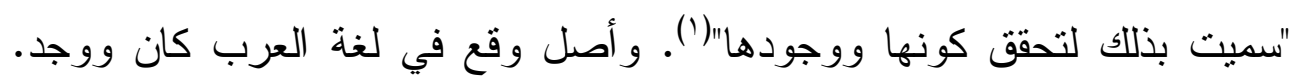

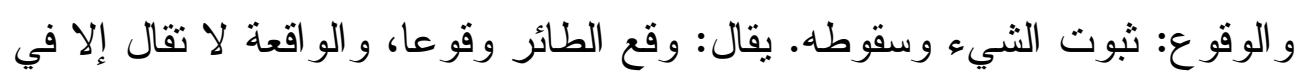

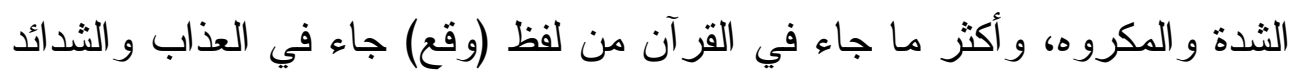

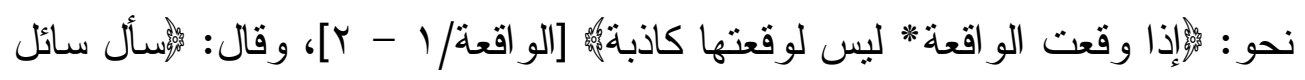

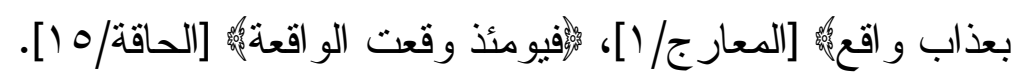




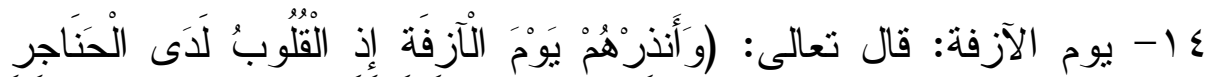

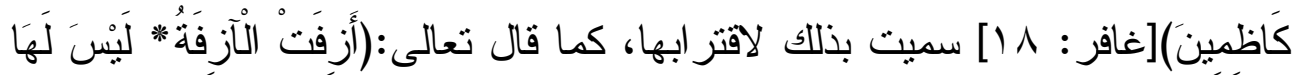

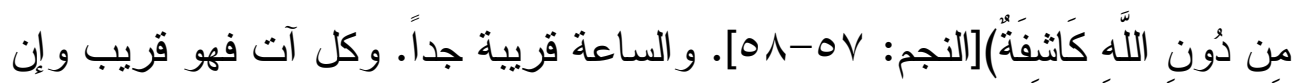
بَعُدْ مداه.

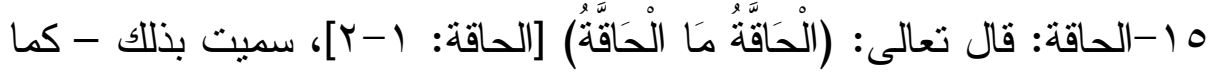
يقول ابن كثير - لأن فيها يتحقق الوعد و الوعيد (').

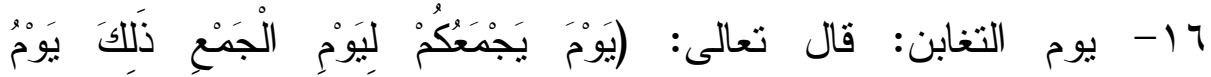

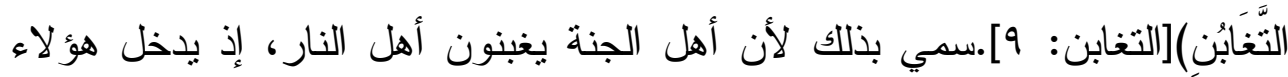

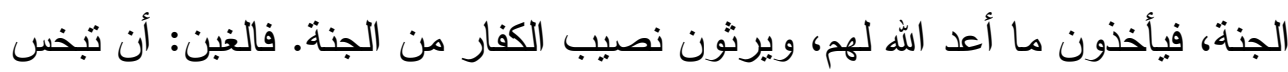
صاحبك في معاملة بينك وبينه بضرب من الإخفاء.

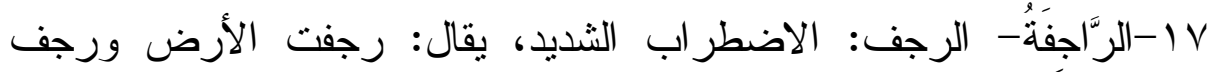

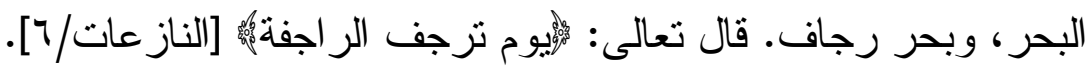
1)-الزَّلزَكَّة و التزلزل: الاضطر اب، وتكرير حروف لفظه نتبيه على تكرير

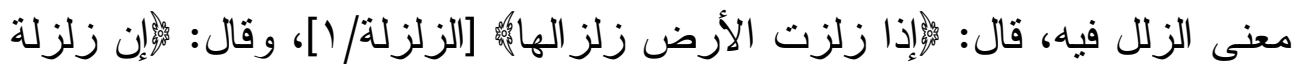

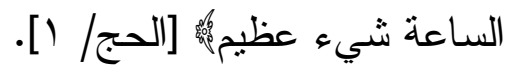
هذه مجموعة من أنشهر أسماء يوم القيامة، وقد أورد بعض العلماء أسماءً

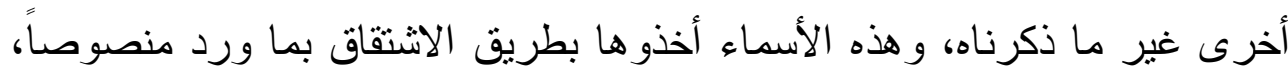

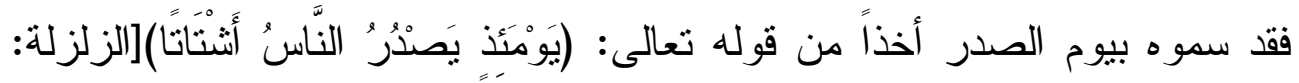

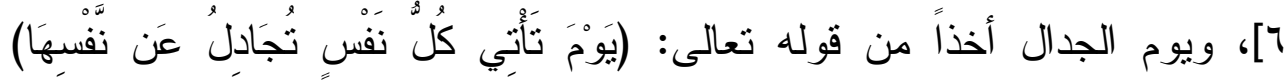
[النحل: 111] 
وسموه بأسماء الأوصاف التي وصف الله بها ذلك اليوم، فقالو امن أسمائه: يوم عسير • يوم عظيم. يوم مشهود. يوم عبوس قمطرير • ويوم عقيم. يوم الخلود. يوم الجمع. يوم الوعيد. يوم الحساب. يوم المآب. يوم العرض. يوم الخافضة يوم التلاق - يوم التتاد.يوم الر افعة. يوم القصاص. يوم الجزاء. يوم الناقور. يوم التفرق. يوم الصدع. يوم البعثرة. يوم الندامة. يوم الفرار . ويوم الميقات. و المرصاد.

وقد يضيف إلبها بعض أهل العلم أسماء أخرى، وقد يسمى الاسم بما يقاربه ويماتله، قال القرطبي: " و لا يمتتع أن تسمى بأسماء غير ما ذكر بحسب الأحوال الكائنة فيه من الازدحام والتضايق واختلاف الأقدام، و الخزي، و الهوان، و الذل، و الافتقار ، و الصنَّار ، و الانكسار ، إلى غير ذلك من الأسماء (')".

السر في كثرة أسمائه: يقول القرطبي: " وكل ما عظم شأنه تعددت صفاته، وكثزت أسماؤه، وهذا مهيع كلام العرب، ألا ترى أن السيف لما عظم عندهم موضعه، وتأكد نفعه لديهر وموقعه، جمعو الله خمسمائة اسم، وله نظائر • فالقيامة لما عظم أمر ها، وكثرت أهو الها، سماها الله تعالى في كتابه بأسماء عديدة، ووصفها

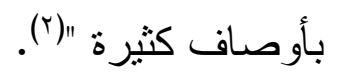

\section{بداية الأحداث: النفخ في الصور:}

لقد بينا في كتاب سابق أثر اط الساعة وتحدثا عن علاماتها الصغرى و الكبرى، ووضحنا بأن هذه العلامات تتو الى وتثتابع منذ بعثة رسول الله مجيء العلامات الكبرى ينبئ بدنو يوم القيامة وقربه، وسنكون الساعة حينئ 
القيامة الكبرى (مشاهد ووقائع، دروس وعبر)

كالحامل المتم لا بدري أهلها متى تفجؤهم بو لادتها، فإذا ما نو الت هذه العلامات

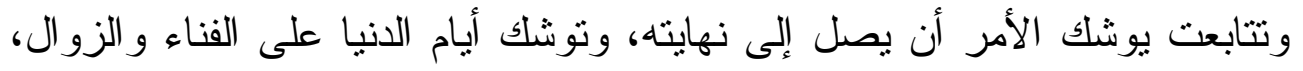

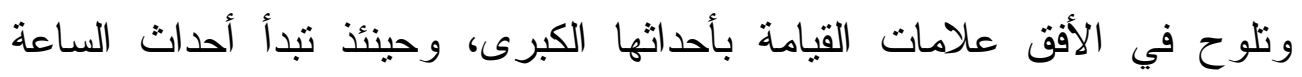

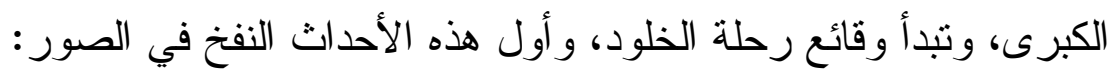
النفخ في الصور:

لقد استخلف الحق سبحانه آدم وذريته في الأرض، وقدر لهم فيها آجالاً

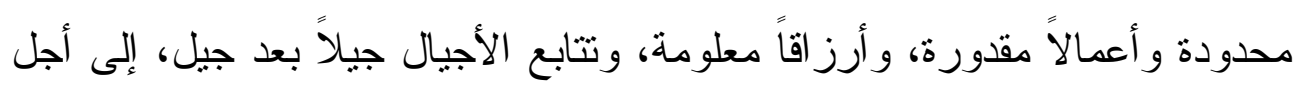

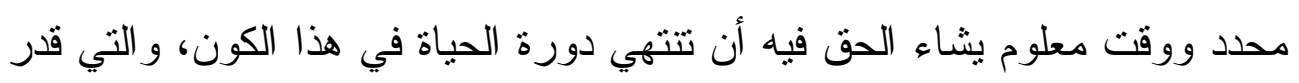

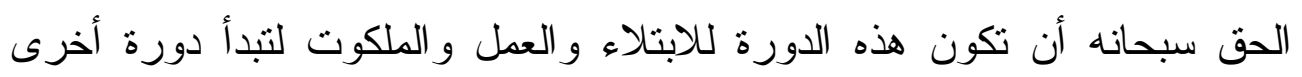

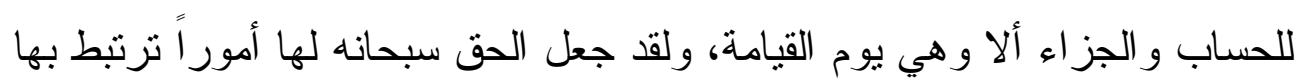
و أسباباً تؤذن بمجيئها ووقو عها أما ما يرتبط بيوم القيامة من أمور منها:

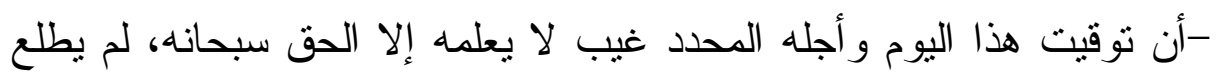

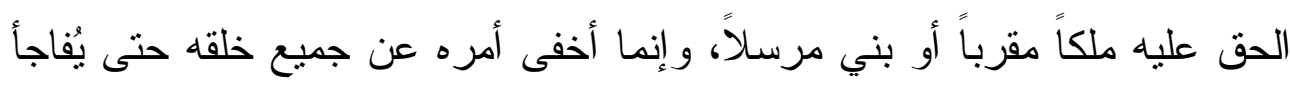

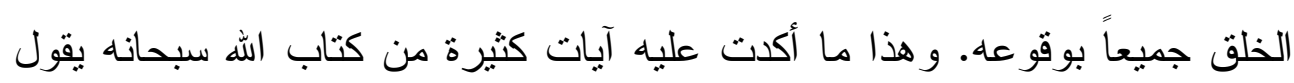

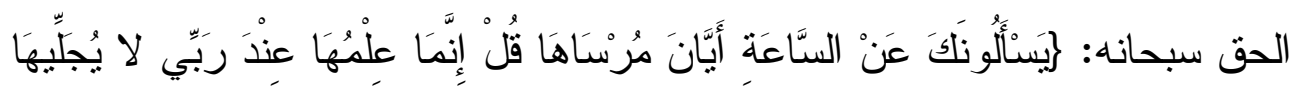

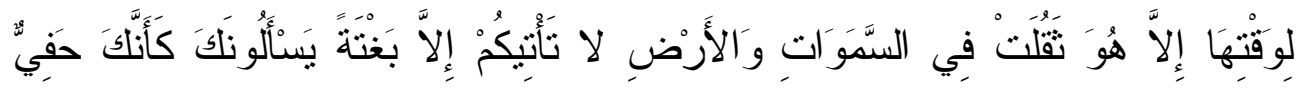

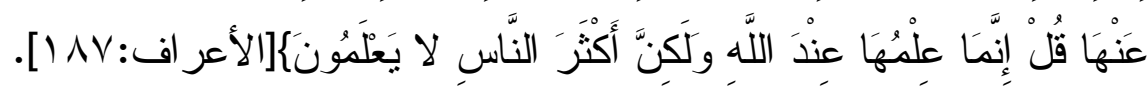

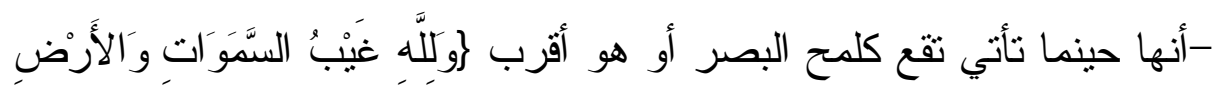

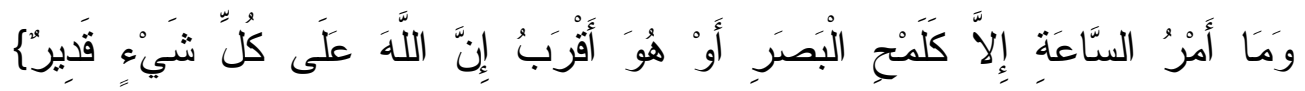
[النحل:VV]

-أن الحق سبحانه قادر على أن يُفني الوجود كله في لمح البصر والأمر كما 
القيامة الكبرى (مشاهد ووقائع، دروس وعبر)

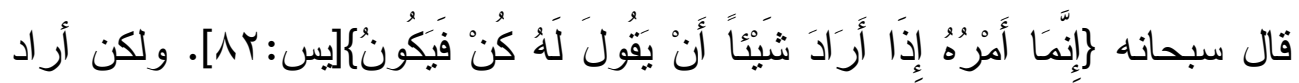

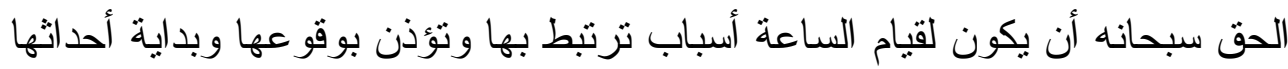

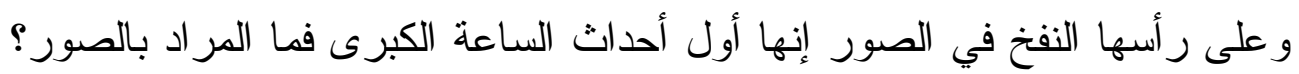
وكيف يتم النفخ فيه؟ وما الذي يجرى على إثر ذللك:

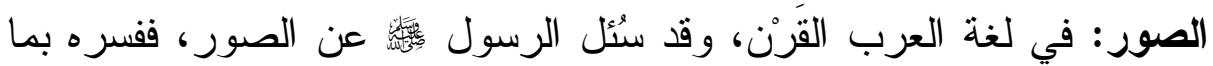
تعرفه العرب من كلامها، ففي سنن الترمذي وسنن أبي داود، وسنن ابن حبان،

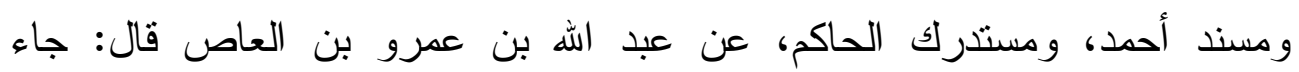

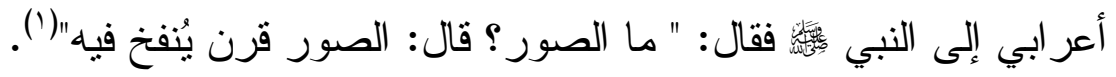
هذا ما نعرفه عن الصور فهو ما تعارف عليه العرب في لغتهم أنه القرن، أو البوق الذي ينفخ فيه فتصدر عنه أصوات مختلفة، فهو ما ينفخ فيه في يوم القيامة،

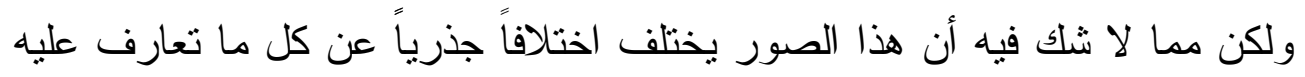

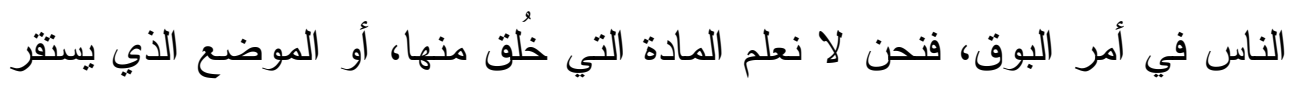

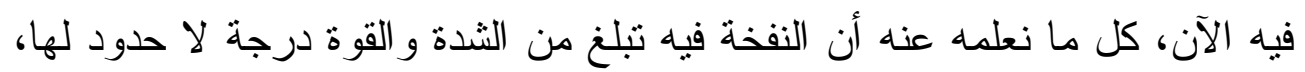

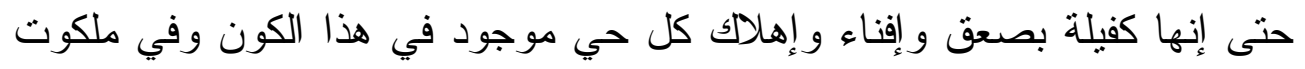

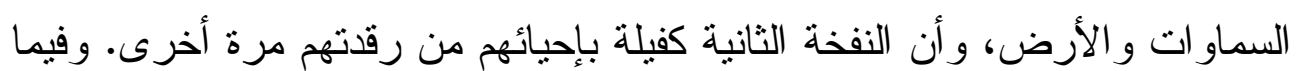

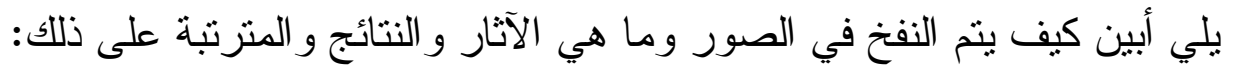
الآيات والأحاديث التي تثبت أمر النفخ في الصور:

لقد تتاولت آيات كثيرة في كتاب الله تعالى قضية النفخ في الصور فتارة

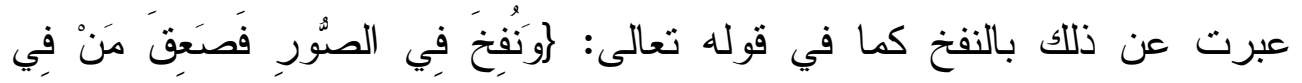
( ()قال الحاكم: صحيح الإسناد، وو القه الأهبي، وقال التزمذي فيه: حديث حسن صحيح.ولفظها لسنن أبي

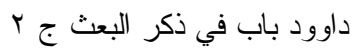




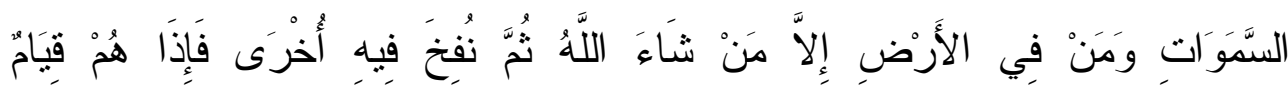

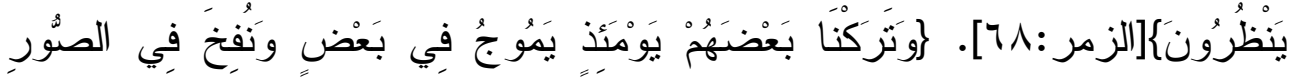

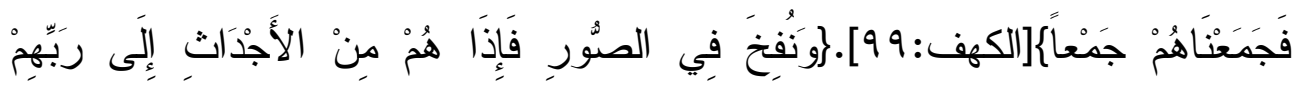

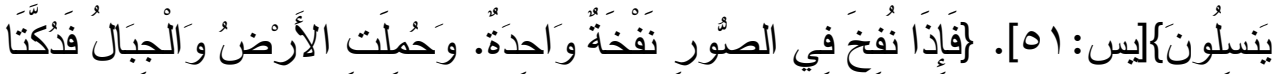

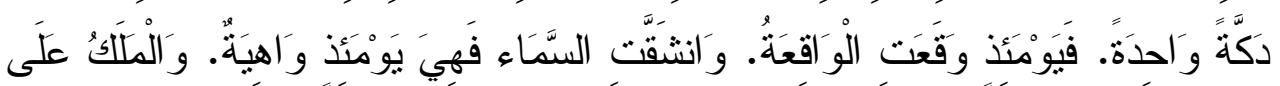

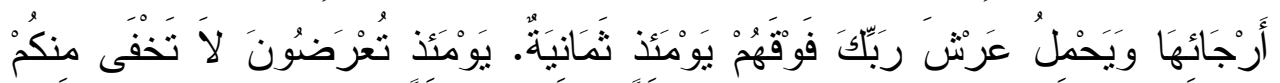

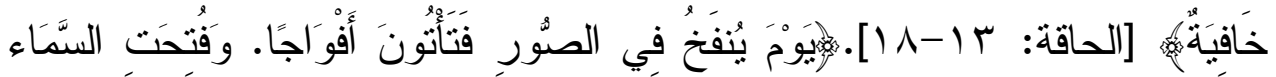

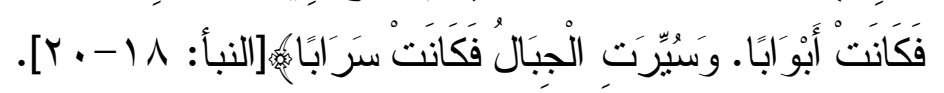

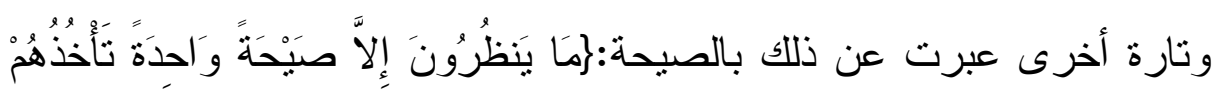

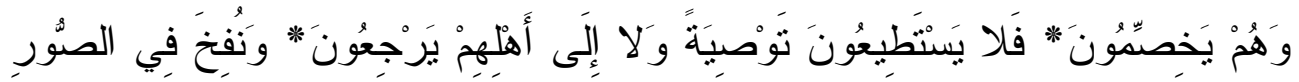

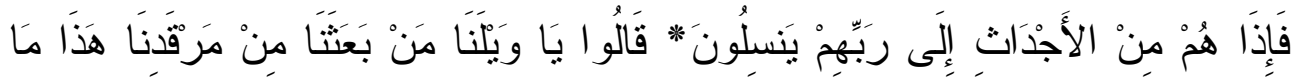

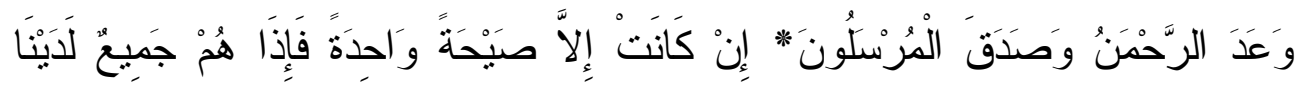

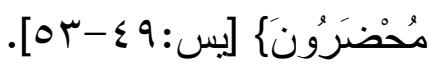

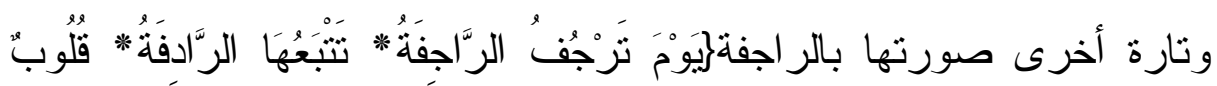

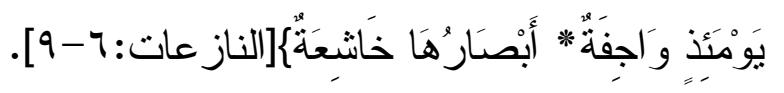

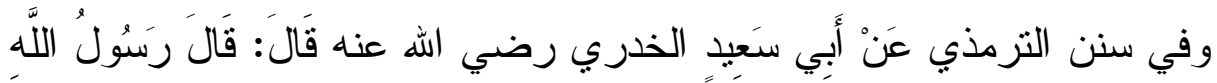

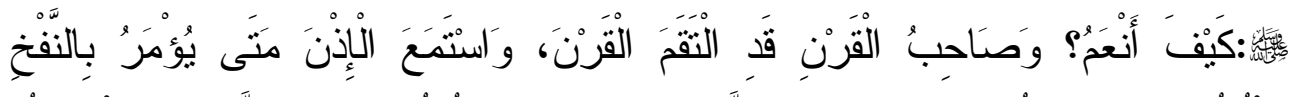

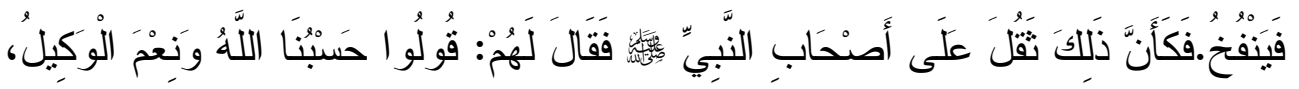

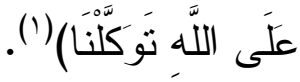
قال ابن حجر العسقاني: " اثتهر أن صاحب الصور إسرافيل عليه السلام، ( (1) سنن الترمذي. كتاب صفة القيامة والرقائق و الور ع. باب:ما جاء في شأن الصور 
ونقل فيه الحليمي الإجماع، ووقع التصريح به في حديث وهب ابن منبه، وفي

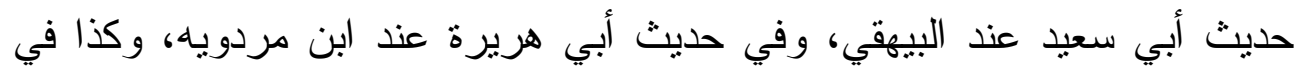

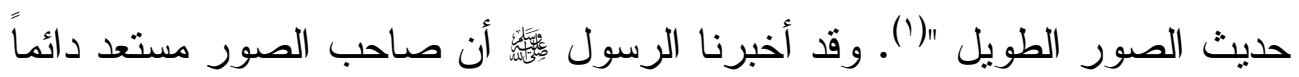

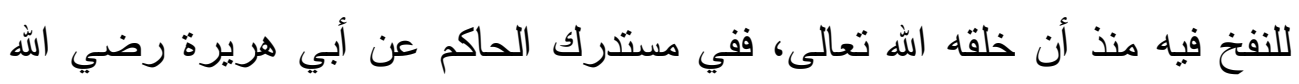

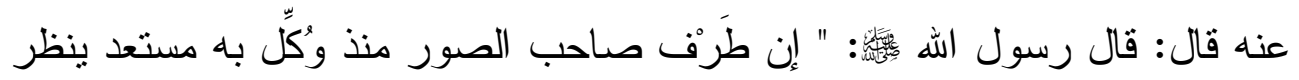

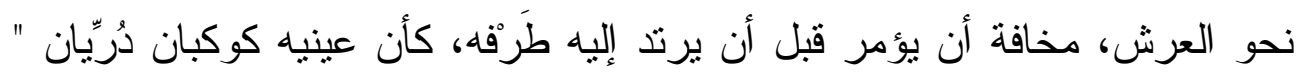
قال الحاكم: صحيح الإسناد، وو اققه الذهبي (؟).

\section{نظلص من هذه النصوص إلى ما يلي:}

- أن النفخ في الصور إيذان بنهاية الحياة الدنيا وبداية الحياة الآخرة. -أن هناك ملكاً موكلاً بالنفخ في الصور وأنه قد أخذ وضع الاستعداد للنفخ

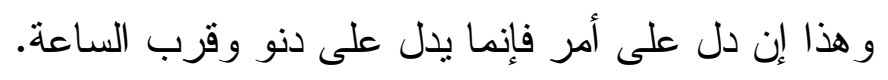

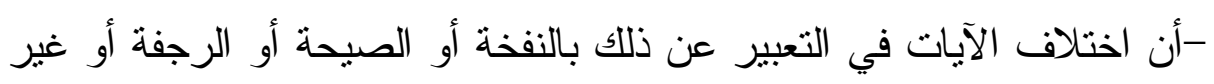
ذلك، كل ذلك تصوير لأمر واحد ألا وهو بداية أحداث القيامة فهي تبدأ بنفخة في

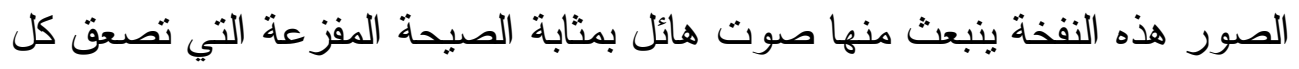

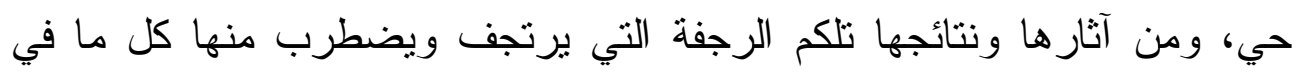
السماو ات و الأرض. ولكن هل هما نفختان أم نفخة واحدة خلاف بين العلماء بيانه

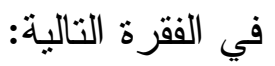

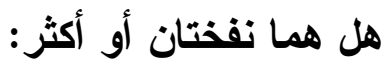

إن صريح آيات القرآن ذكرت أنهما نفختان نفخة الصعق ونفخة الإفاقة 


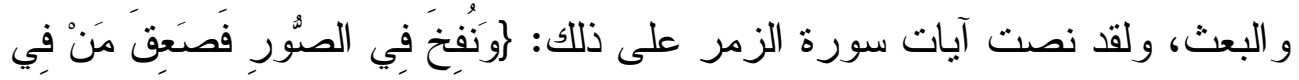

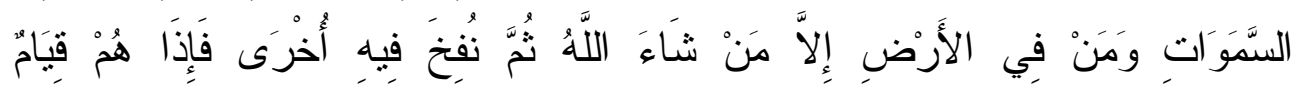

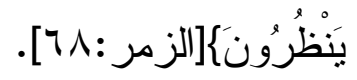

وسورة النازعات نصت على ذللك حينما بينت بأن الر اجفة تتبعها الر ادفة:إيوْمَ

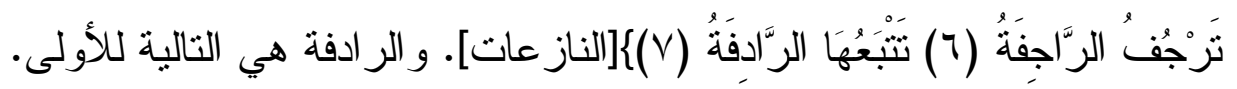

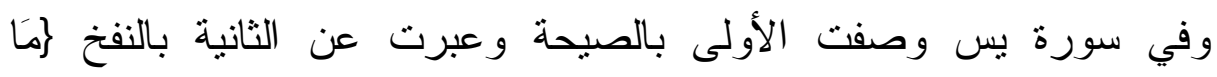

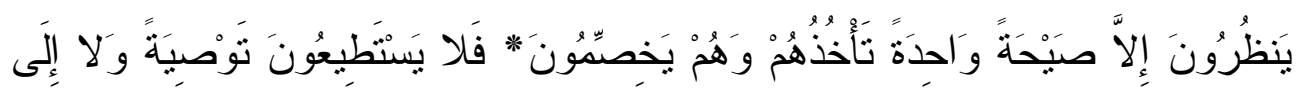

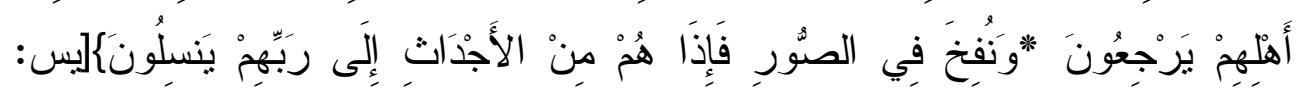
$[0]-\varepsilon 9$

وقد جاءت الأحاديث النبوية مصرحة بالنفختن، ففي صحيح البخاري ومسلم

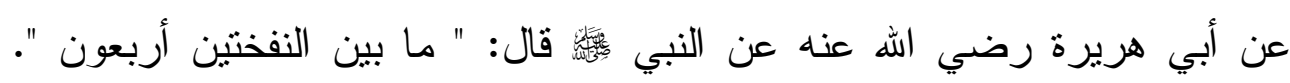

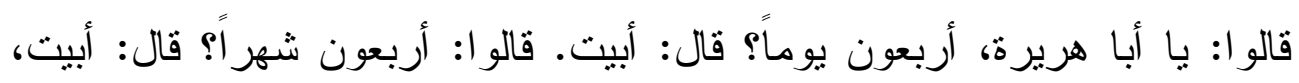

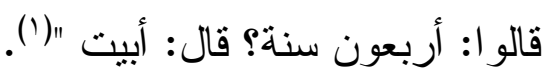

وفي صحيح مسلم عن عبد الله بن عمرو بن العاص أنه سمع رسول الله

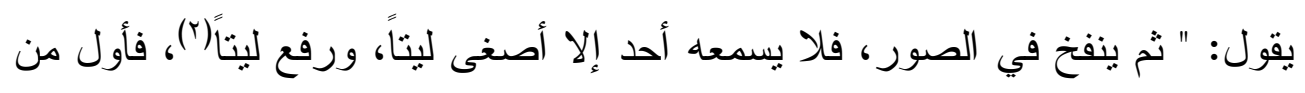

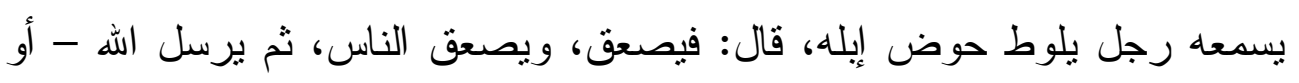

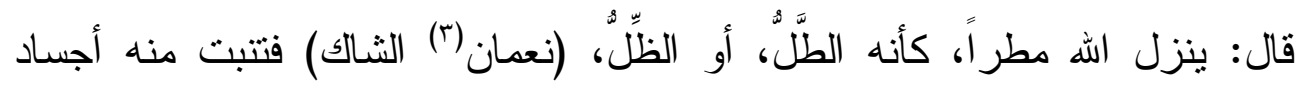

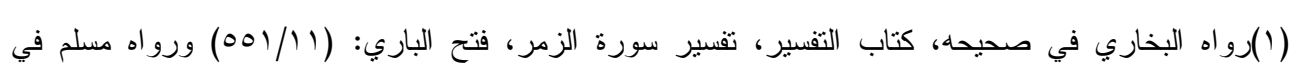

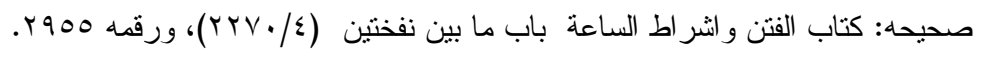

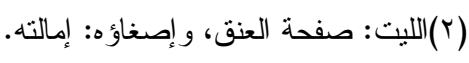
(r) هو نعمان بن سالم أحد رو اة هذا الحديث. 
القيامة الكبرى (مشاهد ووقائع، دروس وعبر)

الناس، ثم ينفخ فيه أخرى فإذا هم قيام ينظرون"( ).

وأخرج البيهقي بسند قوي عن ابن مسعود موقوفاً: " ثم يقوم ملك الصور بين

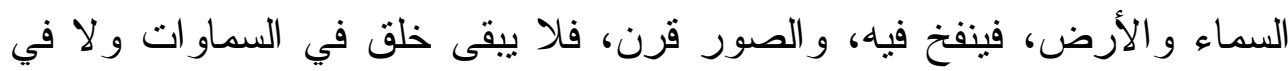
الأرض إلا مات إلا من شاء ربك، ثم يكون بين النفختين ما شاء الله أن يكون" (؟).

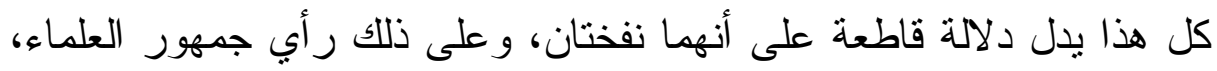

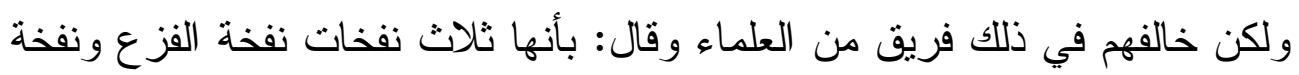

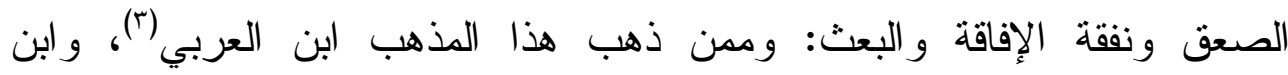

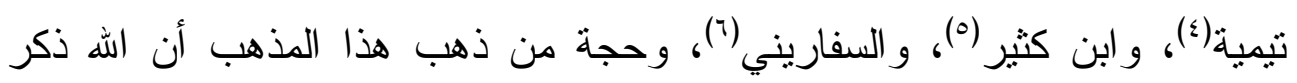

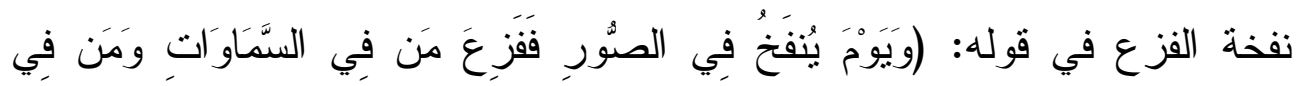

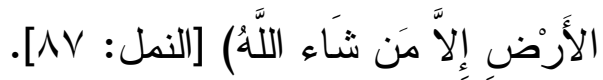

كما احتجوا ببعض الأحاديث التي نصت على أن النفخات ثلاث، كحديث الصور، وهو حديث طويل، أخرجه الطبري، وفيه: " ثم ينفخ في الصور ثلاث نفخات: نفخة الفزع، ونفخة الصعق، ونفخة القيام لرب العالمين (ل)"ا.

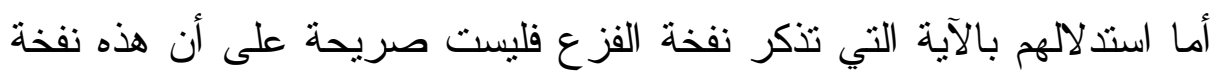

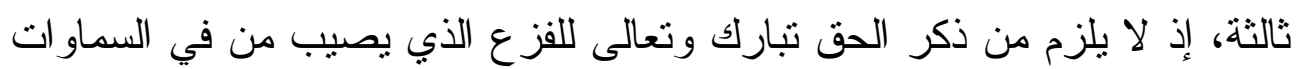

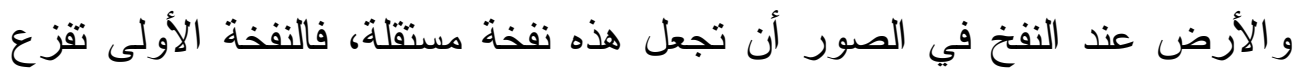

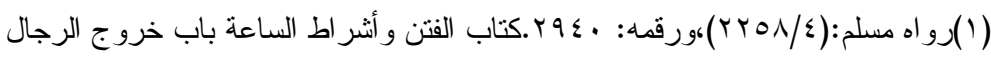

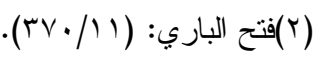

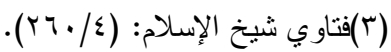

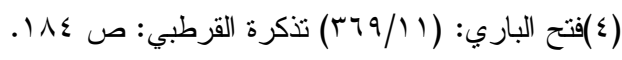

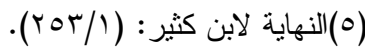

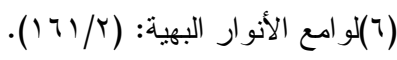

$$
\begin{aligned}
& \text { (Y) }
\end{aligned}
$$


القيامة الكبرى (مشاهد ووقائع، دروس وعبر)

الأحياء قبل صعقهم، و النفخة الثانية تفزع الناس عند بعثهم.

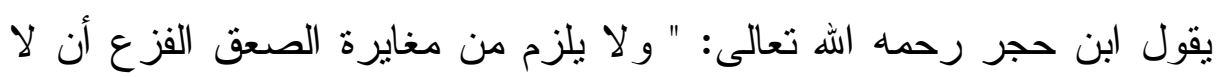

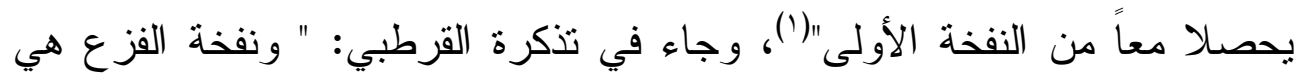

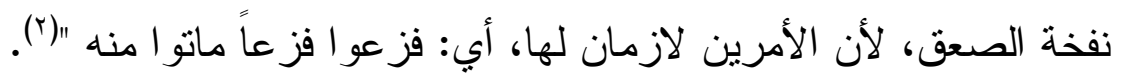
أما حديث الصور فهو حديث ضعيف مضطرب كما يقول الحجة في علم الحديث ابن حجر العسقلاني رحمه الله تعالى، ونقل تضعيفه عن البيهقي (r).

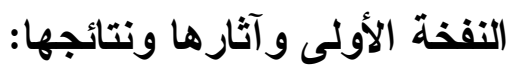

إذا ما أذن المولى سبحانه ليوم القيامة أن تبدأ أحداثه فإنه بأمر الملك الموكل

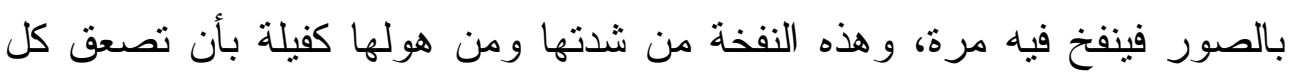
حي موجود في عالم السماوات و الأرض، حتى لا يبقى إلا الملك الديان سبحانه

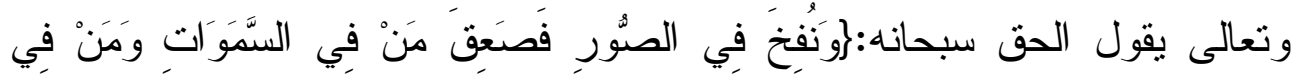

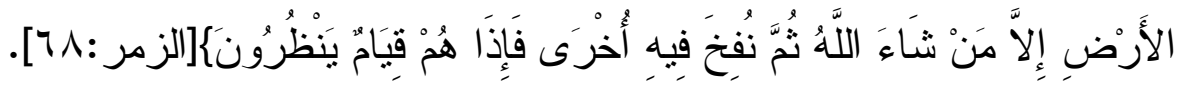
لقد كانت هذه النفخة كفيلة بهلالك كل شيء وفناء كل شيء ولكن هل يعم الفناء كل شيء؟ إن الآية هنا قد بينت بأن الصعق قد شمل كل شيء إلا ما شاء الله،

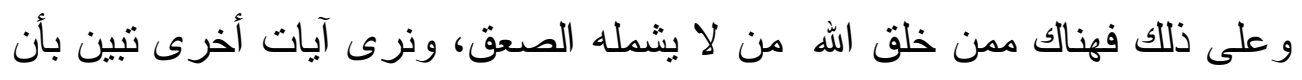

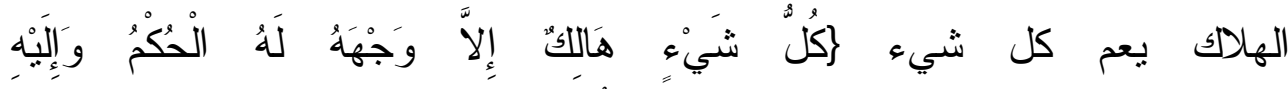

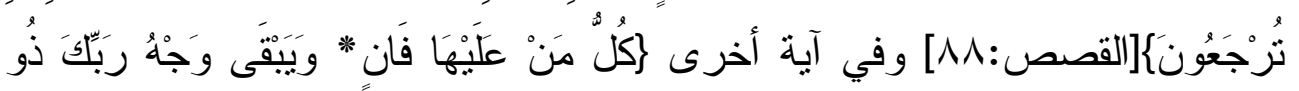

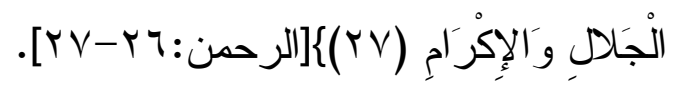

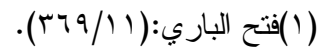

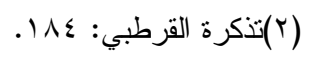

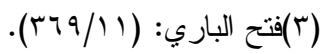


فهل يعم الفناء أرجاء الملكوت كله من الإنس و الجن و الملائكة و السماوات و الأرض، وكل ما خلق الله سبحانه حتى لا يبقى إلا وجه الملك الديان، أم إن هنالك مما خلق الله سبحانه ما لا يشمله الفناء اختلفت آر اء العلماء في ذلك: 1- فذهب ابن حزم إلى أنهم جميع الملائكة، لأن الملائكة في اعتقاده أرواح لا أجساد فيها، فلا يمونون أصلاًًا' أ). و هذا الذي ذهب إليه من أن الملائكة لا يموتون لا يُسلم له، فالملائكة خلق من خلق الله تبارك وتعالى، وهم عبيد مربوبون مقهورون، خلقهم، وهو قادر على إماتتهم وإحيائهم، وقد ثبت في الصحيح عن النبي و احد من الصحابة أنه قال: " إن الله إذا تكلم بالوحي أخذ الملائكة منه منل الغشى"، وفي رواية: " إذا سمعت الملائكة كلامه صعقوا " فأخبر في هذا الحديث أنهم يصعقون صعق الغشي، فإذا جاز عليهم صعق الغشي، جاز عليهم صعق

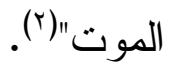

r- وذهب مقاتل وغيره إلى أنهم جبرائيل وميكائيل و إسر افيل وملك الموت(ץ).و أضاف إلبه بعض أهل العلم حملة العرش(ع). وصحة هذا متوقف على أحاديث رووها، وأهل العلم بالحديث لا يصححون منثلها (0). r- وذهب الإمام أحمد بن حنبل رحمه الله إلى أن المر اد بهم الذين في الجنة

$$
\begin{aligned}
& \text { (1) (بقتح الباري: (TV/T) }
\end{aligned}
$$

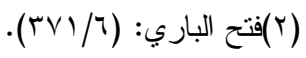

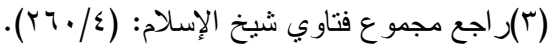

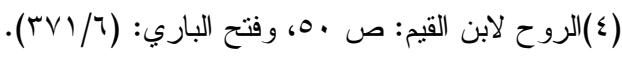

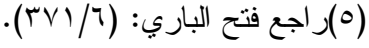


من الحور العين والولدان، وأضاف إليهم أبو إسحاق بن شاقلا من الحنابلة،

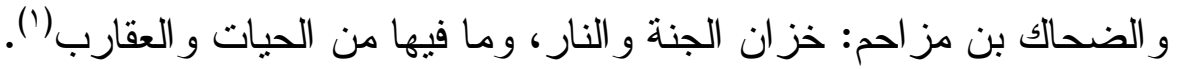
يقول ابن تيمية رحمه الله تعالى: " و أما الاستثناء فهو متتاول لما في الجنة من

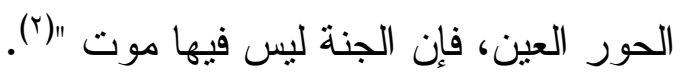
ع - وقد جنح أبو العباس القرطبي صاحب (الدفهم إلى شرح مسلم)) إلى أن المر اد بهم الأمو ات كلهم، لكونهم لا إحساس لهم، فلا يصعقون ("). وما ذهب إليه أبو العباس صحيح إذا فسرنا الصعق بالموت، فإن الإنسان

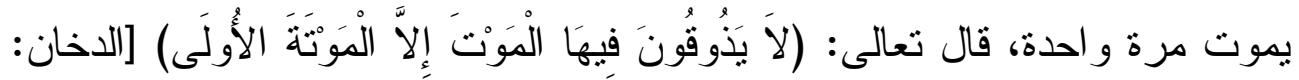

وقد عقد ابن القيم في كتابه: (الروح)" فصلاً بيَّن فيه أن أهل العلم قد اختلفوا في موت الأرواح عند النفخ في الصور موالذي رجحه ابن القيم أن موت الأرواح

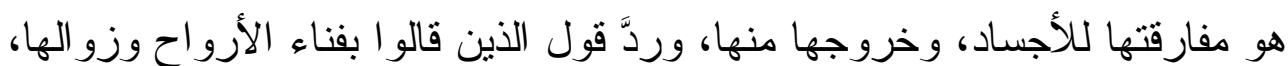

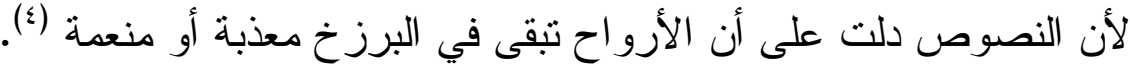
أما إذا فسرنا الصعق بالغشى، فإن الأرواح تصعق بهذا المعنى، ولا تكون

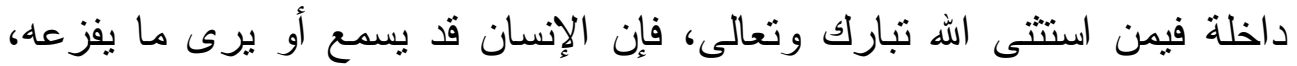

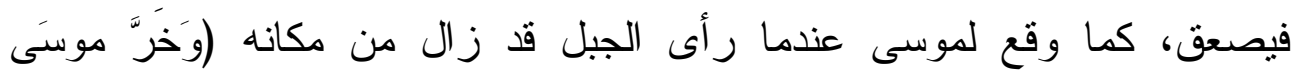

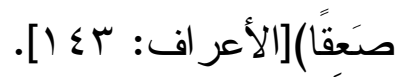
وقد جاء هذا المعنى صريحاً في بعض النصوص، ففي حديث أبي هريرة، عند 
البخاري قال: قال رسول اله ؛

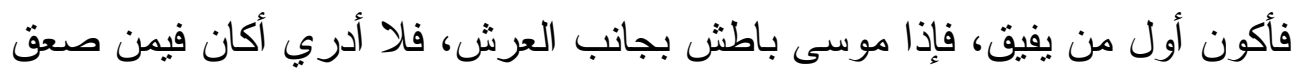

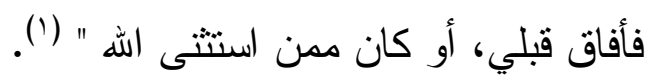

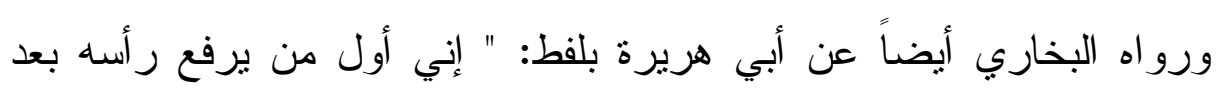

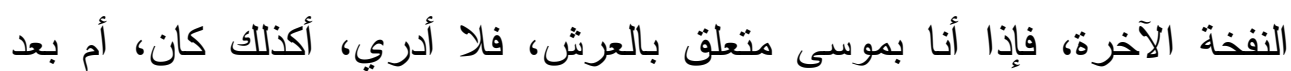
النفخة"(؟)

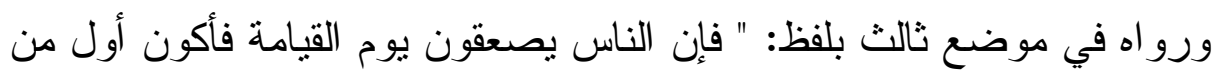
يفيق، فإذا موسى باطش بجانب العرش، فلا أدري أكان فيمن أفاق قبلي، أو كان بهان

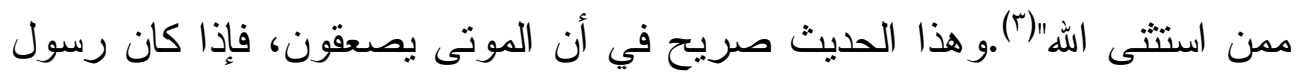

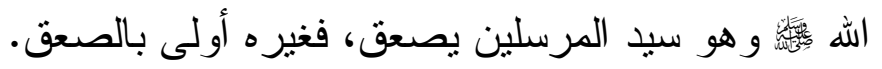
وقد ذهب بعض أهل العلم إلى أن الذي يصعق صعق غشى هم الشهداء دون

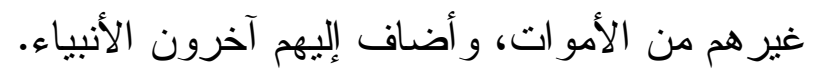

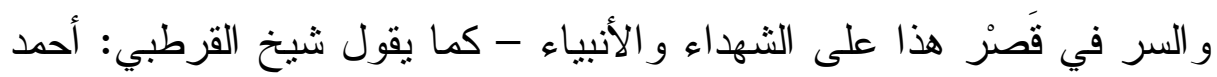
بن عمر -- " أن الثهداء بعد قتلهم وموتهم أحياء عند ربهم يرزقون فرحين مستشرين، و هذه صفة الأحياء في الانبا، و إذا كان هذا حال الثهداء كان الأنبياء

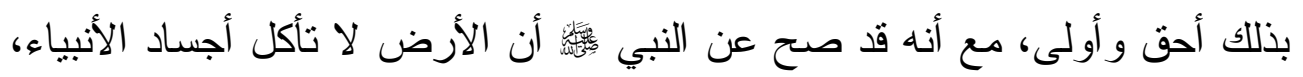

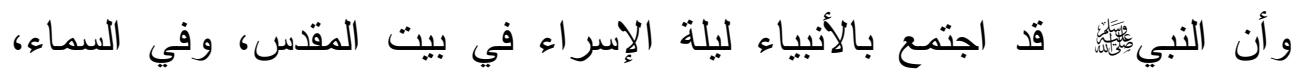

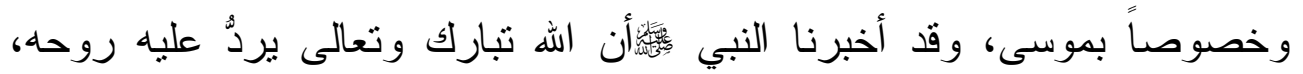

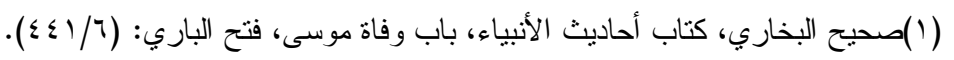

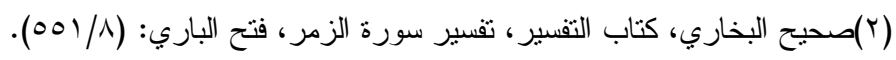

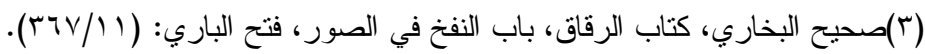

$$
\begin{aligned}
& -9 \varepsilon-
\end{aligned}
$$


حتى يرد السلام على كل من يسلم عليه، إلى غير ذللك مما يحصل من جملته القطع

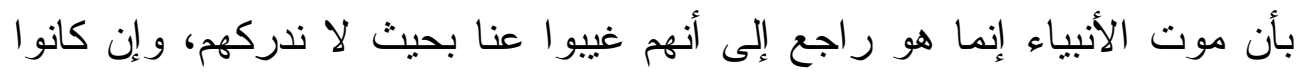

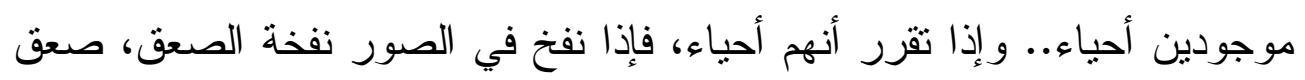
كل من في السماو ات ومن في الأرض، إلا من شاء الله " (').

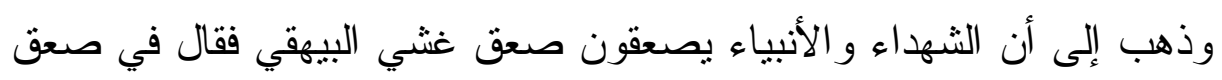

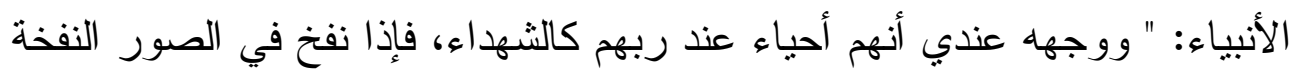

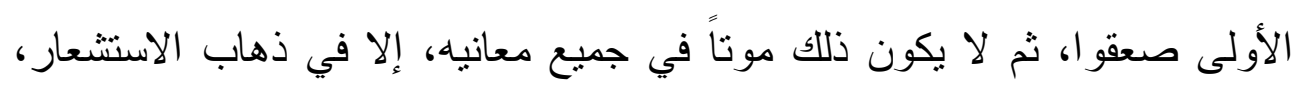
وقد جوز النبي

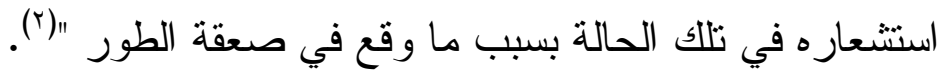
وبناء على هذا الفقه يكون الأنبياء و الثهداء من الذين يصعقون، و لا يكونون

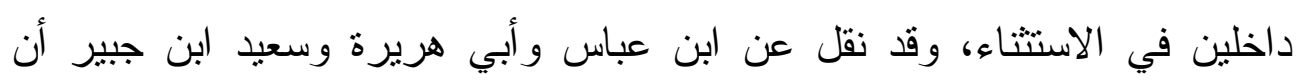

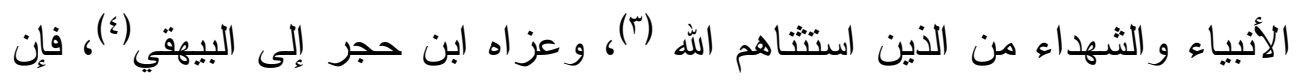

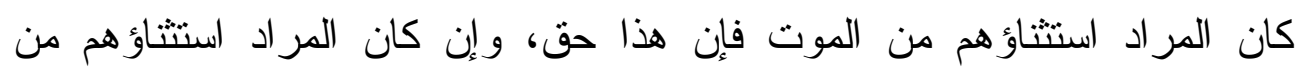
الصعق الذي يصيب الأموات كما دل عليه حديث موسى فالأمر ليس كذلك. وذهب بعض أهل العلم إلى أن الأولى بالمسلم التوقف في تعيين الذنين استثناهم

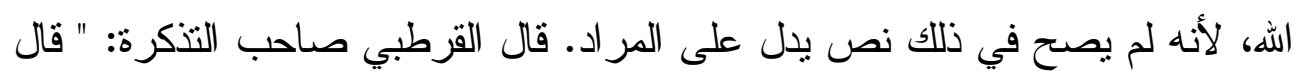

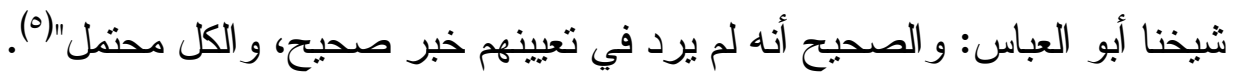


القيامة الكبرى (مشاهد ووقائع، دروس وعبر)

وقال ابن تيمية: " وأما الاستثناء فهو متتاول لمن في الجنة من الحور العين، فإن الجنة ليس فيها موت، ومتتاول لغيرهم، و لا يمكن الجزم بكل ما استثناه الله،

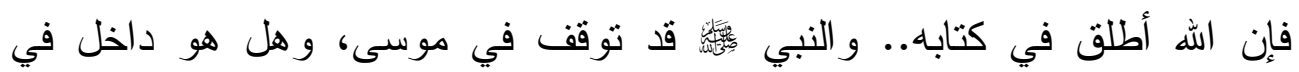
الاستثناء فيمن استثناه اله أم لا؟ كابه

فإذا كان النبي

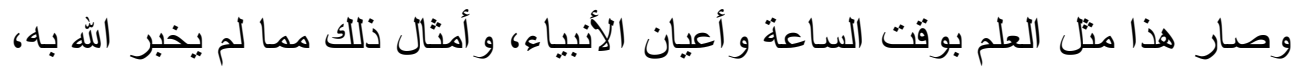
و هذا العلم لا ينال إلا بالخبر ، و الله أعلم "(1).

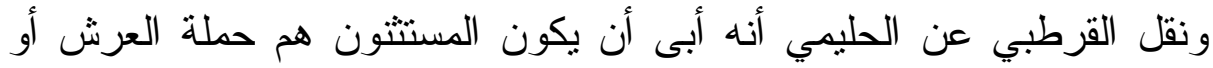

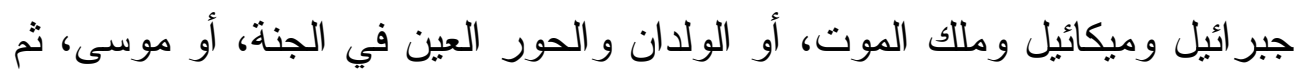
بيَّن سر إنكاره لهذا فقال: " أما الأول، فإن حملة العرش ليسو امن سكان السماوات و لا الأرض، لأن العرش فوق السماو ات كلها، فكيف يكون حملته في السماو ات. وأما جبر ائيل وميكائيل وملك الموت فمن الصافين المسبحين حول العرش، و إذا كان العرش فوق السماو ات، لم يكن الاصطفاف حوله في السماو ات. وكذلك

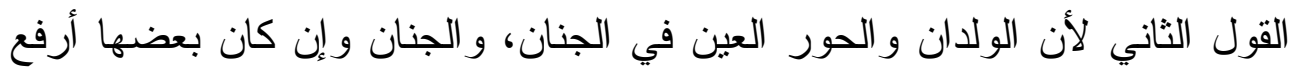

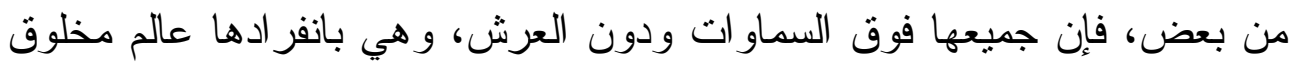

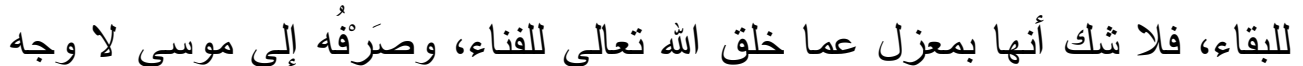
له، لأنه قد مات بالحقيقة، فلا يموت عند نفخ الصور ثانية "(؟). ورد قول الذين قالوا المستثنون هم الأموات: " لأن الاستثناء إنما يكون لمن

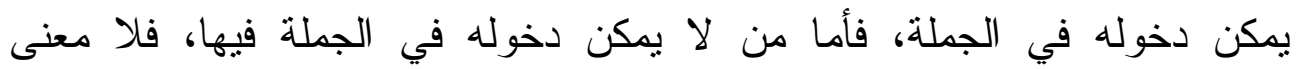


لاستثنائه منها، و الذين ماتوا قبل نفخ الصور ليسوا بفرض أن يصعقو ا فلا وجه

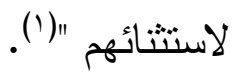

و الذي اختاره أن الغشية التي تصيب موسى ليست هي الصعقة التي تهلك الناس وتميتهم، وإنما هي صعقة تصيب الناس في الموقف بعد البعث، على أحد الاحتمالين عنده.

ونقل القرطبي عن شيخه أحمد بن عمر أنه ذهب هذا المذهب، قال القرطبي: "

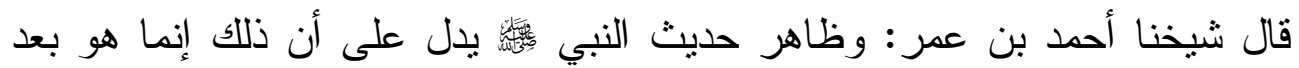
النفخة الثنانية نفخة البعث، ونص القرآن بقتضي أن ذلك الاستثناء إنما هو بعد نفخة

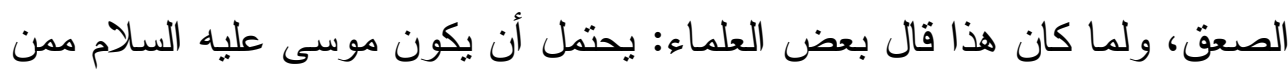
لم يمت من الأنبياء، وهذا باطل، بما تقدم من ذكر موته. وقال القاضي عياض: يحتمل أن يكون المراد بهذه صعقة فزع بعد النشر ، حين تتشق السماو ات و الأرض فنستقل الأحاديث و الآيات و الله أعلم "(؟). وقد جزم ابن القيم رحمه الله تعالى بأن الصعقة التي تحدّث عنها الرسول

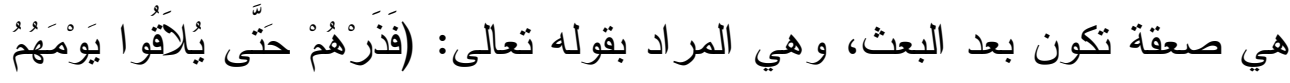

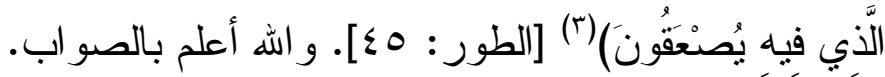
وبعد هذا العرض لآر اء العلماء في قضية الصعق لا يبقى إلا أن نقول اله أعلم بالصو اب في ذللك وذللك لأمور منها: -أن آيات القرآن التي تتاولت هذه القضية لم تأت لنا بخبر قاطع يمكننا من 
خلاله الجزم بحقيقة ما يحدث في هذا الموقف فآية سورة الزمر بينت بأن الصعق

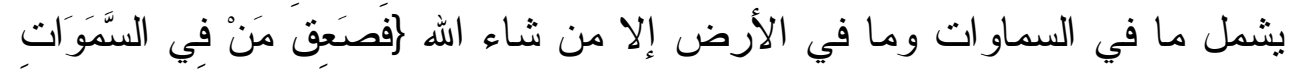

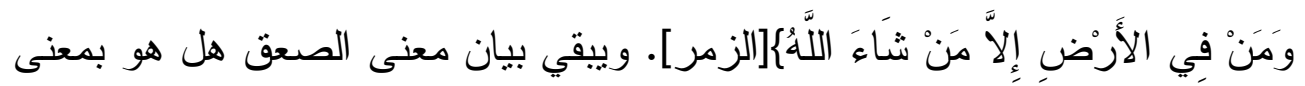

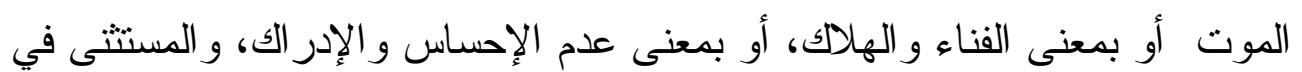

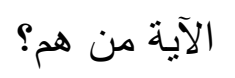

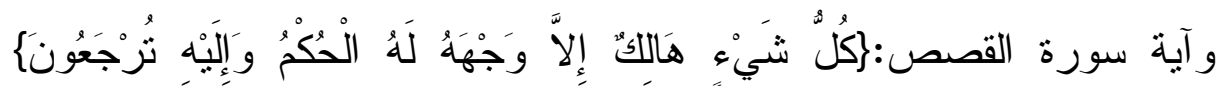

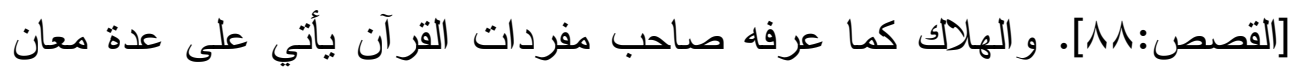

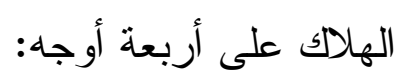

- افتقاد الثيء عناك، وهو عند غيرك موجود كقوله تعالى: (هلك عني سلطانيه\{[(الحاقة/9r].

- وهلاك الثيء باستحالة وفساد كقوله: (ويهلاك الحرث و النسل\{[البقرة/ ه بـ] ويقال: هلاك الطعام. و الثالث: الموت كقوله: [إن امرؤ هلكي\{[النساء/VY] وقال تعالى مخبرا عن

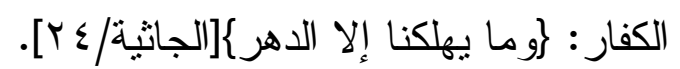
و الر ابع: بطلان الثيء من العالم و عدمه رأسا، وذلك المسمى فناء المشار إليه بقوله: [كل شيء هالك إلا وجهه\{[القصص/11] ويقال للعذاب و الخوف و الفقر : الهالك، (') (1)

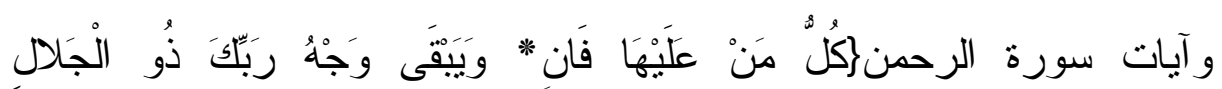

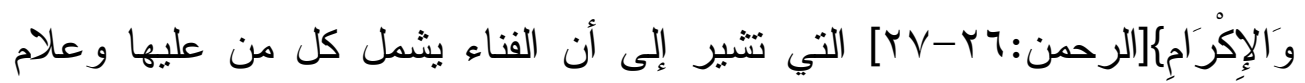
يعود الضمير في قوله عليها؟ هل يعود إلى الأرض التي نحيا عليها فكل من عليها (1) مفردات ألفاظ القر آن للراغب الأصفهاني مادة: هلك. 
القيامة الكبرى (مشاهد ووقائع، دروس وعبر)

يفنى و لا تفنى هي بحد ذاتها كما لا يدخل في الحكم السماو ات وما فيها. وبناءً على ذلك فإنه لا يبقى أمامنا إلا أن نقول الله أعلم بحقيقة ما يحدث حينئذ

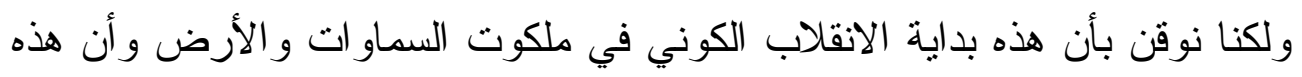

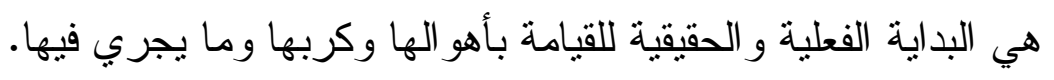
في أي يوم تقوم الساعة

إذا كان الحق سبحانه قد أخفي عن الخلق جميعاً متى تقوم الساعة فلقد أنبأنا رسول اله دأس بيوم قيامها ألا وهو يوم الجمعة ففي صحيح مسلم عن أبي هريرة

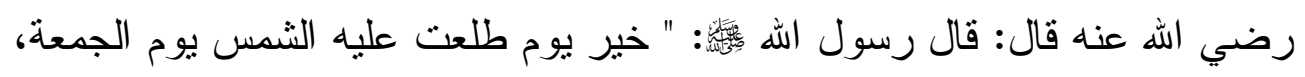

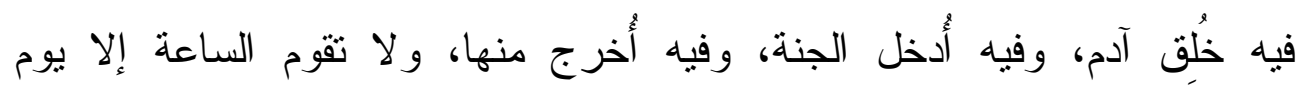

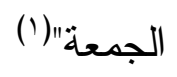

وفي حديث آخر أخبر الرسول دأس أن الساعة تقوم في يوم الجمعة، وفيها يُعتث العباد أيضاً، فعن أوس بن أوس قال: قال رسول اله الهي

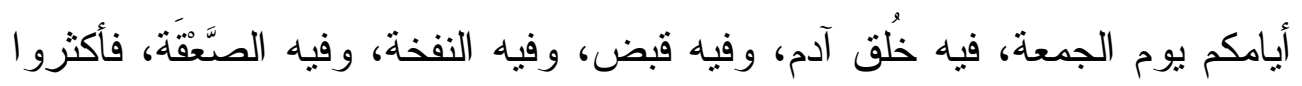

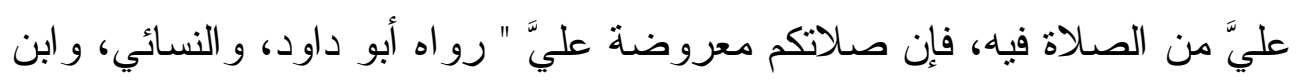

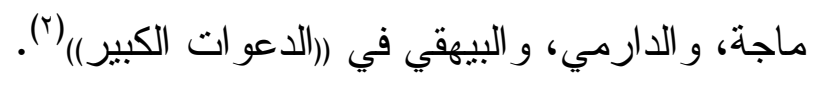

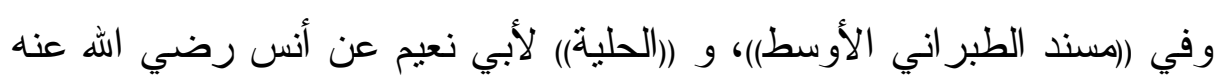

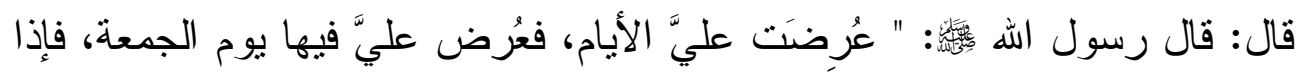

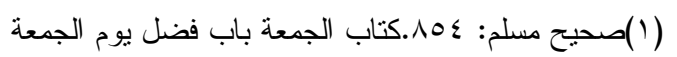

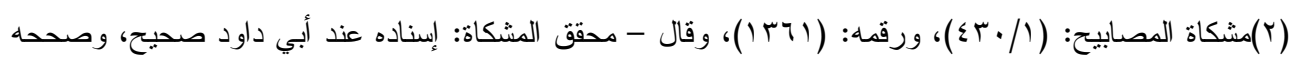
جماعة. 
القيامة الكبرى (مشاهد ووقائع، دروس وعبر)

هي كمر آة بيضاء في وسطها نكتة سوداء، فقلت: ما هذه؟ قيل: الساعة"((). ولما كانت الساعة تقع في هذا اليوم فإن المخلوقات في كل يوم جمعة تكون مشفقةً خائفةً إلا الإنس والجن، ففي موطأ الإمام مالك، وسنن أبي داود، وسنن الترمذي و النسائي، ومسند أحمد عن أبي هريرة رضي الله عنه قال: قال رسول الله

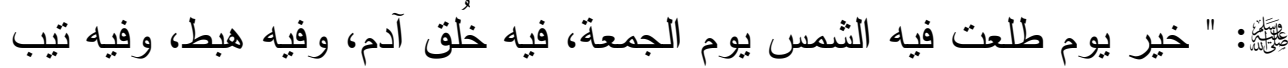
عليه، وفيه مات، وفيه تقوم الساعة، وما من دابة إلا وهي مصيخة(؟)، يوم الجمعة من حين تصبح حتى تطلع الثمس، شفقاً من الساعة، إلا الجن و الإنس"(").

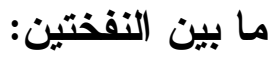

تُرى كم من الوقت يمر بين النفختين؟ وكيف يكون حال العباد ساعتها وما هي

الأمور التي تجري حينئ؟

من خلال آيات القرآن ومن خلال أحاديث رسول اله

عدد من الحقائق تحدث بين النفختين:

- تمر مدة طويلة من الزمن لا يعلم مقدار ها على وجه الدقة إلا الله سبحانه

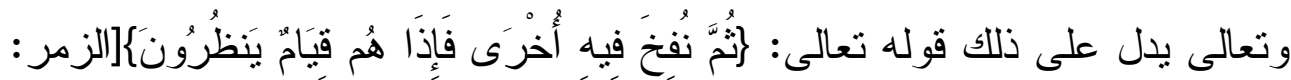
14]. وثم حرف عطف يفيد الترتيب و التراخي، و التزاخي هنا في الزمن ودلالة النص:أنه ستمر فترة طويلة من الزمن لا يعلم مقدارها إلا الحق سبحانه جاء الحديث مبيناً أنها أربعون ففي صحيح البخاري ومسلم عن أبي هريرة رضي الله

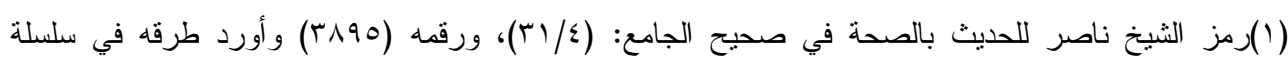

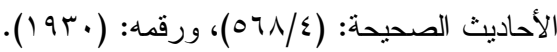

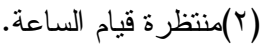

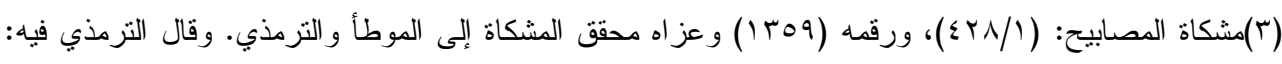


القيامة الكبرى (مشاهد ووقائع، دروس وعبر)

عنه عن النبي

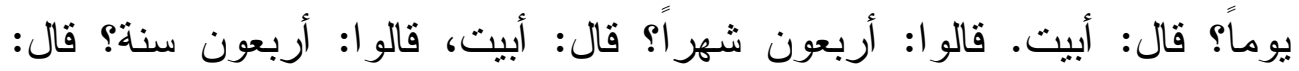
أبيت (') (1) (2)

إنها أربعون ولكن هل تُراها أربعون يوماًٌ أو أربعون شهر أٌ أو أربعون سنة؟ أو أربعون قرناً من الزمان علم ذلك عند الله سبحانه وتعالى، وكما كان أمر قيام الساعة غيب لا يعلمه إلا الحق سبحانه، فكذلك ما بين النفختين مدة من الزمن لا

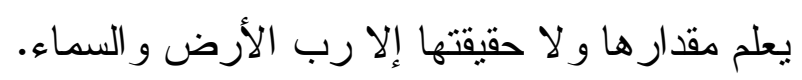

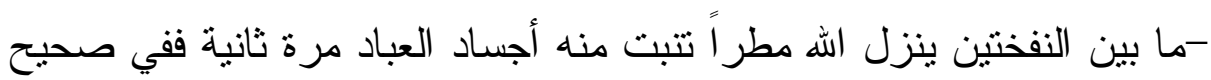
مسلم عن عبد الله بن عمرو بن العاص أنه سمع رسول اله \$

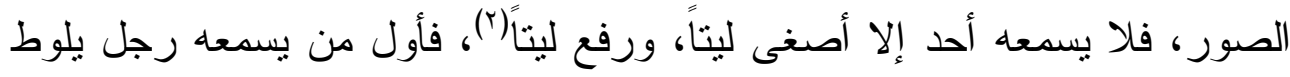

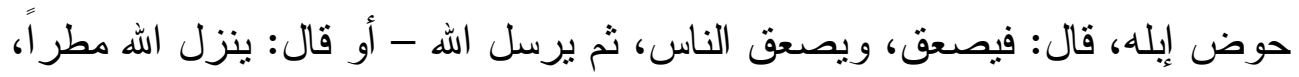

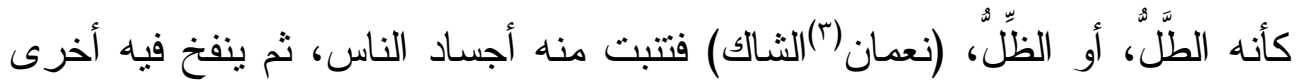

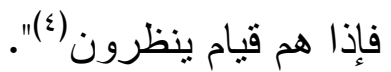

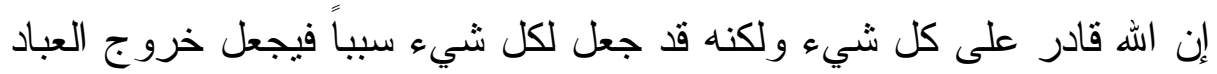

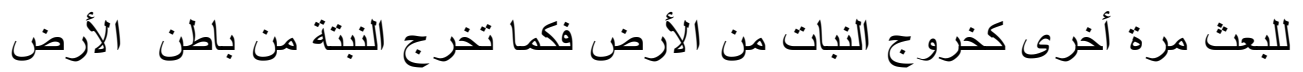

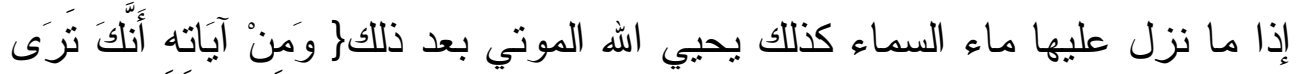

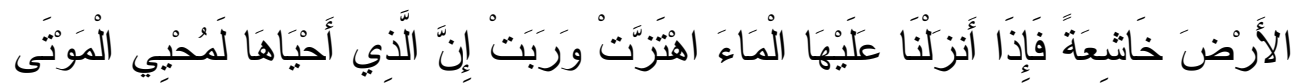

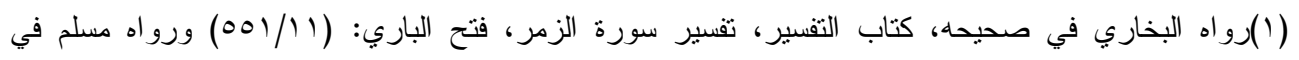

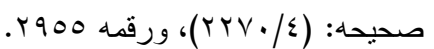
(r) (ب) الليت: صفحة العنق، و إصغاؤه: إملالته.

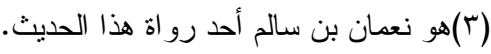

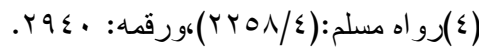


القيامة الكبرى (مشاهد ووقائع، دروس وعبر)

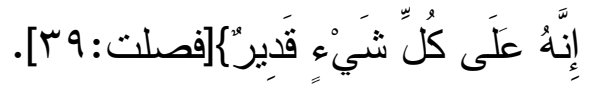

وكما تكون البذرة أصلاً لثجرة يانعة كذلك يترك الحق سبحانه بقية من البشر

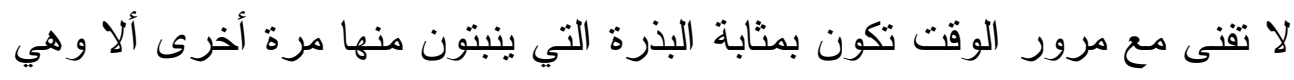

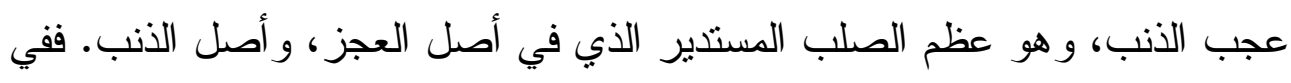

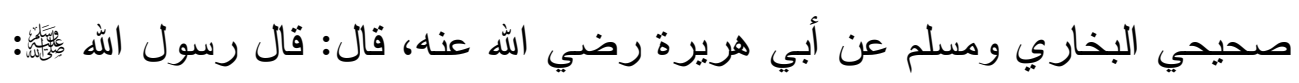

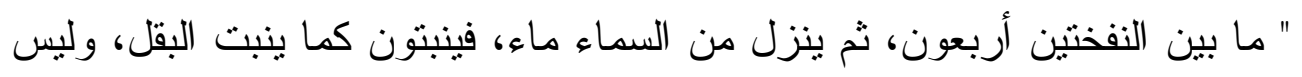
في الإنسان شيء إلا بلّي، إلا عظم واحد، وهو عجب لبن الذنب منه يركب الخلق يوم القيامة "(')

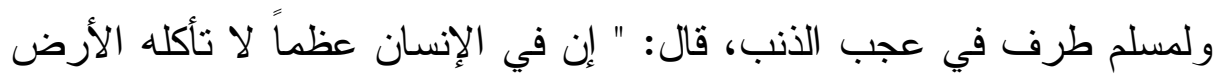

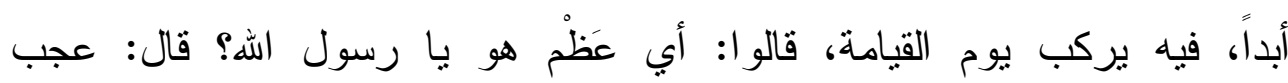

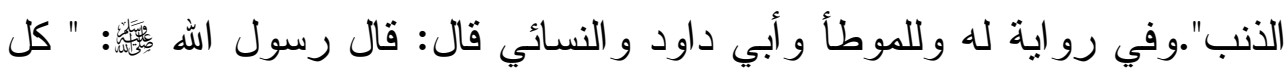

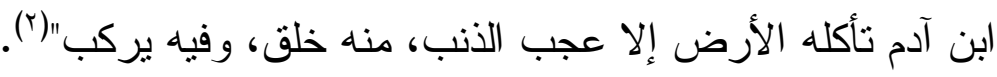

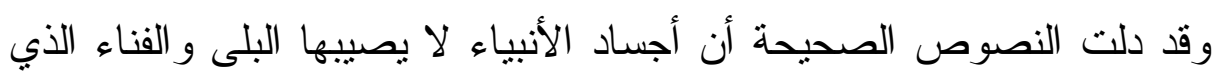

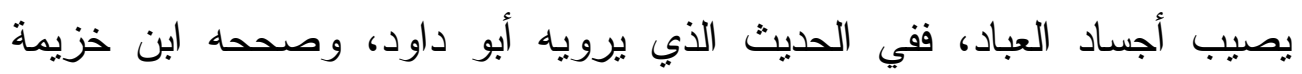
و غيره: " إن الله حرم على الأرض أن تأكل أجساد الأنبياء"(").

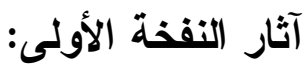

لقد أر اد الحق سبحانه أن تكون النفخة الأولى إيذاناً بنهاية الدنيا وبداية الآخرة

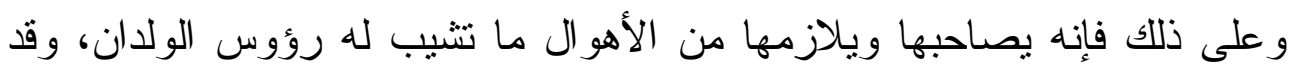

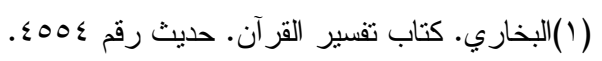

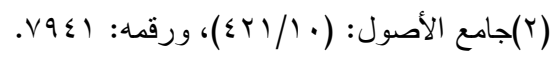

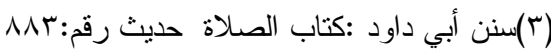


القيامة الكبرى (مشاهد ووقائع، دروس وعبر)

بينت آيات القرآن ذلك في أكثر من موضع في كتاب الله فهي تحدثنا بأن الاضطر اب بعم أرجاء الكون بأسره سماءه و أرضه، جباله وبحاره، كو اكبه و أفلاكه ونجومه ومن خلا كتاب الله سبحانه وبيان رسول الله و اضحة لما يحدث ساعتئذ وبيان ذلك في النقاط التالية:

\section{-اختلال نظام الكون و انفراط عقده}

لقد خلق الحق سبحانه ملكوت السماو ات والأرض بناءً محكماً ونظاماً بديعاً، جعل من دقة صنعه و عظيم خلقه دليلاً وبر هاناً على عظيم قدرته وبالغ عظمتها، وجاءت آيات كثيرة من كتاب الله مؤكدة هذا ومبينة ذلك ومتحدية للمخاطبين جميعاً

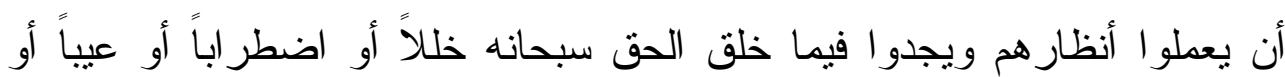

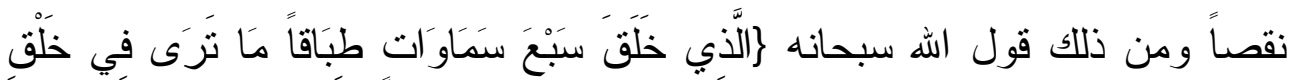

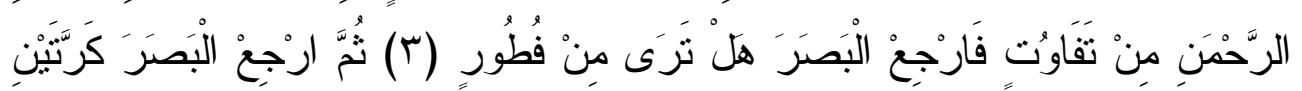

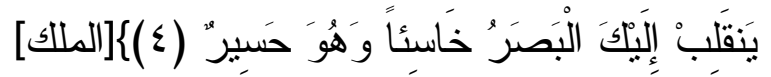

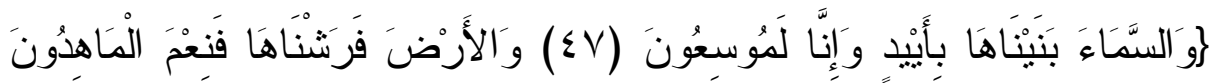

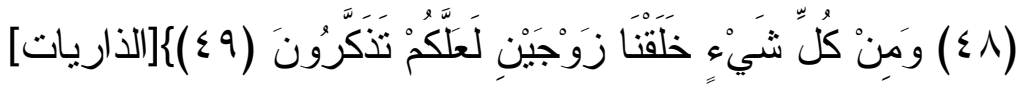
هذا البناء المحكم وصنع الله الذي اتقن فيه كل شيء يظل على متانته وعلى

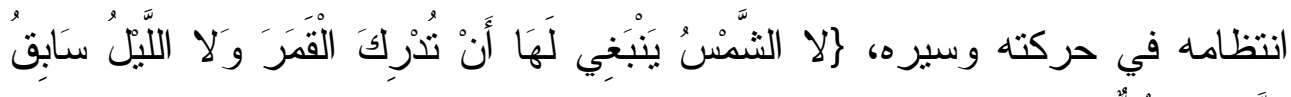

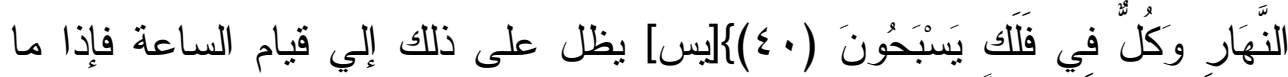
جاءت يضطرب نظام الكون كله وتختل حركته وينفرط عقد نجومه ونتهاوى أفلاكه

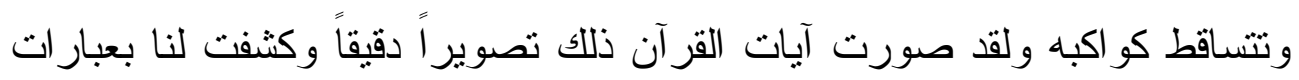
محكمة مقدار الخلل والاضطراب الذي يصيب كل شيء في ملكوت السماوات

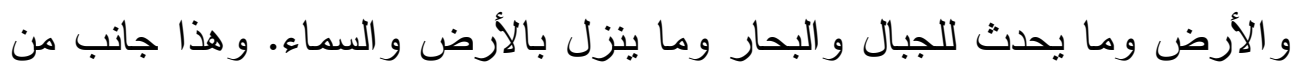


الآيات التي تبين لنا ذلك يقول الحق سبحانه:

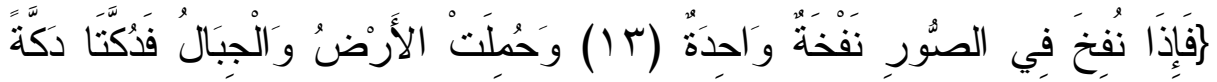

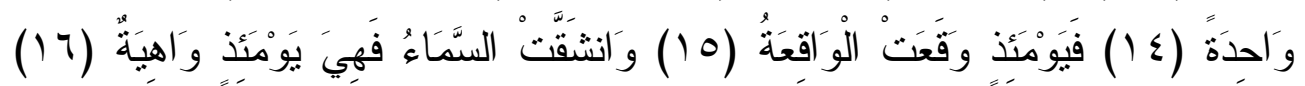

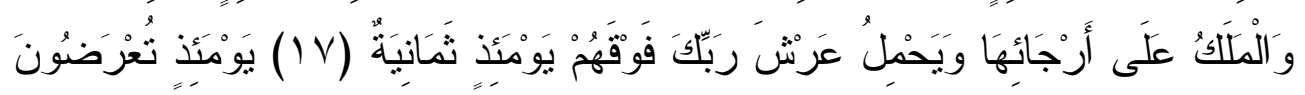

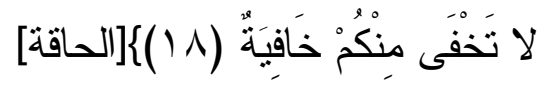

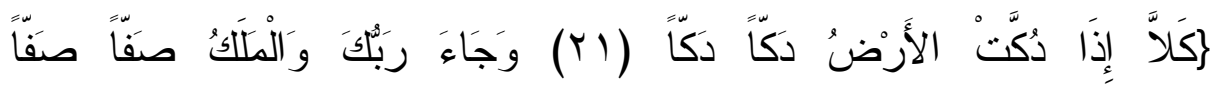

[إن

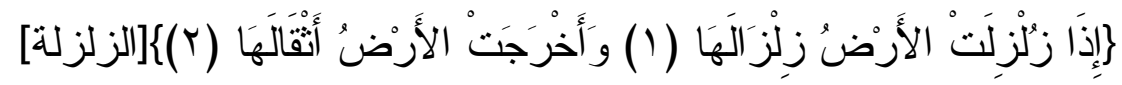

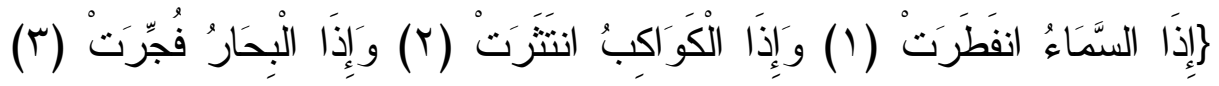

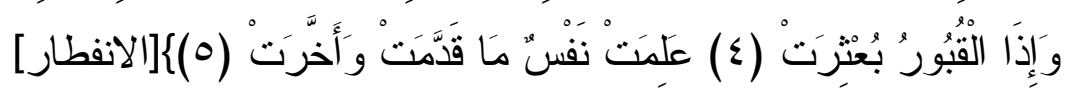

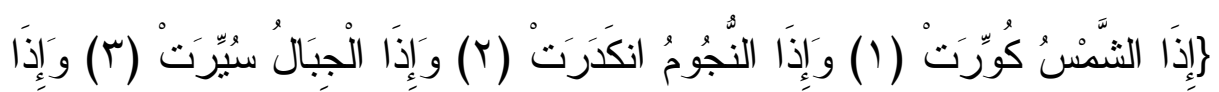

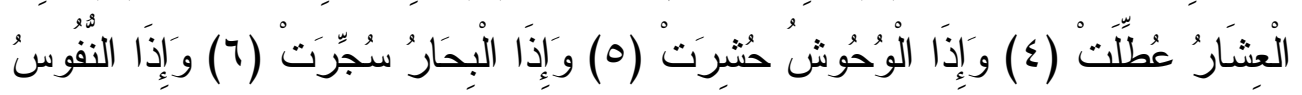

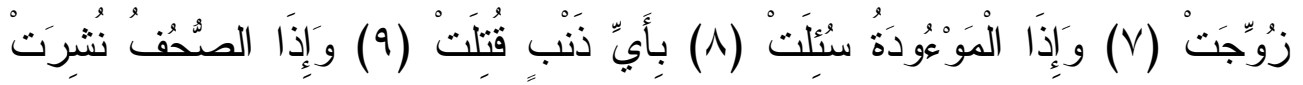

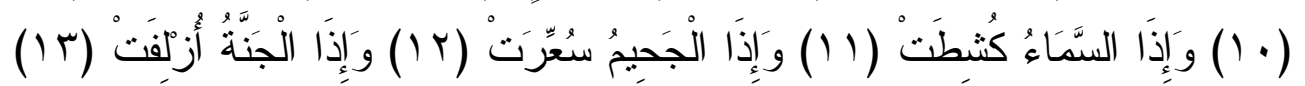

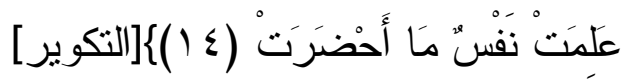

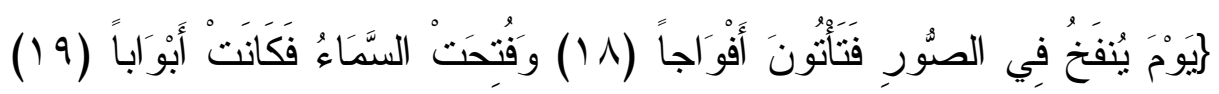

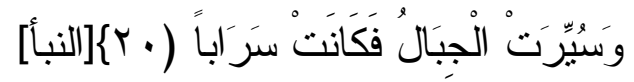
إن الحق سبحانه قد صور أمر يوم القيامة وأحداثه تصوير اً تتبيب من أجله

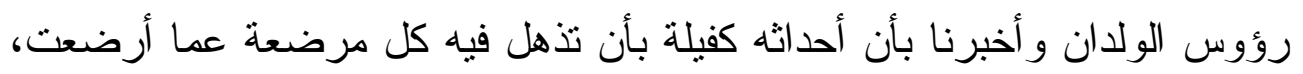
و وان نترك الناس سكارى وما هم بسكارى حيث يقول سبحانه:

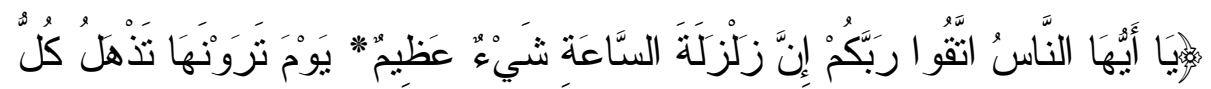




\section{القيامة الكبرى (مشاهد ووقائع، دروس وعبر)}

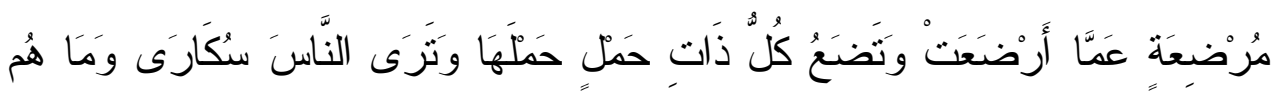

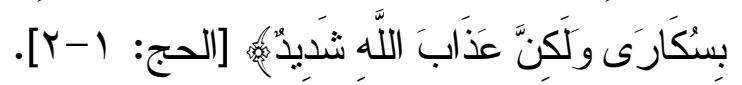

و إن الانقلاب يعم كل شيء في ملكوت السموات والأرض ويشمل الأجرام السماوية وكل ما في الكون، فالثمس التي تغمر هذه الحياة بالضياء، تجمع وتكور

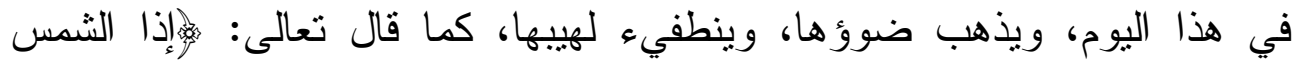

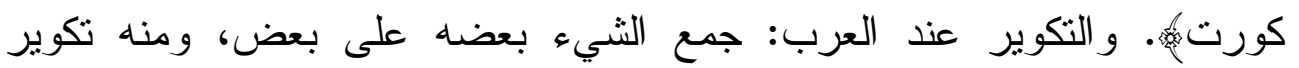

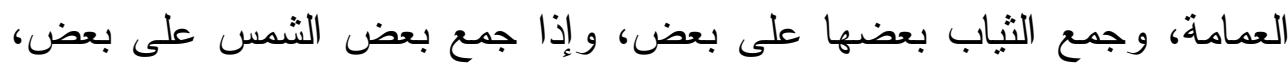
ذهب ضوؤها ورمى بها.

أما القمر الذي نراه في أول الثهر هلالاً ثم يتكامل ويتتامى حنى بصبح بدراً

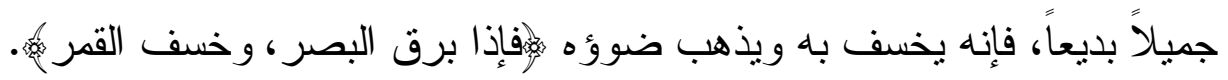
أما تلك النجوم المتتاثرة في القبة السماوية الزرقاء، فإن عقدها ينفرط فتنتاثر

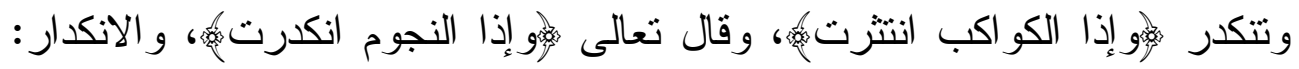
الانتتار ، وأصله في لغة العرب: الانصباب.

أما البحار التي تغطي الجزء الأعظم من هذه الأرض وتعيش في باطنها

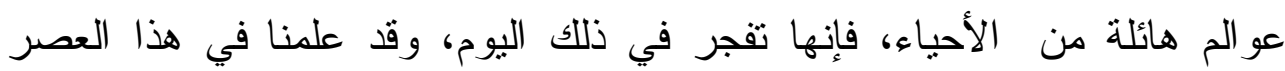

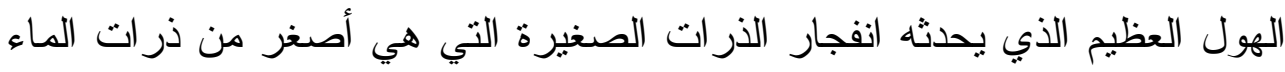
فكيف إذا فجرت ذرات المياه في هذه البحار العظيمة، عند ذلك تسجر البحار، وتتتعل نار ا، ولك أن تتصور هذه البحار العظيمة الهائلة وقد أصبحت مادة قابلة للإثتتعال، كيف يكون منظرها، اللهب يرتفع منها إلى أجواز الفضاء، قال نعالى

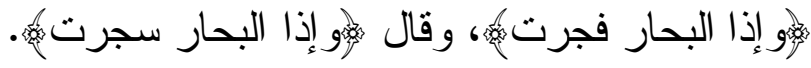
وقد ذهب المفسرون قديما إلى أن المر اد بتفجير البحار، تتشق جو انبها وزوال 
القيامة الكبرى (مشاهد ووقائع، دروس وعبر)

ما بينها من الحو اجز واختلاط الماء العذب بالماء المالح، حتى تصير بحر ا واحدا، وما ذكرناه أقرب وأوضح، فان التفجير بالمعنى الذي ذكرناه مناسب للتسجير و الله

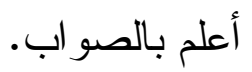

\section{رسم صورة متكاملة للأحداث من خلال عبار ات المفسرين}

لقد نزلت آيات القرآن الكريم مفصلة الحديث عن الساعة و أهو الها وشدة الفزع و الكرب فيها، وفي هذا المبحث سنتكفي بجانب من الآيات التي تبين ذلك وتتاول المفسرين لها:

\section{تصوير صاحب الظلال للأحداث:}

لقد صور صاحب الظلال هذا الموقف تصويراً دقيقاً في غاية الروعة و الجمال فيقول: فإذا نفخ في الصور نفخة واحدة، فتبع هذه النفخة تلك الحركة

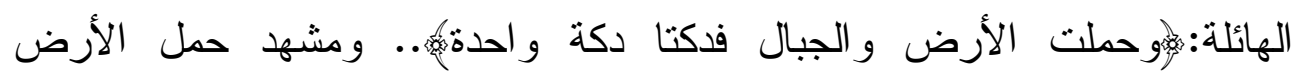

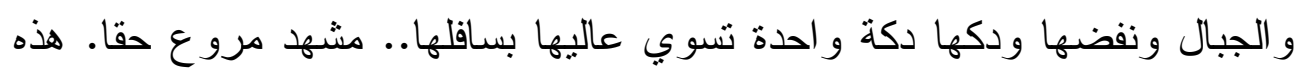

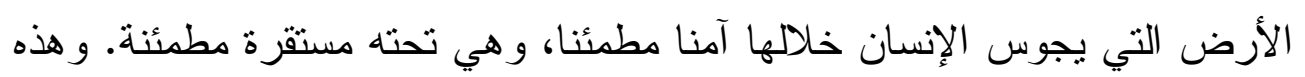

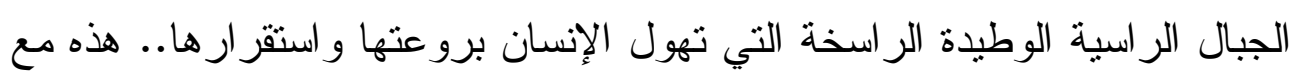

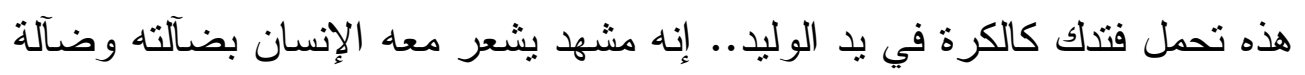
عالمه إلى جانب هذه القدرة القادرة، في ذللك اليوم العظيم.. فإذا وقع هذا. إذا نفخ في الصور نفخة واحدة، وحملت الأرض و الجبال فدكتا

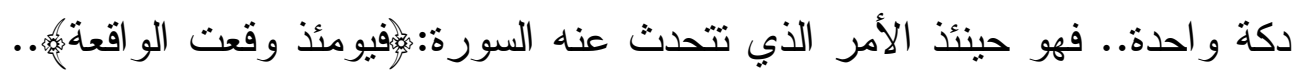

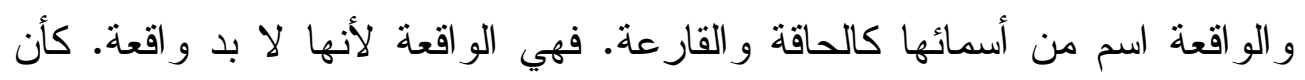
طبيعتها وحقيقتها الدائمة أن تكون واقعة ! وهو اسم ذو إيحاء معين وهو إيحاء مقصود في صدد الارتياب فيها و التكذيب ! 
القيامة الكبرى (مشاهد ووقائع، دروس وعبر)

و لا يقتصر الهول على حمل الأرض و الجبال ودكها دكة واحدة، فالسماء في

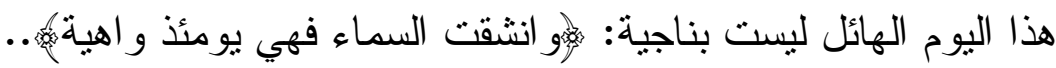

ونحن لا ندري على وجه التحقيق ما السماء المقصودة بهذا اللفظ في القرآن.

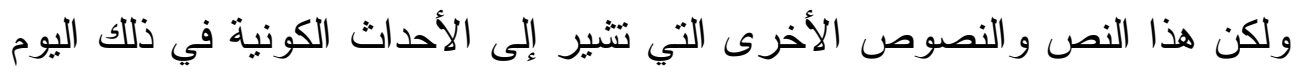

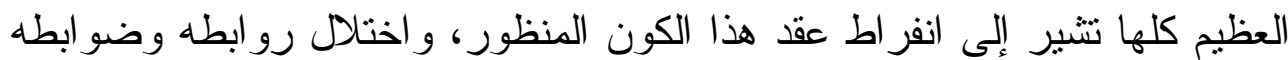
التي تمسك به في هذا النظام البديع الدقيق، وتتاثز أجزائه بعد انفلاتها من قيد إندان

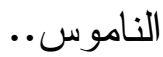

ولعله من المصادفات الغريبة أن ينتبأ الآن علماء الفلك بشيء يشبه هذا تكون فيه نهاية العالم، استتباطا من ملاحظتهم العلمية البحتة، وحسب القليل الذي عرفوه من طبيعة هذا الكون وقصته كما افترضوها..

فأما نحن فنكاد نشهر هذه المشاهد المذهلة، من خلال النصوص القرآنية الجازمة ؛ وهي نصوص مجملة توحي بشيء عام ؛ ونحن نقف عند إيحاء هذه

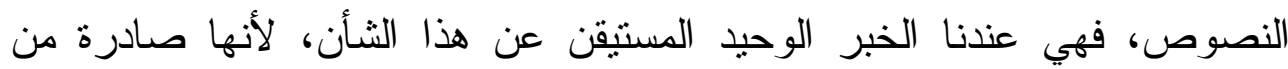

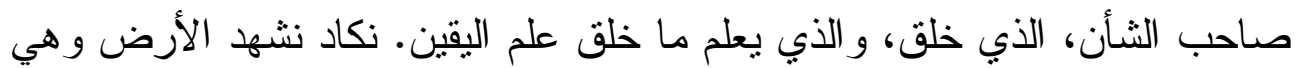

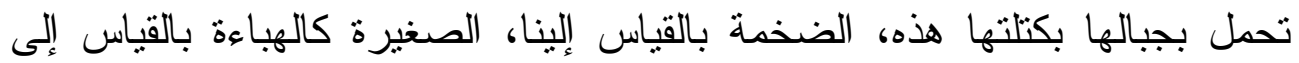
الكون، فتلك دكة واحدة ؛ ونكاد نشهد السماء وهي مشققة واهية و الكو اكب وهي متتاثرة منكدرة.. كل ذللك من خلا النصوص القر آنية الحية، المشخصة المشاهد بكامل قوتها كأنها حاضرة.

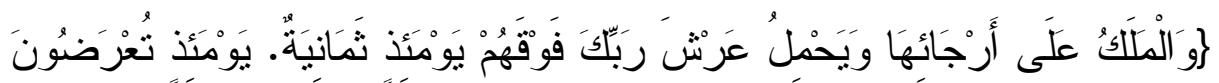

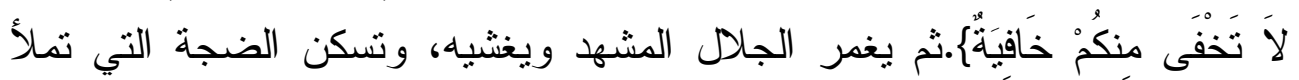

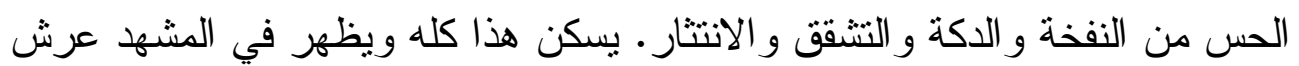


القيامة الكبرى (مشاهد ووقائع، دروس وعبر)

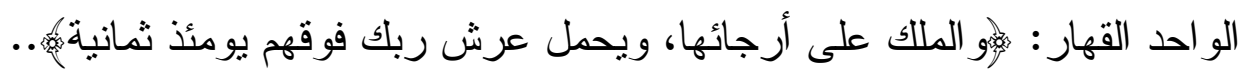
و الملائكة على أرجاء هذه السماء المنشقة و أطر افها، و العرش فوقهم يحمله ثمانية.. ثمانية أملاك أو ثمانية صفوف منها، أو ثمانية طبقات من طبقاتهم، أو ثمانية مما بعلم اله. لا ندري نحن من هم و لا ما هم. كما لا ندري نحن ما العرش ؟ و لا كيف يحمل ؟ ونخلص من كل هذه الغيييات التي لا علم لنا بها، ولم يكلفنا اله من علمها إلا ما قص علينا. نخلص من مفردات هذه الغييات إلى الظل الجليل الذي تخلعه على الموقف. وهو المطلوب منا أن تستشعره ضمائرنا. وهو المقصود الديا.

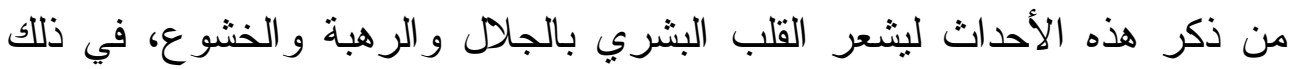
اليوم العظيم، وفي ذلك الموقف الجليل:

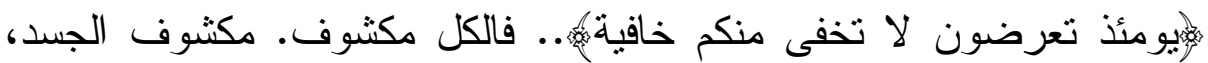
مكثوف النفس، مكثوف الضمير ، مكثوف العمل، مكثوف المصير • وتسقط جميع

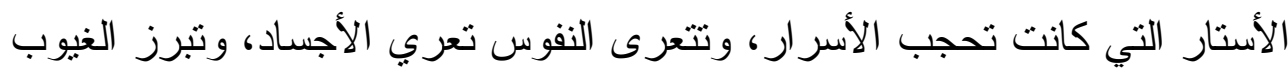
بروز الثهود.. ويتجرد الإنسان من حيطته ومن مكره ومن تدبيره ومن شعوره، ويفتضح منه ما كان حريصا على أن يستره حتى عن نفسه ! وما أقسى الفضيحة

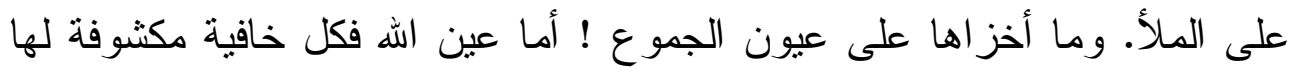
في كل آن. ولكن لعل الإنسان لا يشعر بهذا حق الثشعور، وهو مخدوع بستور

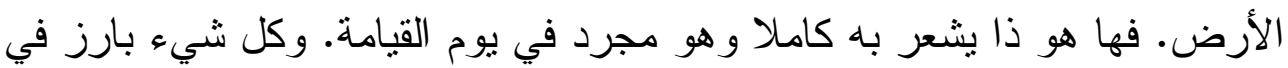

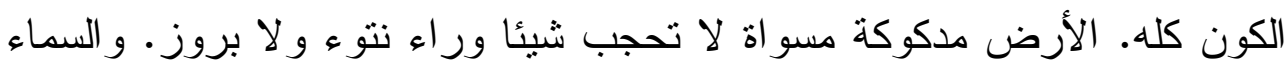

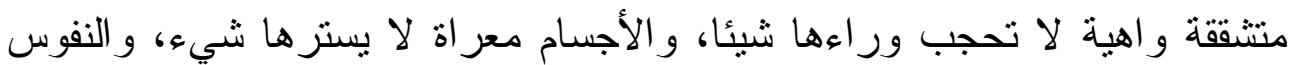
كنللك مكثوفة ليس من دونها ستر وليس فيها سر ! ألا إنه لأمر عصيب. أعصب من دك الأرض و الجبال، وأثند من تثقق السماء 
القيامة الكبرى (مشاهد ووقائع، دروس وعبر)

! وقوف الإنسان عريان الجسد، عريان النفس، عريان المشاعر، عريان التاريخ،

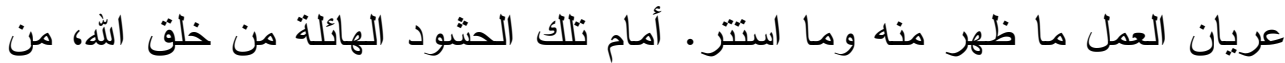
الإنس و الجن و الملائكة، وتحت جلال الله وعرشه المرفوع فوق الجميع.. وإن طبيعة الإنسان لمعقدة شديدة التعقيد ؛ ففي نفسه منحنيات شتى ودروب، تتخفى فيها نفسه وتتكسس بمشاعرها ونزو اتها وهفو اتها وخواطرها و ؤسرارها وخصوصياتها. و إن الإنسان ليصنع أثند مما تصنعه القوقعة الرخوة الهلامية حين تتعرض لوخزة إبرة، فتتطوي سريعا، وتتكش داخل القوقعة، وتغلق على نفسها

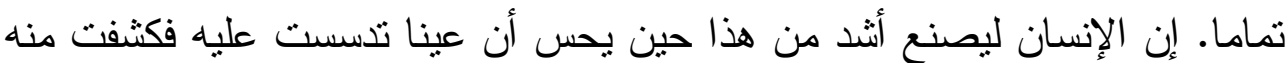

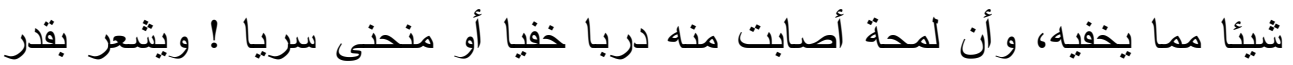
عنيف من الألم الواخز حين يطلع عليه أحد في خلوة من خلو اته الثعورية.. فكيف بهذا المخلوق وهو عريان. عريان حقا. عريان الجسد والقلب و الثعور و النية و الضمير • عريان من كل ساتر . عريان... كيف به وهو كذلك تحت عرش

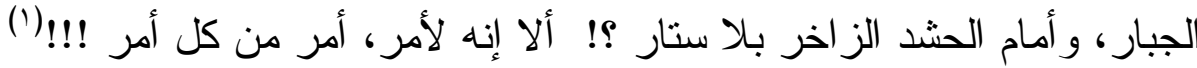

\section{تصوير القرطبي لأهو ال يوم القيامة}

قال القرطبي: " روى الترمذي عن ابن عمر رضي الله عنهما قال: قال رسول الله 1]، (إذا السماء انفطرت) [الانفطار: 1]]، (إذا السماء انشقت) [الانشقاق: 1].قال:

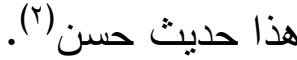

و إنما كانت هذه السور الثلاث أخص بالقيامة، لما فيها من انثقاق السماء 
القيامة الكبرى (مشاهد ووقائع، دروس وعبر)

و انفطارها، وتكور شمسها و انكدار نجومها، وتتاثز كواكبها، إلى غير ذلك من

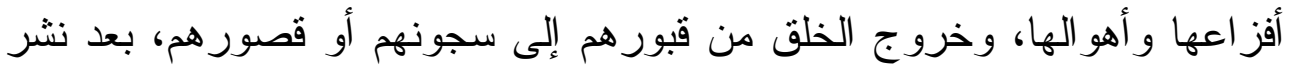

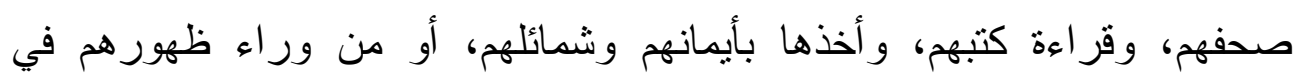

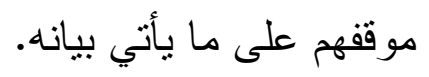

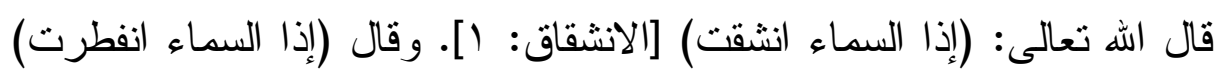

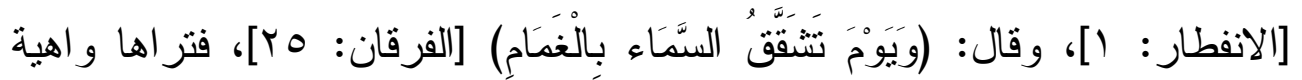

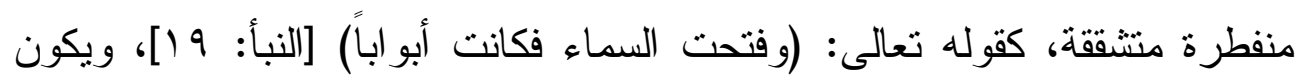

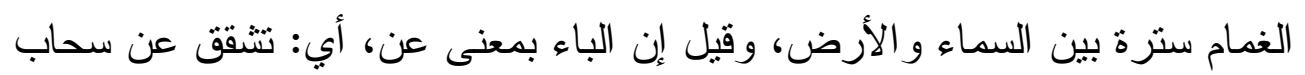

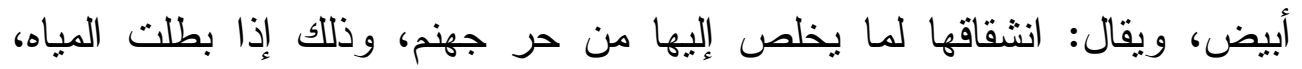

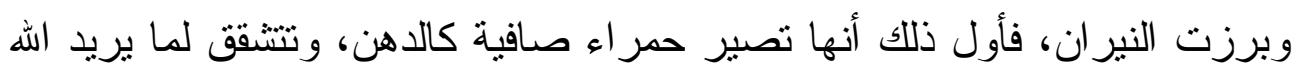

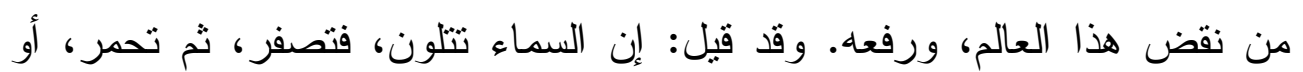

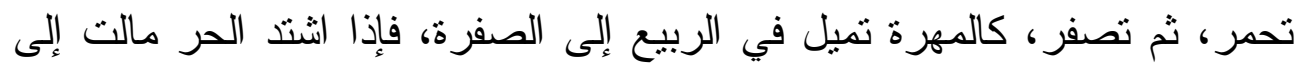
الحمرة، ثم إلى الغبرة، قاله الحليمي.

وقوله تعالى: (إذا الثمس كورت) [التكوير: 1]، قال ابن عباس رضي الله عنه: تكوير ها إدخالها في العرش. وقيل: ذهاب صفوها، قاله الحسن وقتادة، وروي ذللك عن ابن عباس ومجاهد. وقال أبو عبيدة: كورت متل تكوير العمامة، تلف دهاب

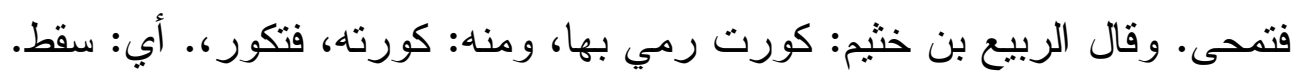

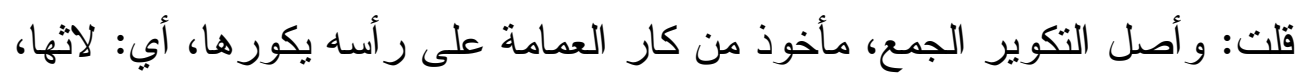
وجمعها، فهي تكور ، ثم يمحو ضو عها ثم يرمى بها، و الله أعلم. وقوله تعالى: (و إذا النجوم انكدرت) [التكوير: ب]، أي: انتشرت، قيل: تنتاثر

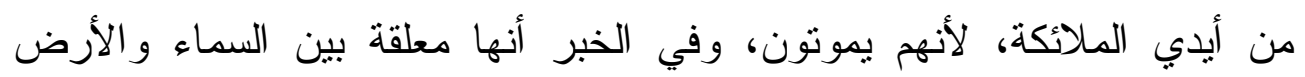


بسلاسل بأيدي الملائكة. وقال ابن عباس رضي اله عنه: انكدرت تغيرت، و أصل

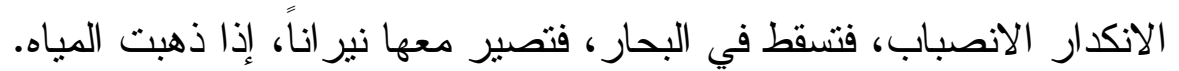
وقوله: (و إذا الجبال سيرت) [التكوير : r]، هو متل قوله: (ويوم نسير الجبال)

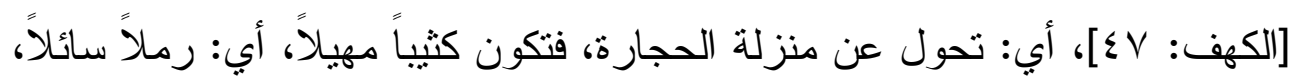

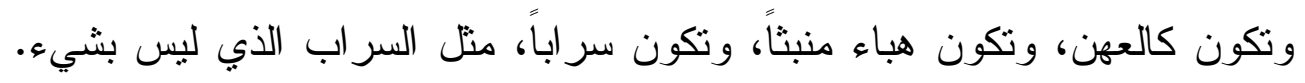

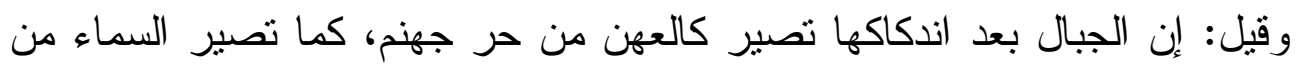
حر ها كالمهل.

قال الحليمي: وهذا و اله أعلم لأن مياه الأرض كانت حاجزة بين السماء

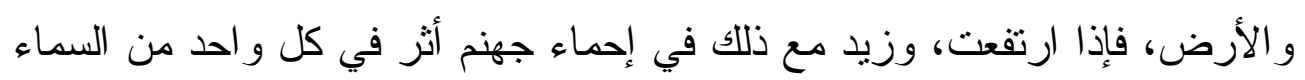
و الأرض ما ذكر .

وقوله: (و إذا العشار عطلت) [التكوير: ؟) أي: عطلها أهلها، فلم تحلب من

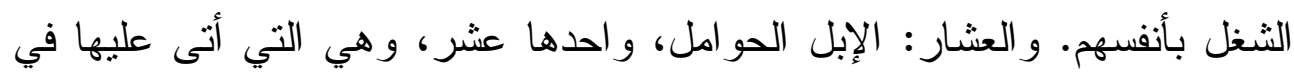

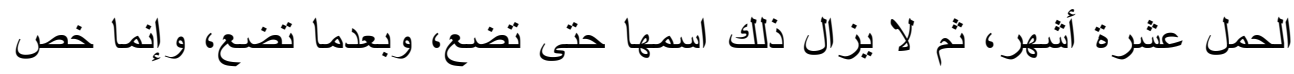

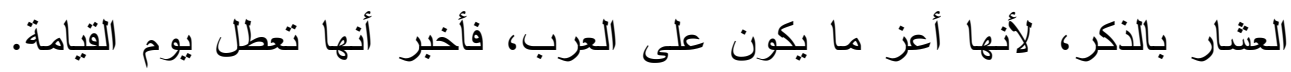

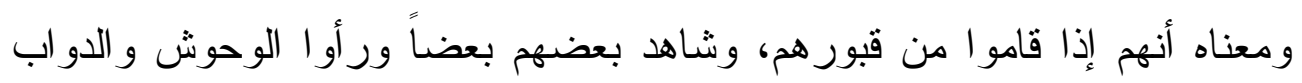

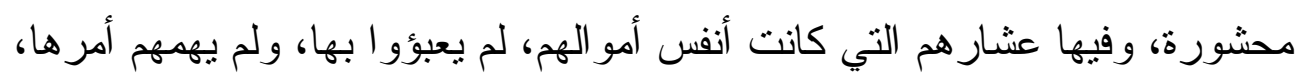

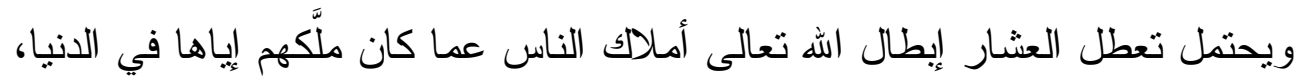

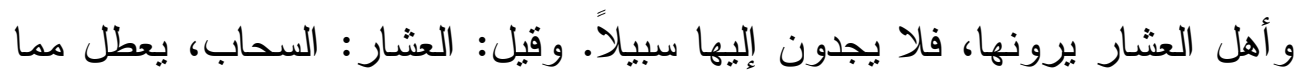

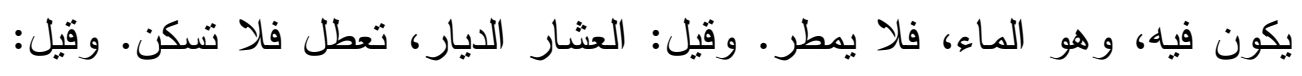

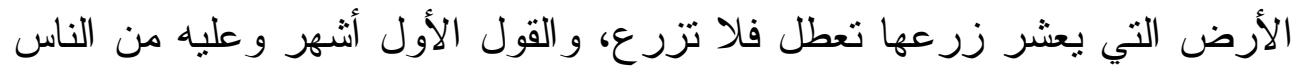


القيامة الكبرى (مشاهد ووقائع، دروس وعبر)

وقوله: (و إذا الوحوش حشرت) [التكوير : 0] أب: جمعت، و الحشر الجمع، وقد

وقوله (و إذا البحار سجرت) [التكوير: ج] أي: أوقدت، وصسارت ناراً. رو اه الضحالك عن ابن عباس رضي الله عنه. وقال قتادة: غار ماؤها، فذهب. وقال الحسن و الضحاك: فاضت. قال ابن أبي زمنين: سجرت حقيقته ملئت، فيفضي بعضها إلى بعض، فتصير شيئًا واحداً. وهو معنى قول الحسن. ويقال: إن الثمس وفئ: تلف، ثم ثلقى في البحار ، فمنها تحمى، وتتقلب نار اً. قال الحليمي: ويحتمل إن كان هذا هكذا أن البحار في قول من فسر التسجير بالامتلاء هو أن النار حينئذ تكون أكثرها، لأن الثمس أعظم من الأرض مرات كثيرة، فإذا كورت، و ألقيت في

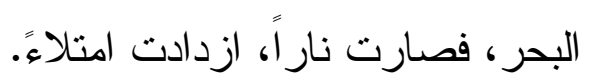

وقوله: (و إذا النفوس زوجت) [التكوير : V] تفسير الحسن أن تلحق كل شيعة شيعتها: اليهود باليهود، و النصارى بالنصارى، و المجوس بالمجوس، وكل من كان

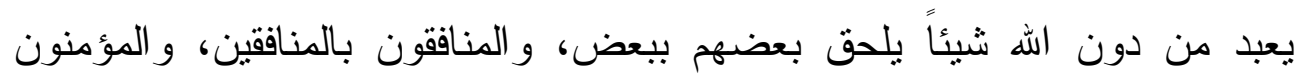
بالمؤمنين. وقال عكرمة: المعنى تقرن بأجسادها، أي: ترد إليها، وقيل: يقرن الغاوي بمن أغو اه من شيطان أو إنسان. يقرن المؤمنون بالحور العين، و الكافرون بالثياطين.

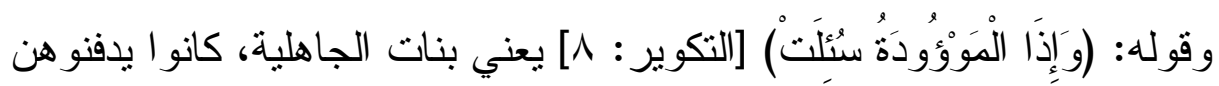
أحياء، لخصلتين: إحداهما: كانو ا يقولون: إن الملائكة بنات الله، فألحقو البنات به. الثانية: مخافة الحاجة و الإملاق، وسؤال الموعودة على وجه التوبيخ لقاتلها، كما يقال للطفل إذا ضرب: لم ضربت؟ وما ذنبك؟ وقال الحسن: أراد الله أن يوبخ قاتلها، لأنها قتلت بغير ذنب. وبعضهم يقر أ: و إذا الموعودة سألت، تعلق الجارية 
القيامة الكبرى (مشاهد ووقائع، دروس وعبر)

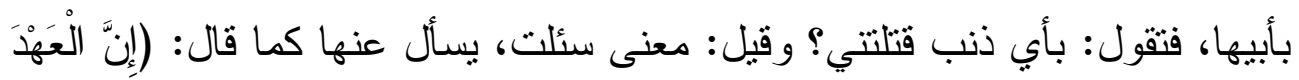

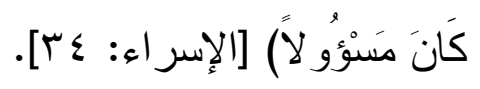

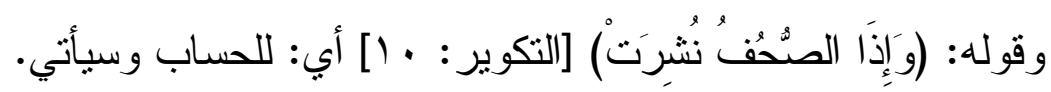

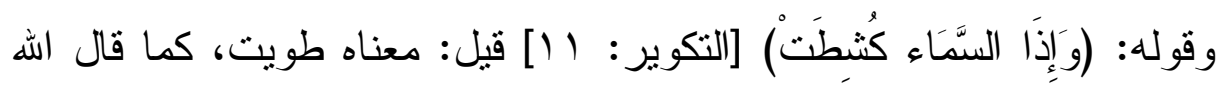

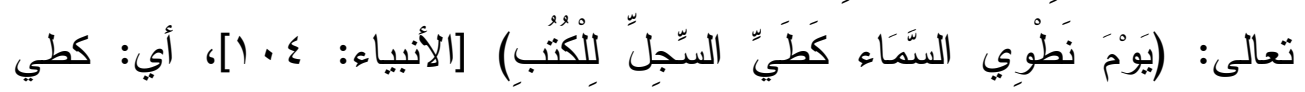

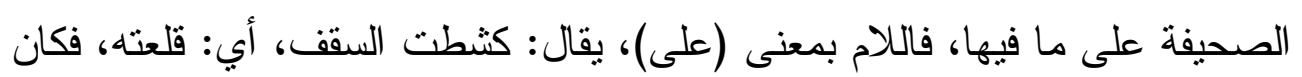

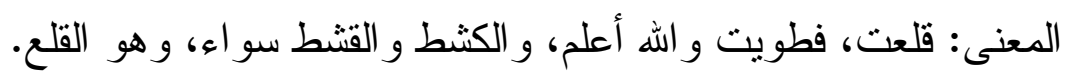
وقوله: (و إذا الجحيم سعرت) [التكوير : r 1]، أي: أوقدت. وقوله: (و إذا الجنة أزلفت) [التكوير : ب أ أي: قربت لأهلها، و أدنيت.

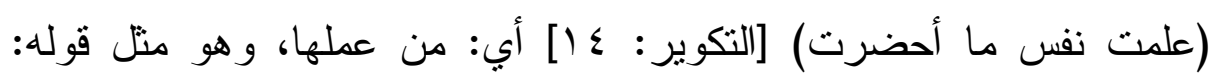

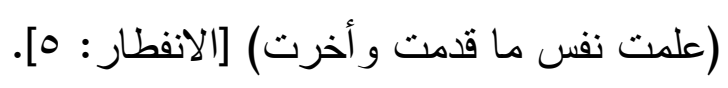

\section{النفخة الثانية - نفخة البعث \}ثم نفخ في أخرى فإذاهم قيام ينظرون\{:}

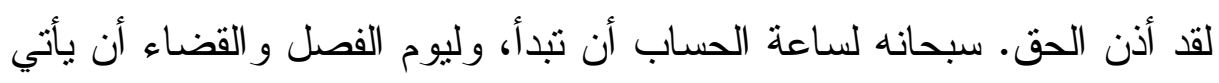
فحينئ يأمر الملك الموكل بالصور فينفخ فيه مرة أخرى وحينئذ تتابع المشاهد وتتو الى الأحداث و لا تتوقف حتى يستقر أهل الجنة في الجنة وأهل النار في النار. و على الرغم من أن هذه الأحداث وتلكم الأهو ال لما تقع بعد، فقد صورتها لنا آيات القرآن بصورة تشيب من هولها رؤوس الولدان كذللك تتاولت مو اقفها جميعاً بالثرح و التوضيح و البيان وذلك ليكون الناس جميعاً على بصيرة من أمر هم وبينة من شأنهم كلهم.

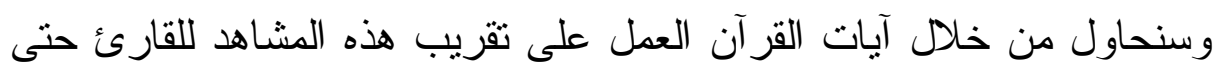

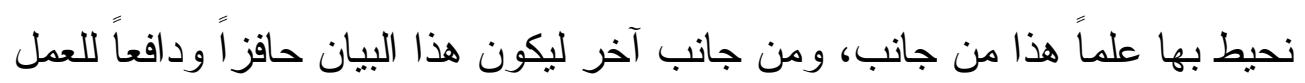


القيامة الكبرى (مشاهد ووقائع، دروس وعبر)

على الوقاية من عذاب الله في هذا اليوم وهي مواقف ومشاهد في يوم القيامة الأول منها تحت عنو ان:

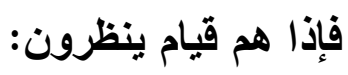

لقد تتاولت هذا الموقف الكثير من آيات القرآن وكل آية منها تتناول جانباً من الحدث وتعبر عن وضع وعن حالة من شدة الكرب في هذا اليوم، وتصف حالة الخزي و الذل و الهوان التي يحشر عليها الكفار و المجرمون في يوم القيامة: -

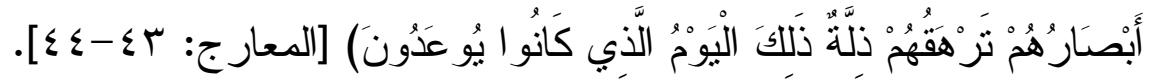
و الأجداث هي القبور، و النص يصور سرعة خروجهم من القبور في ذلك اليوم منطلقين إلى مصدر الصوت كأنهم يسرعون إلى الأنصاب التي كانو ا يعبدونها في الدنيا، ولكنهم اليوم لا ينطلقون فرحين أثرين بطرين كما كان حالهم عندما كانوا يقصدون الأنصاب، بل هم أذلاء، أبصار هم خاثعة، و الصغار يعلو هم، على النعت الذي كان يعدهم الله به في اليوم.

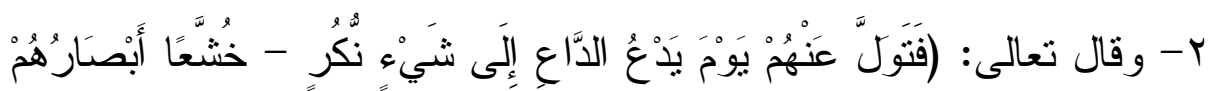

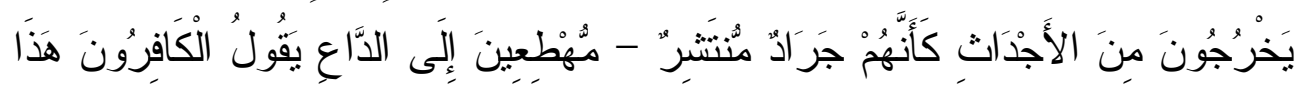

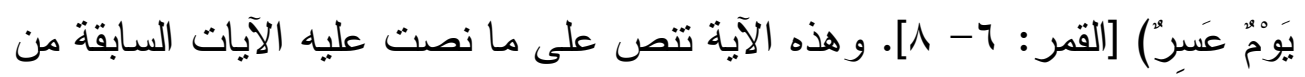
خروجهم خاشعي الأبصار أذلاء، مسرعين إلى مصدر الصوت الذي يناديهم ويدعوهم، وتزيدنا بياناً بإعطائنا صورة حية لمشهد البعث و النشور، فحالهم في ذلك اليوم في حركتهم و انطلاقتهم وهم يخرجون مسرعين كحال الجر اد المنتشر، ويفيدنا

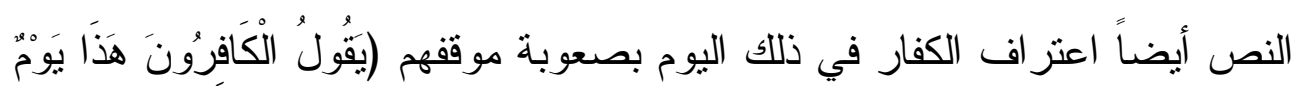

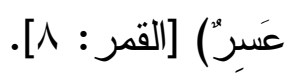


القيامة الكبرى (مشاهد ووقائع، دروس وعبر)

r- ويفيدنا نص ثالث أن الكفار ينادون بالويل و الثبور عندما ينفخ في الصور

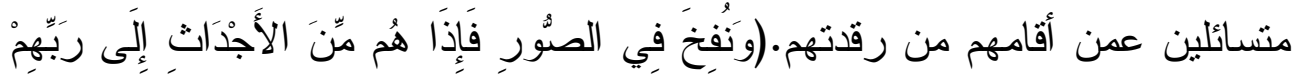

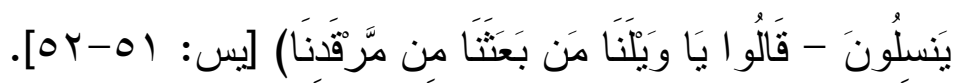

\section{أول من تنثق عنه الأرض يوم القيامة}

لقد بينا في الفقرات السابقة ما يحدث بين النفختين ففي صحيح مسلم عن عبد

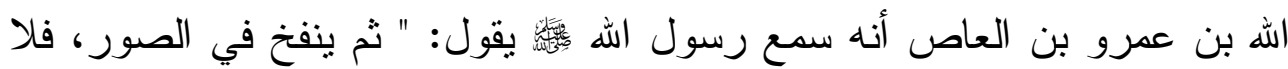

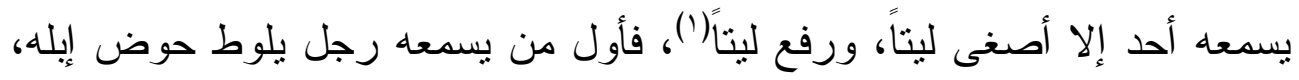

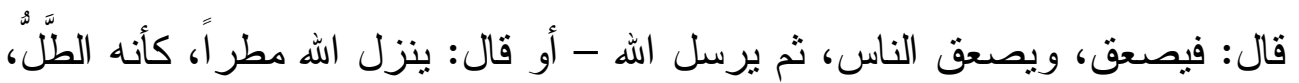
أو الظِّل، (نعمان (־الثاك) فنتبت منه أجساد الناس، ثم ينفخ فيه أخرى فإذا هم قيام

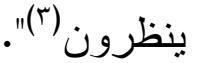

لقد انتفض الخلق من رقدتهم وإن الدق لقادر على أن يعيد خلقهم مرة أخرى

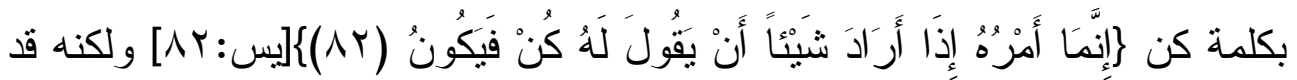

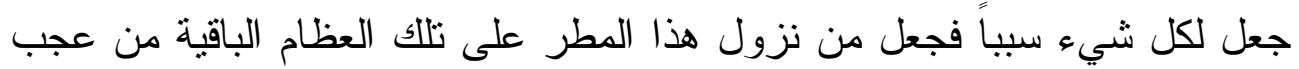

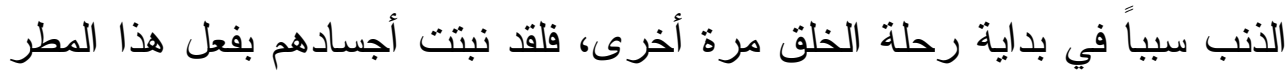

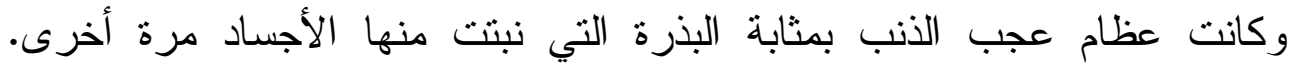

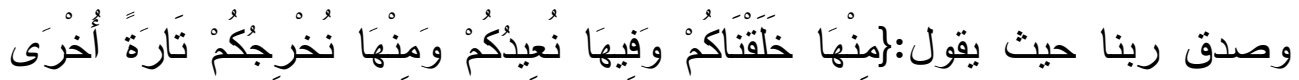
$[00: b]\{(00)$

لقد ربت الأرض و انتفخت كالمرأة الحامل بالجنين في أحشائها فهي تستعد

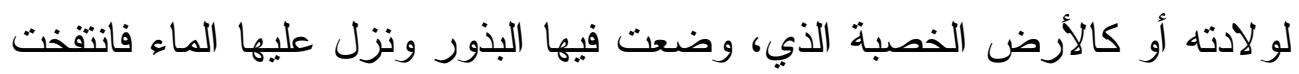


القيامة الكبرى (مشاهد ووقائع، دروس وعبر)

البذور في بطنها وتكاد أن تخرج منها فهي كذلك يوم القبامة تتهيأ الأجساد وتستعد للخروج ومتى تتنظر إنها تتنظر هذه الصيحة: \}ثم نفخ في أخرى فإذاهم قيام ينظرون\{

بمجرد سماع الخلق لهذه الصيحة إذا هم قيام ينظرون تتشقق عنهم الأرض

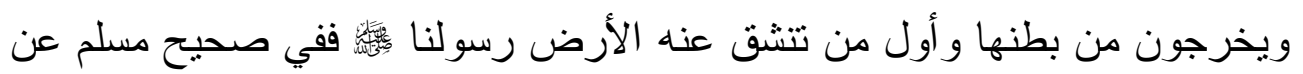

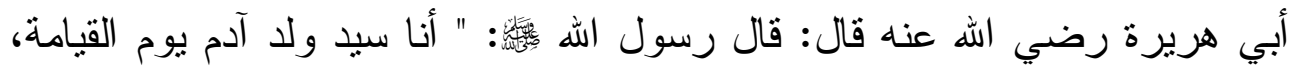

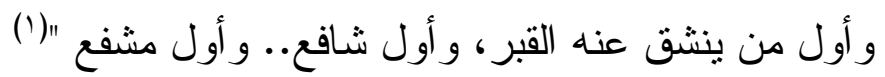

إنه رسول اله

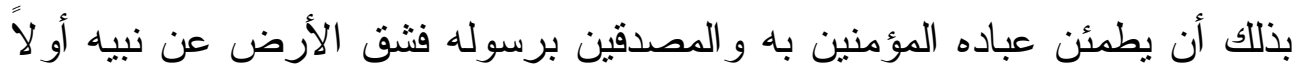

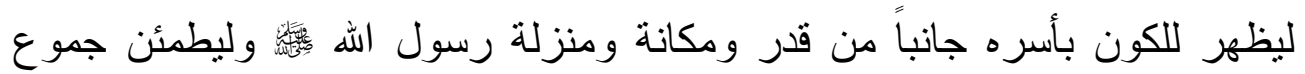
المؤمنين بعد ذلك حينما تتنق عنهم قبورهم يستبشرون ويطمئنون فهذا إمامهم ورسولهم ونبيهم قد سبقهم إلى ساحات العرض و الحساب وصدق ربنا حيث يقول:

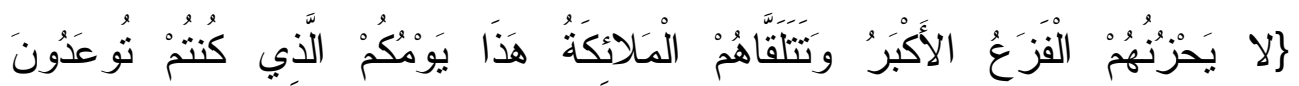
[الأنبياء. (1)

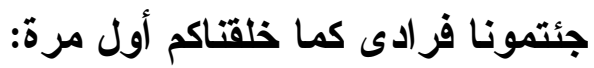

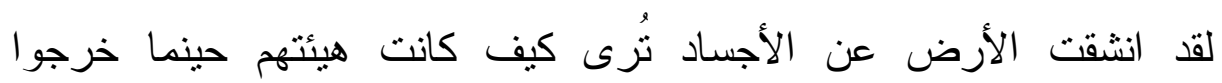

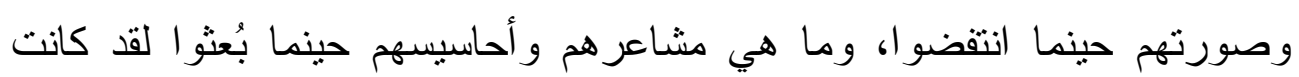
على النحو التالي:

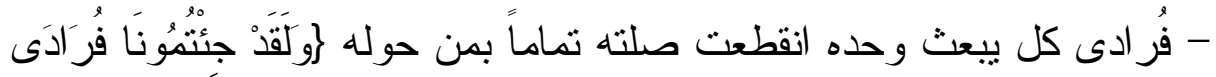




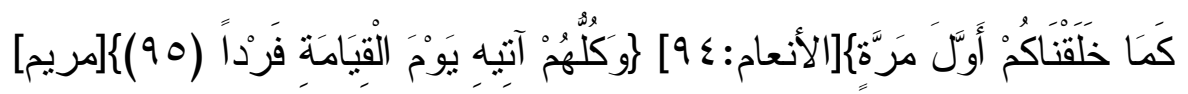

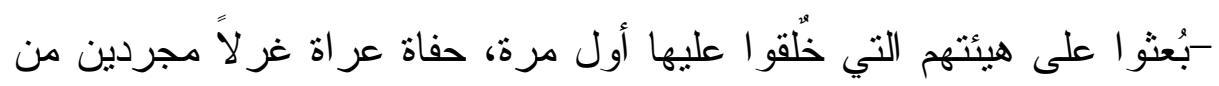

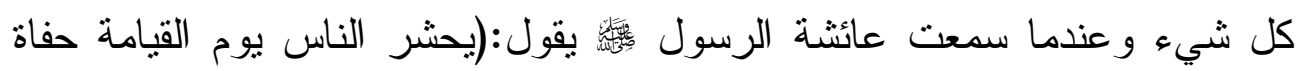

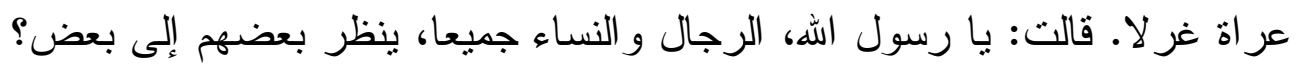
قال: يا عائثة الأمر أثند من أن ينظر بعضهم إلى بعض) متفق عليه (1).

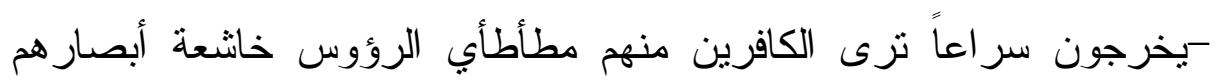

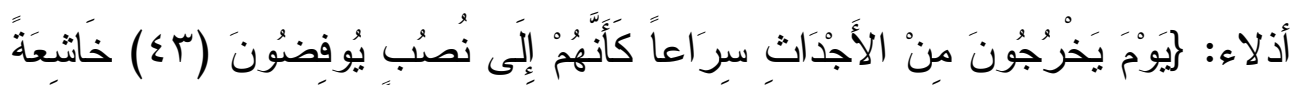

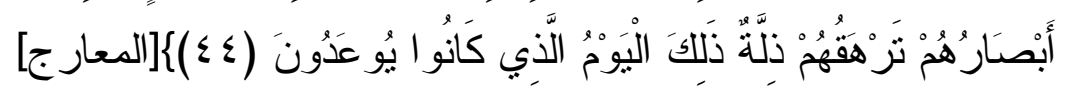

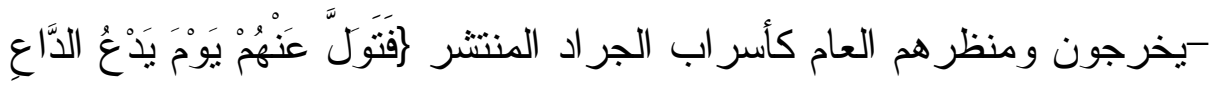

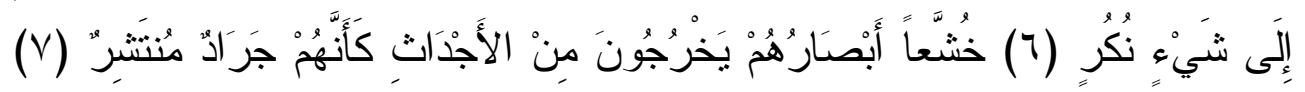

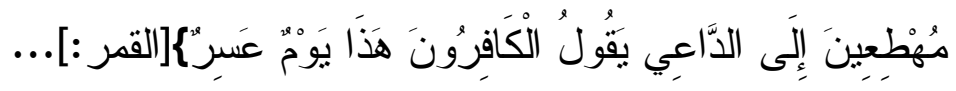

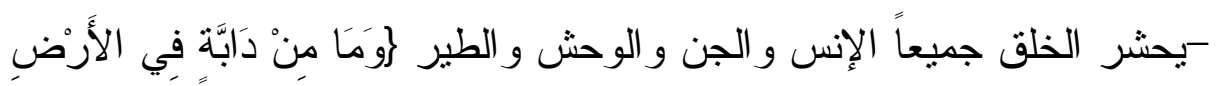

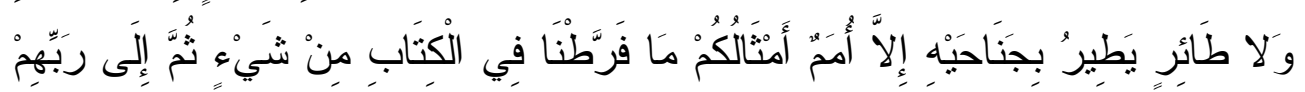

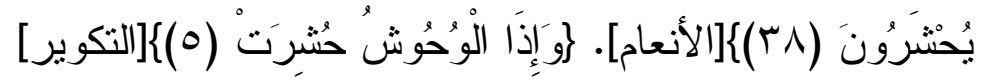

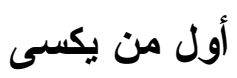
إذا كان الحق سبحانه قد أكرم نبيه محمداً أبس أنه أول من تتثق عنه الأرض،

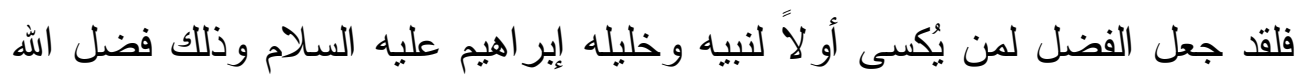

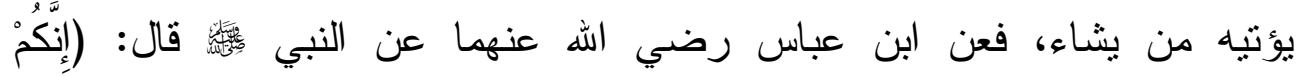

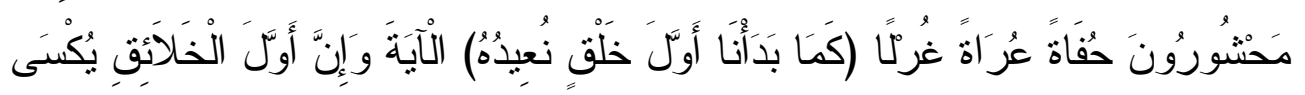

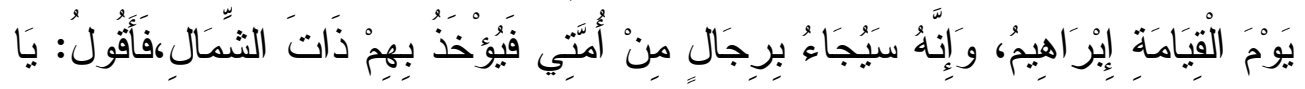




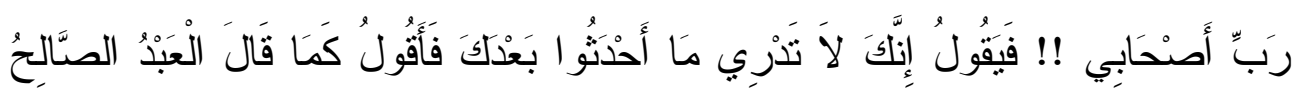

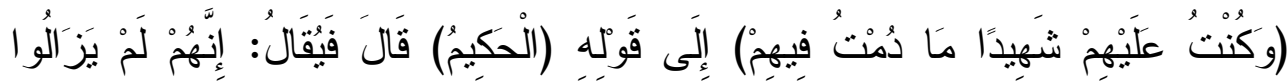

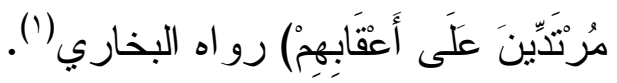

قال ابن حجر : وأخرج البيهقي من طريق ابن عباس نحو حديث الباب وز اد

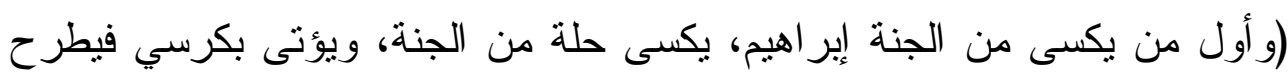

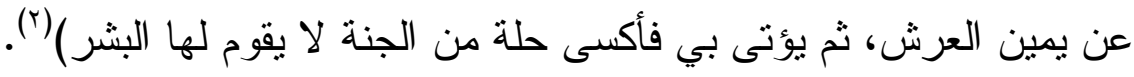
وذكر العلماء أن تقديم إير اهيم على غيره بالكسوة في يوم القيامة، لأنه لم يكن

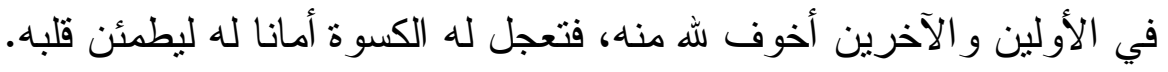
ويحتمل لأنه - كما جاء في الحديث - أول من لبس السر اويل إذا صلى مبالغة

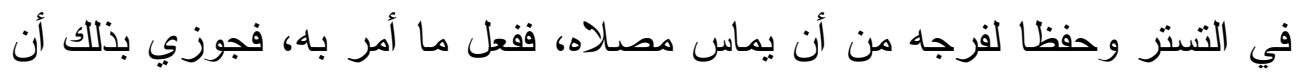

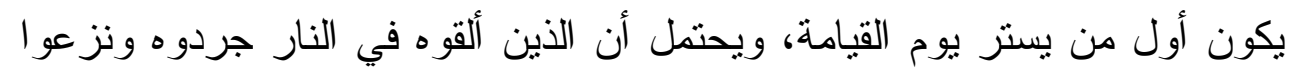
ثيابه على أعين الناس، كمن ير اد قتله، فجوزي بكسوته في يوم القيامة أول الناس

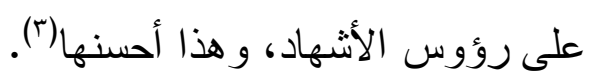
و عندما سمعت عائشة الرسول غر لا. قالت: با رسول اله، الرجال و النساء جميعا، بنظر بعضهم إلى بعض؟ قال: يا عائثة الأمر أثند من أن ينظر بعضهم إلى بعض) متفق عليه(أ). وقد جاء في بعض النصوص أن كل إنسان يبعث في ثيابه الني مات فيها، فقد

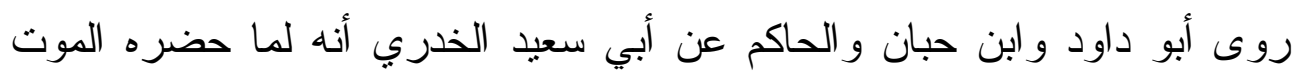

$$
\begin{aligned}
& \text { (1) البخاري. كتاب أحاديث الأنبياء. حديث رقم ...1 (1) }
\end{aligned}
$$

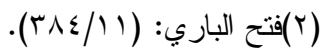

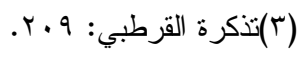

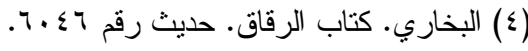


القيامة الكبرى (مشاهد ووقائع، دروس وعبر)

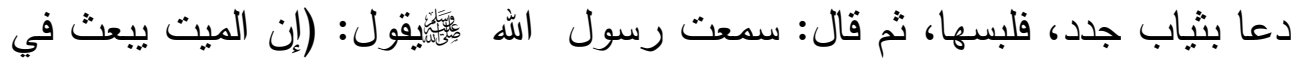
ثيابه التي يموت فيها) وقال الحاكم صحيح على شرط الثيخين وو افقه الذهبي ('). وقد وفق البيهقي بين الحديثين السابقين بثلاثة أوجه:

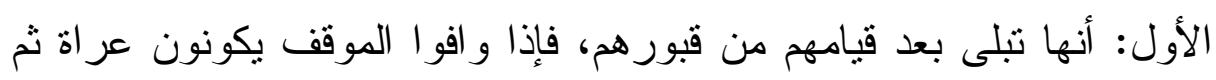
يلبسون من ثياب الجنة. الثاني: أنه إذا كسي الأنبياء ثم الصديقون، ثم من بعدهم على مر اتبهم، فنكون كسوة كل إنسان من جنس ما يموت فيه، ثم إذا دخلو الجنة لبسو ا من ثياب الجنة.

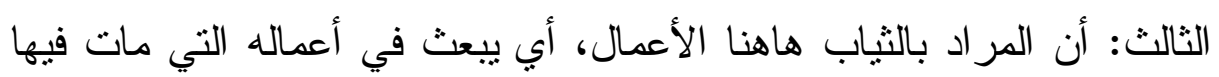

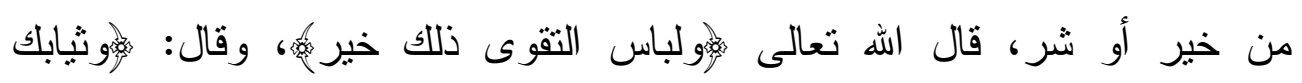
فطهر من خير.

و استتهد البيهقي على هذا الجواب الأخير بحديث الأعمش عن أبي سفيان عن

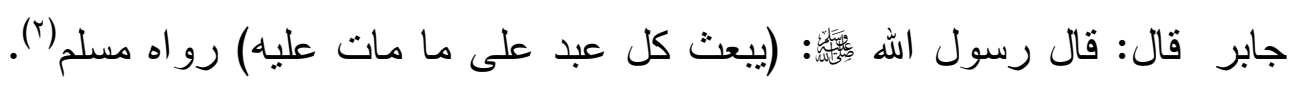

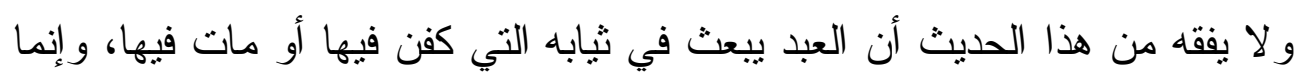

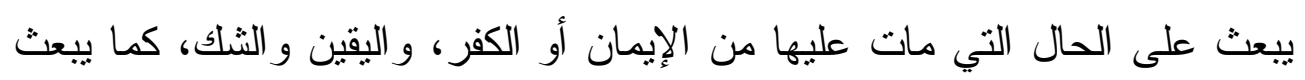
على العمل الذي كان يعمله عند موته يدل على هذا ما رواه عبد الله بن عمر قال:

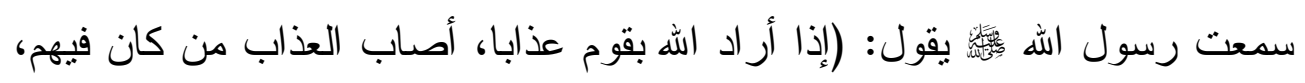
ثم بعثو ا على أعمالهم) رو اه مسلم (r). وجاء أن الذب يموت وهو محرم يبعث يوم القيامة ملبيا، فعن عبد الله بن

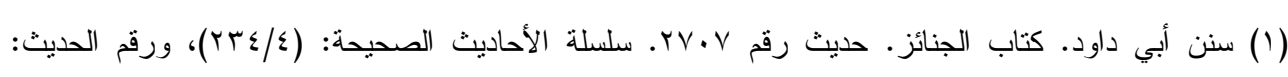


القيامة الكبرى (مشاهد ووقائع، دروس وعبر)

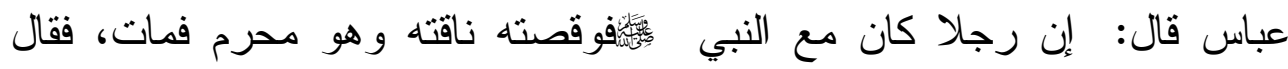

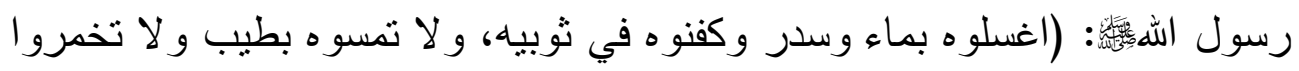

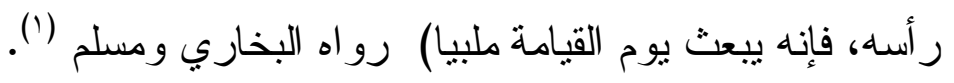

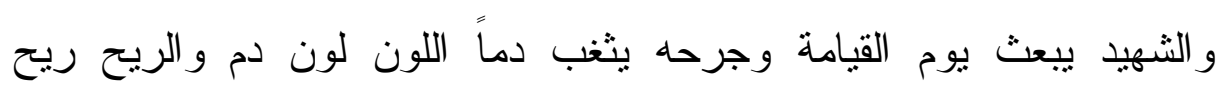

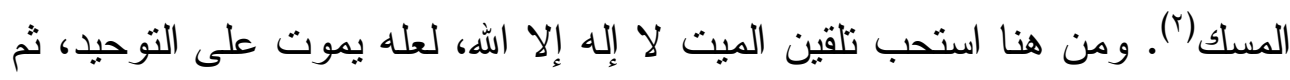

يبعث يوم القيامة ناطقا بهذه الكلمة الطيبة.

\section{الأرض التي يحشر إليها الخلق يوم القيامة}

مما لا شك فيه أن الخلق سيحشرون إلى أرض أخرى غير الأرض التي كانو التها

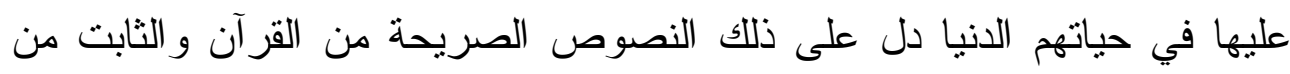
حديث رسول الله

- يقول الحق سبحانه:هوبوم تبدل الأرض غير الأرض و السماوات وبرزوا لله

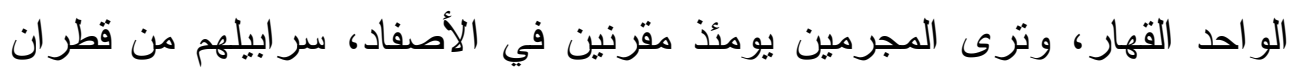

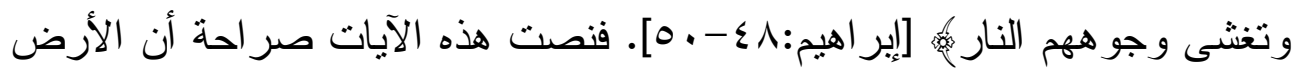
تبدل غير الأرض وكذللك السماوات.

- وبينت الأحاديث الصحيحة أن الخلق يحشرون إلى أرض جرداء بيضاء عفر اء ملساء كقرص النقي ففي صحيحي البخاري ومسلم عن سهل بن سعد قال: سمعت رسول الله

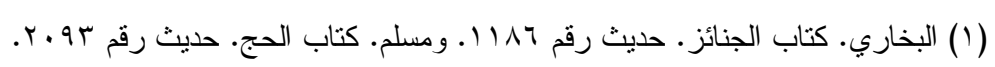

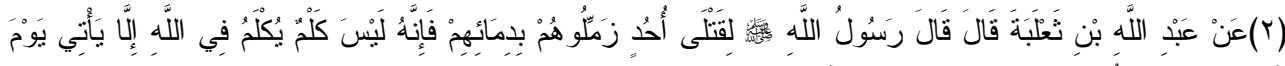

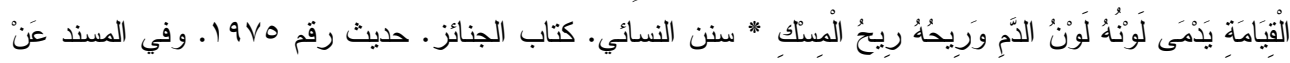

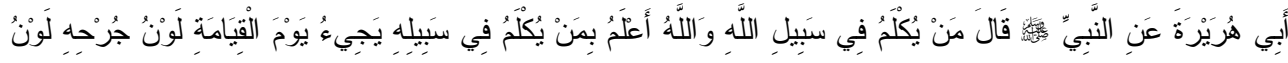

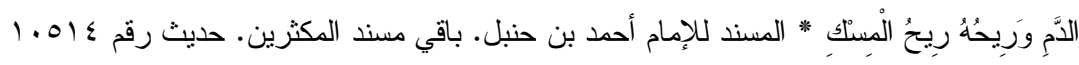


القيامة الكبرى (مشاهد ووقائع، دروس وعبر)

كقرصة النقي " فال سهل أو غيره: " لبس فيها معلم لأحد "(().

قال الخطابي: العفر: بياض ليس بناصع. وقال عباض: العفر بياض يضرب

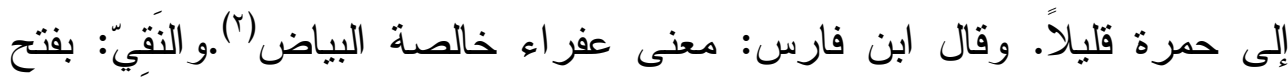

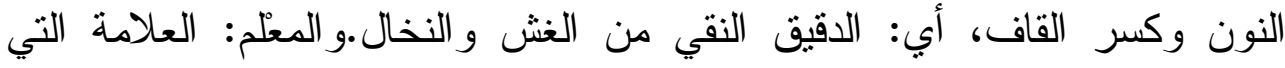
يُهندى بها إلى الطريق، كالجبل و الصخرة، أو ما يضعه الناس دالاً على الطرقات،

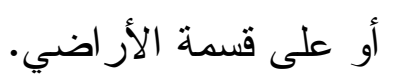

ولقد جاءت نصوص كثثرة عن عدد من الصحابة تقيد معنى الحديث الذي

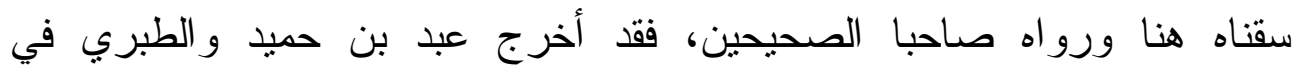
تفاسيرهم و البيهقي في شعب الإيمان من طريق عمرو بن ميمون عن عبد اله ابن

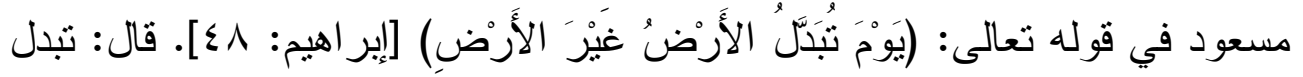

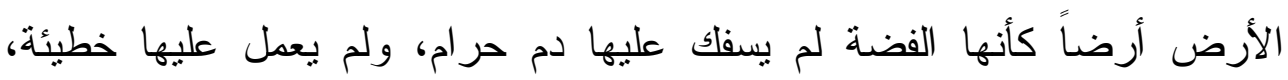
ورجاله رجال الصحيح، وهو موقوف، وأخرجه البيهقي من وجه آخر مرفوع.

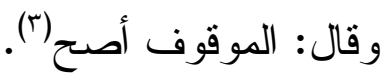
و أخرجه الطبري و الحاكم من طريق عاصم عن زر بن حبيش عن ابن مسعود بلفظ: " أرض بيضاء كأنها سبيكة فضة " ورجاله موثقون أيضاً (؛). وعند عبد بن حميد من طريق الحكم بن أبان عن عكرمة قال: بلغنا أن هذه

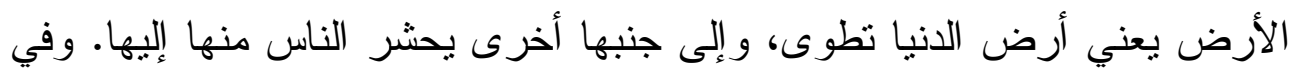


القيامة الكبرى (مشاهد ووقائع، دروس وعبر)

حديث الصور الطويل: " تبدَّل الأرض غير الأرض و السماوات، فيبسطها

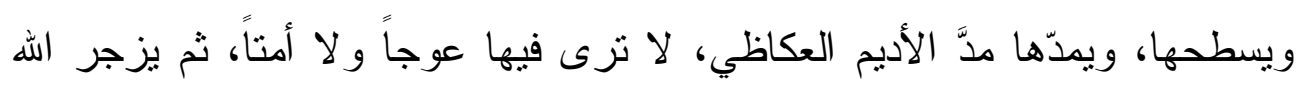

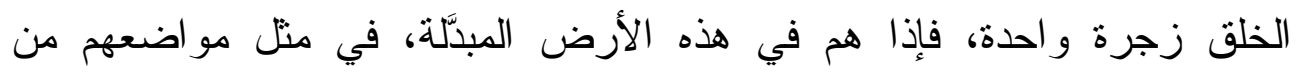

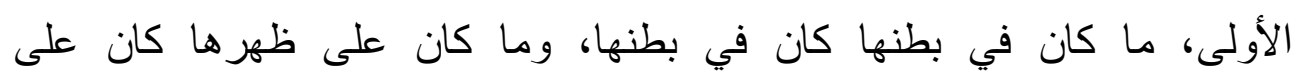

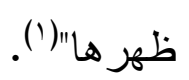

- يقول سبحانه إِيوم نطوي السماء كطي السجل للكتب كما بدأنا أول خلق

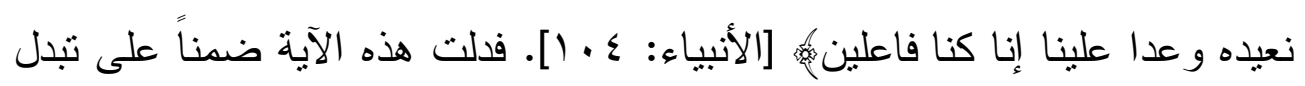
السماء وقد طوى اله السماو ات و الأرض بيمينه و أكد على المعنى حديث رسول الله

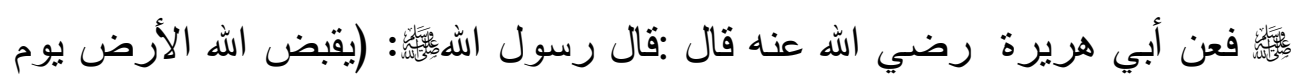

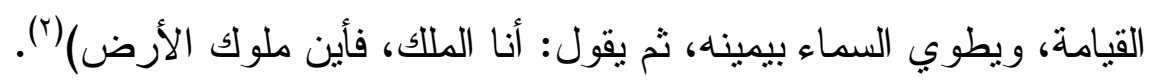

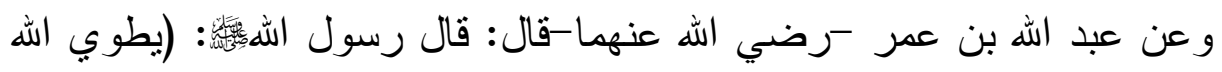
السماو ات يوم القيامة، ثم يأخذهن بيده اليمنى، ثم يقول: أنا الملك، أين الجبارون؟

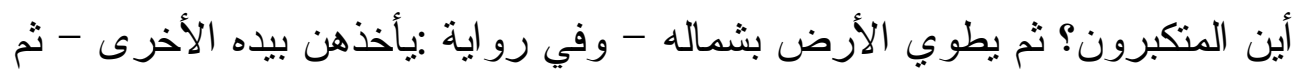

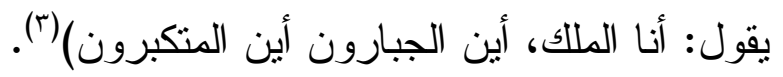
ومما لا شك فيه أن الأرض التي نحيا عليها ستكون يوم القيامة أحد شهود

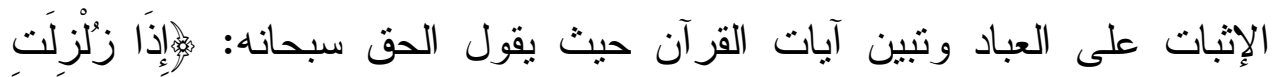

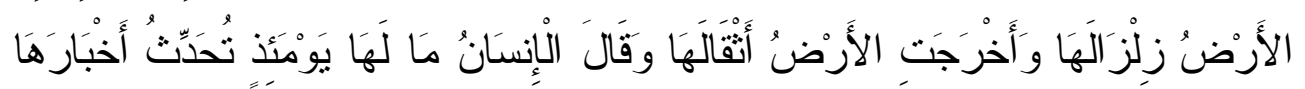

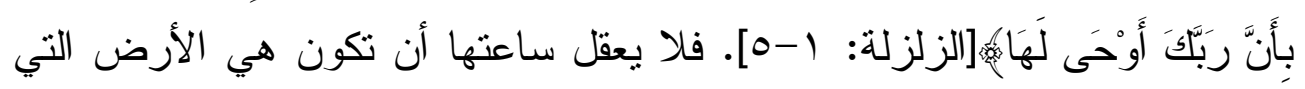
يحشرون ويققون عليها وقد ازدحت بهم فليس فيها موطئ لقدم وتكون شاهد إثبات

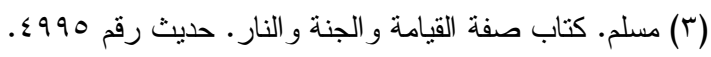




$$
\text { عليهم في ذات الوقت. }
$$

وقد ذهب بعض أهل العلم إلى أن الذي يبدل من الأرض إنما هو صفاتها

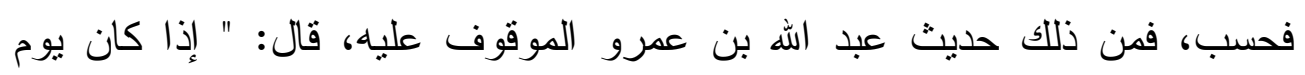

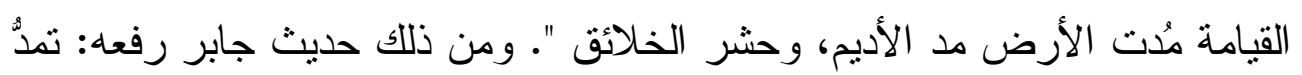

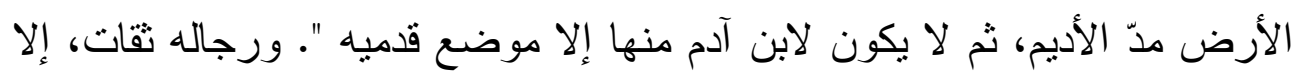
أنه اختلف على الزهري في صحابيه(').

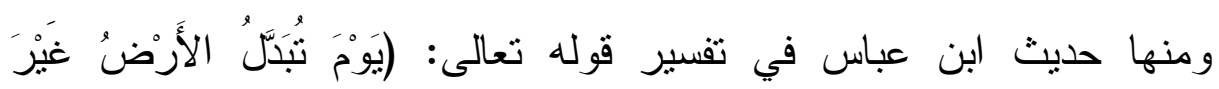

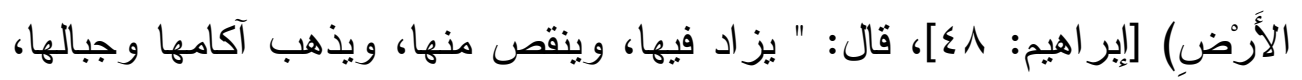

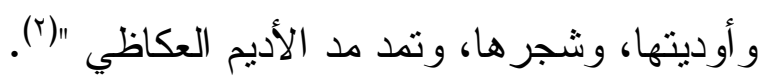

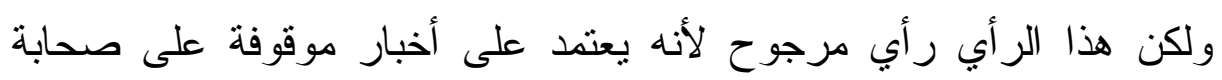
رسول الله حديث رسول اله

\section{نظرة على حال العباد فوق أرض المحشر:}

لقد بُعث الخلق من رقدتهم وانتفضوا من قبورهم وحشر الإنس والجن

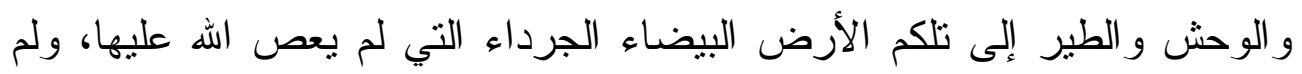

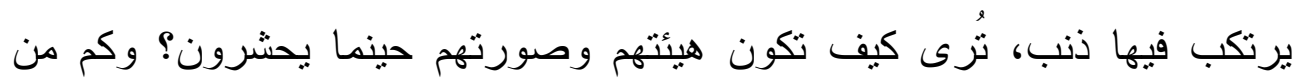
الوقت ينتظرون حتى يتم الفصل و القضاء بين الخلائق؟ لقد رسمت آيات القرآن آن

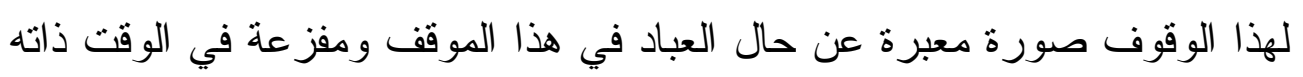
ومن خلال النقاط التالية سنحاول بيان ذلك:

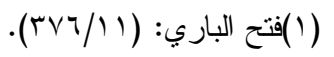

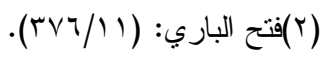




\section{كرب لا يُحتمل وهم وغم لا يُطاق}

لقد وصل الكرب و الغم من الناس مبلغه، حتى تركهم في حالة من الذهول

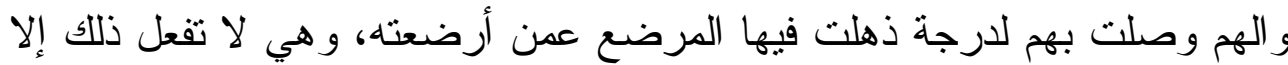
لأمر عصيب، وحتى بدت صورة الناس كصورة السكارى و المخمورين لا يفيقون و لا بدركون، ولكنهم ليسو اسكارى من شر اب يتعاطونه أو مخدر قد تتاولوه، و إنما

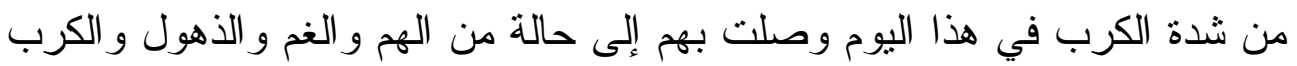

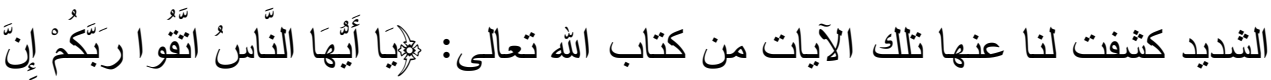

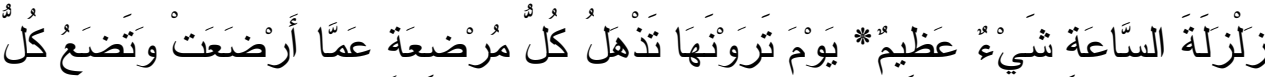

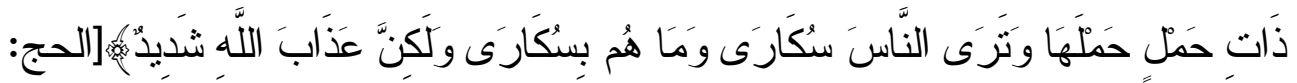
$\cdot[r-1$

أمام الكثير من النكبات نرى النَّاس يصابون بالهذيان، ويكلِّون أنفسهر من

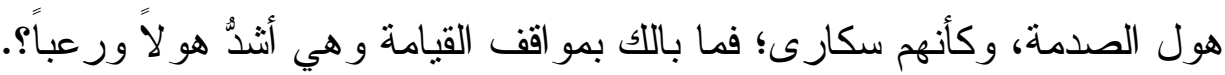

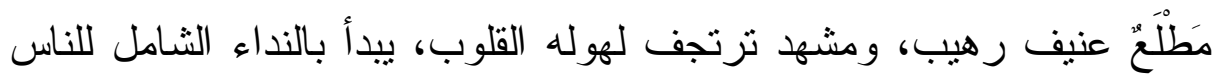

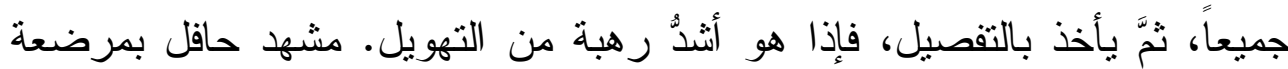

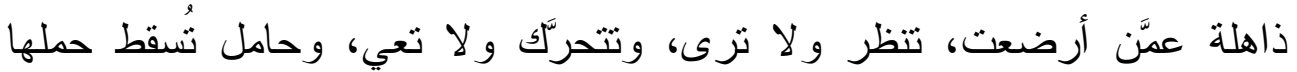
للرعب الَّني ينتابها، فأي موقف هذا الذَّي يسلب الأم عاطفتها نحو رضيعها فتذهل عنه، و أي خوف هذا الَّني يجعل الحامل تسقط حملها؟؟. إنها صورة منتقاة بدقَّة، تنتّل العطف و الحنان وهو يذوب ويتلاشى أمام هول يوم القيامة، حيث تتهار أقس لتس

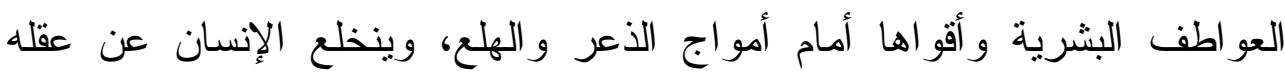
و تتفكيره مذهو لاً مخبو لاً.

إنه حساب اله قد حانت ساعته، فالنَّاس سكارى وما هم بسكارى، يتبدَّى السُّكُ لهر 
القيامة الكبرى (مشاهد ووقائع، دروس وعبر)

في نظر اتهم الذاهلة، وفي خطواتهم المترنِّة، دون أن يشربوا الخمر • إنه مشهد مزدحم بذالك الحشد المنماوج، تكاد العين تبصره لحظة التلاوة، بينما الخيال يتملاًّ،

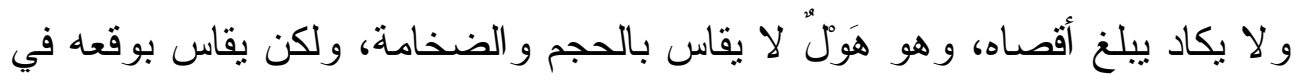

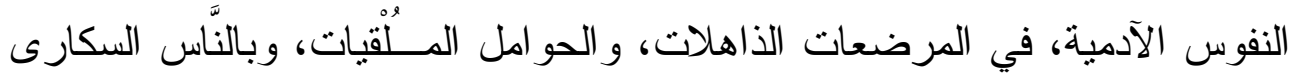
لأن عذاب اله شديد.

فأين يكمن الرعب؟ هل هو في اثنتعال البحار ، أم في زوال الجبال، أم في هاب

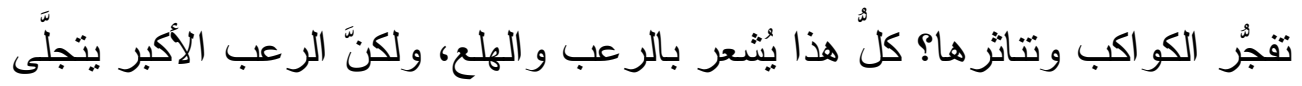

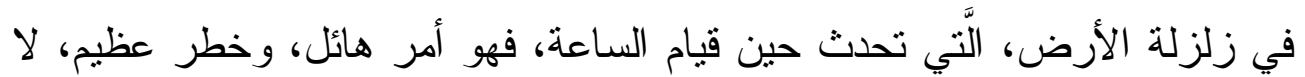

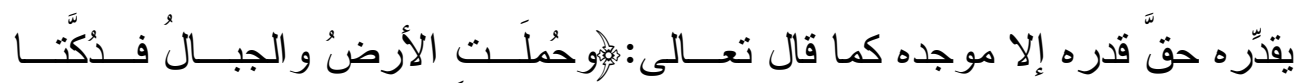

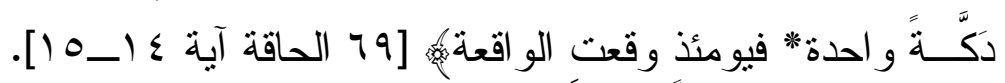

فإذا كانت الزلزلة وحدها لا تُحتمل، فما باللك بما يحدث في ذلك اليوم، من

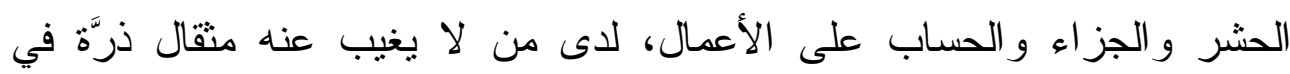

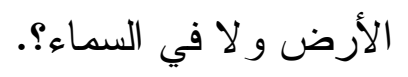

\section{أحمال وأثقال تنوء بحملها الجبال الراسيات}

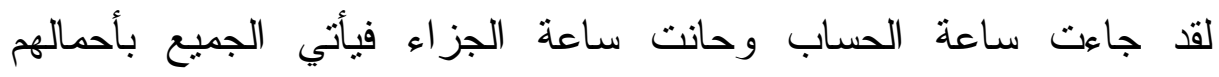
وليتقدموا إلى العرض بأثقالهم و أوزارهم التي اقترفوها و آثامهم التي ارتكبو ها يقول

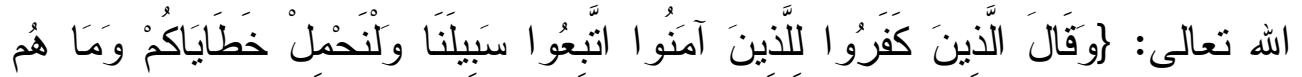

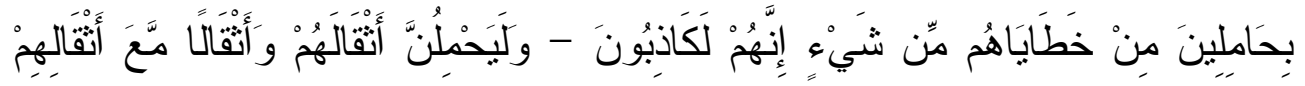

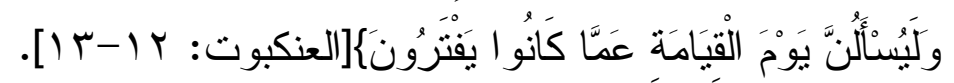

إنها الخطايا التي ارتكبوها و الآثام التي اقترفوها يأنون بها حاملين لها على

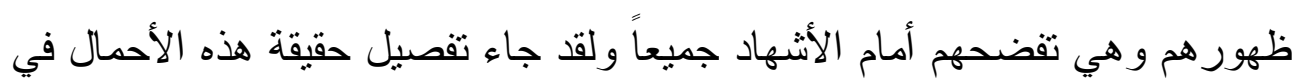


القيامة الكبرى (مشاهد ووقائع، دروس وعبر)

بيان رسول الله

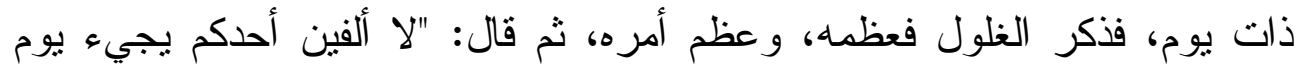

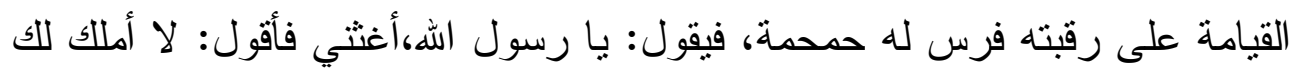

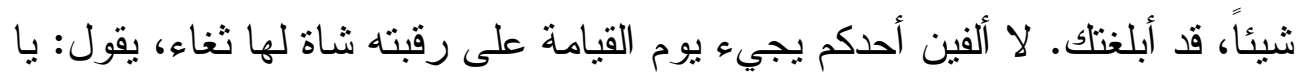

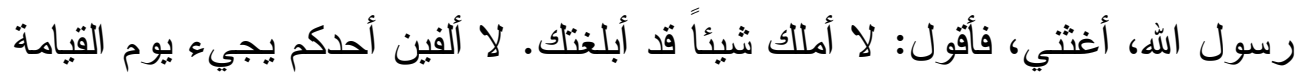

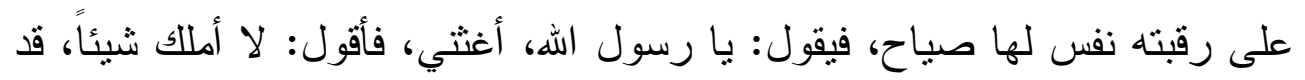

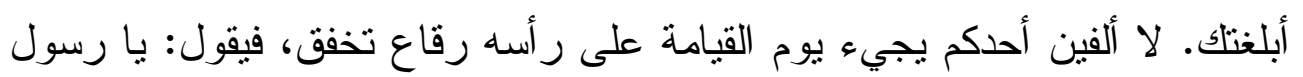

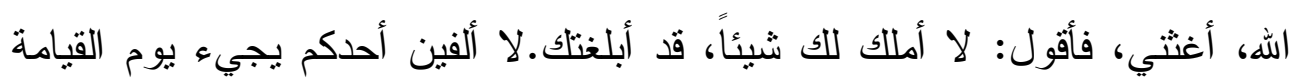

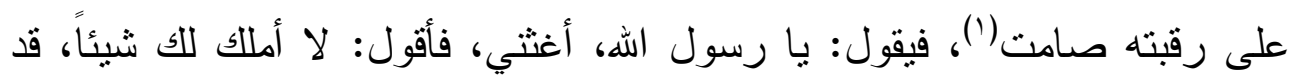
أبلغتلك " متفق عليه، وهذا لفظ مسلم، وهو أتم (r). وأخرج الطبراني في ((معجمه الكبير))، و البيهقي في ((السنن)) و الحميدي في

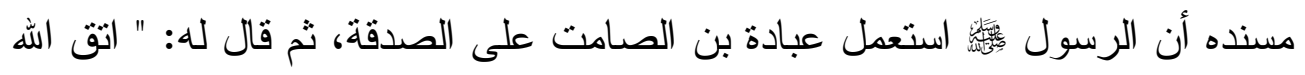

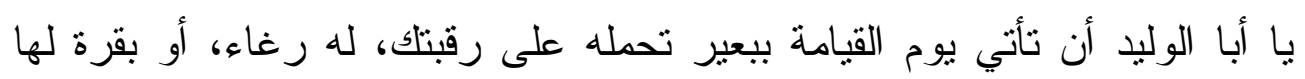

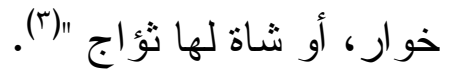
وقد ساق ابن كثير في تفسيره الأحاديث المرهبة من الغلول، ومنها أحاديث غلول العمال من الصدقات، وساق حديث أبي حميد الساعدي قال: " استعمل رسول

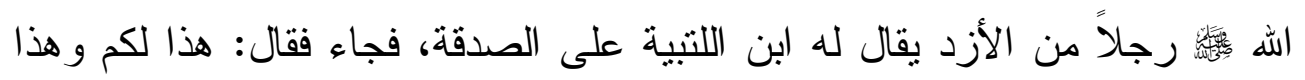

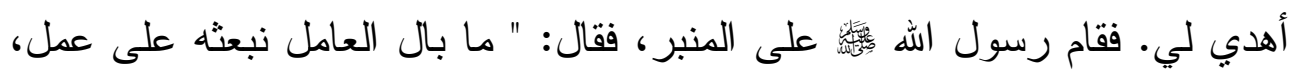

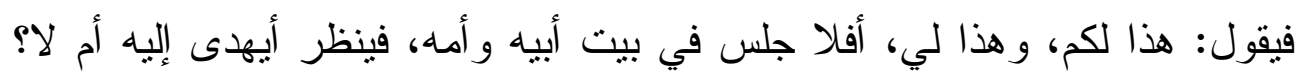

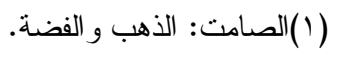

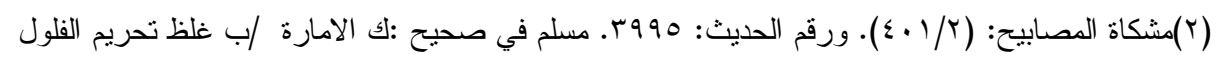

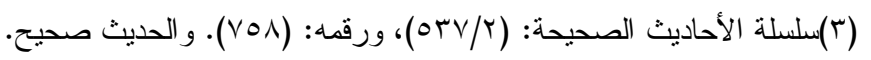


و الذي نفس محمد بيده لا يأني أحدكم منها بشيء إلا جاء به يوم القيامة على رقبته.

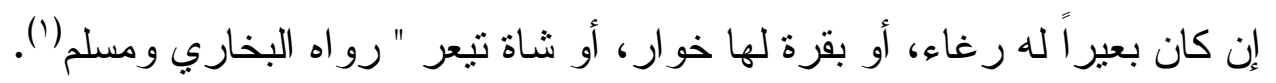

شمس حارقة وعرق يغرق الأقوام

ما اقتصرت أهو ال يوم القيامة على ذلك بل تدنو الثمس من رؤوس العباد في ذلك اليوم حتى لا يكون بينها وبينهم إلا مقدار ميل واحد، ولو لا أنهم مخلوقون خلقاً

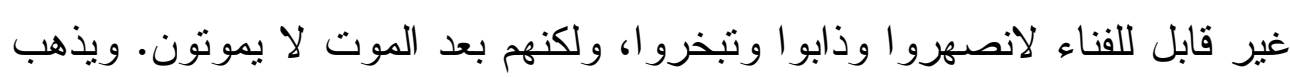

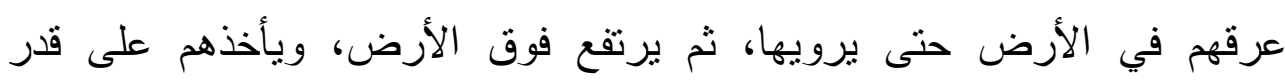

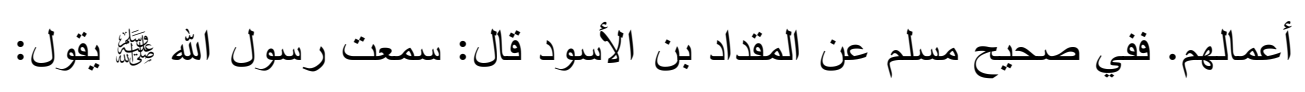
" تدنى الثمس يوم القيامة من الخلق، حتى تكون منهم كمقدار ميل ".

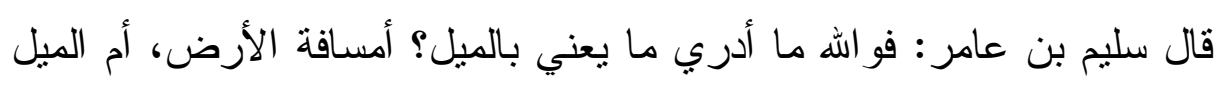

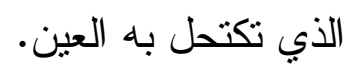

قال: " فيكون الناس على قدر أعمالهم في العرق، فمنهم من يكون إلى كعبيه.

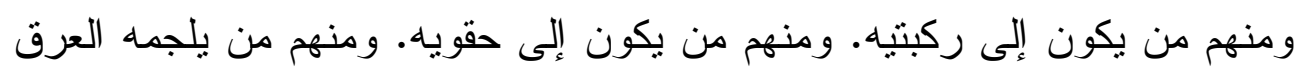
إلجاماً" قال: و أثنار رسول اله بيده إلى فيه(؟).

وفي صحيحي البخاري ومسلم عن ابن عمر رضي الله عنهما عن النبي

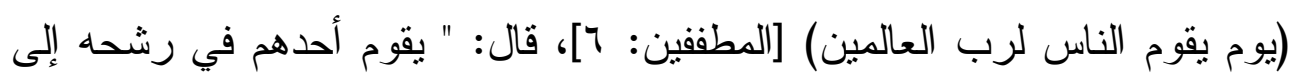
أنصاف أذنيه "( (").

(1) (1) (1) البحيح

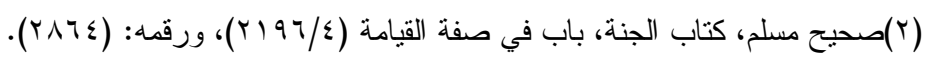

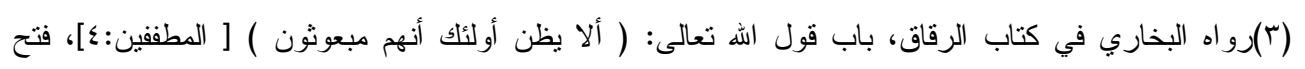

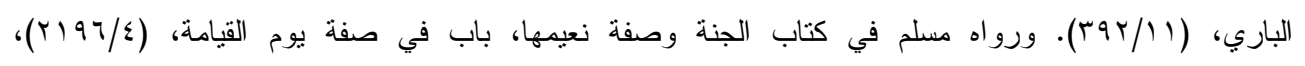

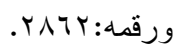


وفي صحيحي البخاري ومسلم عن أبي هريرة رضي اله عنه أن رسول الله

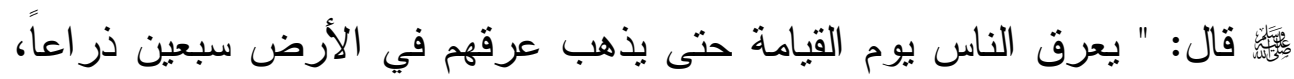

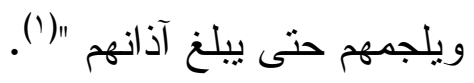

إنها آثار الخطايا والذنوب ظهرت على أجسادهم على صورة عرق يتصبب

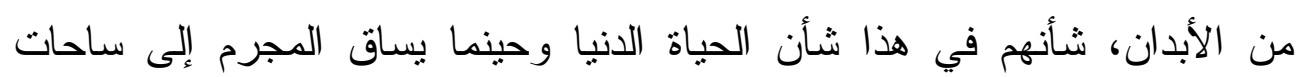
القضاء تجده في حالة من الذل و المهانة و الخزي فكذللك حال العباد في هذان الئهان اليوم يتصبب العرق من أبدانهم على قدر خطاياهم وذنوبهم فيغرقهم من تحت أقدامهم حتى يصل في الأرض سبعين ذر اعاً ويرتفع فوق أجسادهم فمنهم يصل إلى ركبنيه أو إلى وسطه أو إلى صدره أو يلجمه العرق. نسائم الرحمات

إذا كان الهول شديداً يوم القيامة و الخطب جسيماً فالشمس حارقة و العرق تغرق

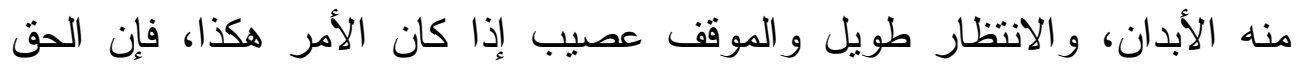
سبحانه برحم من عباده الرحماء، فيتغد عباده المؤمنين بفضائل عظيمة في مثل لهول هذا الموقف وتهب عليهم نسائم الرحمات فمنها: - لا يحزنهم الفزع الأكبر

يفزع الناس يوم القيامة و لا يفزعون إنهم صنف من عباد اله لا يفزعون عندما

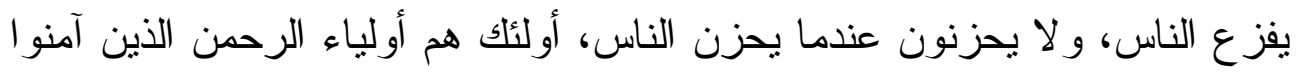

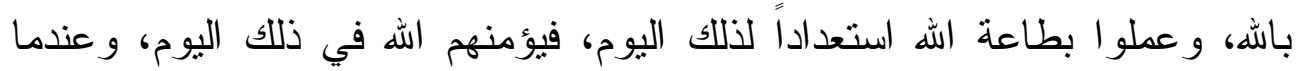

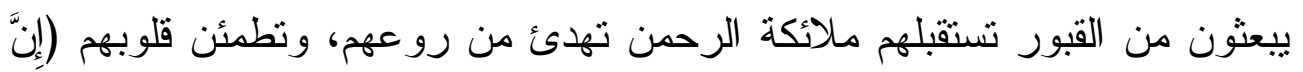

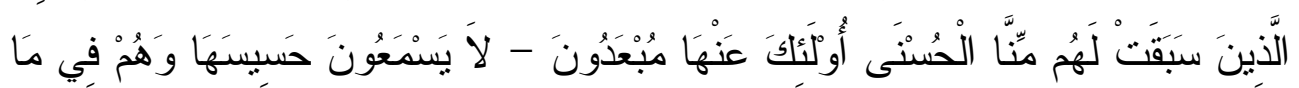
( (1)المصادر السابقة، و السياق للبخاري. 


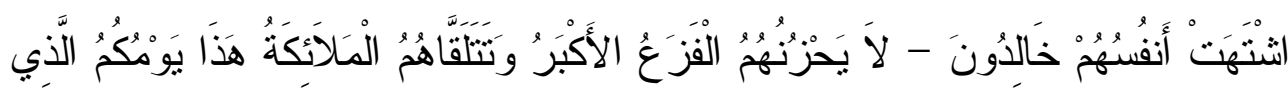

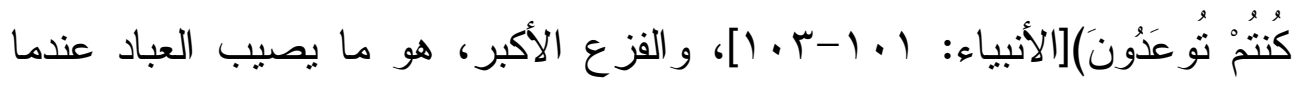

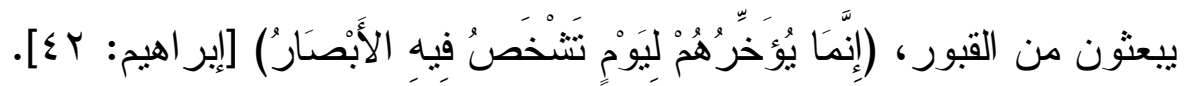

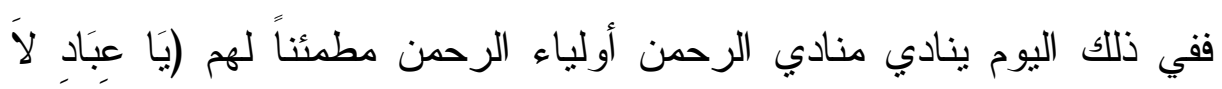

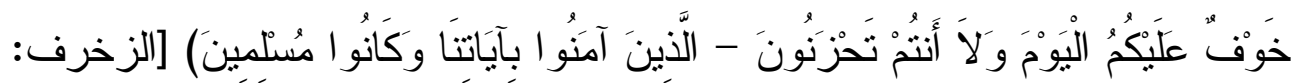

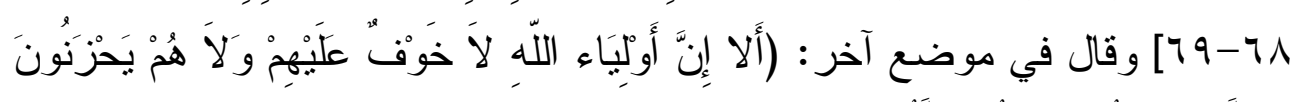

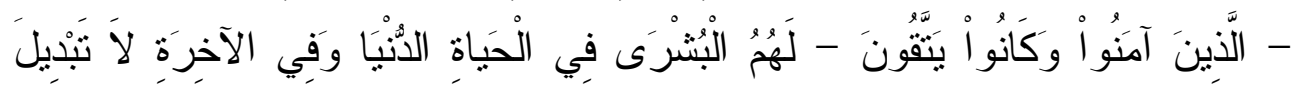

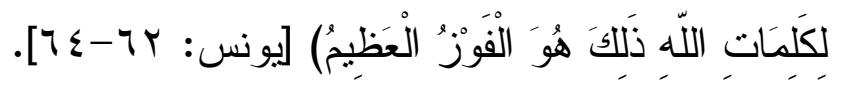
و السر في هذا الأمن الذي يشمل الله به عباده الأتقاء، أن قلوبهم كانت في

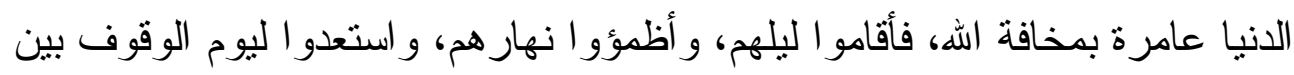

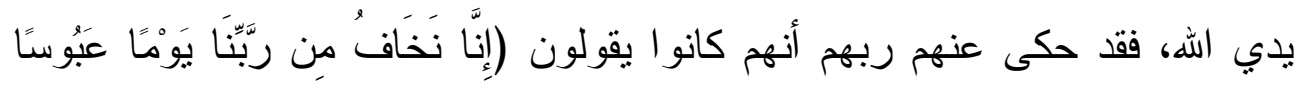

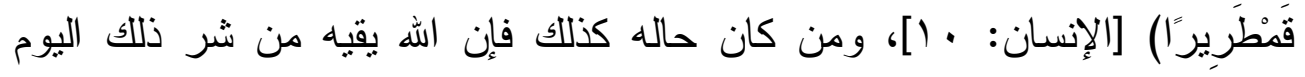

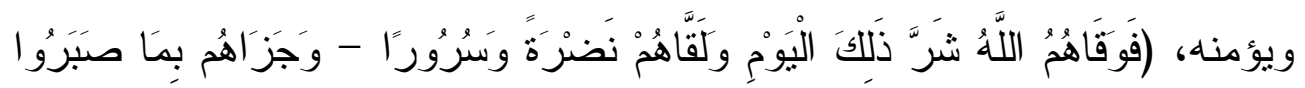

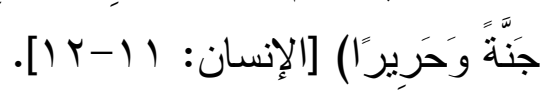

وفي الحديث الذي يرويه أبو نعيم في الحلية عن شداد بن أوس أن رسول الله

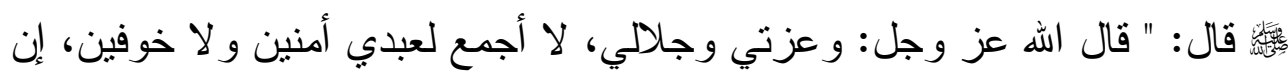

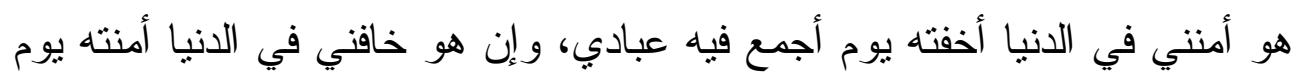
أجمع فيه عبادي "( أ). وكلما كان العبد أكثر إخلاصاً لربه تبارك وتعالى كان أكثر أمناً في يوم

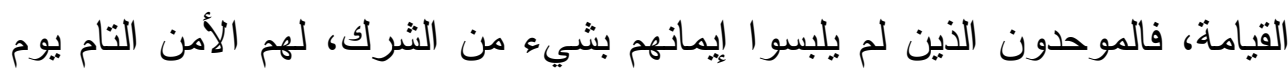


القيامة، يدلك على هذا جو اب إبر اهيم لقومه عندما خوفوه بأصنامهم، فأجابهم قائلاً:

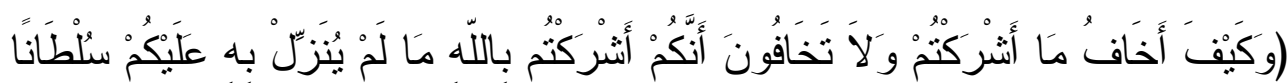

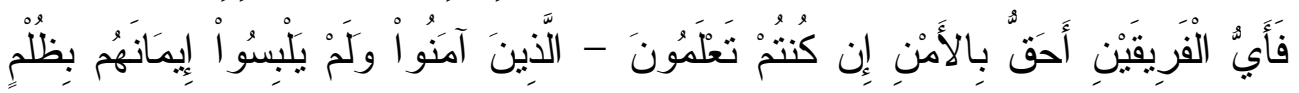

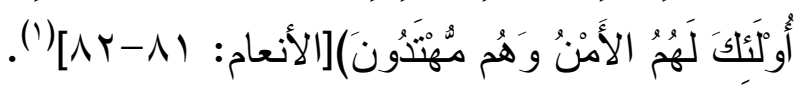

\section{-ظل عرش الرحمن و الجديرون به}

ومن نسائم الرحمات لعباد الهه المؤمنين ظل عرشه سبحانه، يقول الحق

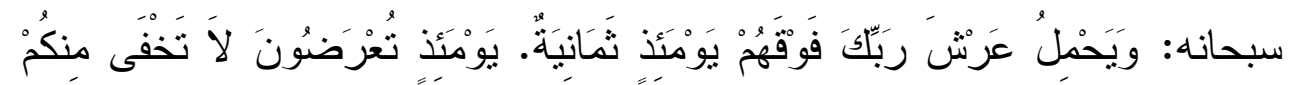

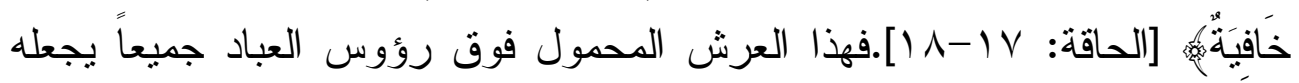
الحق سبحانه واحة للرحمة لعباده المؤمنين يستظلون تحتها وتقيهم حر هذه الثمس التي اقتربت من الرؤوس تحترق منها الأجساد ونتوى من لهيبها لهنها الأبدان. روى البخاري ومسلم في صحيحيهما عن أبي هريرة رضي الله عنه قال: قال رسول اله s.

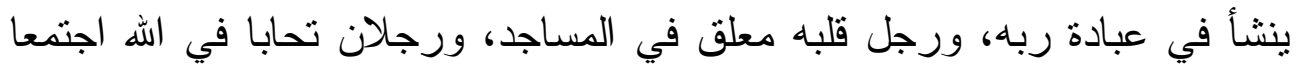
عليه وتقرقا عليه، ورجل طلبته امرأة ذات منصب وجمال فقال: إني أخاف الله، ولها ورجل تصدق أخفى حتى لا تعلم شماله ما تتفق يمينه، ورجل ذكر اله خالياً

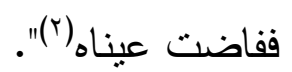

إنهم أصحاب الهمم العالية، و العزائم الصادقة، الذين تمثلت فيهم عقيدة الإسلام، وقيمه الفاضلة ، أو قاموا بأعمال جليلة، لها في مقياس الإسلام وزن كبير.فمن هؤ لاء: - ماء:

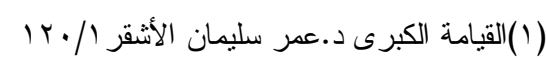

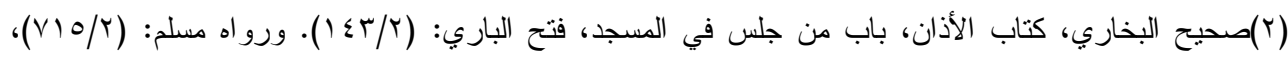

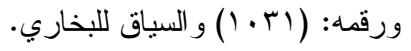


الإمام العادل، الذي يملك القوة والسلطان، ولكنه لم يطغ، و أقام العدل بين

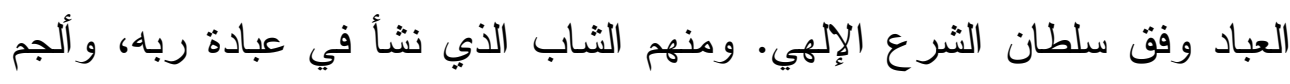
نفسه بلجام التقوى، وردع النفس و الهوى، فعاش عمره طاهر الثهاً نقياً. ومنهم عُمّار

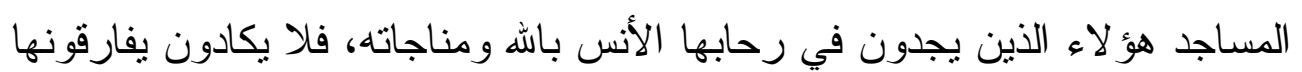

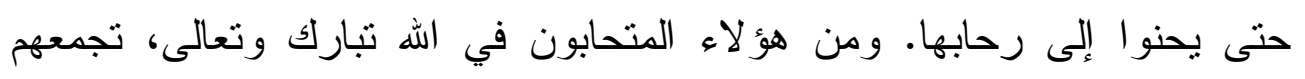

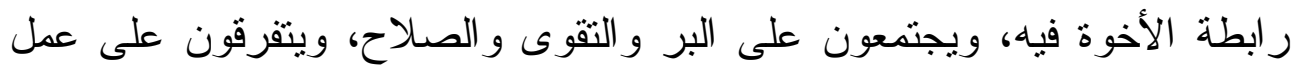

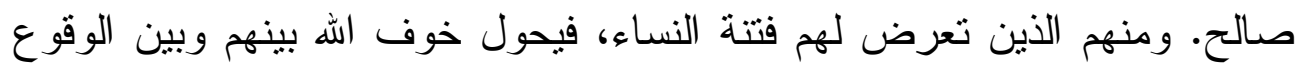
في الفاحشة. ومنهم المنفق الذي يخلص في دينه لله، فيخفي الصدقة حتى عن نفس لفهاه.

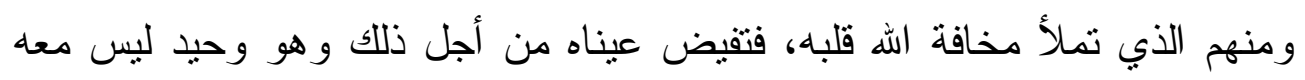

وقد جاءت نصوص كثيرة تدل على إظلال اله للمتحابين فيه في ظل العرش

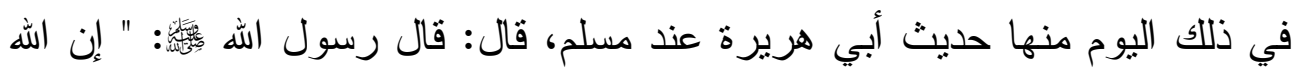

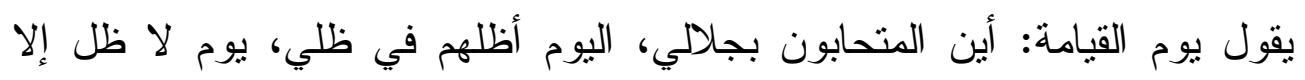
ظلي"(r).

وفي معجم الطبراني الكبير ومسند أحمد، وصحيح ابن حبان، ومستدرك

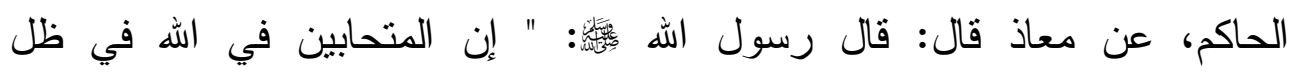

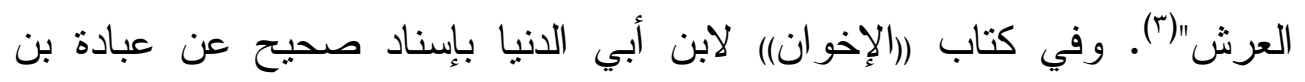
الصامت، عن رسول اله ؛

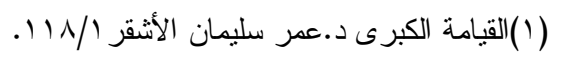

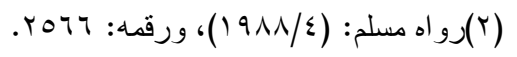

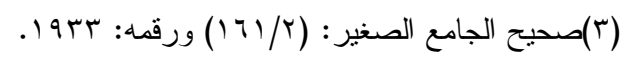


القيامة الكبرى (مشاهد ووقائع، دروس وعبر)

أظلهم في ظل العرش يوم لا ظل إلا ظلي "( ). و الإظلال في ظل العرش ليس مقصوراً على السبعة الدذكورين في الحديث،

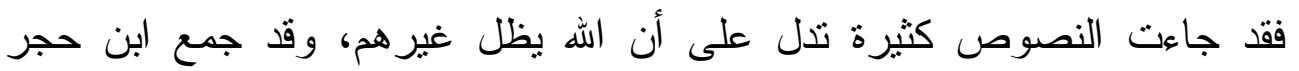
العسقلاني الخصال التي يظل الهه أصحابها في كتاب سماه: (معرفة الخصال

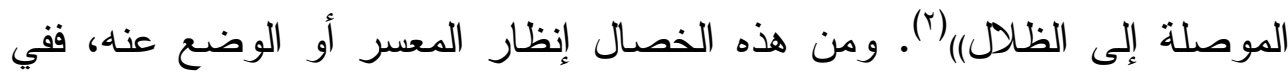

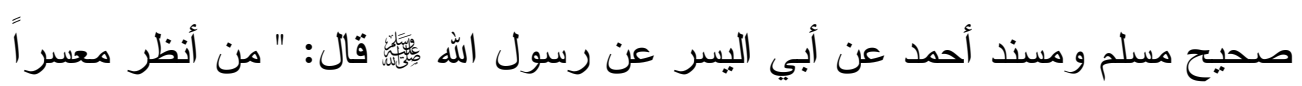
أو وضع عنه، أظله الهه في ظله "(").

وفي مسند أحمد وسنن الدارمي بإسناد صحيح عن أبي قتادة عن رسول اله فال: "من نفس عن غريمه أو محا عنه، كان في ظل العرش يوم القيامة"(؛). إنهم

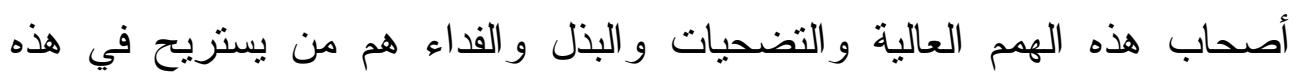
الواحة الغناء تحت ظل عرش الرحمن. الحوض

من نسائم الرحمات في هذا الموقف العصبب الحوض.الذي أكرم الحق -

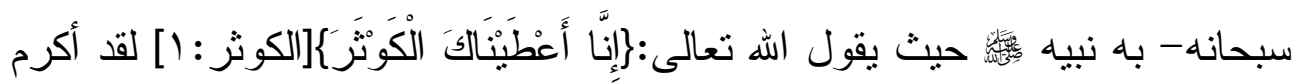
الحق سبحانه نبيها بالحوض المورود إنه الكوثز الذي أكرم الله به عبده ورسوله محمداً

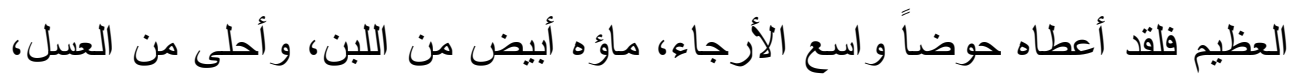

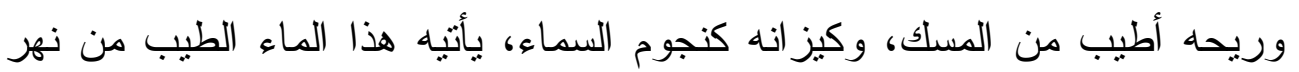

$$
\begin{aligned}
& \text { (1) (1) (1) (1) (1) ). }
\end{aligned}
$$

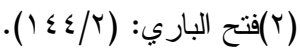

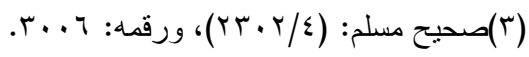

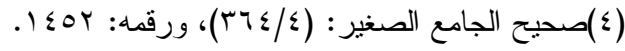


القيامة الكبرى (مشاهد ووقائع، دروس وعبر)

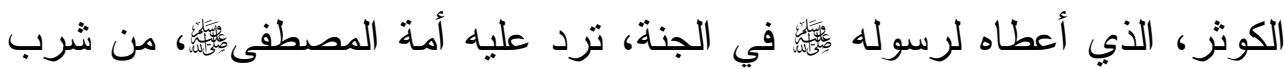
منه شربة لا يظمأ بعدها أبداً.

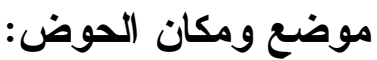

وقد اختلف أهل العلم في موضعه فذهب الغزالي و القرطبي إلى أنه يكون قبل

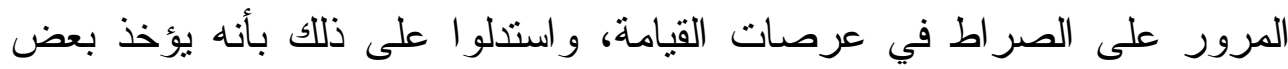

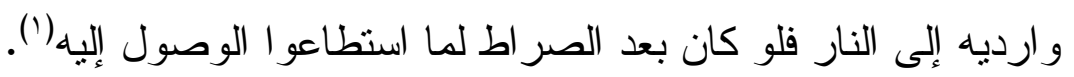
و استظهر ابن حجر أن مذهب البخاري أن الحوض يكون بعد الصراط، لأن

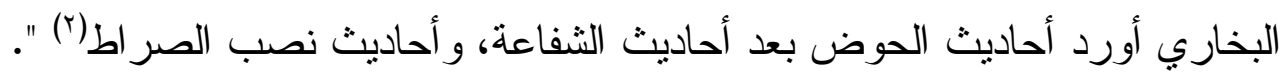
وما ذهب إليه القرطبي أرجح، وقد استعرض ابن حجر أدلة الفريقين في كتابه

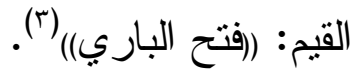

هذا وإن الأحاديث الواردة في الحوض متو اترة، لا شكك في تو اترها عند أهل

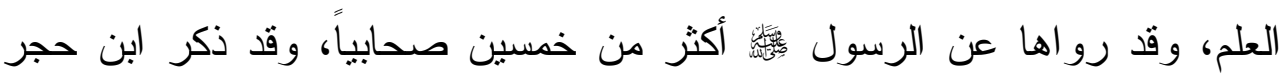

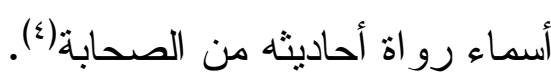
ونحن نسوق هنا بعض هذه الأحاديث التي أوردها الخطيب التبريزي في

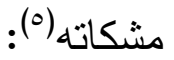
1- عن عبد اله بن عمرو، قال: قال رسول الله 
القيامة الكبرى (مشاهد ووقائع، دروس وعبر)

وزو اياه سواء('). ماؤه أبيض من اللبن، وريحه أطيب من المسك، وكيز انه كنجوم

السماء، من يشرب منها فلا يظمأ أبداً ". متفق عليه(؟).

ץ- وعن أبي هريرة قال، قال رسول الله

عدن لهو أثدُّ بياضاً من التلج، وأحلى من العسل باللبن، و لآنيته أكثر من عدد النجوم، و إني لأصد الناس عنه كما يصد الرجل إيل الناس عن حوضه ". قالو ا: با رسول الله ! أتعرفنا يومئذ؟ قال: " نعم لكم سيماء() ليست لأحد من الأمم، تردون

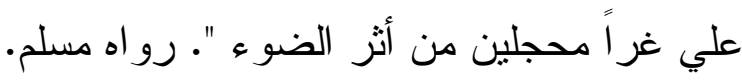
r- وفي رواية له (9) عن أنس. قال: " ترى فيه أباريق الذهب و الفضة كعدد نجوم السماء ". ع- وفي أخرى له عن ثوبان، قال: سئل عن شر ابه. فقال: " أثند بياضاً من اللبن، و أحلى من العسل يغت(0) فيه ميز ابان يُمدَّانه من الجنة، أحدهما من ذهب

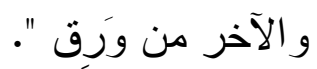

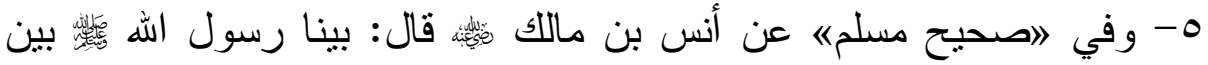
أظهرنا في المسجد إذا أغفى إغفاءةً ثم رفع ر أسه متبسمًا، قلنا: ما أضحك يا رسول

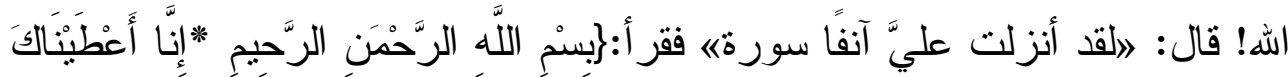

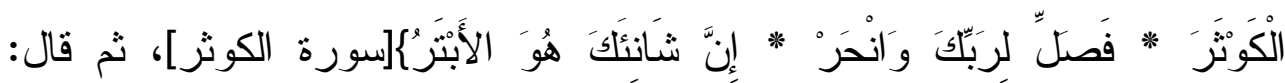
״أتدرون ما الكوثز؟ قلنا: الله ورسوله أعلم، قال: 》فإنه وعدنيه ربي عز وجل،

(1) (1) (ب مربع لا يزيد طوله عن عرضه شيئاً.

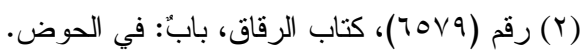

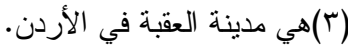

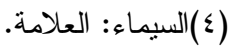

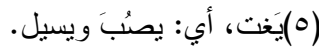


عليه خير كثير، وهو حوض ترد عليه أمتي يوم القيامة، آنيته عدد النجوم في

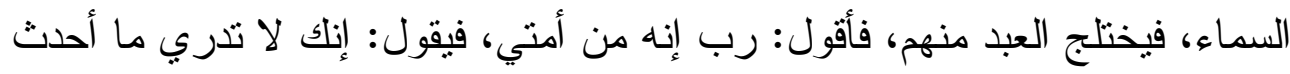
بعدكه (')

و المعنى في هذا الحديث - كما ذكر شارح 》الطحاويةه - أن نهر الكوثر -

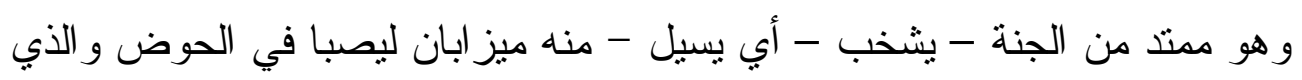

$$
\text { هو في العرصات(؟). }
$$

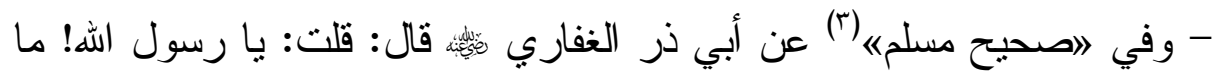
آنية الحوض؟ قال: اوالذي نفس محمد بيده، لآنيته أكثر من عدد نجوم السماء

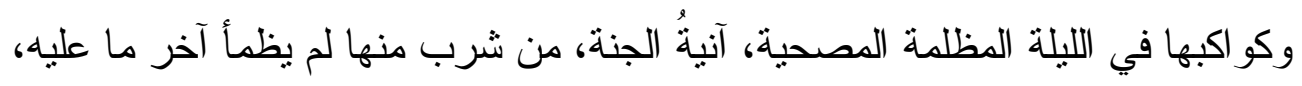

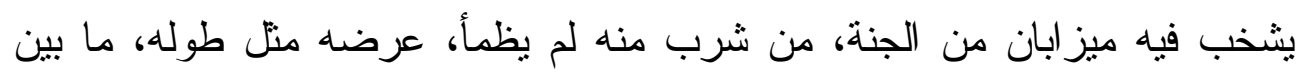

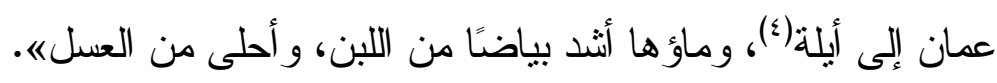

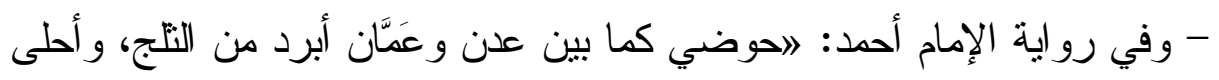

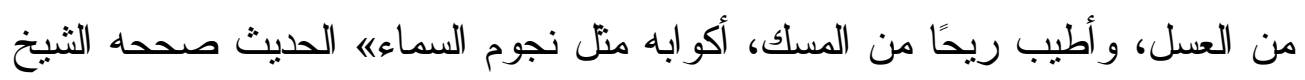

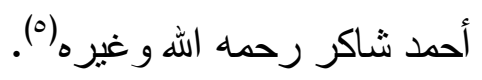

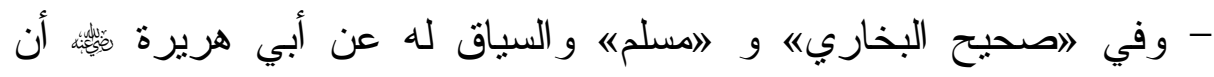
رسول الله

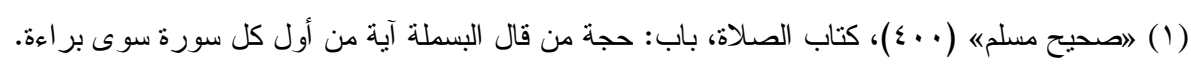

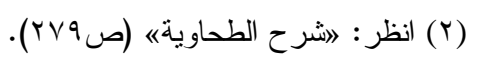

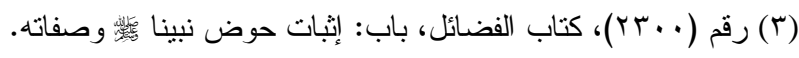

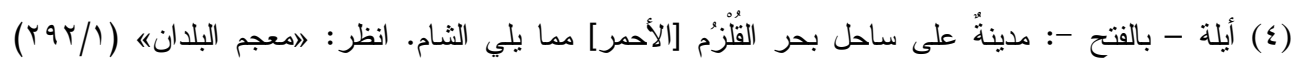
للحموي.

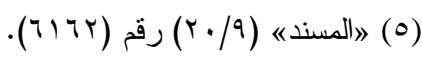


القيامة الكبرى (مشاهد ووقائع، دروس وعبر)

إبلَ الرجل عن إبله، قالوا: يا نبي الله! تعرفنا؟ قال: نعم، لكم سيمًا ليست لأحدٍ

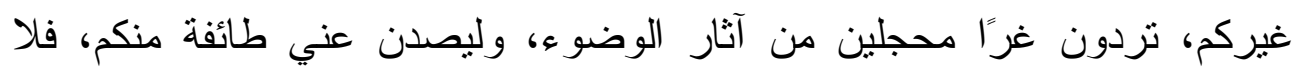

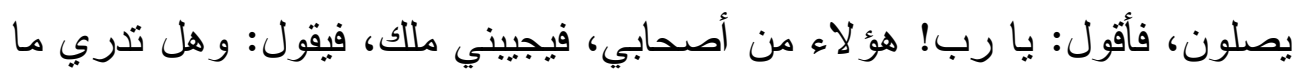

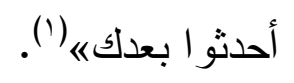

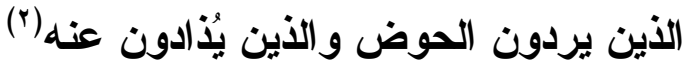

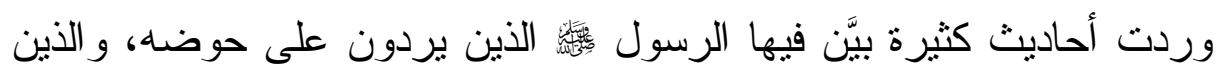

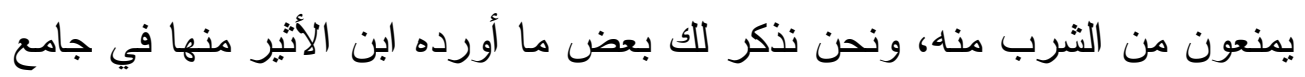

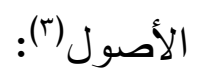

1- روى البخاري ومسلم عن عبد الله بن مسعود رضي الله عنه قال: قال رسول اله أس

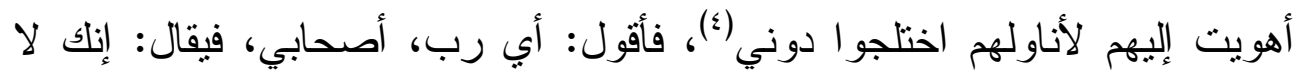

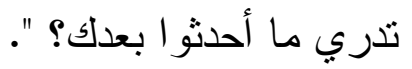

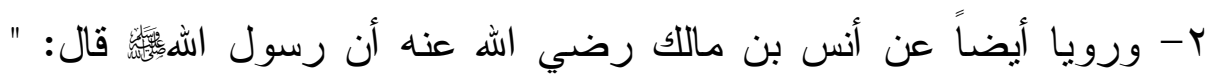

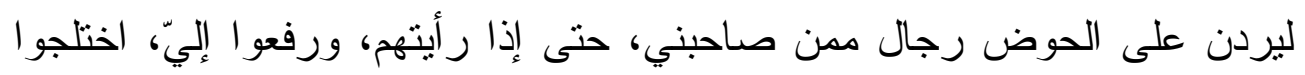

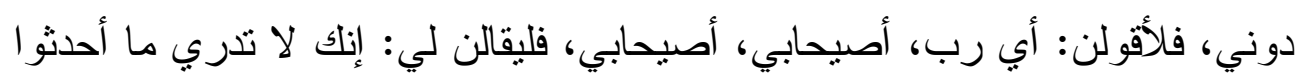

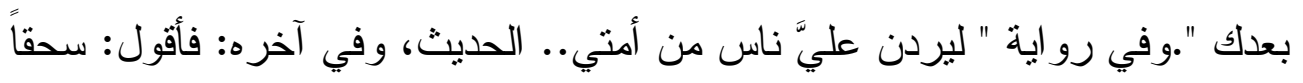

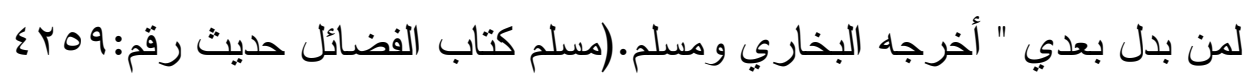

(1) (البخاري" (1010)، كتاب الرقاق، باب: في الحوض، 》إمسلمه (Y (Y)، كتاب الطهارة، باب: استحباب إطالة

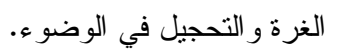

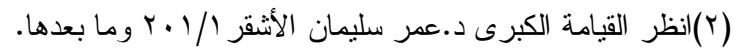

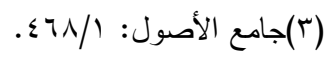

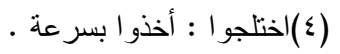


ז- ورويا عن أبي حازم رحمه الله عن سهل بن سعد رضي الله عنه، قال:

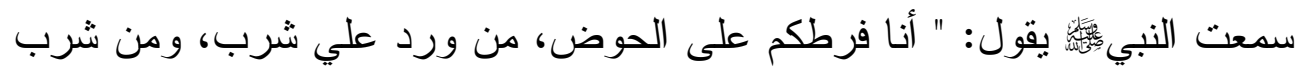

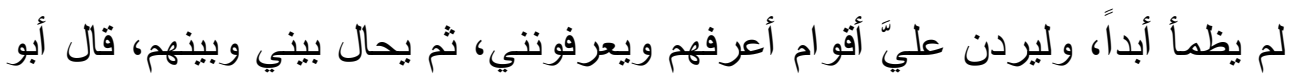

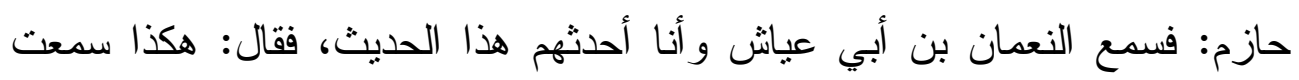

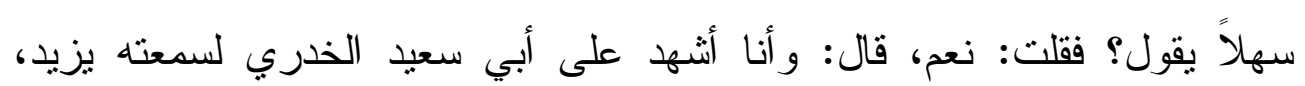

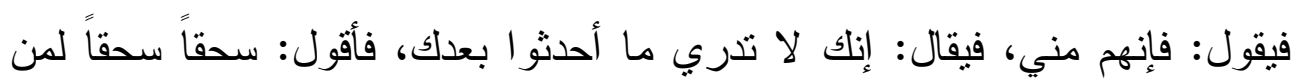

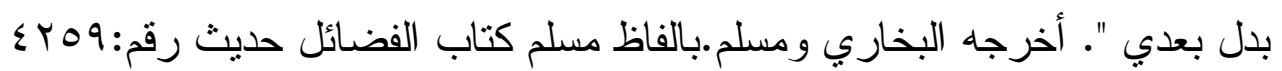

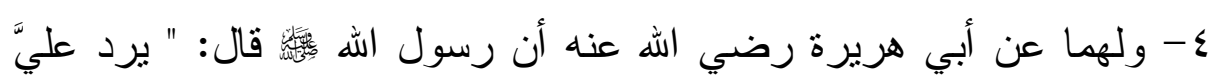

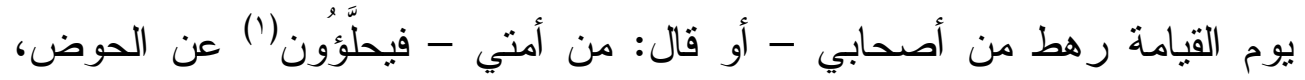

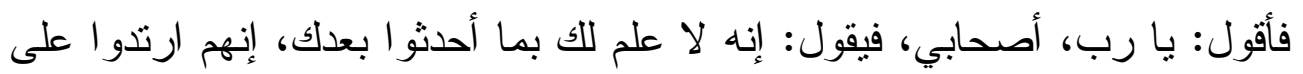

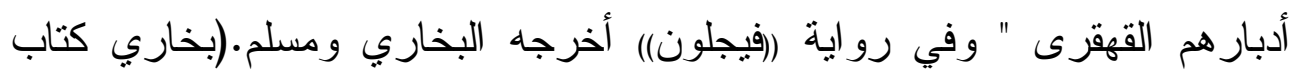
الرقاق حديث رقم:119 ـ 7

وللبخاري: أن رسول الله

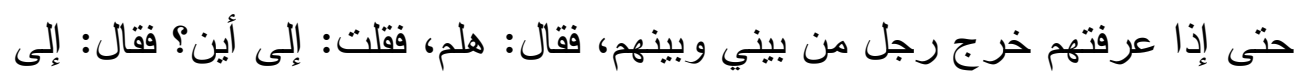
النار والله، فقلت: ما شأنهم؟ فقال: إنهم قد ارتدوا على بلى أدبارهم القهقرى، ثم إذها زمرة أخرى، حتى عرفتهم خرج رجل من بيني وبينهم فقال لهم: هلم، قلت: إلى لى لهان

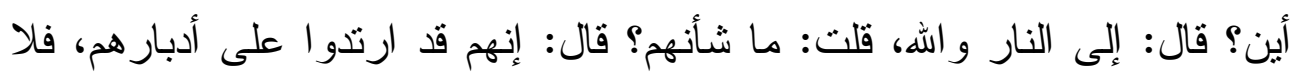
أر اه يخلص منهم إلا مثل همل النعم " (؟).

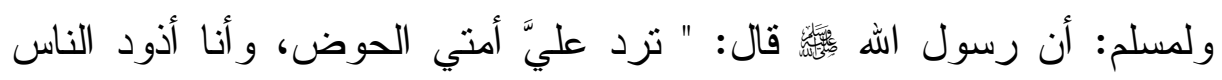

$$
\begin{aligned}
& \text { (1) (بلحؤون، أي: يدفعون ويطر دون. } \\
& \text { (Y) همل النعم: الإبل الضالة. و المعنى أن الناجي منهم قليل. } \\
& -1 \cdot v-
\end{aligned}
$$


عنه، كما يذود الرجل إبل الرجل عن إبله، قالو ا: يا نبي الله تعرفنا؟ قال: نعم، لكم

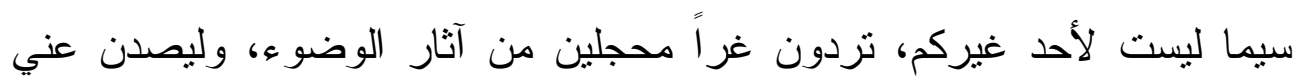

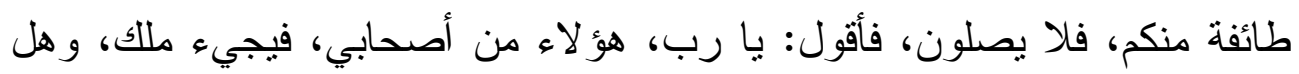

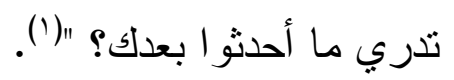

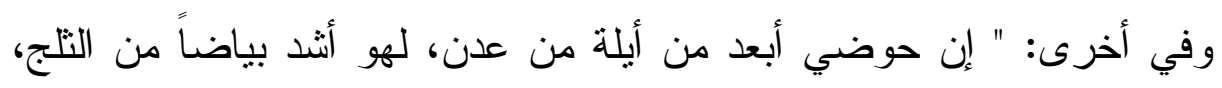

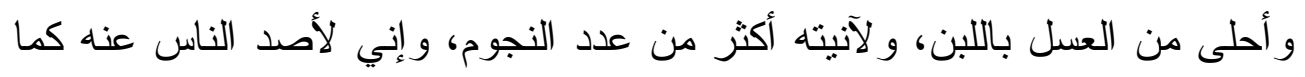

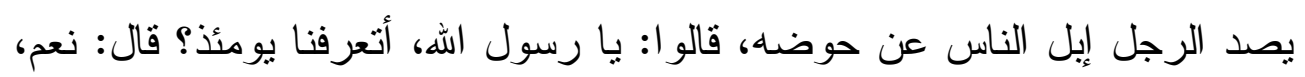

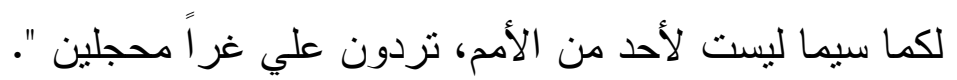

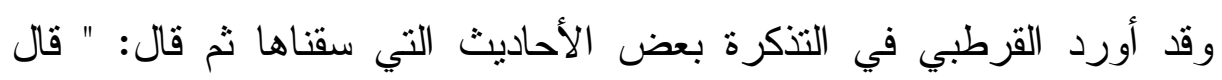

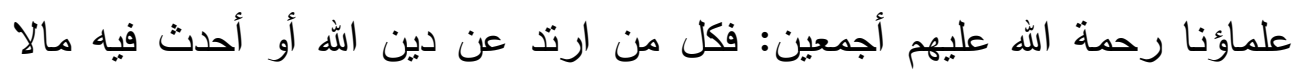

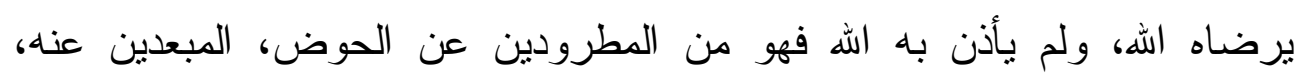

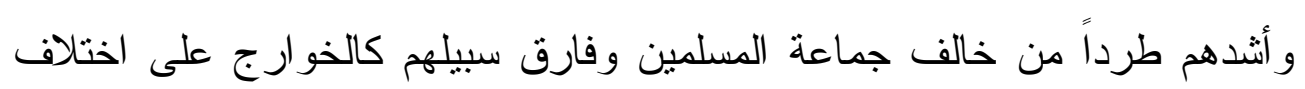
فرقها، و الرو افض على تباين ضلالها، و المعتزلة على أصناف أهو ائها، فهؤلاء

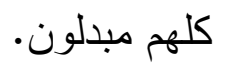
وكذلك الظلمة المسرفون في الجور وتطيس الحق وقتل أهله و إذلالهم و المعلنون بالكبائر المستخفون بالمعاصي وجماعة أهل الزيخ و الأهو اءو والبدع. ثم البعد قد يكون في حال، ويقربون بعد المغفرة إن كان التبديل في الأعمال، لهال

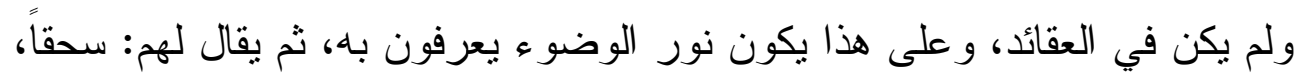

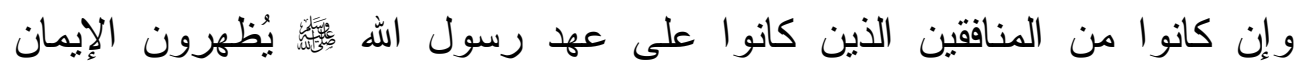


القيامة الكبرى (مشاهد ووقائع، دروس وعبر)

ويسرون الكفر فيأخذهم بالظاهر ، ثم يكثف لهم الغطاء فيقال لهم: سحقاً سحقاً، ولا

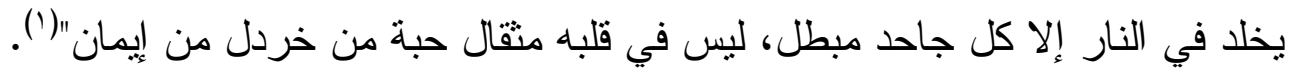

الثفاعة العظمى

نقصد بالثفاعة العظمى تلك المكانة و المنزلة التي خص الله بها نبيه من بين

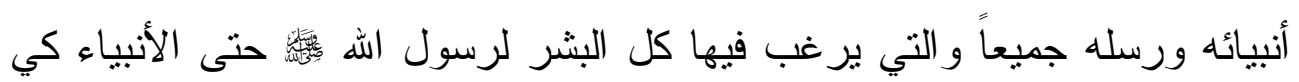

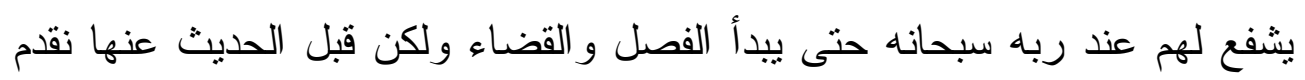
لها بتوطئة لتعريف الثنفاعة و أنو اعها بإيجاز لحاجة سياق الحديث إلى ذلك الكي

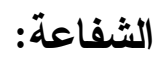

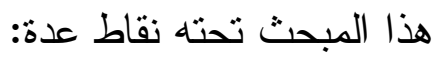

$$
\text { التعريف اللغوي }
$$

يقول الر اغب في مفرداته: الثنفع: ضم الثنيء إلى منله، ويقال للمشفوع: شفع،

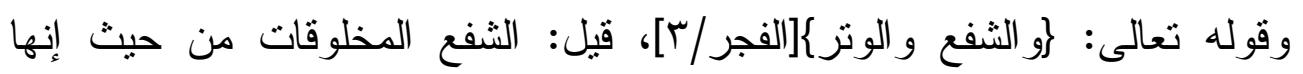
مركبات، كما قال: (رومن كل شيء خلقنا زوجين\{[الذاريات/9 ؟]، و الوتر : هو الله

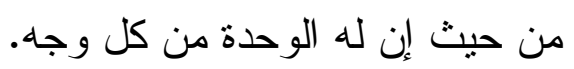

و الثنفاعة: الانضمام إلى آخر ناصر الله وسائلا عنه، و أكثر ما يستعمل في انضمام من هو أعلى حرمة ومرتبة إلى من هو أدنى. ومنه: الثنفاعة في القيامة.

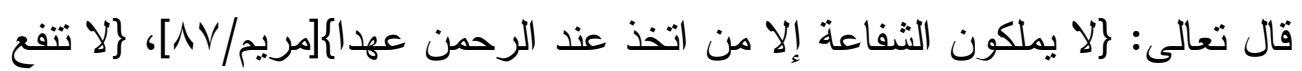

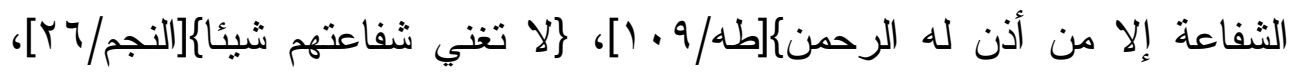

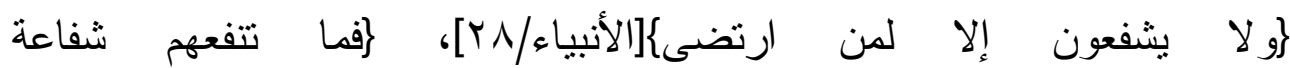

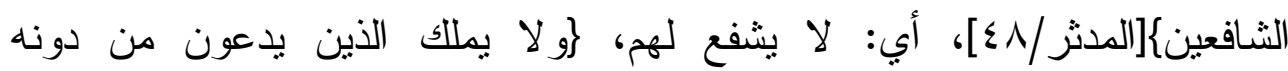

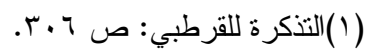




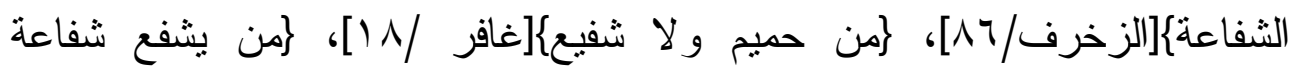

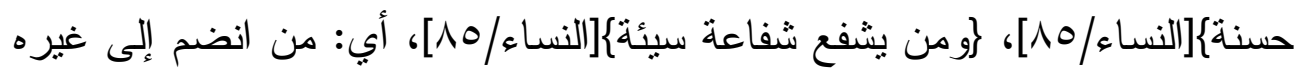

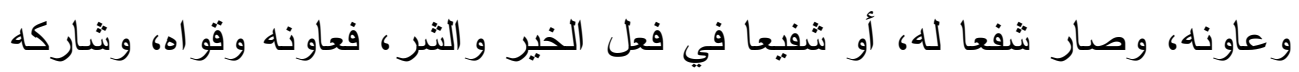

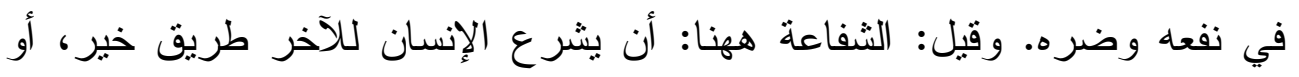
طريق شر فيقتدي به، فصار كأنه شفع له (1).

\section{أنواع الثثاعة}

1- الثفاعة العظمى: وهي المقام الدحمود، الذي برغب الأولون و الآخرون

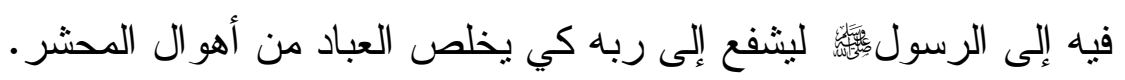
r- شفاعته في الإذن للمؤمنين بدخول الجنة. r- الثفاعة في أقو ام ياخلون الجنة بغير حساب. ع - شفاعة الرسول:

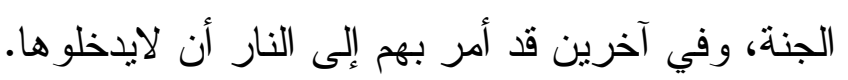
0- الثفاعة في أهل الذنوب من الموحدين الذين دخلوا النار. צ- شفاعته : ثو اب أعمالهم. V-ثفاعة غير الأنبياء من الصديقين و الثهداء و الإخوان و الأصدقاء. الثفاعة العظمى: لقد جمع الحق سبحانه الأولين و الآخرين في صعيد واحد و الناس بين فريقين

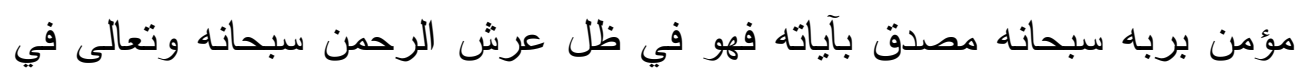


القيامة الكبرى (مشاهد ووقائع، دروس وعبر)

هذا الموقف، وكافر بربه ومكنب لرسله فهو في كربه وغمه وحزنه و همه تحت حر الثمس ولهيبها يشوى الجلود و العرق تغرق منه الأبدان.

ويطول الموقف على العباد في يوم كان مقداره خمسين ألف سنة، ويشتد بهر

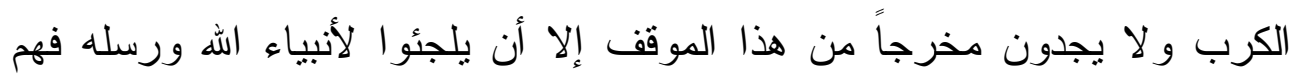

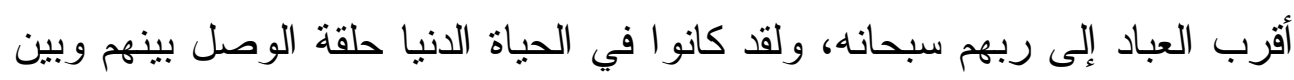

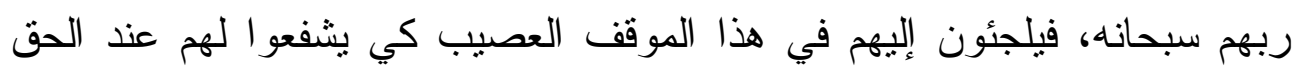

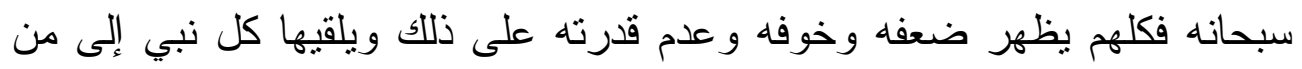

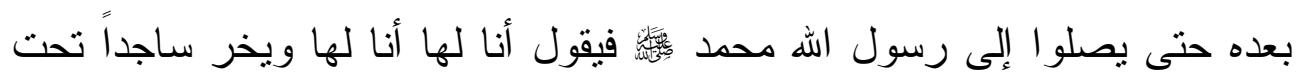

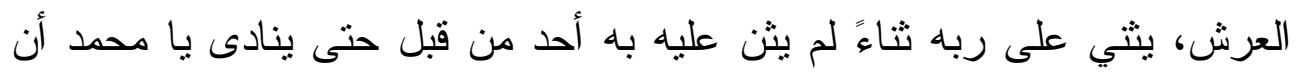
ارفع رأسك وسل تعطه و اثففع تشفع.

فهذه هي الثنفاعة العظمى التي أعطاها اله لنبيه وهو الدقام الدحمود الذي

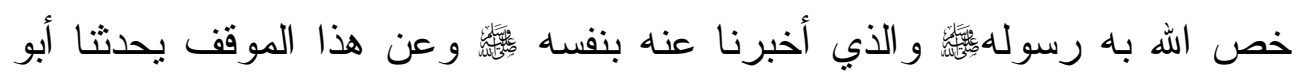

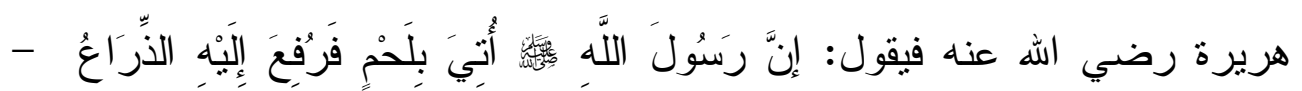

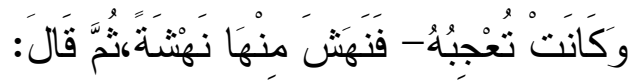

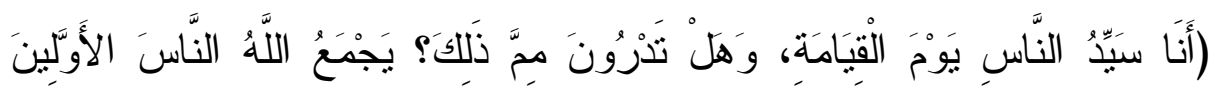

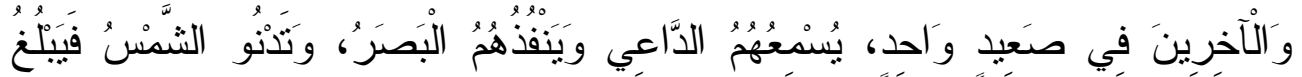

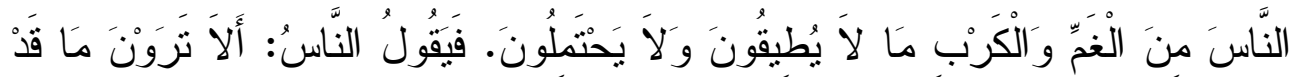

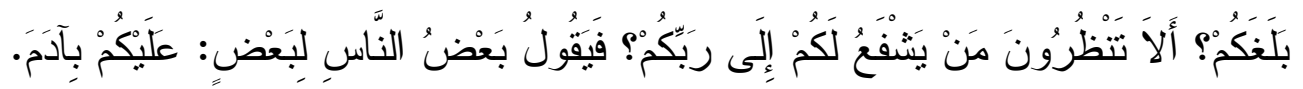

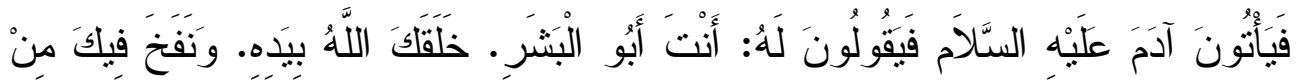

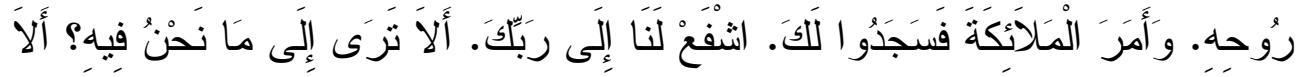

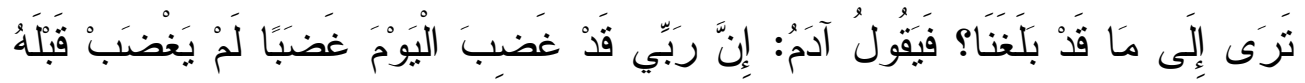




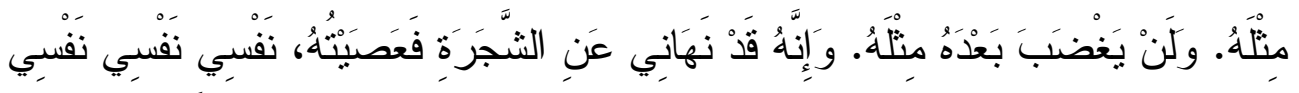

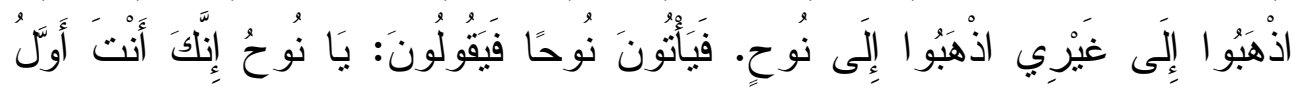

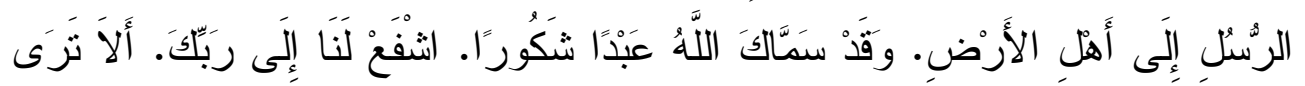

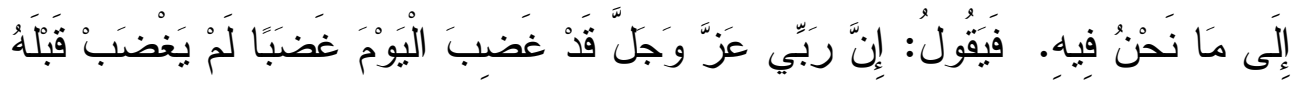

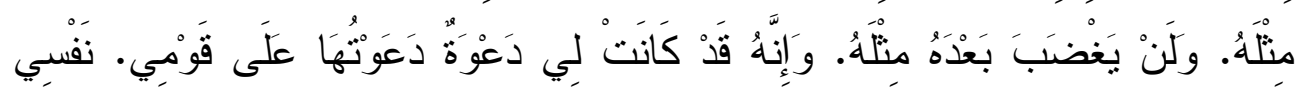

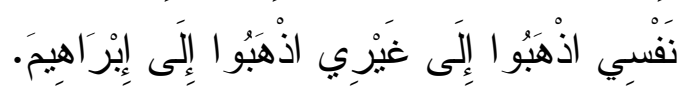

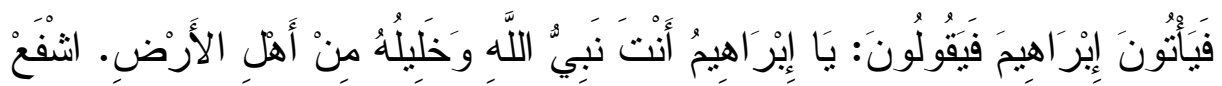

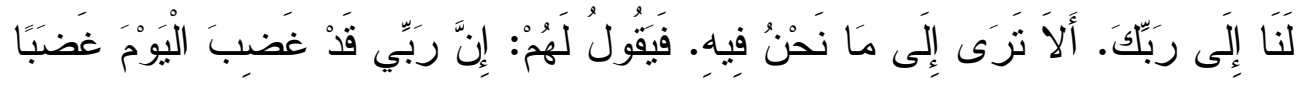

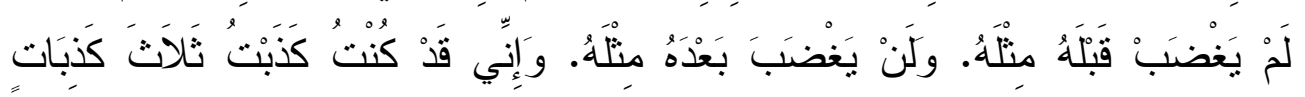

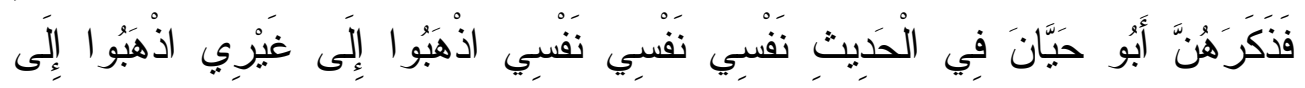
مُوسنَى.

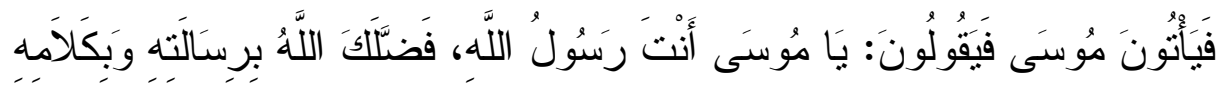

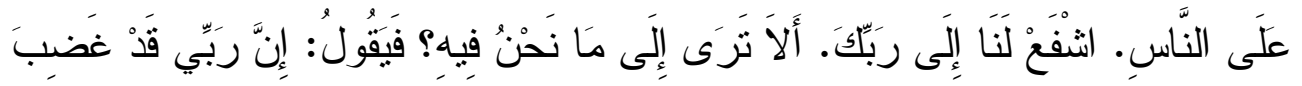

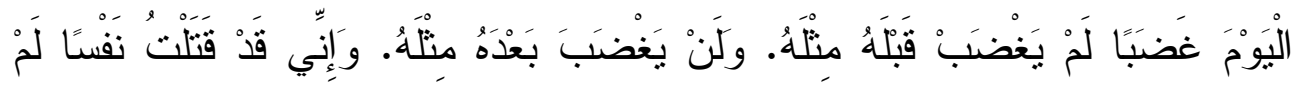

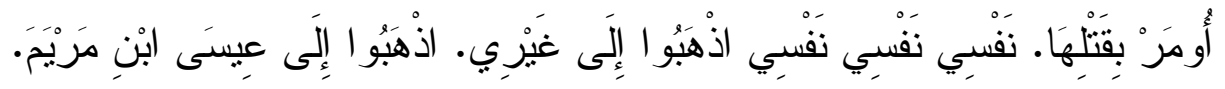

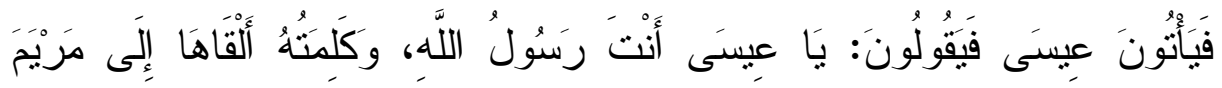

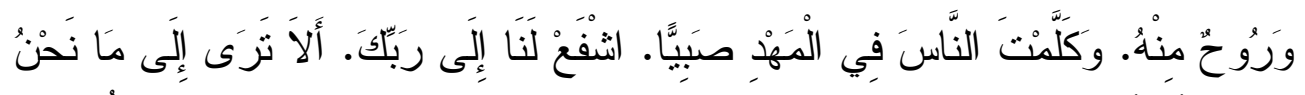

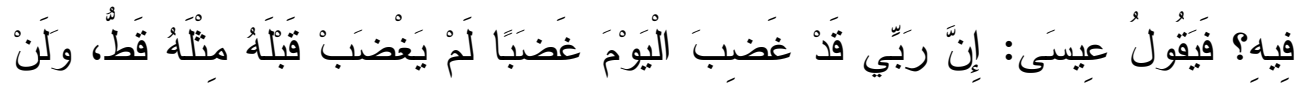

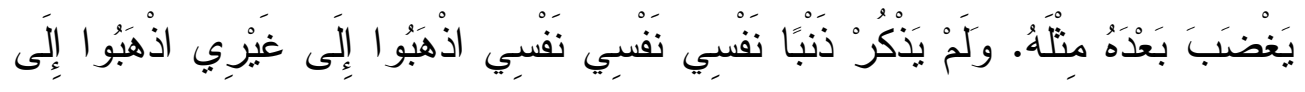
مُحَمَّد.

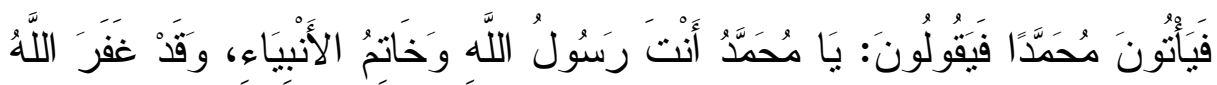




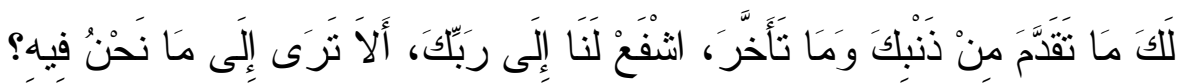

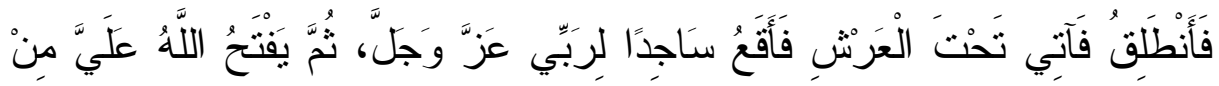

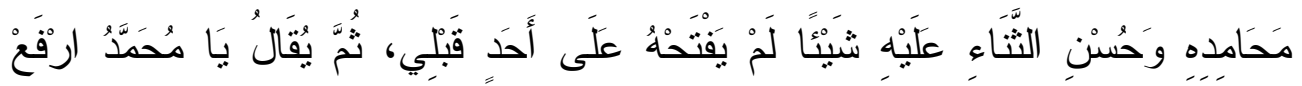

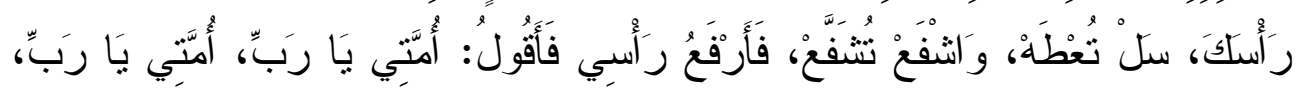

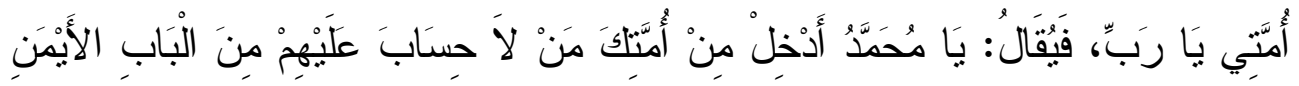

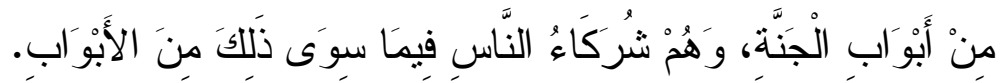

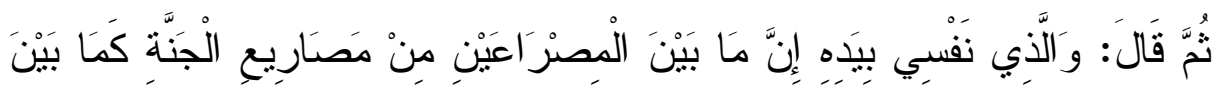

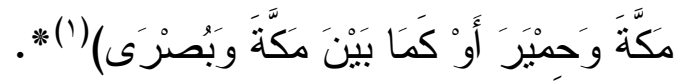

إن الكرب في هذا اليوم عظيم وإن الغم والهم و الفزع و الخوف تنخلع من أجله القلوب من الصدور، و الأنبياء يفرون من موقف الثفاعة في هذا اليوم حيث يقول كل منهم نفسي نفسي إلا رسول الله الأنبياء رسالته وما بعث به إلى قومه حيث يقول الحق سبحانه:

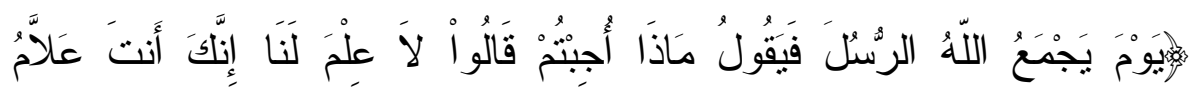

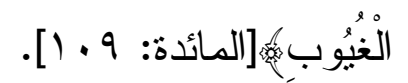

ومن فضل الله على البشرية جمعاء تلك المكانة التي أعطاها الهه لرسوله فلا يفزع من موقف الثفاعة أمام الله سبحانه وتعالى، فكل الأنبياء يقولون نفسي نفسي إلا رسول اله ئس فإنها يقول أمتي أمتي، وهذا من فضل الله على عباده، ومن

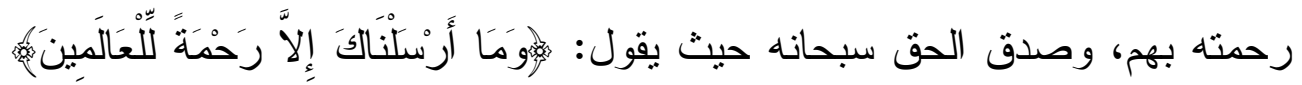

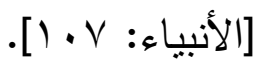
ويشفع رسول الله ( ) (البخاري. كتاب تفسير القر آن. حديث رقم بـ بـ. 
القيامة الكبرى (مشاهد ووقائع، دروس وعبر)

هول الموقف ومن شدة العذاب، وتعرف مصائر ها بعد طول انتظار ، وشدة معاناة فإما إلى جنات الخلد، أو إلى عذاب جهنم وبئس المصبر.

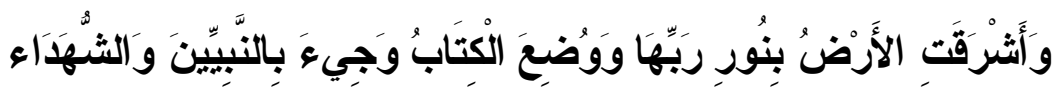

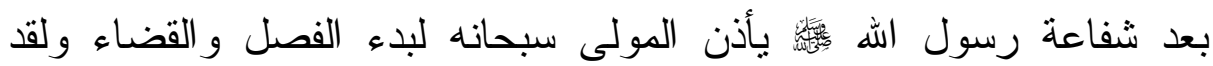
تناولت هذا الموقف آيات عدة وأحاديث كثيرة منها:

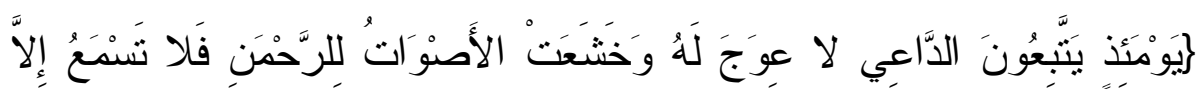

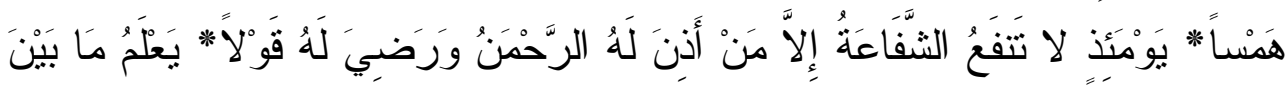

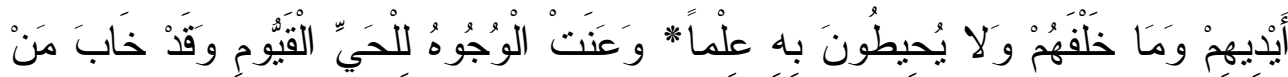

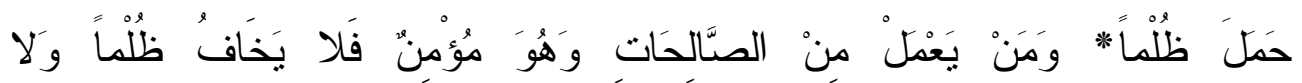

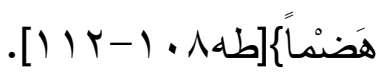

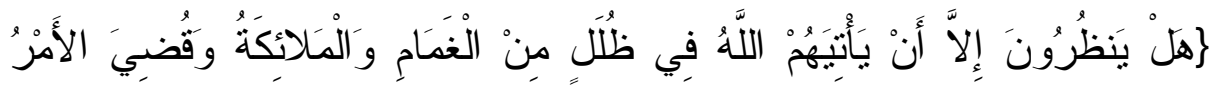

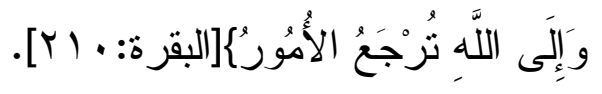

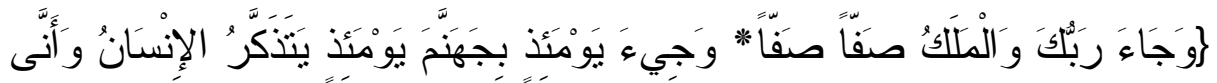

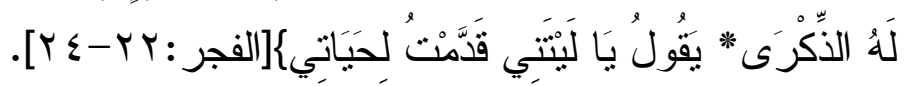
بمنتهى القوة يصور القرآن الكريم هذا المشهد من مشاهد يوم القيامة.إنه وصف دقيق، وتصوير حي يذيب الجلود، ويصهر العظام، وتتخع لهوله القلوب، بل تكاد تفارق الأجسام. ألا تزى كيف تعدد دولة ما لحشد كل قو اتها وطاقاتها وجحافلها في عرض عسكري مهيب لتلقي الرعب و الفزع في قلوب خصومها حين

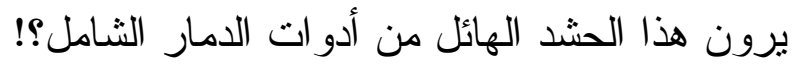
و هذا هو المشهد نفسه، لكن مع الفارق الضخم الكبير، أعني هذا هو العرض أله

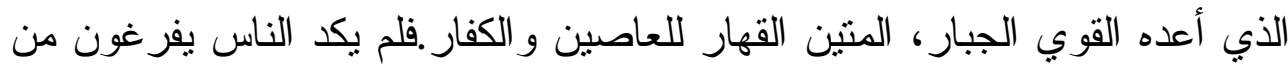


القيامة الكبرى (مشاهد ووقائع، دروس وعبر)

أرض تدك دكا و إذا هم بحشد إلهي رهيب ومهيب.

ما زلت تزى الناس سكارى. وما هم بسكارى، فإذا هم أمام موكب جليل عظيم

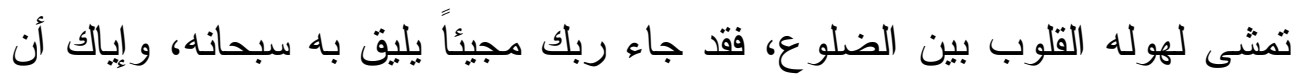
تؤول المجيء بشيء غير المجيء، فكل شيء في هذا اليوم فوق تصور العقول،

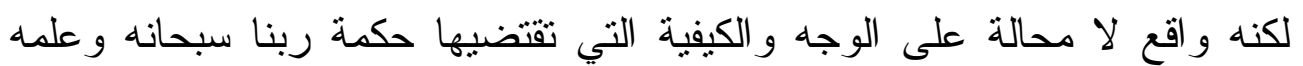
وقدرته! - مان

وجاء الملك صفا صفاً، في خشوع وخضوع، وعنت الوجوه للحي القيوم فلا

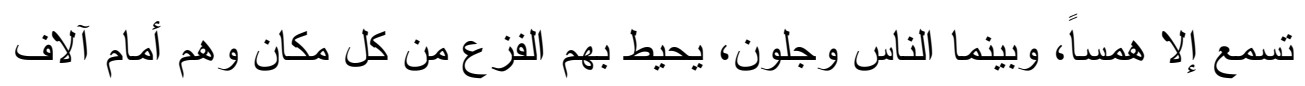

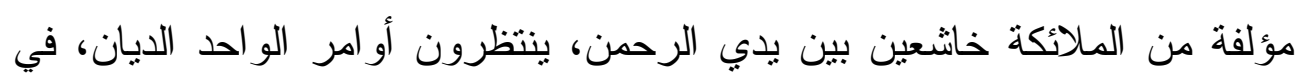

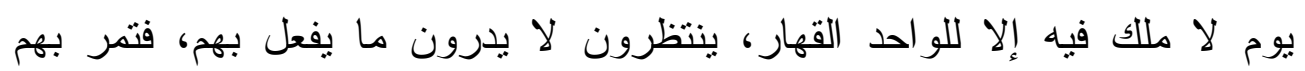

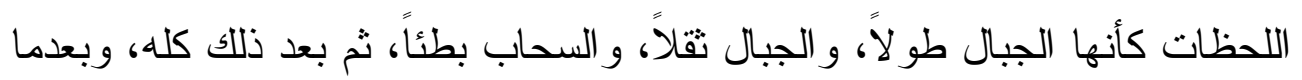

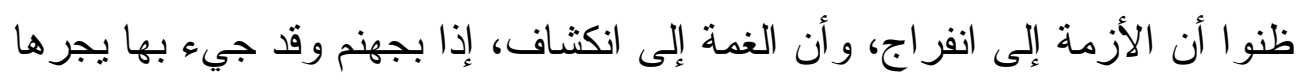

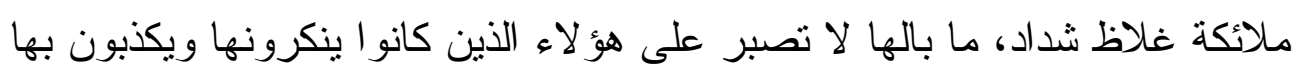
لم تصبر حتى يذهبو إليها فسار عت هي إليهم!

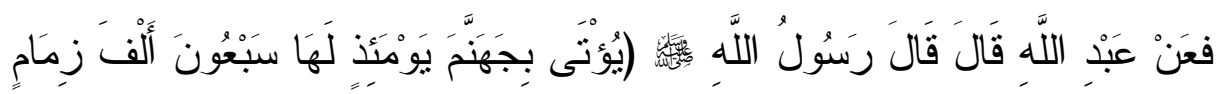

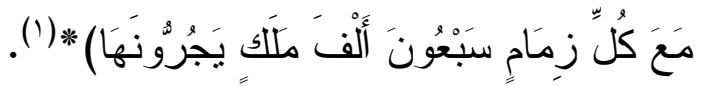
فهاهم، وها هي.وجهاً لوجه! فهل آن لهم أن يؤمنو ا؟ نعم. ربما ولكن لات هونات

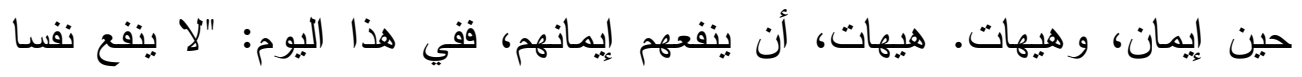

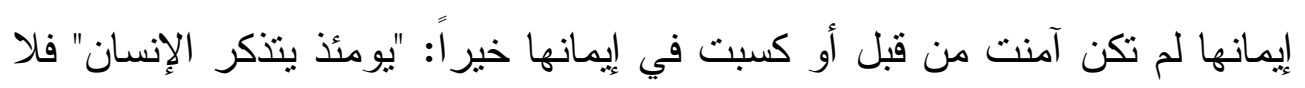

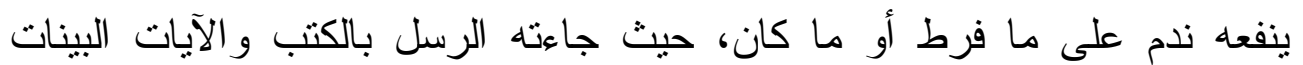

( (1) مسلم. كتاب الجنة ووصف نعيمها و أهلها. حديث رقم 0.V7. 
تخاطب عقله فيوصده، وتخاطب قلبه فيغلقه، تقتح سمعه وبصره فيغلقه "وأنى له

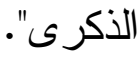

وحين يرى الهول شاخصاً، ويرى جهنم مقبلة تنتعجل وقودها من كفار الناس

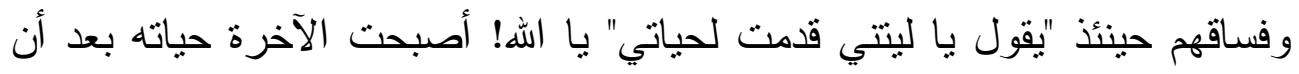

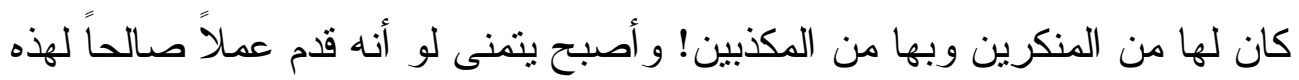

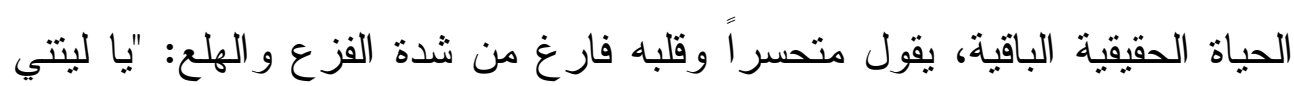

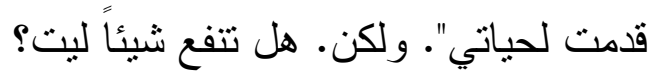
وفي موضع آخر حيث يقول تعالى: مهإِإذا جاءت الصاخة، يوم يفر المرء من

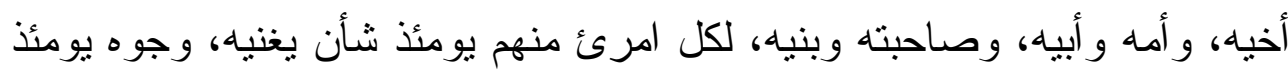

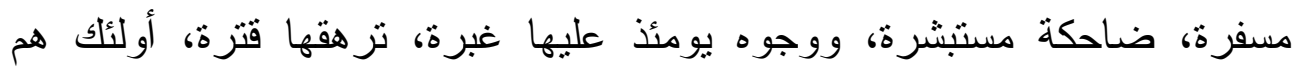

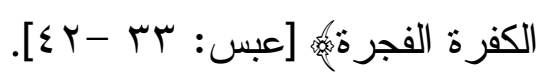

الصاخة: هي الصيحة تصم لثدتها، ومنه سميت القيامة الصاخة"(1). وقد سميت بهذا الاسم لما تحدثه من فزع وهلع يخلع القلوب، لبس فقط، بل ويسلخ الإنسان عن أقرب الناس إليه.!

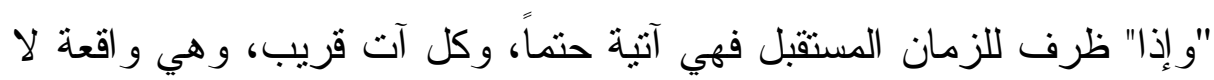
محالة كوقد سبق بيان ذلك- فإذا جاءت يفر المرء من أخيه وأمه و أبيه وصاحبته وبنيه، وإنما يفر الإنسان عادة من شيء يخافه على نفسه، فلم إذن يفر من هؤلاء

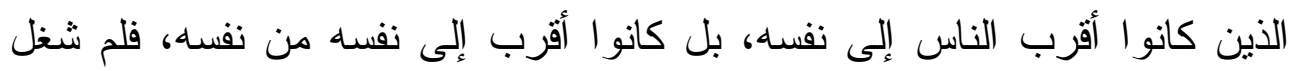

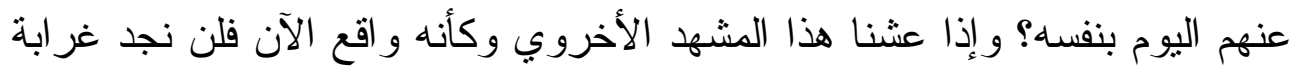

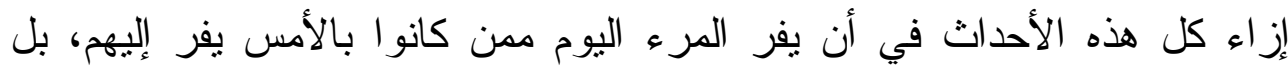


القيامة الكبرى (مشاهد ووقائع، دروس وعبر)

وممن كانو ا يؤثر هم على نفسه بروحه وماله ونفسه!

و لأن ما كان يحدث بالأمس القريب في الحياة الدنيا يختلف تماماً عما يحدث رهاث

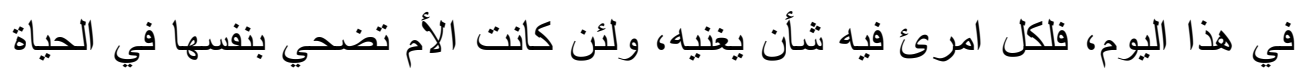

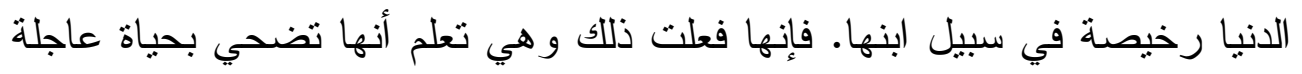

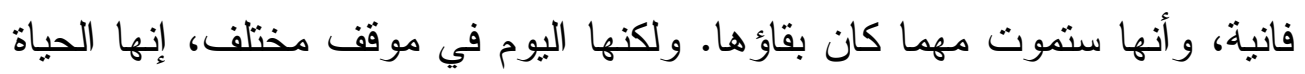

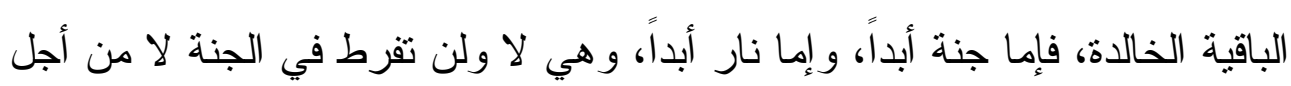

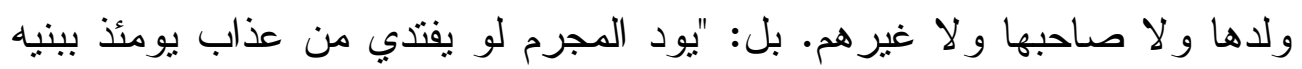

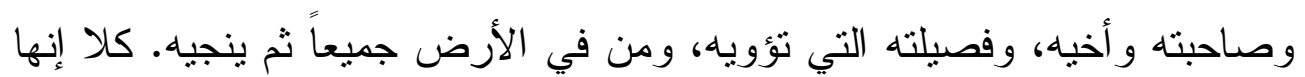
لظى.... ل

لقد أذن الحق سبحانه للفصل و القضاء بين عباده فإلى ساحات العرض و الفصل و القضاء

\section{ساحة العرض و الفصل و القضاء:}

إن ساحة الفصل والقضاء بين العباد في هذا اليوم منلاها كساحات القضاء في

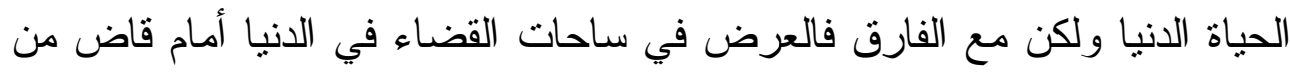
البشر بطلع على بعض جو انب القضية ويخفى عنه بعضها، ولكن العرض هنا فئا أمام

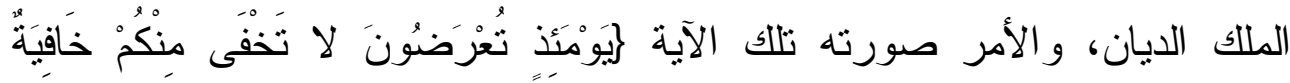

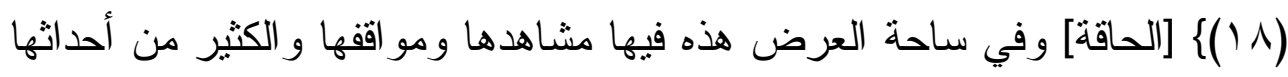
ومو اقفها سنحاول رسم صورة متكاملة لأحداثها ووقائعها من خلال هذه النقاط: - القواعد التي يتم على أساسها حساب العباد يوم القيامة:

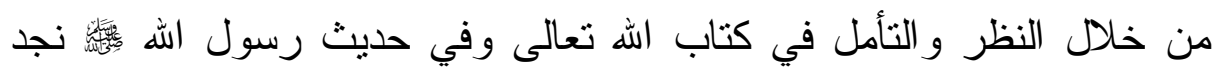

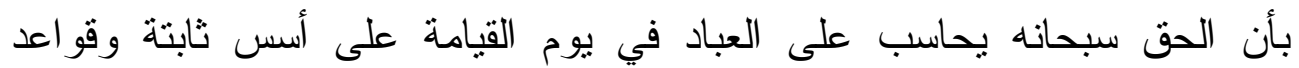


القيامة الكبرى (مشاهد ووقائع، دروس وعبر)

محددة، فلا ظلم في هذا اليوم و لا غبن، حيث يقول الحق سبحانه خوزونضع الموازين

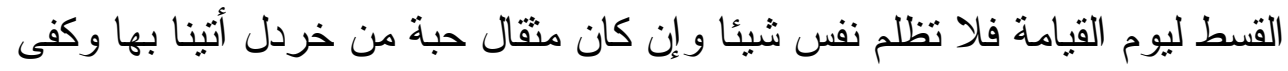

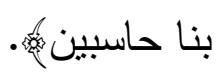

ولذلك فإنه من نظرتتا إلى موقف الحساب في يوم القيامة من المكن أن

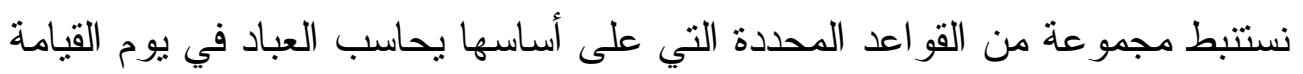

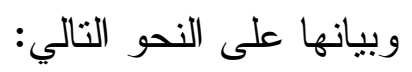

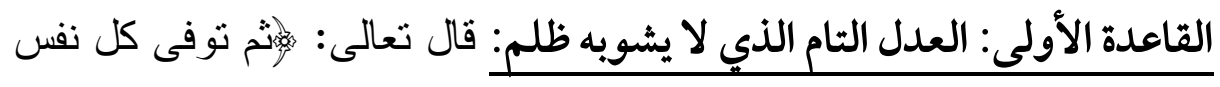

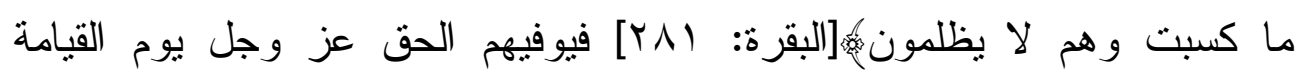

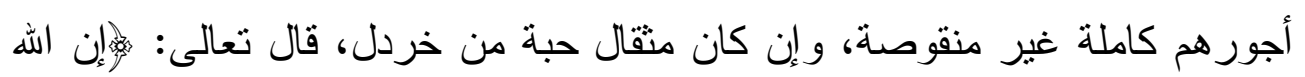

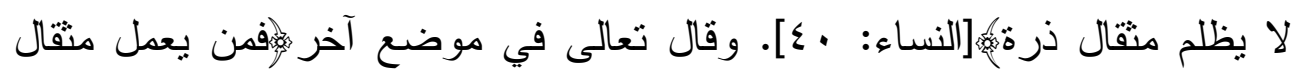

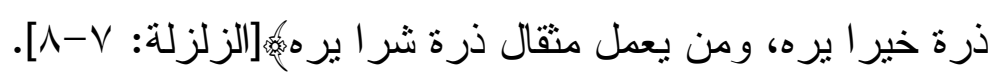

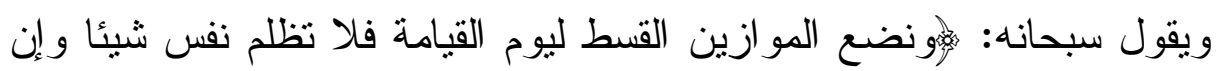

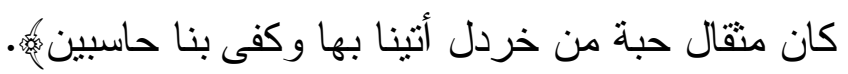

ثم يكون الجز اء الحق من الحق تبارك وتعالى مولهومن يعمل من الصالحات من

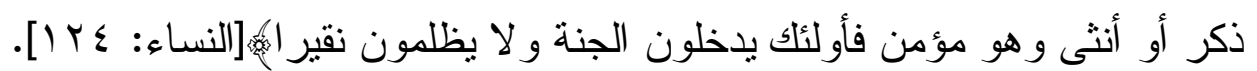

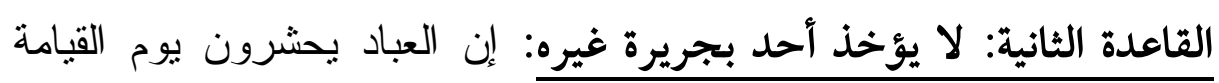

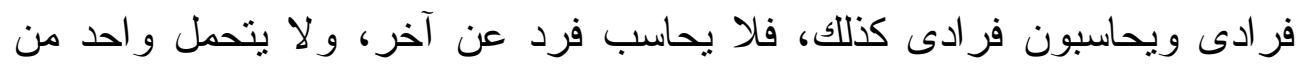

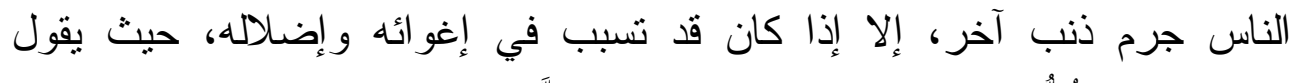

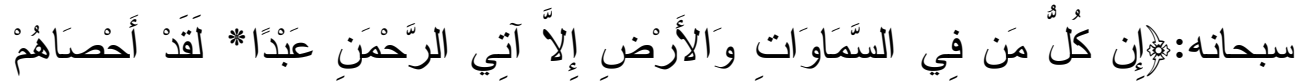

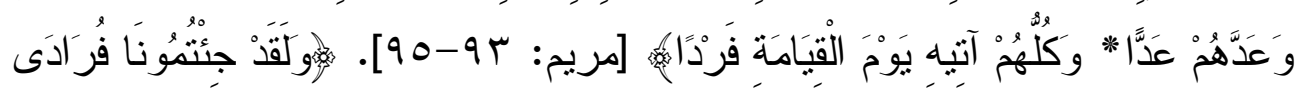

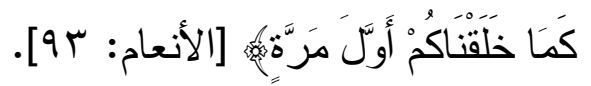


القيامة الكبرى (مشاهد ووقائع، دروس وعبر)

قال تعالى: بهاو لا تكسب كل نفس إلا عليها و لا تزر وازرة وزر أخرى ثم إلى

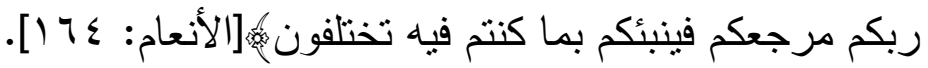

وهذا هو العدل الذي لا عدل فوقه، فالمهتدي يقطف ثمار هدايته، و الضال

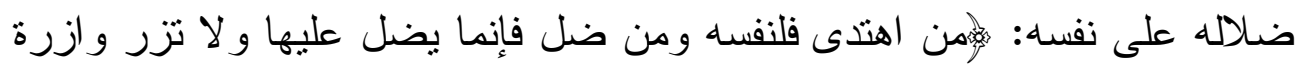
وزر أخرى وما كنا معذبين حتى نبعث رسو لامئ. [الإسر اء: 7 1]

و هذه القاعدة العظيمة التي اتفقت الرسالات السماوية على تقريرها، قال تعالى:

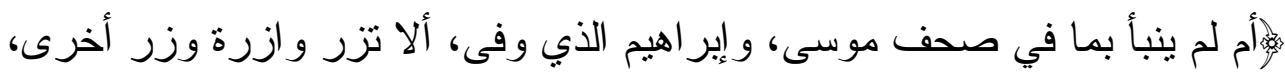

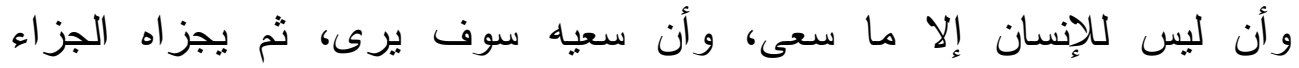

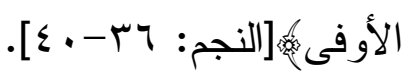

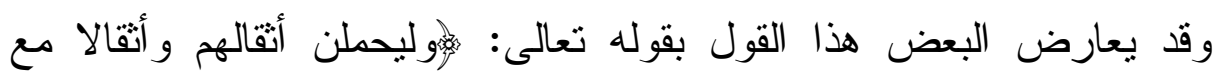

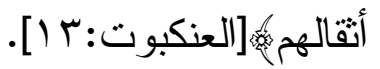

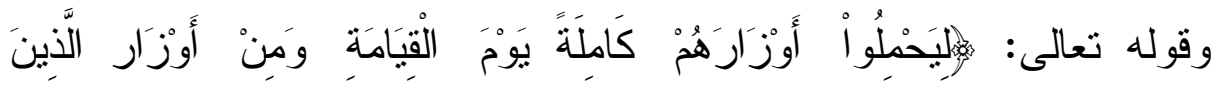

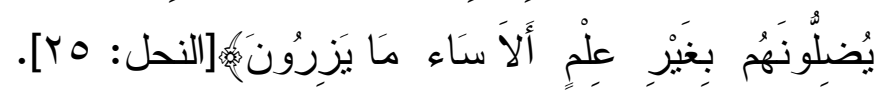

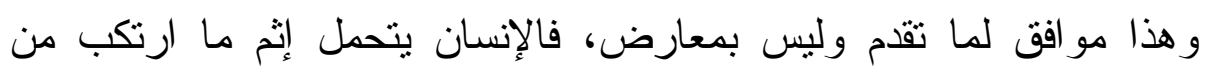

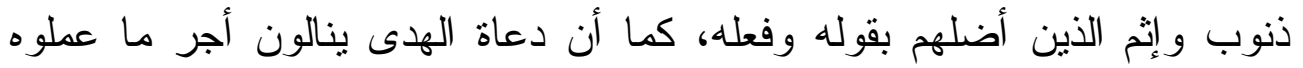
ومنل أجر من اهتدى بهديهم، فإضلال هؤلاء لغير هم هو فعل يعاقبون عليه كذلك. يقول رَسُونُ اللَّهَ

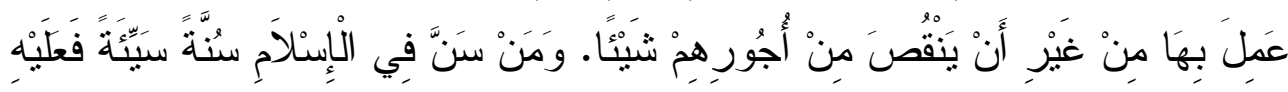

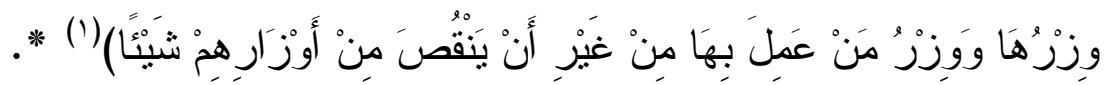


القيامة الكبرى (مشاهد ووقائع، دروس وعبر)

القاعدة الثالثة: إطلاع العبادعلى ما قدموه من أعمال:

من إعذار اله لخلقه، وعدله في عباده أن يطلعهم على ما قدموه من صالح

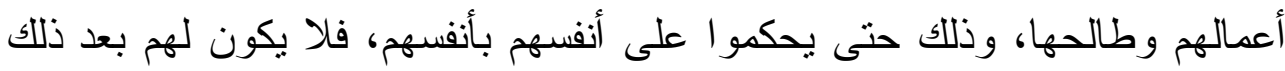

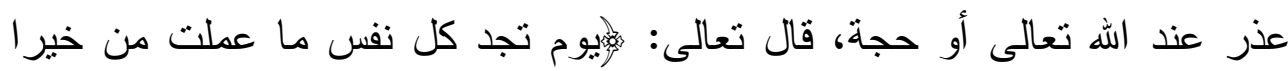

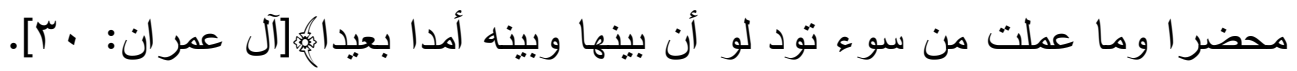

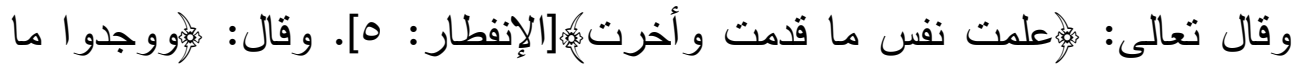

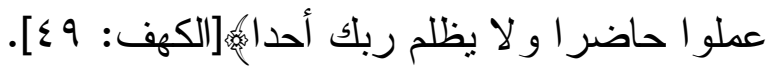
و إطلاع العباد على ما قدموه يكون بإعطائهم صحائف أعمالهم. وقر اءتهم لها

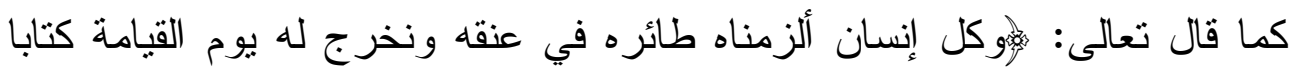

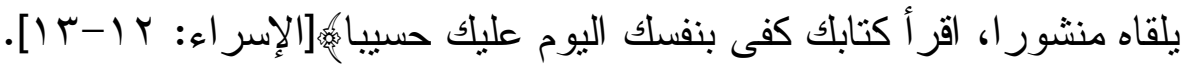
وهو كتاب شامل لجميع الأعمال كبيرها وصغيرها بهووضع الكتاب فترى

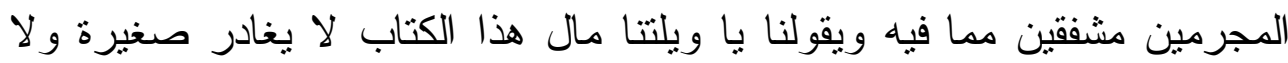

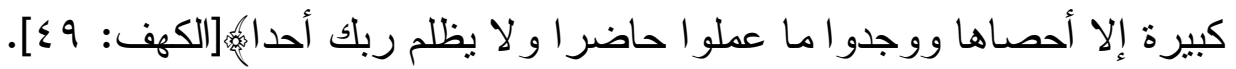

\section{القاعدة الر ابعة: مضاعفة الحسنات دون السيئات:}

ومن رحمة المولى سبحانه بعباده وتفضله عليهم أنه سبحانه يضاعف لهم الحسنات دون السيئات ولزإن تقرضوا الله قرضا حسنا يضاعفه لكم ويغفر

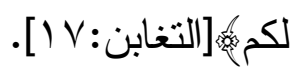

وأقل ما تضاعف به الحسنة عشرة أضعاف بهن جاء بالحسنة فله عشر

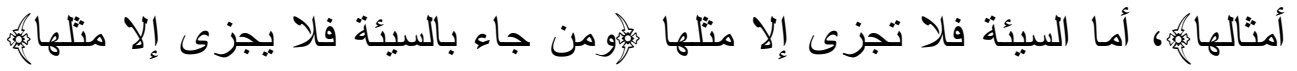

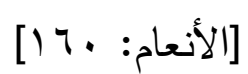

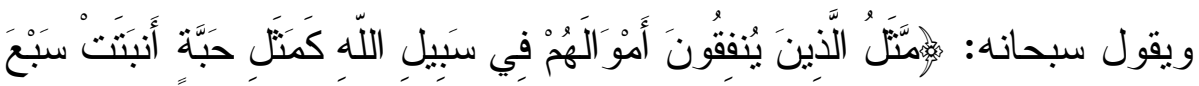


القيامة الكبرى (مشاهد ووقائع، دروس وعبر)

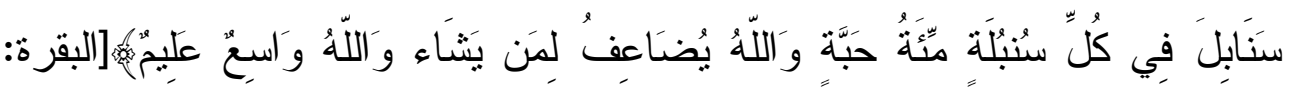

و هذا مقتضى عدله تبارك وتعالى، بل إن هذا من كامل عفوه وفضله ورحمته

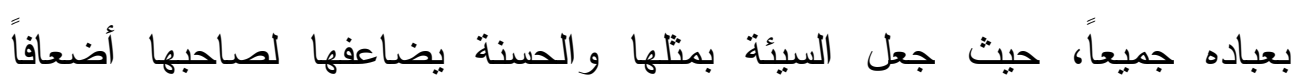

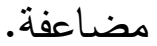

قال عليه الصلاة و السلام فيما برويه عن ربه ثبارك وتعالى أَنَّهُ قَالَ:(الْحَنَنْة

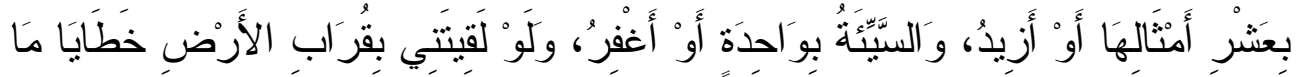

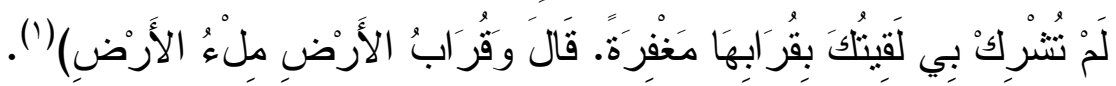
وقد تصل مضاعفة الحسنة إلى سبعمائة ضعف، وأكثر من ذلك كما قال

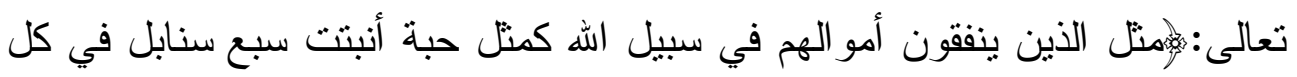

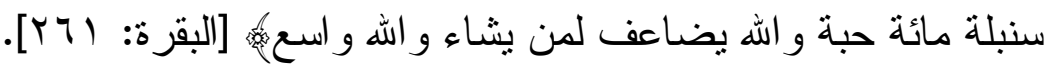

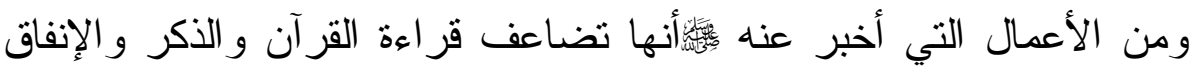
و الجهاد و الحج و الصوم و الصبر و غير ها كثير مما لم نحصر هـ هنا. وتتجلى رحمة الله وفضله على عباده أن المؤمن الذي يهم بفعل الحسنة ثم لا يفعلها تكتب له حسنة تامة، و الذي يهم بفعل السيئة ثم لا يفعلها مخافة لله تكتب له له

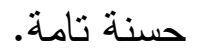

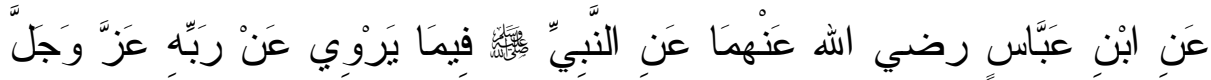

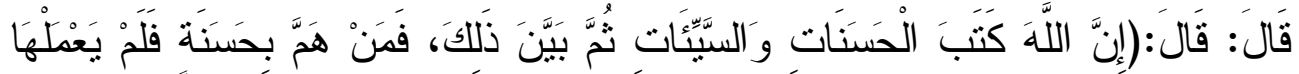

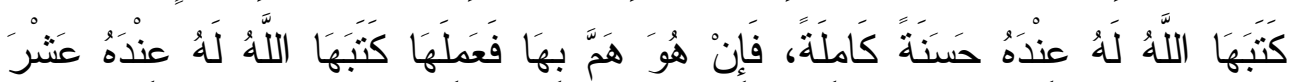

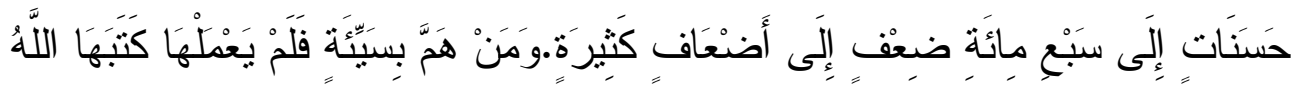

$$
\begin{aligned}
& \text { ( () السند للإمام أحمد بن حنبل. مسند الأنصار . حديث رقم r.ror. ror. } \\
& -|Y|-
\end{aligned}
$$


القيامة الكبرى (مشاهد ووقائع، دروس وعبر)

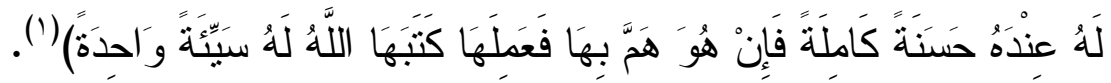
و من واسع رحته وفضله نبارك وتعالى أن يبدل السيئات حسنات كما قال

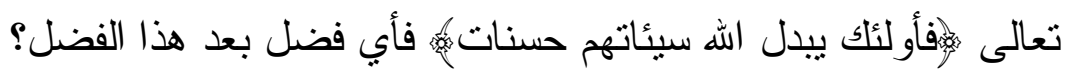
القاعدة الخامسة: إقامة الشهود على الكفرة و المنافقين:

إن الحق سبحانه لا تخفي عليه خافية في الأرض ولا في السماء، يعلم خائنة الأعين وما تخفي الصدور ، و علمه بظاهر العباد كعلمه بسر هم سو اء بسو اء، حيث

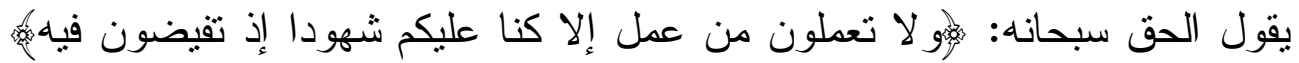

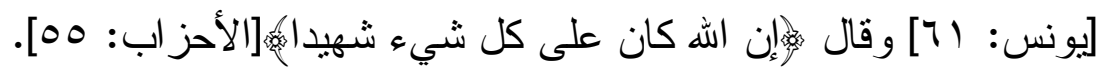
ومع ذلك فإن الحق سبحانه لا يحاسب عباده بمقتضي علمه بهم وكثفه لأحو الهم. بل إنه سبحانه بحب الإعذار إلى خلقه فيبعث من مخلوقاته شهداء على المكذبين الجاحدين حتى لا يكون لهم عذر كما قال تعالى "فكيف إذا جئنا من كل

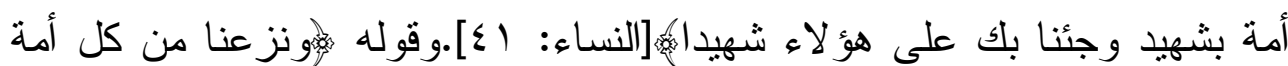
شهيدا فقلنا هاتو ا برهانكم

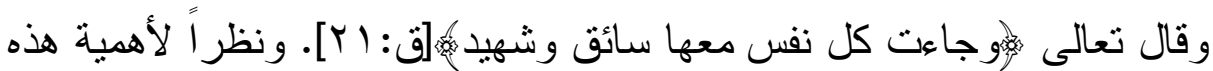
الشهادة سنخصص لها مبحثًا مستقلاً بعد ذلك. هذا عن القواعد التي سيحاسب على أساسها العباد يوم القيامة(؟)، أما عن الأعمال التي سيحاسبون عليها ويُسألون عنها فهي على النحو التالي:

\section{الأعمال التي يحاسب عليها العباد في يوم القيامة}

إن من سنة الله في خلقه أنهم قد خلقهم في حياتهم الدنيا ليبلوهم أيهم أحسن

(1) (البخاري. كتاب الرقاق. حديث رقم • 1 ـ ج.

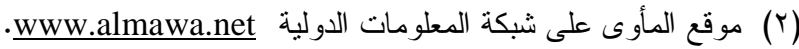


القيامة الكبرى (مشاهد ووقائع، دروس وعبر)

عملا، وجعل الدنيا دارًا للعمل والآخرة دارًا للحساب والجزاء، حيث يُسأل العبد فيها عن كل ما قدمت يداه، ويحاسب عن كل ما بدر منه في حياته الانيا، فيُسأل عن عقيدته و إيمانه وكفره عن عمره وشبابه عن صحته و عافيته عن نفسه وولده، ولا يبقى في حياته أمر إلا وقد سُّل عنه، ولا يمر من عمره لحظة إلا وكان الحساب عليها عسير كل ذلك يُسأل عنه العبد في هذا اليوم وتفصيل ذلك على النحو التالي:

\section{أولا: الكفر والشرك:}

و أعظم ما يُسأل عنه العباد هو كفر هم وشركهم، فيسألهم تعالى عن الثركاء

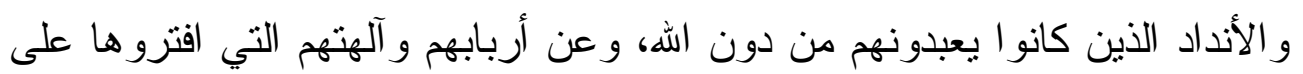
الله، كما قال تعالى:

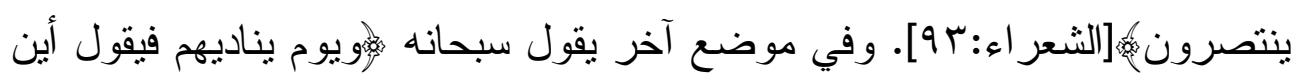

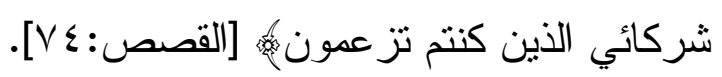
ويُسألون عن عبادتهم لغير الله من تقديم القرابين للآلهة التي كانوا يعبدونها

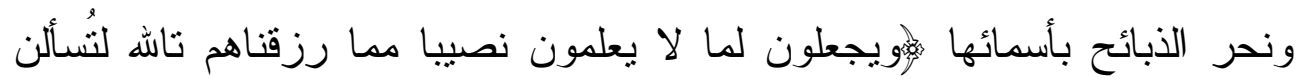
عما كنتم تفتزون

ويسألون عن تكذيبهم للرسل، وكفرهم بالأنبياء والكتب مهوبوم يناديهم فيقول ماذا أجبتم المرسلين، فعميت عليهم الأنباء يومئذ فهم لا يتساءلون

\section{ثانيا: ما عمله في دنياه:}

كذلك يسأل العبد في يوم القيامة عن جميع أعماله التي عملها في الحياة الدنيا، عن حسناته وسيئاته، و عن غدر اته وفجر اته، وعن آثامه ومعاصيه، عن كل ما بدر 
القيامة الكبرى (مشاهد ووقائع، دروس وعبر)

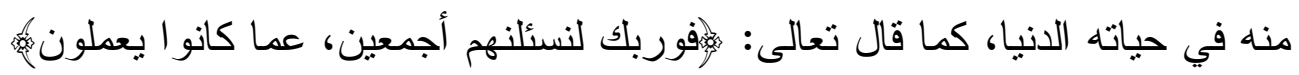

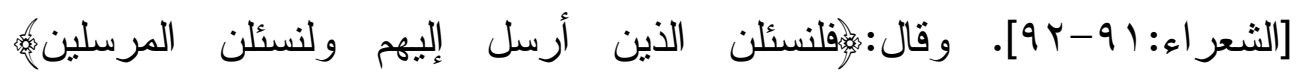
[الأعر اف:1]].

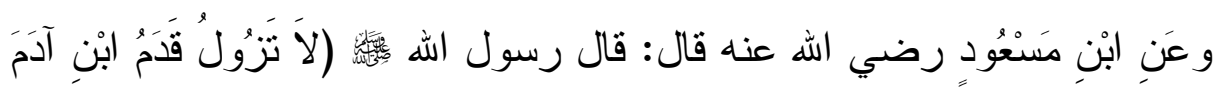

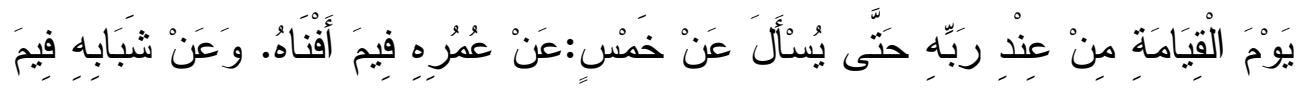

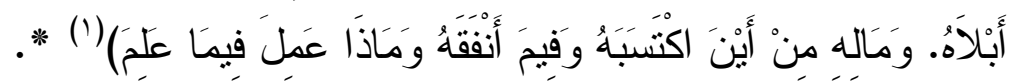

و المتأمل في الحديث يعلم السر في دعوة الرسول صلى الله عليه المسلم إلى ملى

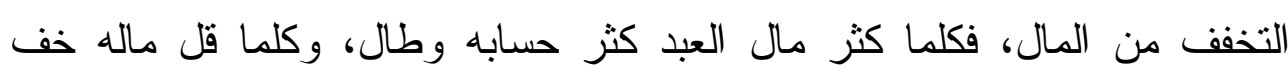
حسابه وأسر ع به إلى الجنة، وقد أخبر عليه الصلاة و السلام أن فقر اء المهاجرين

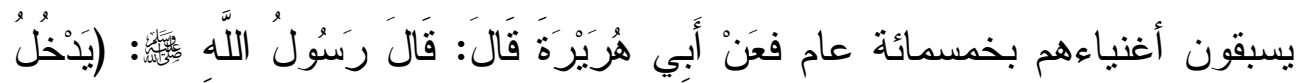

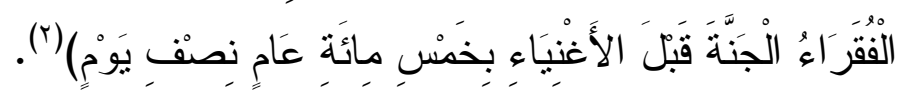

\section{ثالثا: النعيم الذي يتمتع به:}

يسأل الله عباده في يوم القيامة عن النعيم الذي خولهم إياه في الدنبا كما قال

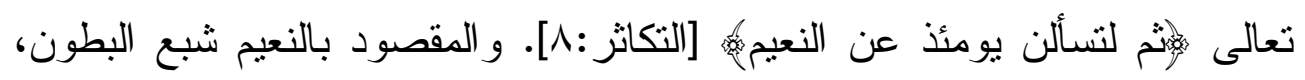
وبارد الماء، وظلال المساكن، و اعتدال الخلق، ولذة النوم، وقال سعيد بن جبير:

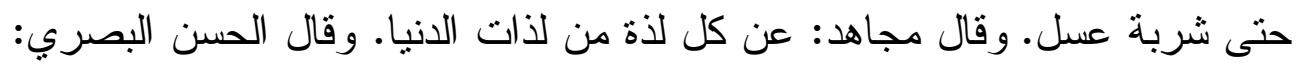

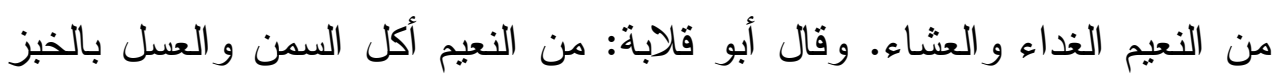

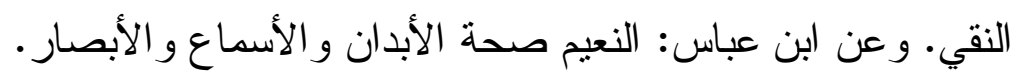
و هذه الذي فسروها به من باب التتوع في التفسير، و إلا فإن أصناف النعيم 


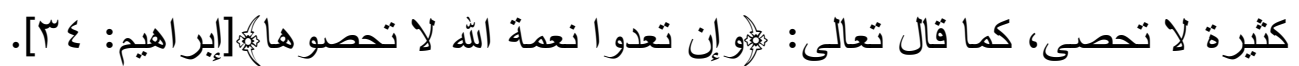

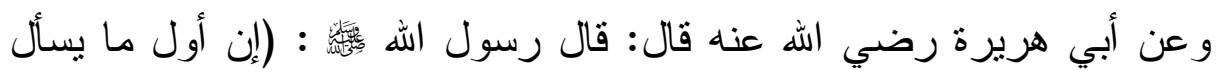

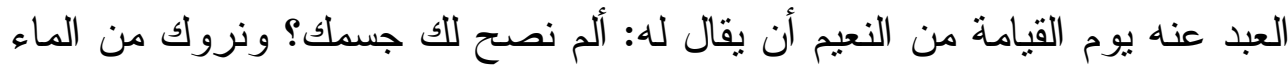

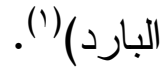

وبعض الناس لا يستشعر النعم العظيمة التي وهبه اله إياها، فلا يدرك النعمة

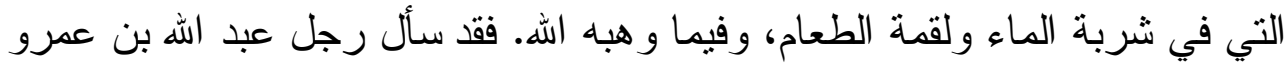
بن العاص فقال: ألسنا من فقراء المهاجرين؟ فقال عبد الله: ألك امر أة تأوي إليها؟

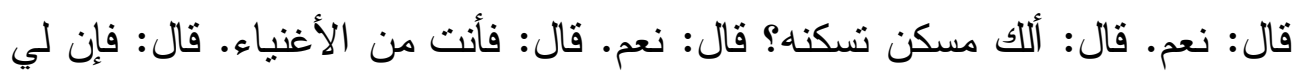

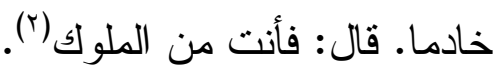

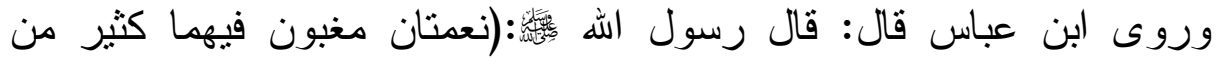

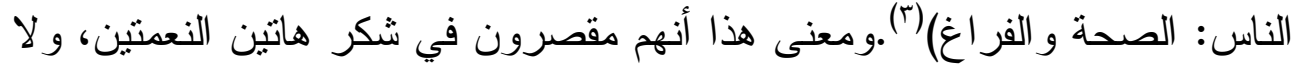

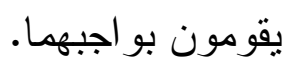

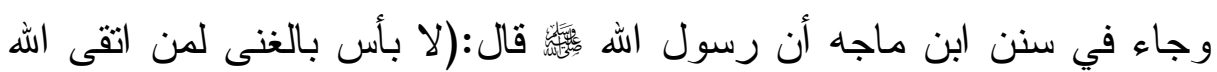

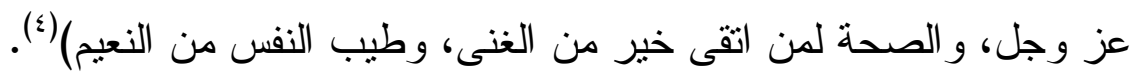

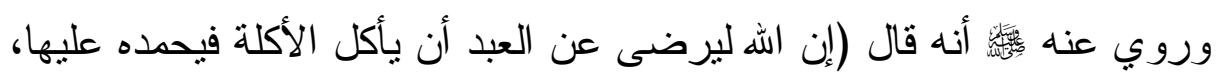
أو يشرب الثربة فيحمده عليها)(ه). رابعا: العهود والمواثيق: يسأل الله عباده عما عاهدوه عليه إهولقد كانوا عاهدوا الله من قبل لا يولون

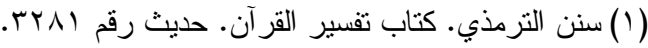

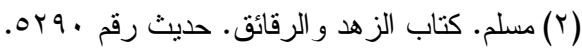

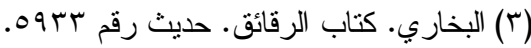

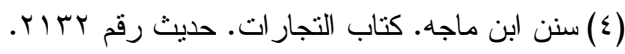

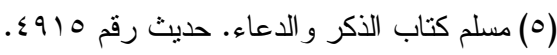


القيامة الكبرى (مشاهد ووقائع، دروس وعبر)

الأدبار وكان عهز الله مسؤو لامة. [الأحز اب: 10].

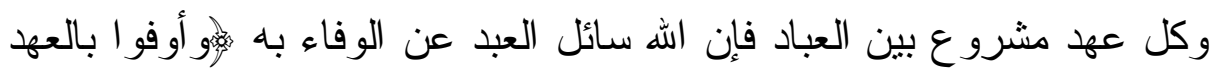

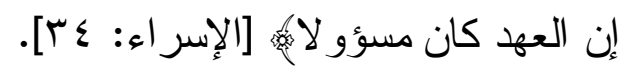

خامسا: السمع والبصر والفؤاد

يسأل اله العباد عن جميع ما يقولونه، ولذلك حذرهم من القول بلا علم الهو لا لا

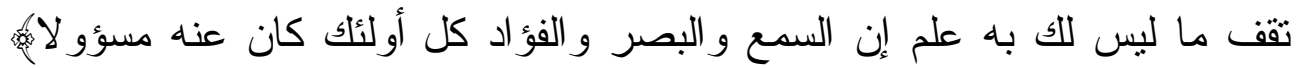

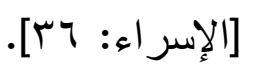

قال قتادة: لا تقل رأيت ولم تر ، وسمعت ولم تسمع، وعلمت ولم تعلم فإن الله سائللك عن ذلك كله. حجة الله البالغة

إن الأمر لله -سبحانه- و الملك التام له ويتجلي هذا على أنم أحواله و أكمل أوضاعه في يوم القيامة فهو المحيي والمميت، وهو القاهر فوق عباده وهو الحكيم

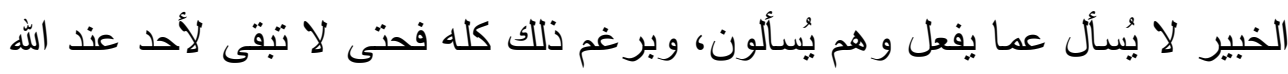

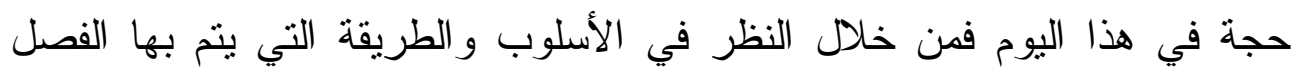

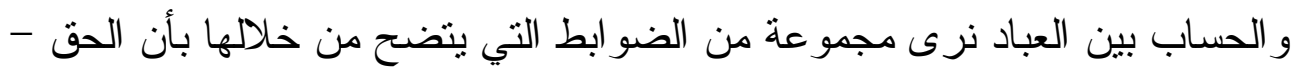

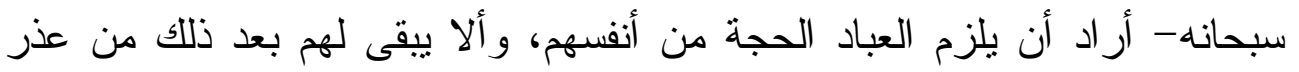
وليهلك من هلك عن بينة ويحيي من حيي عن بينة وأن الله لسميع عليم. هذه الضو ابط تتمنل في أمور كثبرة منها: 1- شهود الإثبات. r - الصحائف والسجلات. ب- الوزن والميزان. 1-شهود الإثبات:

ونقصد بشهود الإثبات مجموعة الثهاء الذين يقيمون الحجة على العباد في 
هذا الموقف، حينما تعرض قضيتهم بين بدي أحكم الحاكمين سبحانه-وتعالى. إذا كان الناس في حياتهم الدنيا في حاجة إلى شهود إثبات حتى يمكنهم إثبات

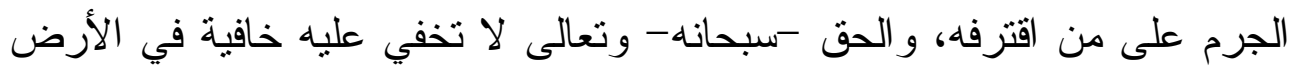

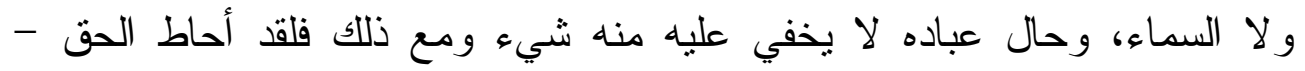

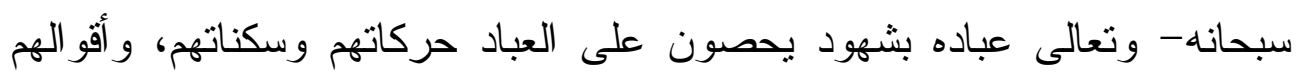

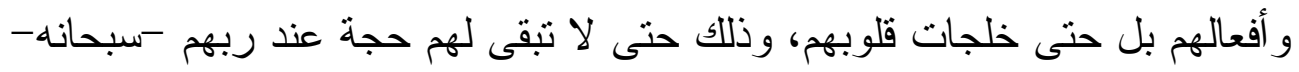
ويمكننا أن نبين أحو الهم فيما يأتي:

\section{أولا: شهادة الحق سبحانه وتعالى:}

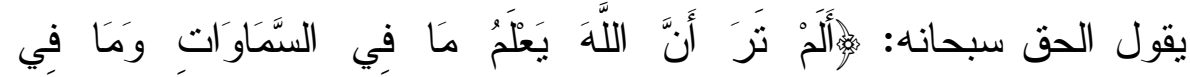

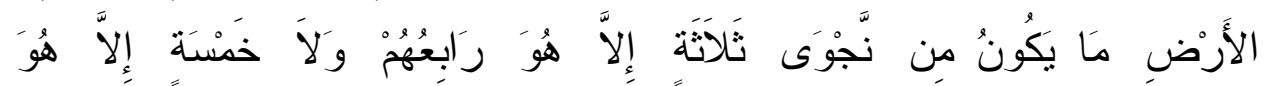

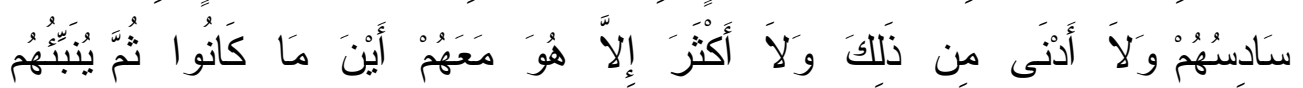

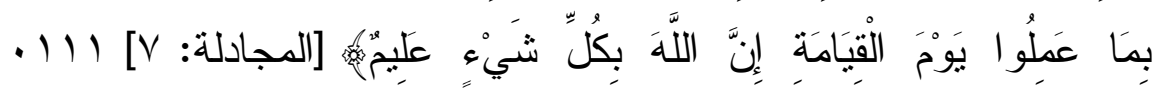

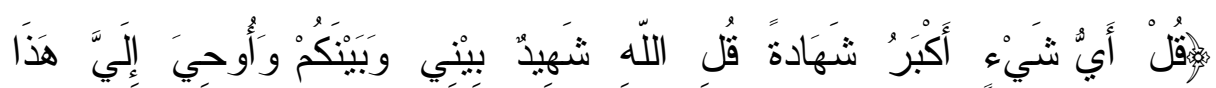

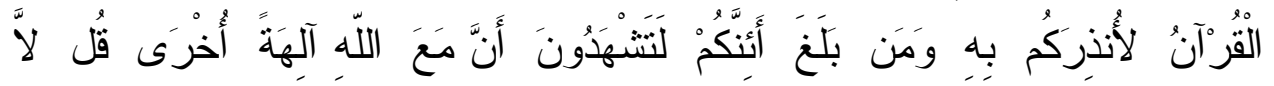

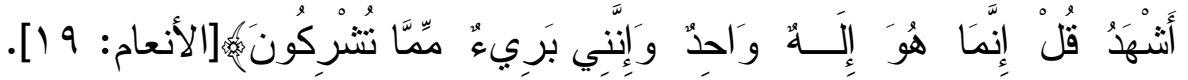

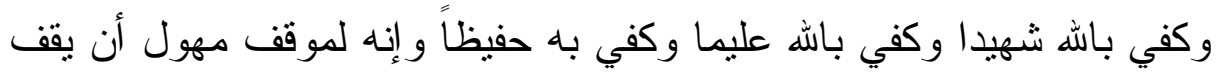
العبد بين يدي ربه سبحانه وتعالى وينبئه ربه بكل صغيرة وكبيرة في حياته فالأمر كما قال الحق سبحانه: (أحصاه الله ونسوه).

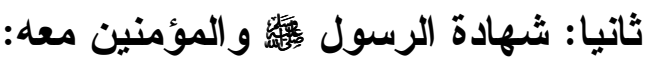

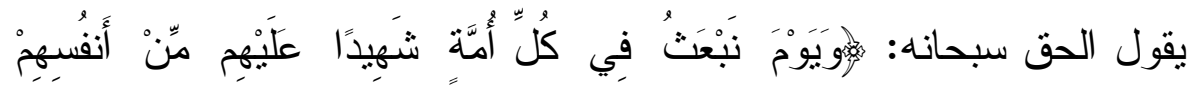

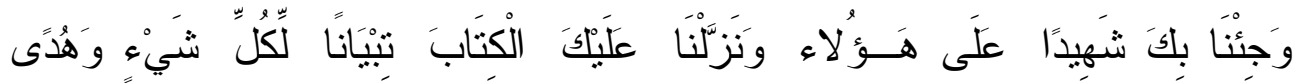




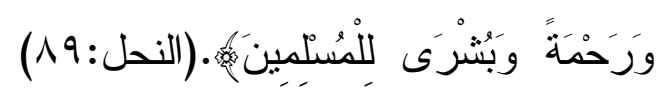

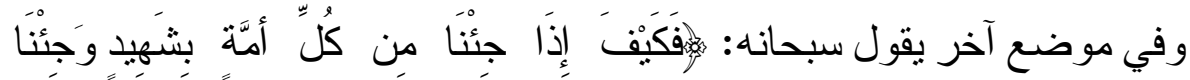

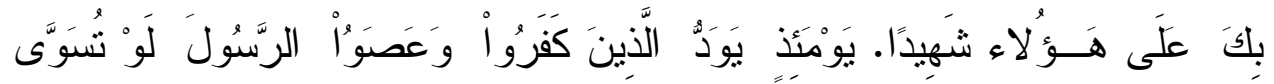

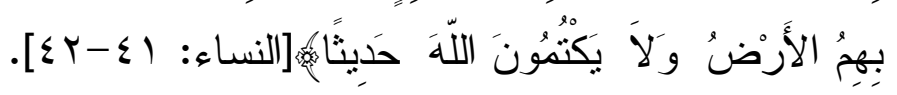

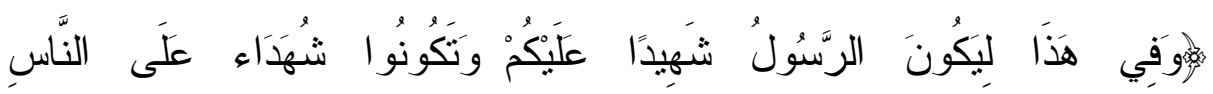

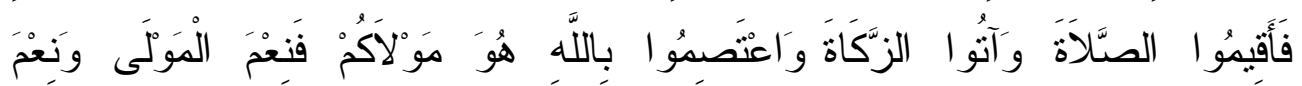

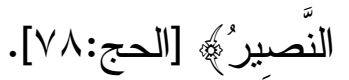

و هذه من أصعب المواقف على العباد أن يأتي رسول اله الأمة في هذا اليوم وهو رسول الله

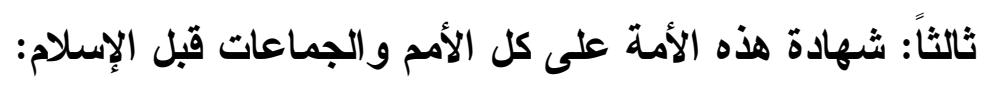

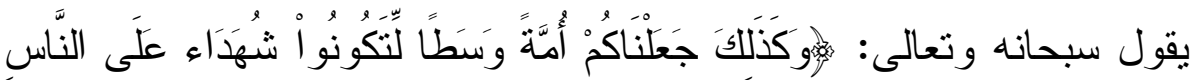

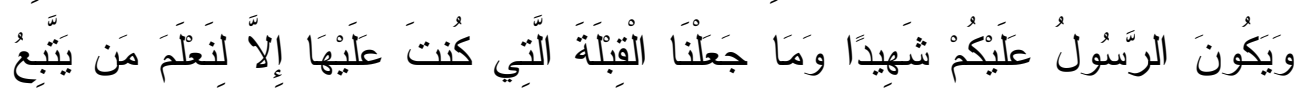

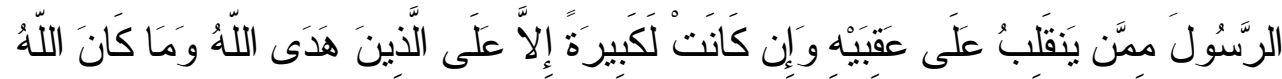

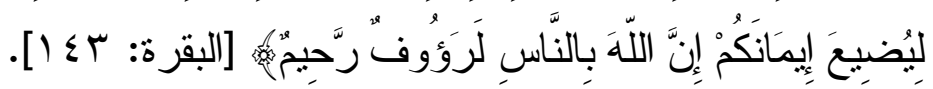

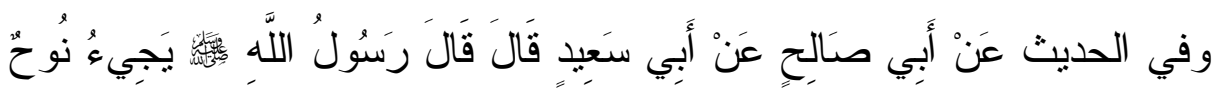

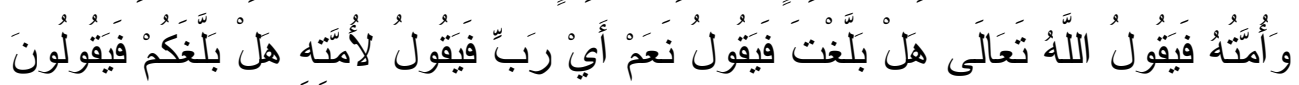

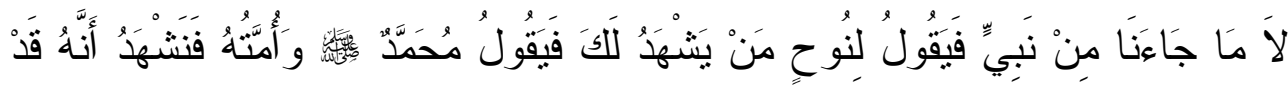

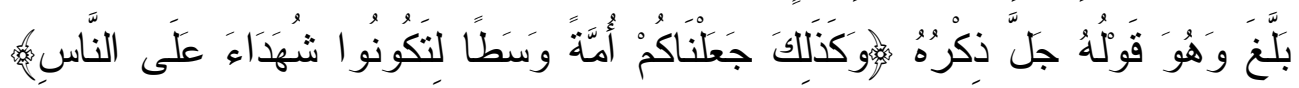

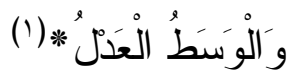


القيامة الكبرى (مشاهد ووقائع، دروس وعبر)

رابعاً: شهادة الكون بما فيه:

ومع ذلك فإن الثهادة لا تقتصر على ذلك، فإن الحق سبحانه قد جعل من العالم المحيط بالعباد جعل من الكون المحيط بعباده أجهزة تسجيل نسجل على العباد

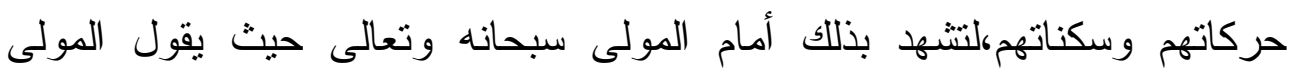

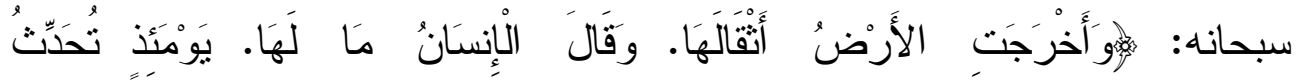

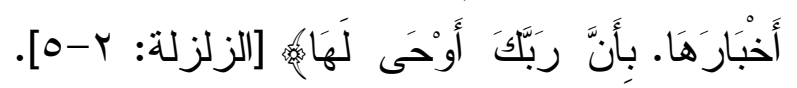

خامساً: شهادة الملانكة الكرام البررة:

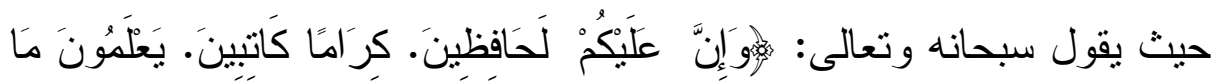

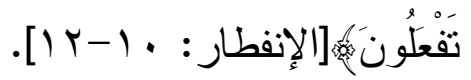

هؤ لاء جميعاً أقامهم الحق -سبحانه- حجة على عباده يأنون عليهم شهوداً يوم

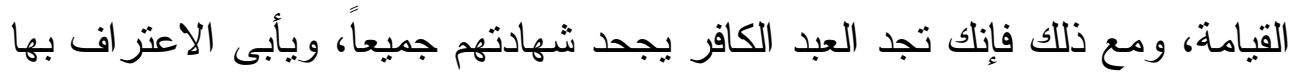

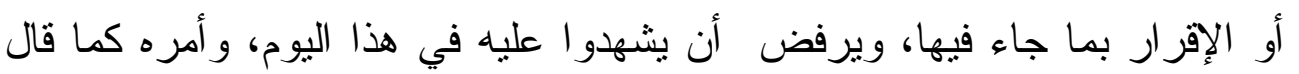

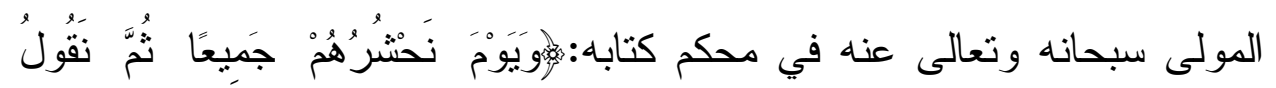

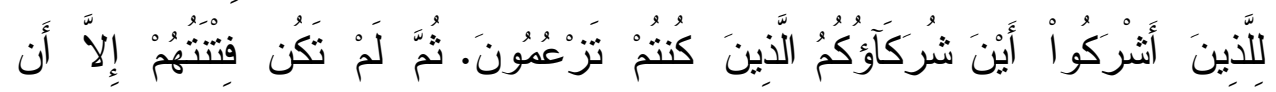

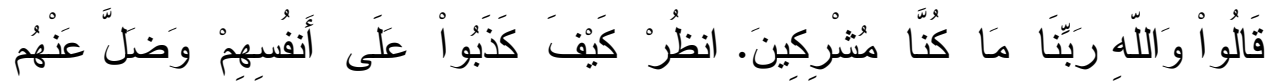

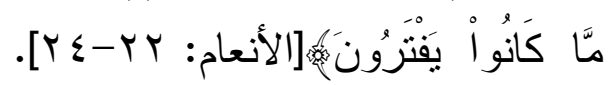

فحينما يفعل العبد هذا ويجد شهادة هؤ لاء جميعاً بهذه الصورة الفجة التي بتجر أ

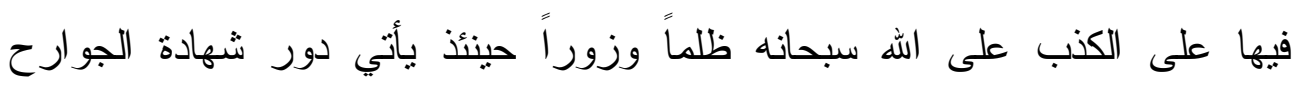
و الأعضاء وهو شاهد إثباته الذي يلزمه الحجة ويبهته فلا يستطيع جو اباً أو رداً: سادساً: شهادة الجوارح و الحو اس:

إن الحق سبحانه قد خلق الإنسان و أنعم عليه بنعم لا تحصى وخير ات لا تعد 
القيامة الكبرى (مشاهد ووقائع، دروس وعبر)

حيث يقول سبحانه:

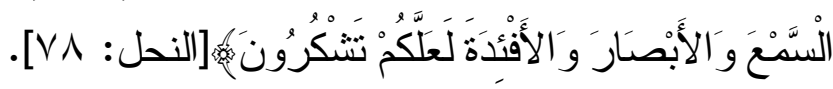

و هذه الجوارح هي منة من عند الله ووديعته عند عباده، ويؤكد لهم المولى

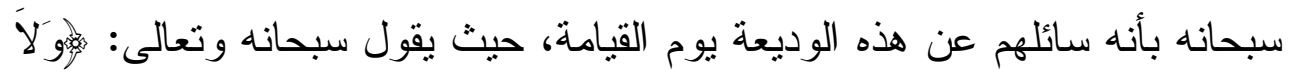

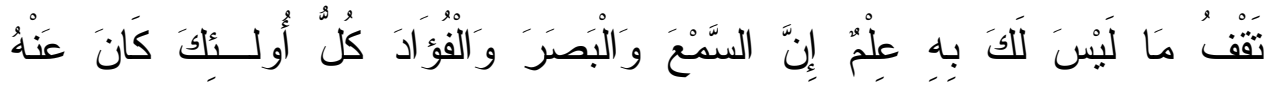

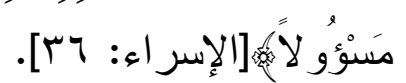

ولقد كان لهذه الجوارح النصيب الأكبر في ارتكاب المرء للمعصية،

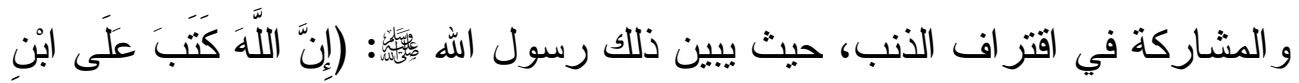

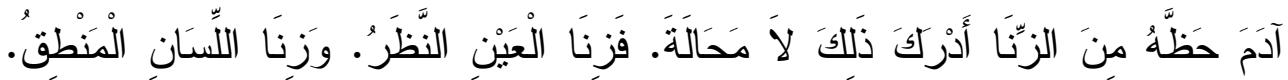

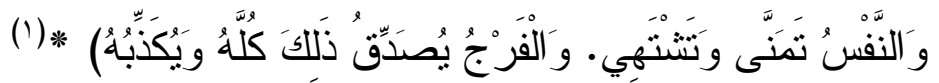

فكما كان لهذه الجوارح حظها من الاستمتاع بالمعصية و التلذذ بها، فهي تأخذ نصيبها كذلك من الألم و العذاب، و أولى خطوات هذا العذاب أن تبدأ هي بالثهادة

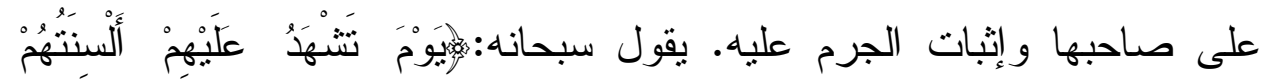

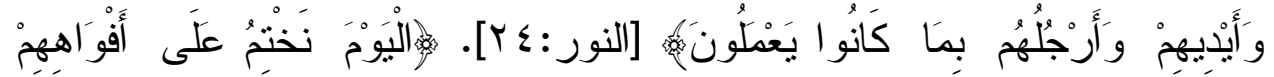

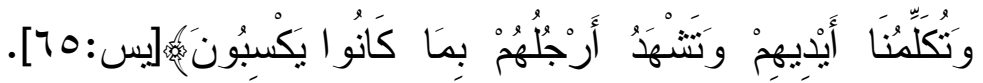

هَ

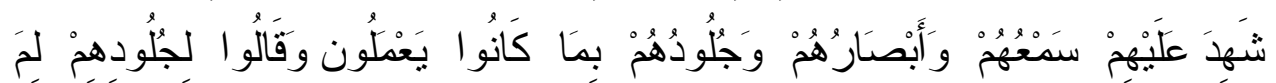

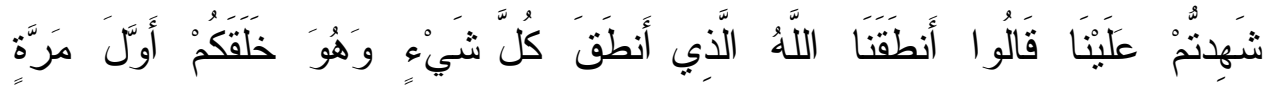

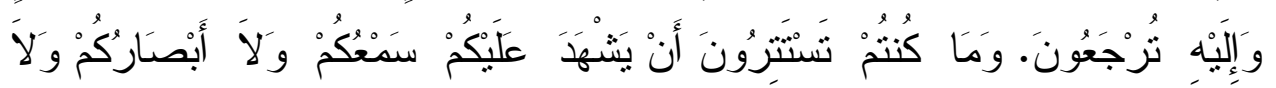

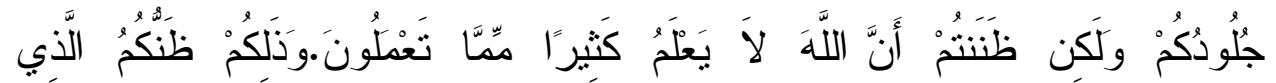




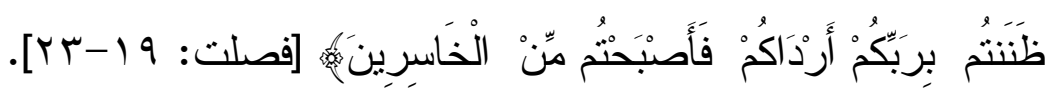

وما جاء مجملا عن هذه الثهادة في كتاب الله تعالى جاء بيانها وتفصيل حالها

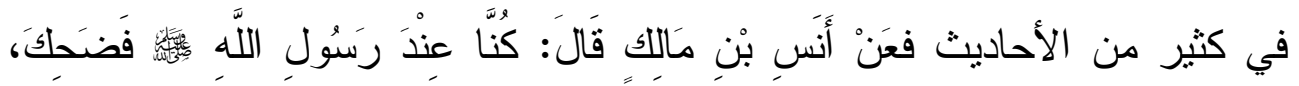

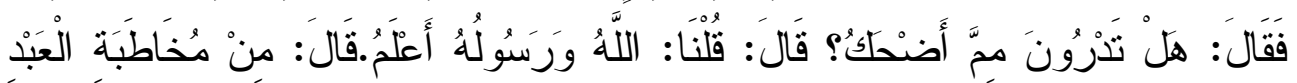

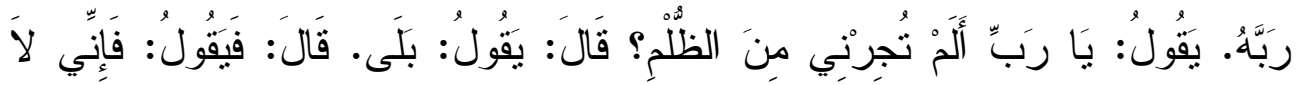

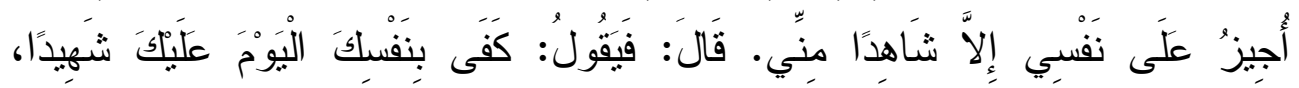

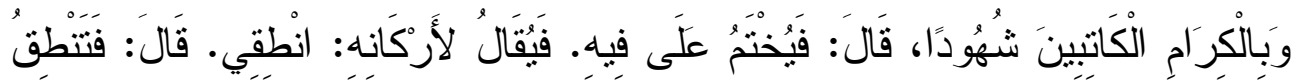

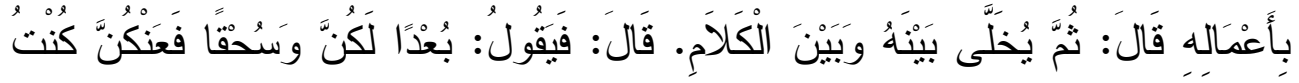
(أُناضَ

حقا إنه لموقف عصيب أن يكون شهود الإثبات على المرء أعضاؤه وجو ارحه التي اقترفت الذنب وشاركت في الجرم.

لقد أقام الحق سبحانه- الحجة على عباده في هذا اليوم فشهدت عليهم الأرض و الملائكة الأبرار و المرسلون الأخيار، ومع ذلك ومع شهادة هؤلاء فإن العبد يكابر أمام ربه ويجحد شهادتهم جميعاً، وينكر ذنوبه، و لا يقر بخطاياه، حيث

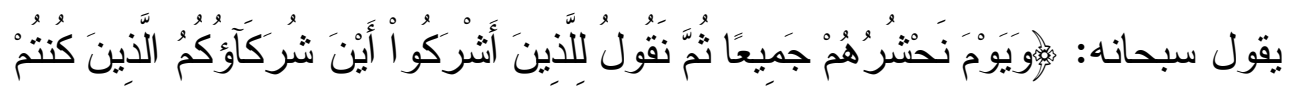

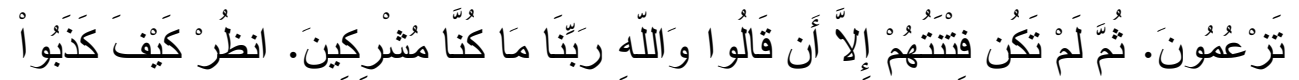

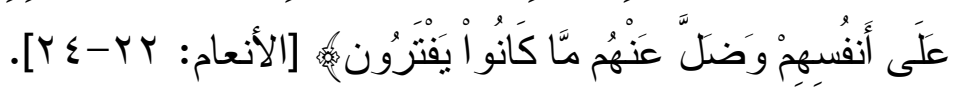
فحينما يصل الأمر إلى ذلك تأتي شهادة الجوارح و الأعضاء لتكون هي الحجة الدامغة التي لا يستطيع العبد بعدها رداً أو يجد جواباً، فحديث الجوارح وشهادة

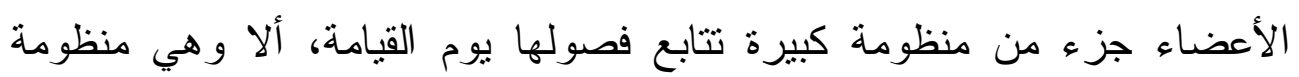


الحساب بين يدي الجبار سبحانه وتعالى يوم القيامة، ويتم الأمر على هذا النحو

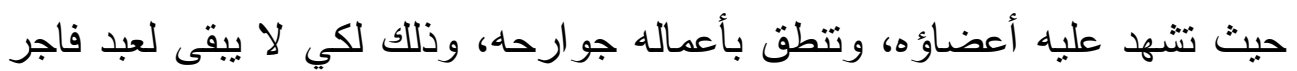

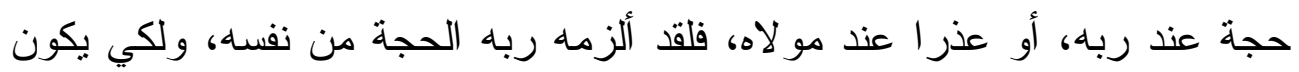

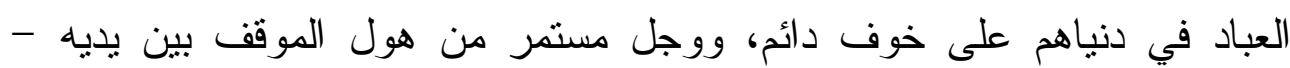
سبحانه- وتعالى.

\section{Y}

مع أن الحق - سبحانه - لا تخفى عليه خافية في الأرض ولا في السماء،

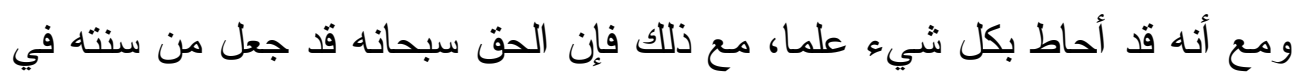

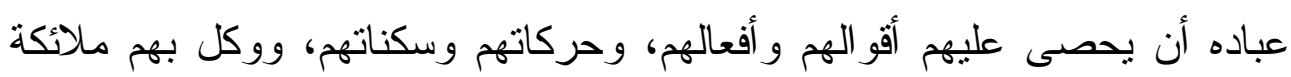

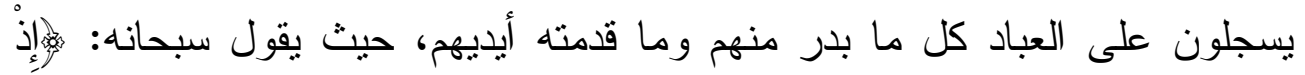

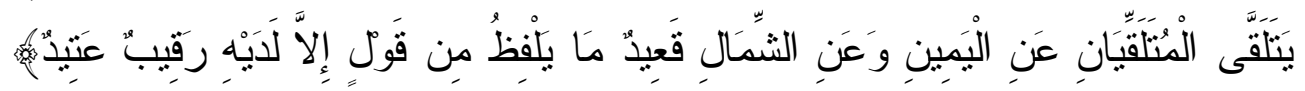

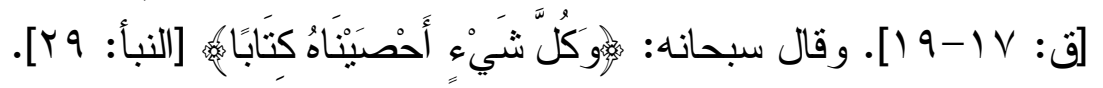
هذا الكتاب قد دُون فيه كل شيء، وسجل فيه مثتقال الذر و الخردل وما ترك

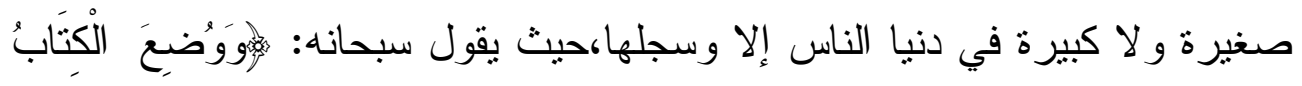

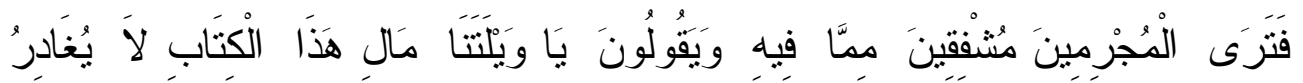

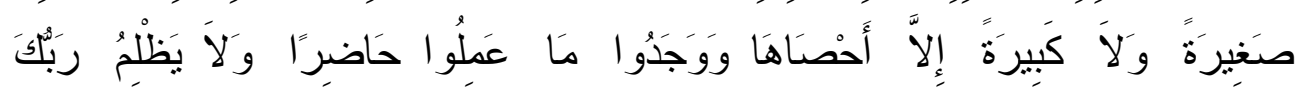

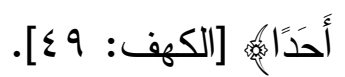

فإذا ما جاء يوم القيامة فإن هذه الصحف تتطاير حتى تلزم أعنق أصحابها في

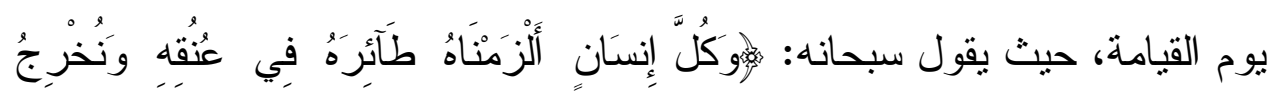

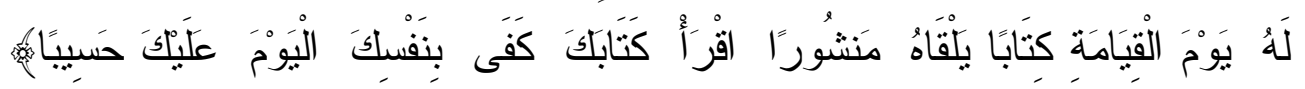

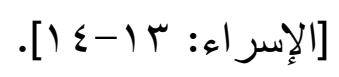


القيامة الكبرى (مشاهد ووقائع، دروس وعبر)

هذا ولقد بينت آيات القرآن بأن الناس عند تتاولهم لصحائف أعمالهم مذاهب

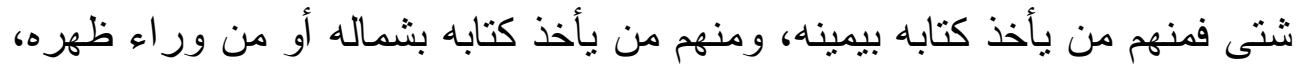

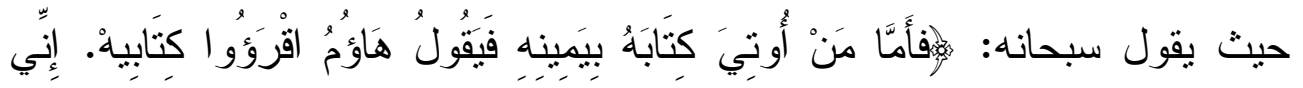

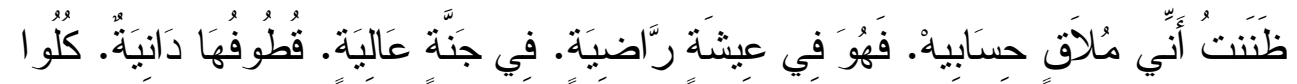

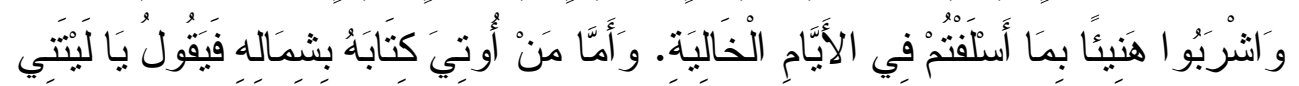

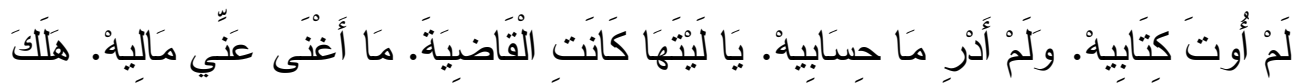

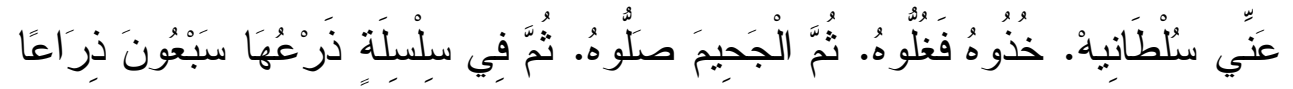

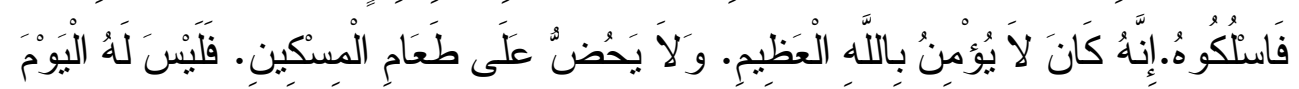

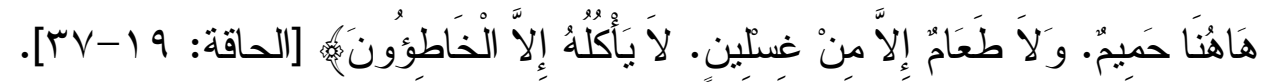

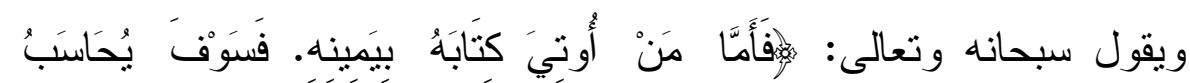

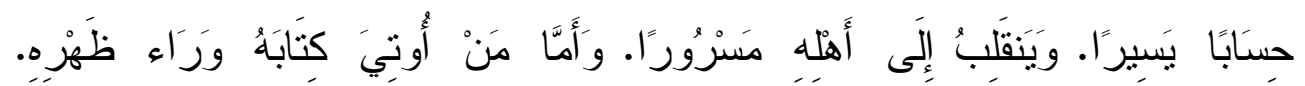

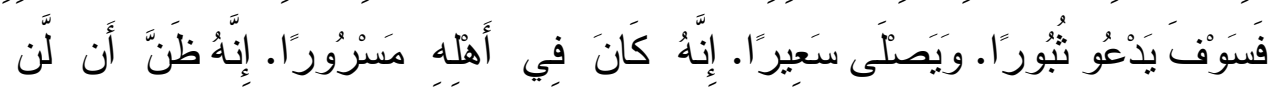

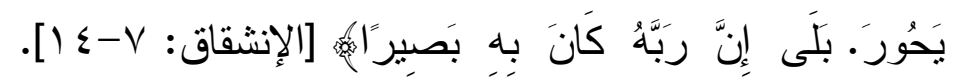

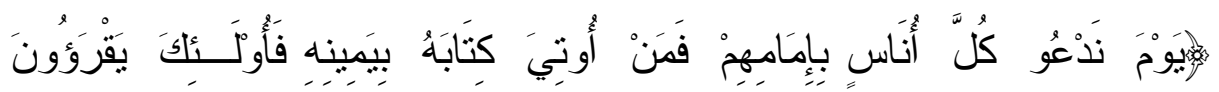

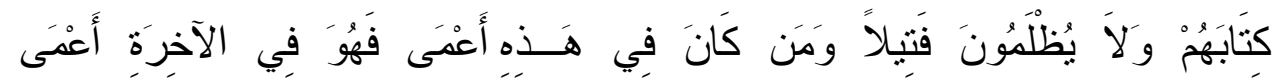

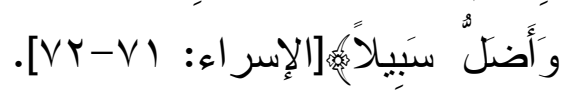

مشهُ من مشاهد العرض و الحساب

من رحمة الله بعباده أن الحق سبحانه- قد كثف لهم في كتابه وعلى لسان نبيه الكثير من مشاهد يوم القيامة ومنها مو اقف العرض و الحساب كيف يكون حال المؤمن عند الحساب وبأي طريقة يحاسب الكافر و المنافق و الفاسق، وسنذكر منها

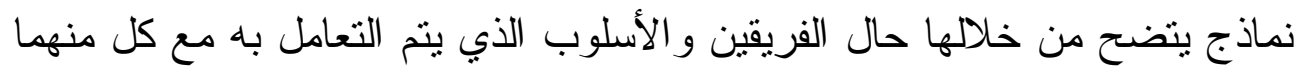




\section{- أن فرحة وسرور أوحسرة وندامة:}

هذا هو حال الفريقين عندما تتطاير الصحف وتتشر دوو ايين الأعمال وهذا ما

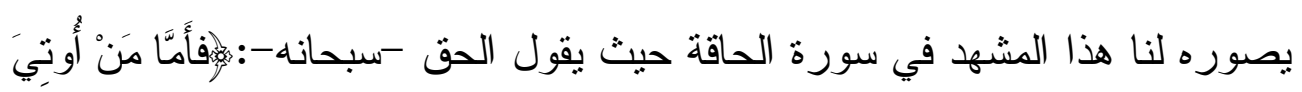

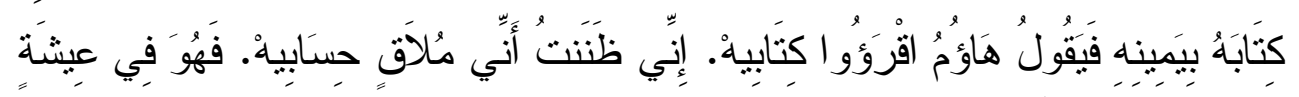

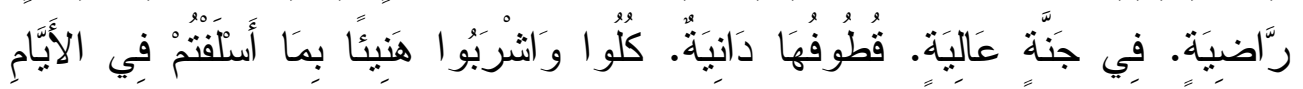

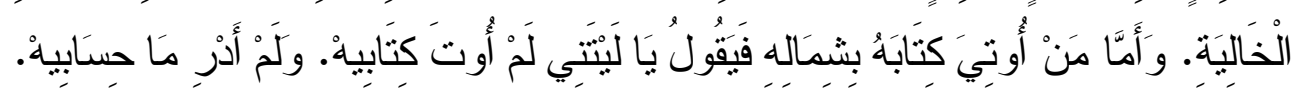

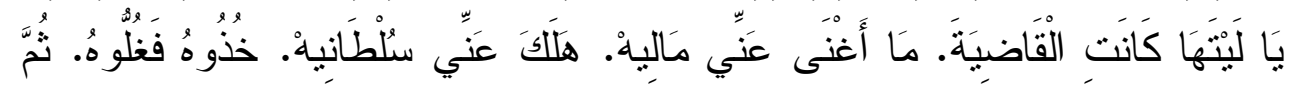

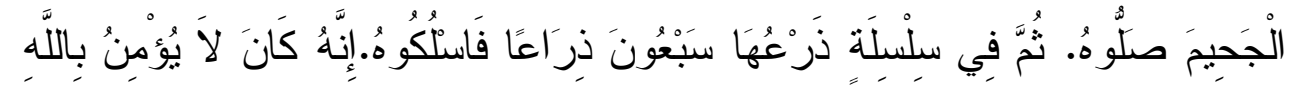

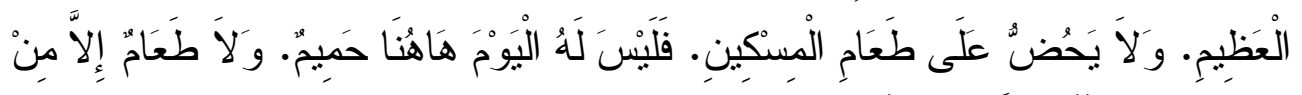

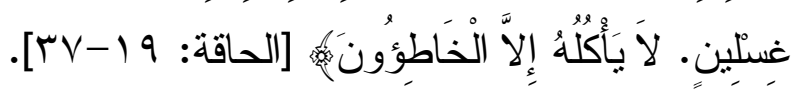

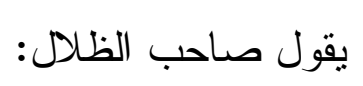

وأخذ الكتاب باليمين وبالثمال ومن وراء الظهر قد يكون حقيقة مادية، وقد

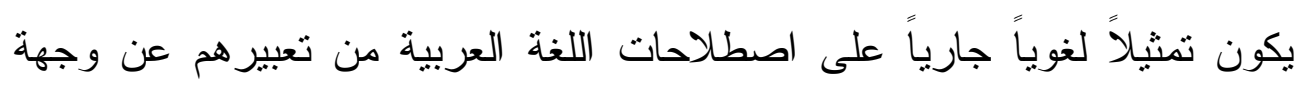
الخير باليمين ووجهة الثر بالثمال أو من وراء الظهر .. وسواء كان هذا أو ذالك

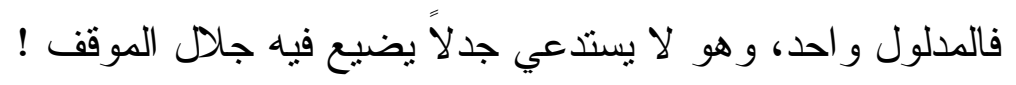

و المشهر المعروض هو مشهذ الناجي في ذلك اليوم العصيب، وهو ينطلق في جاي فرحة غامرة، بين الجموع الحاثدة، تملأ الفرحة جوانحه، وتنغلبه على لئل لسانه،

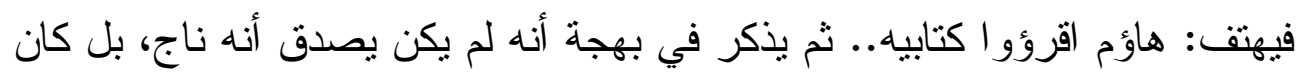
يتوقع أن ينافش الحساب.. " ل

ثم بعلن على رؤوس الأشهاد ما أعد لهذا الناجي من النعيم، الذي تبدو فيه هنا 
ألوان من النعيم الحسي، تتاسب حال المخاطبين إذ ذالك، وهم حديثو عهذ بجاهلية،

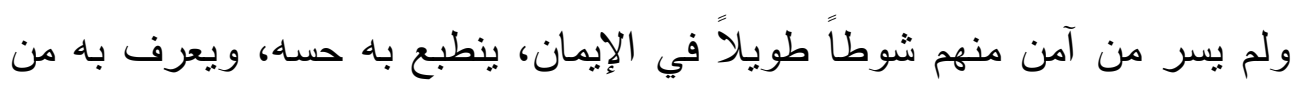

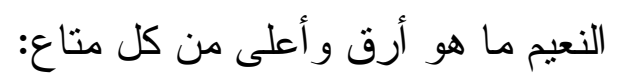

(فهو في عيشة راضية. في جنة عالية. قطوفها دانية. كلو ا و اشربوا هنيئا بما

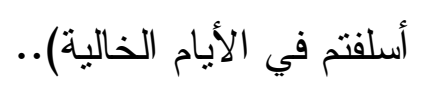

و هذا اللون من النعيم، مع هذا اللون من التكريم في الالتقات إلى أهله

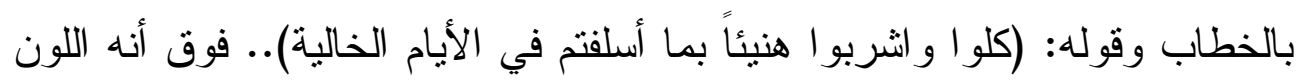

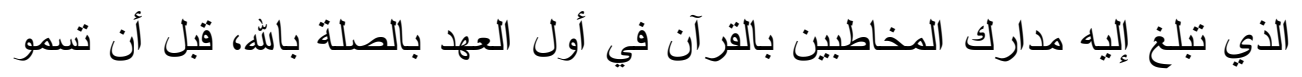
المشاعر فترى في القرب من اله ما هو أعجب من كل متاع.. فوق هذا فإنه يلبي

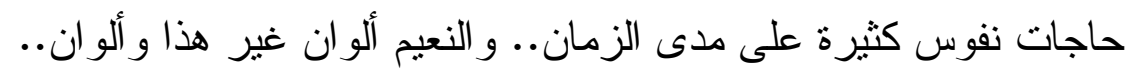

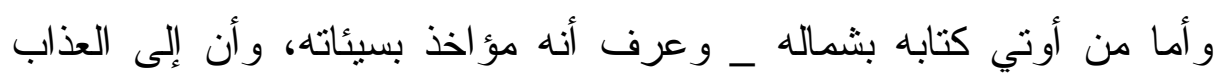

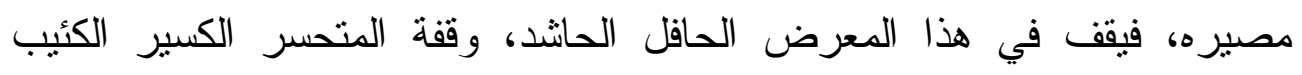

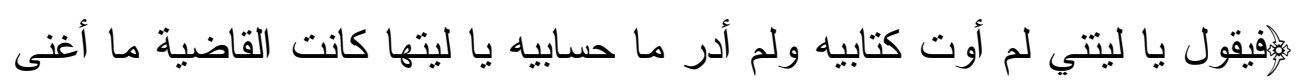

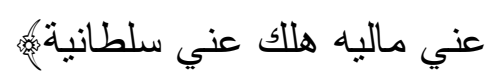

و هي وقفة طويلة، وحسرة مديدة و ونغمة بائسة، ولهجة بائسة. و السياق يطيل

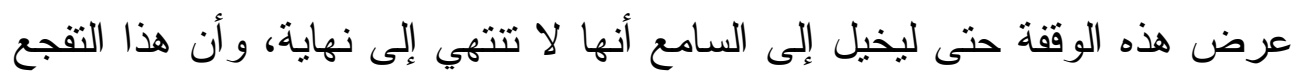

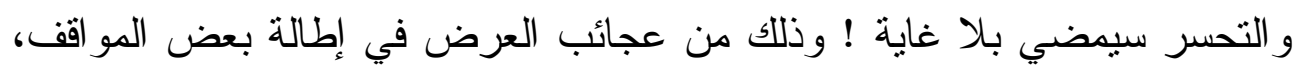

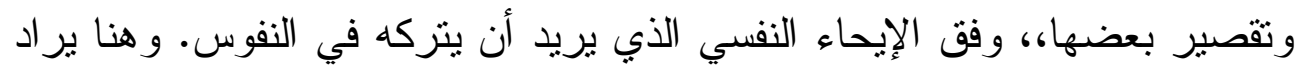

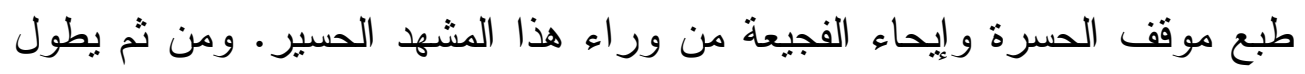

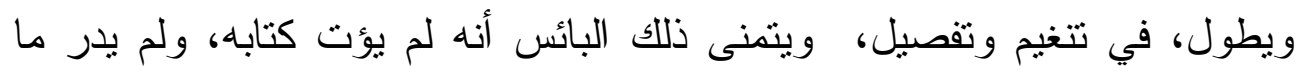
حسابه، كما يتمنى أن لو كانت هذه القارعة هي القاضية، التي تتهي وجوده أصلاً 
القيامة الكبرى (مشاهد ووقائع، دروس وعبر)

فلا يعود بعدها شيئاً. ثُ يتحسر أن لا شيء نافعه مما كان يعتز به أو يجمعه زولما

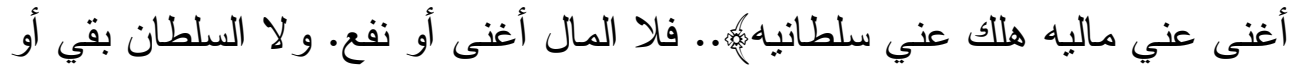
دفع.. و الرنة الحزينة الحسيرة المديدة في طرف الفاصلة الساكنة وفي ياء العلة قبلها بعد المد بالألف، في تحزن وتحسر .. هي جزء من ظعله طله الموقف الموحية بالحسرة والأسى إيحاء بليغاً..

ولا يقطع هذه الرنة الحزينة المديدة إلا الأمر العلوي الجازم، بجلاله وهوله

خوخذوه. فغلوه. ثم الجحيم صلوه. ثم في سلسلة ذرعها سبعون ذراعاً

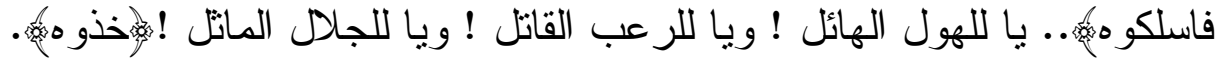
كلمة تصدر من العلي الأعلى. فيتحرك الوجود كله على هذا المسكين الصغير

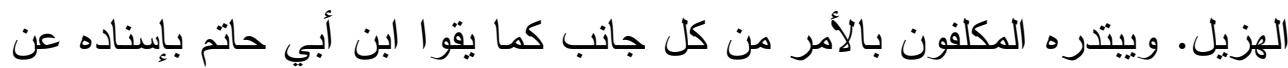
المنهال بن عمرو: (إذا قال اله تعالى خذوه ابتدره سبعون ألف ملك. إن الملك منهم

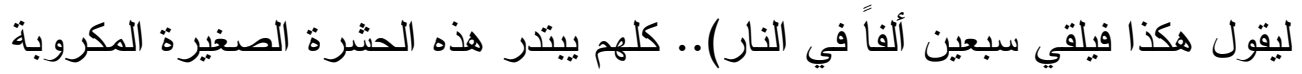

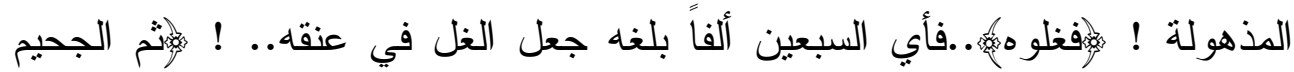

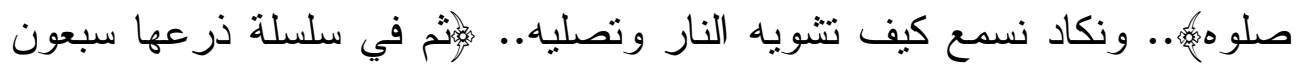
ذر اعاً فاسلكو هومئ...

وذر اع واحدة من سلاسل النار تكفيه ولكن إيحاء التطويل والتهويل ينضح من

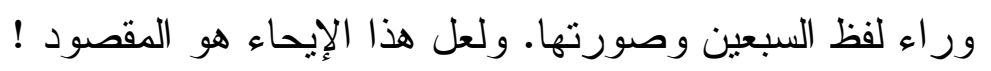

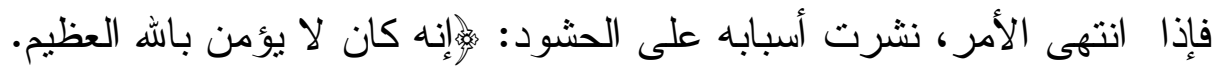

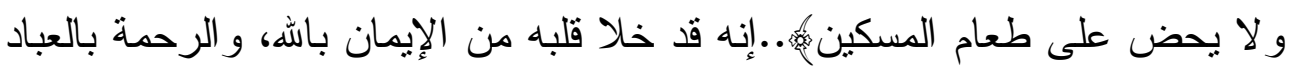
فلم يعد هذا القلب يصلح إلا لهذه النار وذللك العذاب. 
القيامة الكبرى (مشاهد ووقائع، دروس وعبر)

خلا قلبه من الإيمان باله فهو موات، وهو خرب، وهو بور،، وهو خلو من

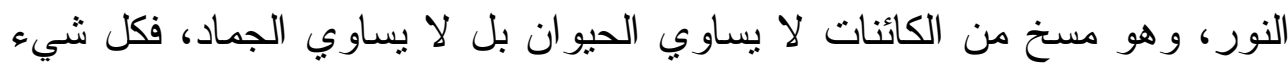

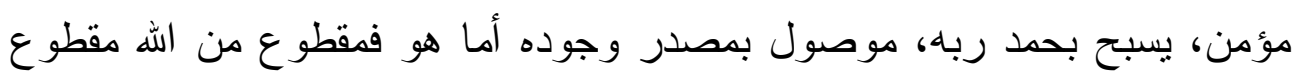
من الوجود المؤمن بالله.

وخلا قلبه من الرحمة بالعباد. و المسكين هو أحوج العباد إلى الرحمة ولكن

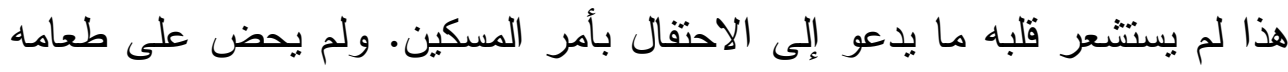

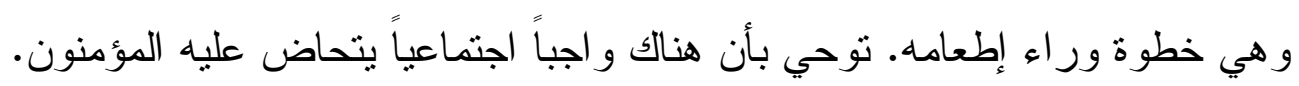
وهو وثثق الصلة بالإيمان. يبينه في النص ويليه في الميزان.

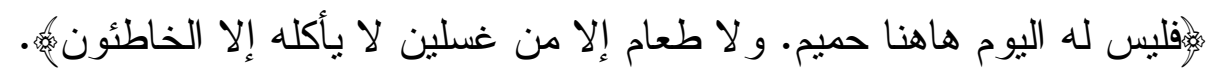
و هي نكملة الإعلان العلوي عن مصير ذللك الثقي هوفلبس له اليوم ها هنا

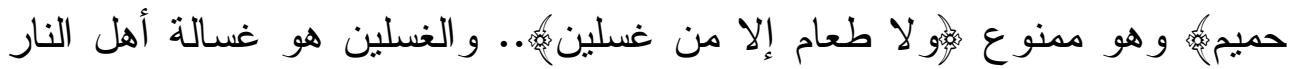

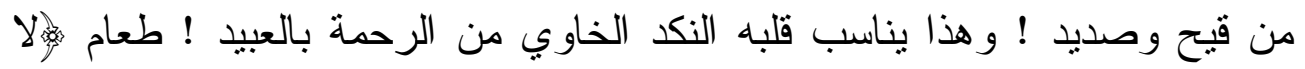

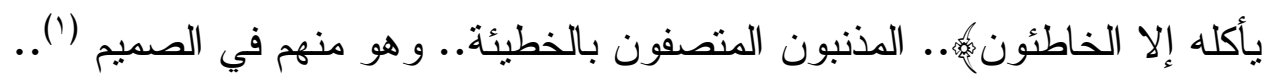

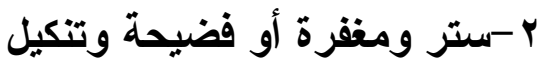

إذا كان المشهد السابق قد صور لنا الحدث وكأنه ساحة من ساحات القضاء فيها، القاضي و المتهم وصحيفة الدعوى وعرض القضية والحكم الصادر بعد

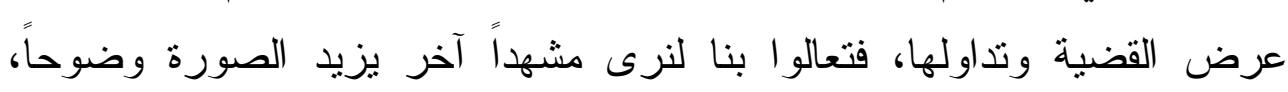
ويكثف لنا عن الكيفية التي يحاسب بها المؤمن باله سبحانه- وكيف يكون حال لتهال

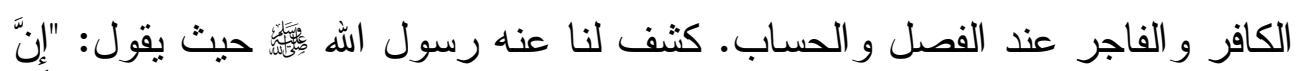

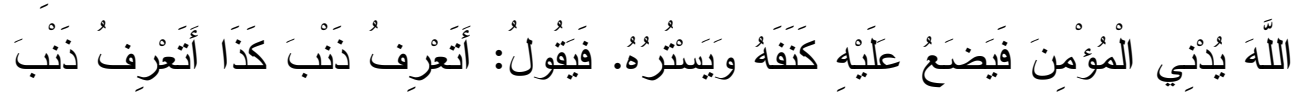




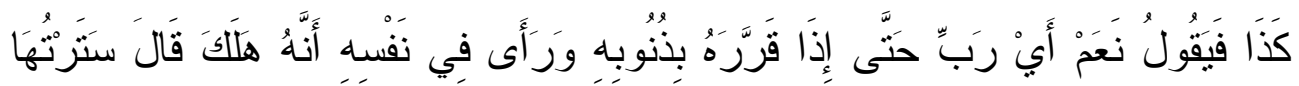

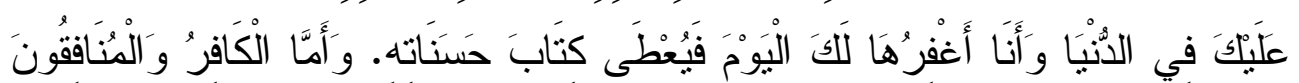
فَيَقول الأَتَهْهَادُ:

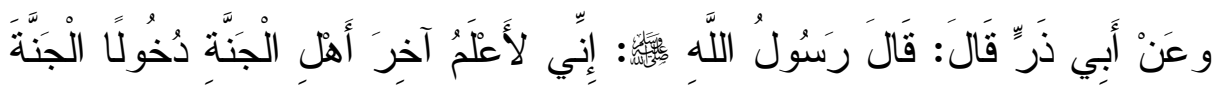

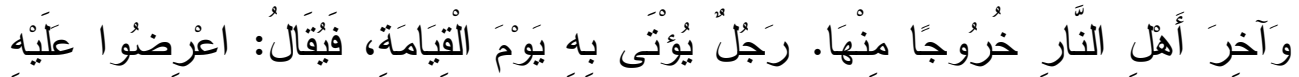

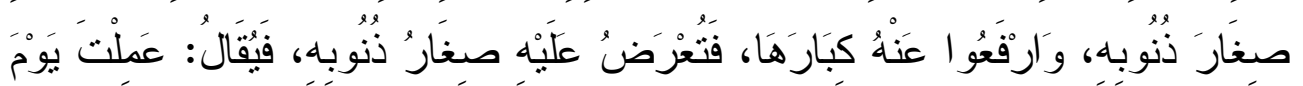

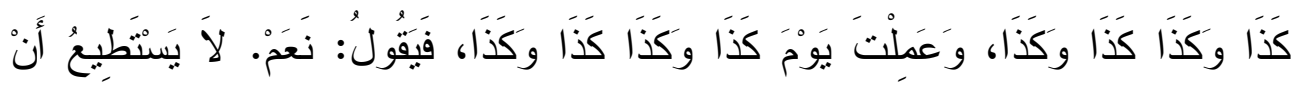

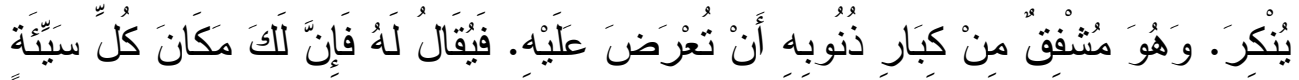

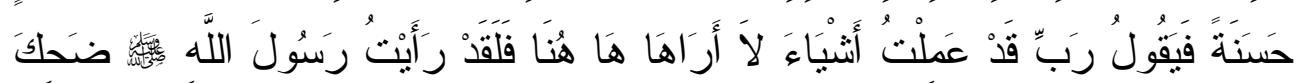

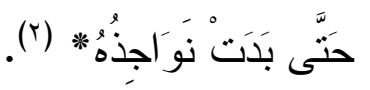

من خلال هذه النصوص يتضح لنا ما يلي:

- مبلغ رحمة الهه -سبحانه- بعباده المؤمنين فحسابهم سراً، ومر اجعة أعمالهم بعيداً عن أهل الموقف جميعاً، فالحق -سبحانه- يضع عليهم كنفه ويسترهم عن أهل الموقف جميعاً، وير اجعهم لا في كل خطاياهم وذنوبهم، و إنما في بعض خطاياهم التي ارتكبوها، وصغار ذنوبهم التي اقترفوها، وهذا من فضل الله عليهم كذلك، أن يستر عليهح كبار ذنوبهم، حتى في العتاب فيما بينه وبينهم.

\section{فضيحة وخزي وندامة}

إذا كانت رحمة الله واسعة وسعت عباده المؤمنين في دنياهم و أخر اهم، فستر

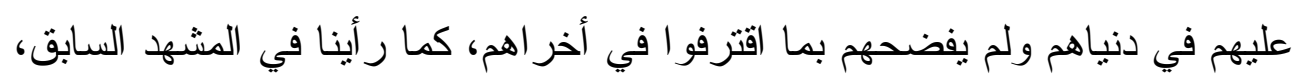

$$
\begin{aligned}
& \text { (1) البخاري. كتاب المظالم و الغصب. حديث رقم الابr. Tr. }
\end{aligned}
$$

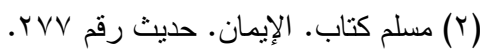


القيامة الكبرى (مشاهد ووقائع، دروس وعبر)

إذا كان هذا حال عباد الله المتقين، عند العرض و الحساب، فإن للكافرين و الفاجرين و الفاسقين و المعربدين في الأرض أسلوباً آخر يتفق وما اقترفو ا من ذنب أو ارتكبو ا من إثم، ولننظر إليهم، في موقف العرض و الحساب كما صورته لنا آيات القرآن: لقد بينت الآيات بأنهم يأتون يحملون أثقالهم و أوز ارهم و أثقال من كانو ا سبباً

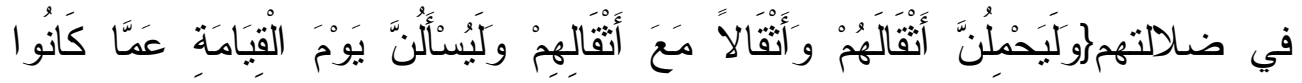
يَفْرَرُونَ (س (I) [العنكبوت

وصحائف أعمالهم التي أخذوها ونظرو ا فيها وأيقنو ا وتأكدو ا بأنها قد أحصت

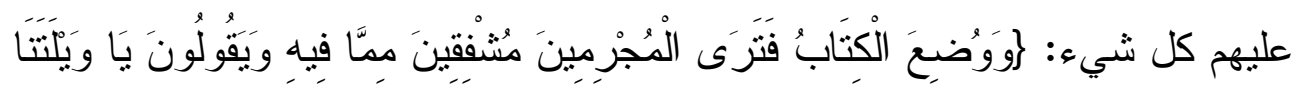

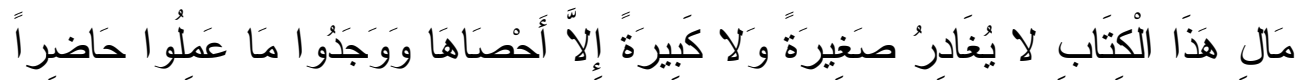

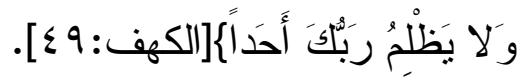

وفي ساحة العرض و الحساب يؤتى بشهود الإثبات فيشيرون إليهم وهم يدلون

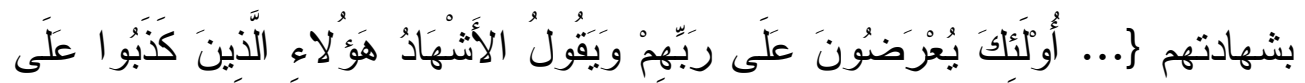

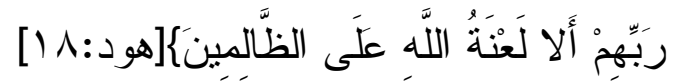

تُر اهم مع ذلك كله هل يعترفون بجرائمهم أو يقرون بخطاياهم و آثامهم كلا!! إنهم في هذا الموقف ومع كل هذا ما تخلوا عن عنادهم وكبرهم، وسوء أخلاقهم، فهم يظنون بأنهم من الممكن أن ينجوا في هذا الموقف بمثل ما كانو ا يصنعون في حياتهم الدنيا، يظنون بأن الأيمان الكاذبة منجية لهم من العذاب، كما كانت منجية

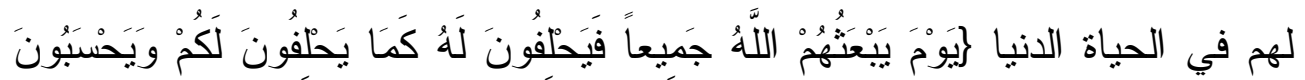

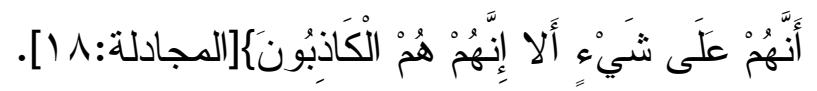
إنهم يلجئون إلى الأيمان المغلظة يقسمون بأغلظ الأيمان و آكدها باله سبحانه

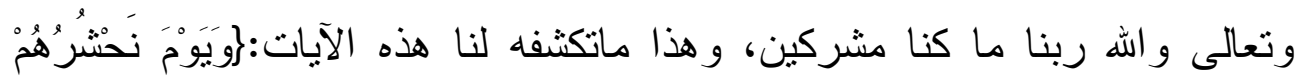




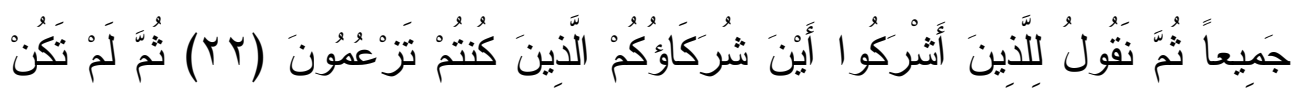

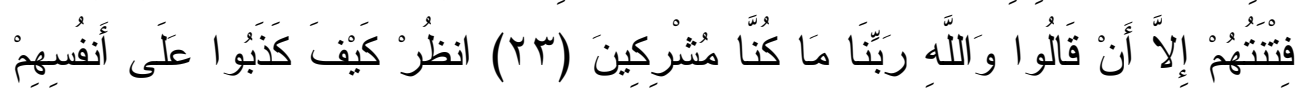

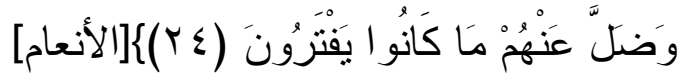

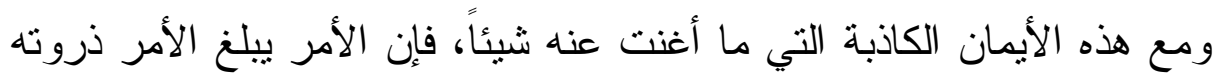

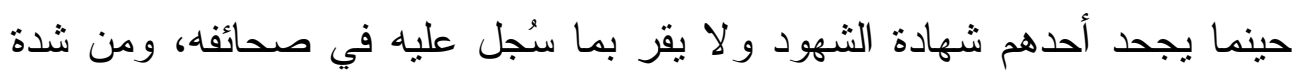

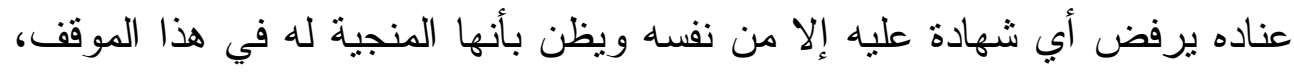

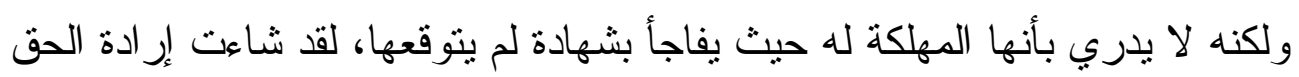

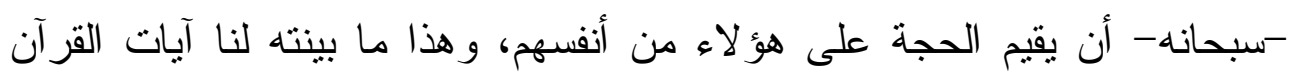

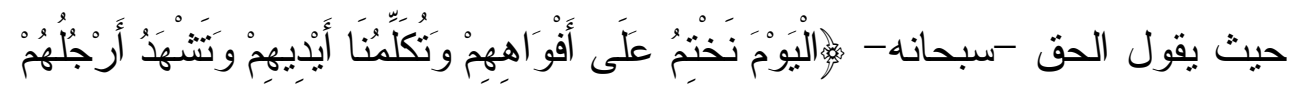

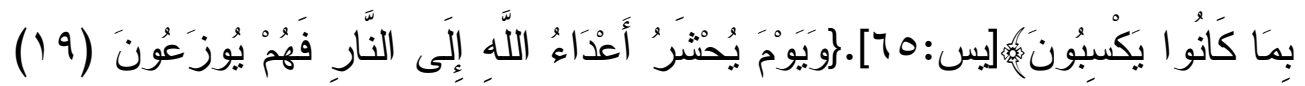

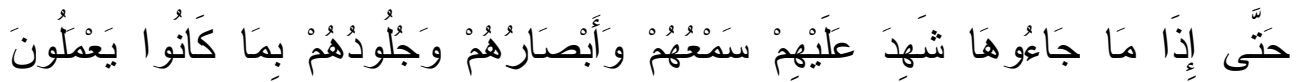

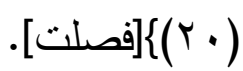

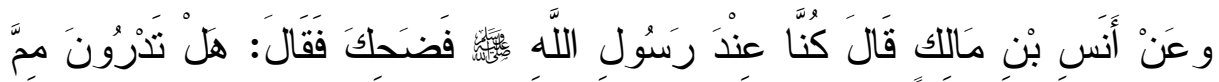

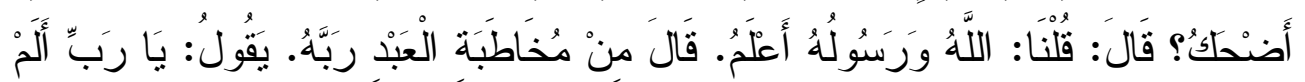

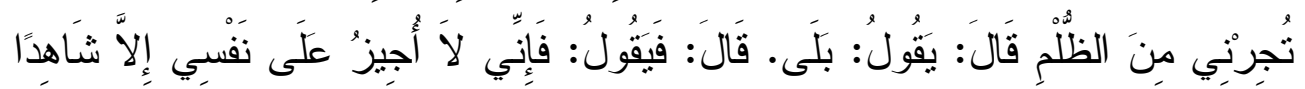

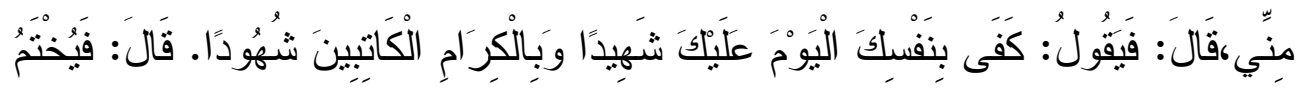

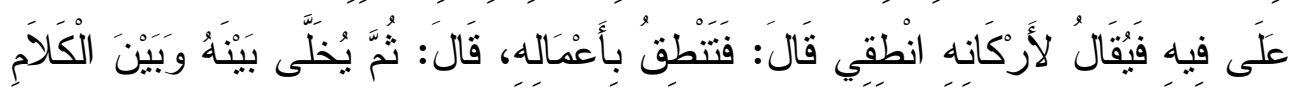

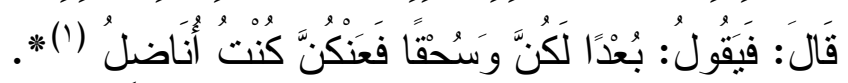

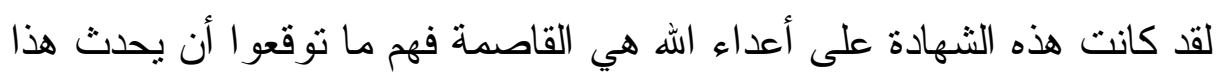

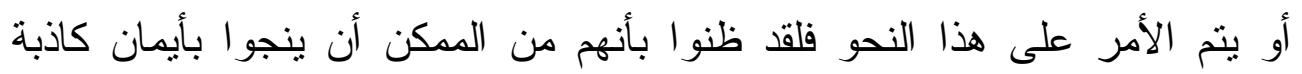


القيامة الكبرى (مشاهد ووقائع، دروس وعبر)

يلجئون إليها، أو بإنكار وجحود لثهادة الثهود ولكن لما جاءت الثهادة من

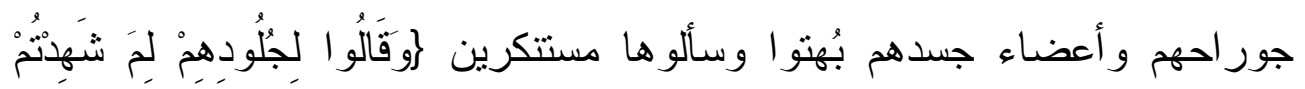

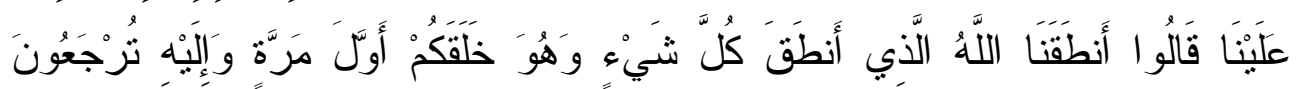
(فيلت] إنها قدرة الله -سبحانه- التي أنطقت كل شيء هي هي التي أقامت

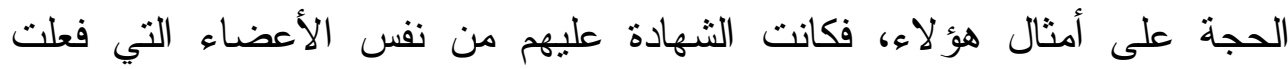
الذنب، و الجوارح التي اقترفت الإثم، فانقعت بعد ذلك حجتهم، وكانت فضيحتهم

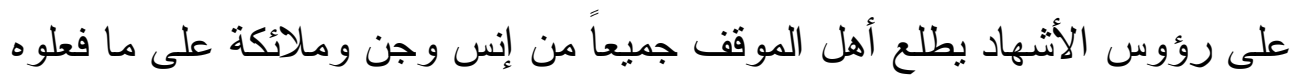

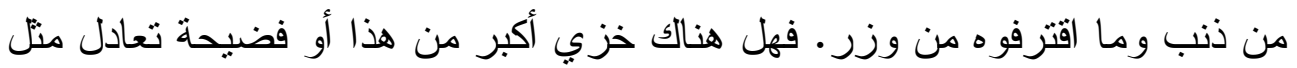

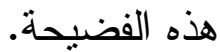

فتشتان ما بين حال هؤلاء في فضيحتهم وخزيهم و التتكيل بهم وبين حال

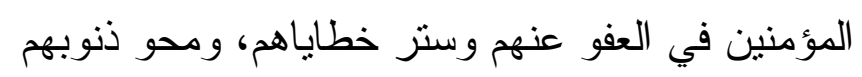

- يتضح من خلال هذه النصوص كذلك شدة غضب الله ونقمته على الكافرين

و الفاجرين و الفاسقين والمنافقين من الخلق، فإن فضيحتهم تكون على رؤوس

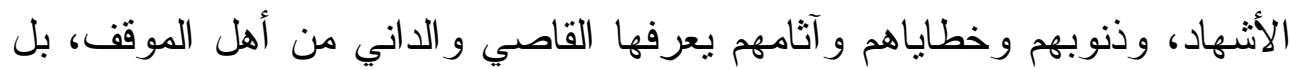
زيادة في خزيهم و التتكيل و النتهير بهم، نكون فضيحتهم من خلال جوارحهم التي ارتكبت الذنب و أعضاء جسدهم الني اقترفت هذه المنكرات و الآتام، من اليد و القدم و العين و الأذن و الفرج وسائر الأعضاء فهي التي تشهد وتثبت الجرم على صاحبها، فهل هناك خزي وفضيحة ومهانة أفظع من هذا. - بالإضافة إلى ذلك تتفاوت أحو ال العباد وطريقة حسابهم في هذا اليوم ففريق

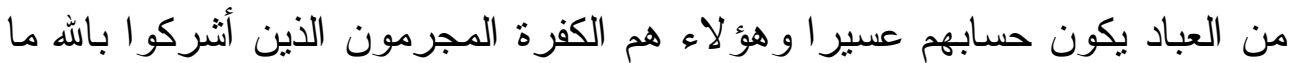
لم ينزل به سلطانا، وتمردو ا على شرع الله وكذبو ا الرسل. 
القيامة الكبرى (مشاهد ووقائع، دروس وعبر)

وبعض عصاة الموحدين قد يطول حسابهم ويعسر بسبب كثرة الذنوب و عظمها وبعض العباد يدخلون الجنة بغير حساب وهم فئة قليلة لا يجاوزون السبعين ألفا، و هم الصفوة من هذه الأمة، و القمم الثامخة في الإيمان و التقى و الصلاح و الجهاد.

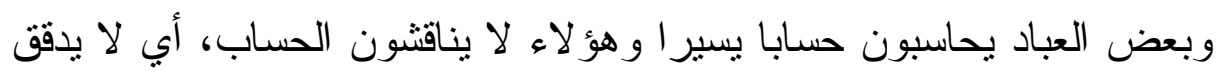
و لا يحقق معهم، و إنما تعرض عليهم ذنوبهم ثم يتجاوز لهم عنها، و هذا معنى قوله

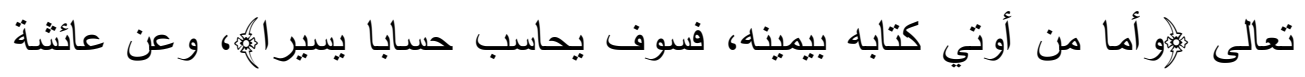

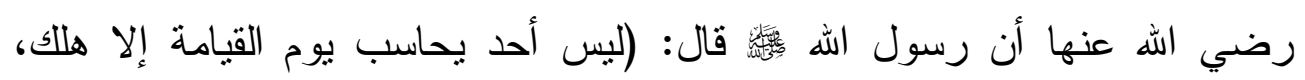

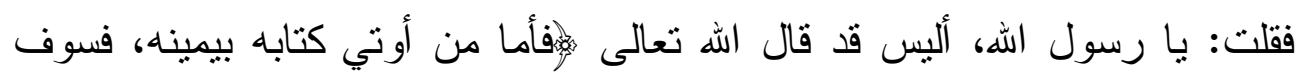

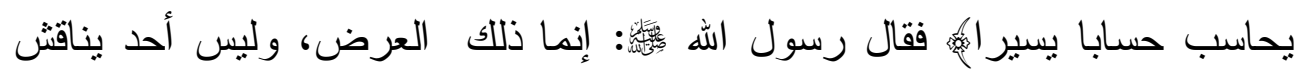

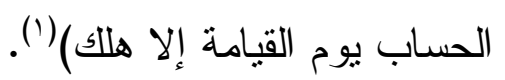

قال النووي في شرحه للحديث: معنى نوقش الحساب: استقصى عليه.

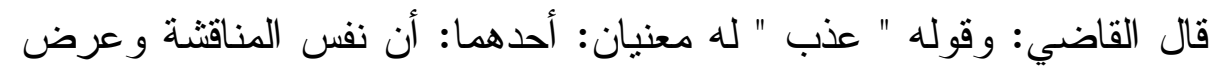
الذنوب و التوقيف عليها هو التعذيب لما فيه من النوبيخ.

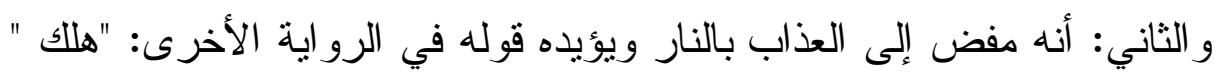
مكان عذب هذا كلام القاضي. قال النووي: وهذا الثاني هو الصحيح، ومعناه التقصير غالب في العباد فمن استقصى عليه، ولم بسامح هلك، ودخل هابل النار ، ولكن

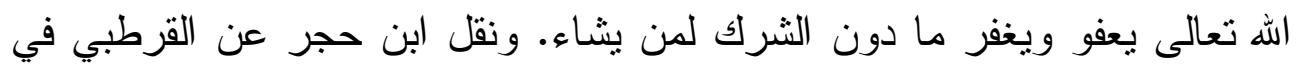

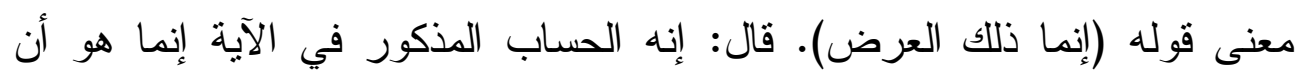

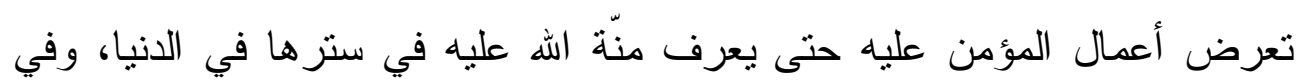


القيامة الكبرى (مشاهد ووقائع، دروس وعبر)

$$
\text { عفوه عنها في الآخرة:('). }
$$

هذا عن موقف أخذ الكتاب وتتاول الصحف وليت الأمر يقف عند هذا الحد، و إنما ما زال في يوم القيامة الكثير من المواقف التي نتيب من أجلها رؤوس

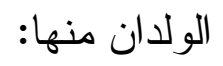

\section{القصاص بين العباد}

إن يوم القيامة يوم الفصل و القضاء و الحساب و الجزاء، ويوم للقصاص بين العباد فإن الخلق يحشرون ويجمعون في هذا اليوم، ومن تمام العدل أن ترد الحقوق

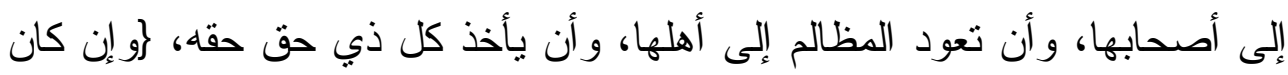

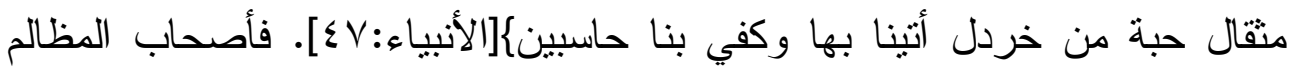
يطالبون بمظالمهم و القتلة و المجرمون وسفاكو ا الدماء يحشرون للقصاص منهم، بل إن البهائم العجماء لتحشر كذلك ليقيم الحق سبحانه- ميزان العدل و القصاص فيما بينها. ونصوص الأحاديث تتبت هذا فعن أبي هريرة رضي الله عنه أن رسول الله

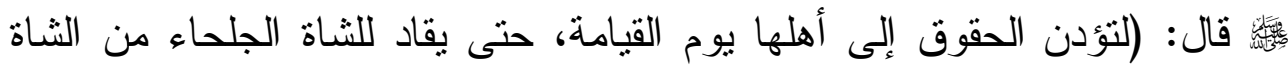
القرناء) رو اه مسلم (؟) المودن و الذي يقذف مملوكه بالزنا يقام عليه الحد في يوم القيامة إن كان كاذبا فيما

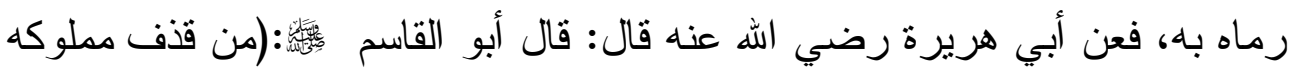

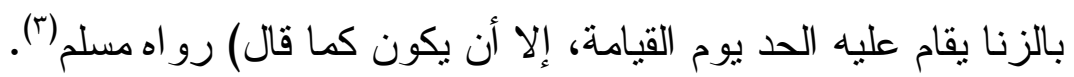
وثروة الإنسان في يوم القيامة ور أس ماله هي الحسنات، فإذا كانت عليه مظالم 
للعباد فإنهم يأخذون من حسناته بقدر ما ظلمهم، فإن لم يكن له حسنات أو فنيت

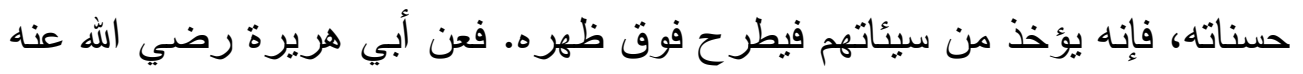

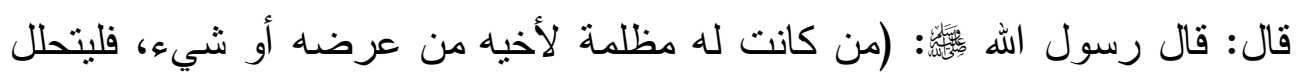

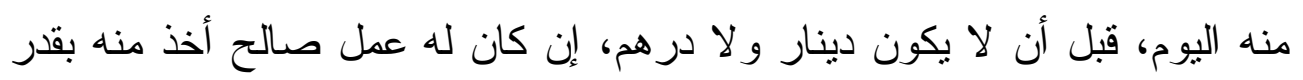

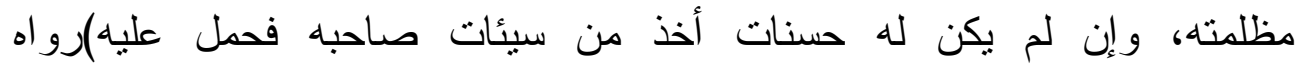

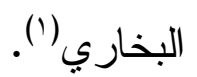

و المفلس هو من يأخذ الناس حسناته، ثم يقذفون بسيئاتهم فوق ظهره، كما جاء

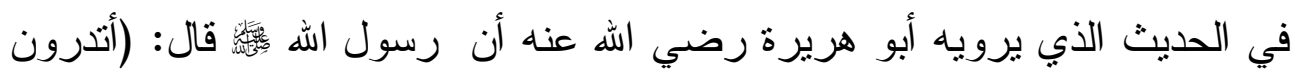

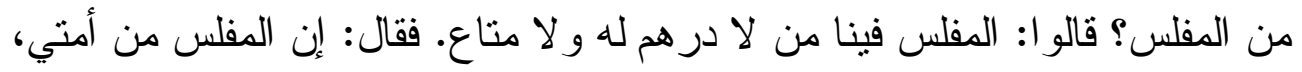

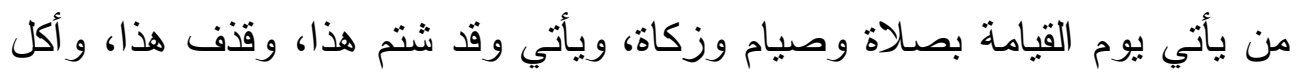

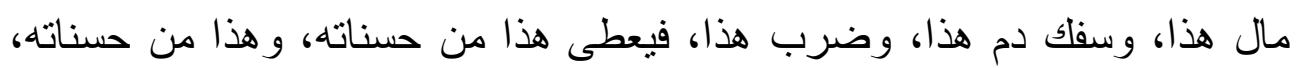

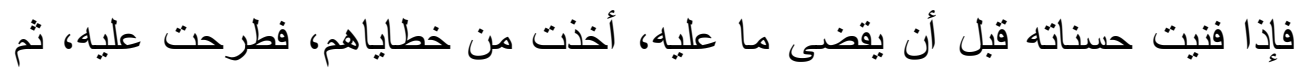
طرح في النار )رو اه مسلم (r). و المدين الذي مات وللناس في ذمته أمو ال يأخذ أصحاب الأمو ال من حسناته

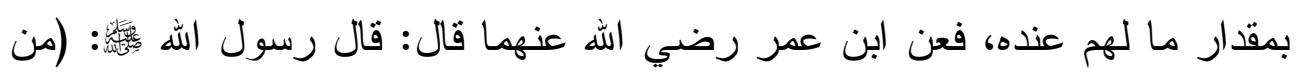

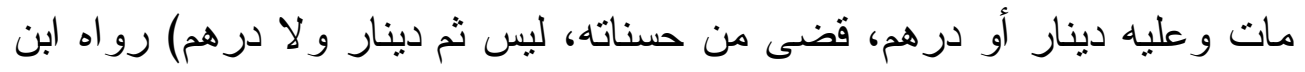

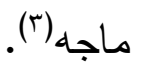
و إن كان بين العباد مظالم منبادلة اقتص لبعضهم من بعض، فإن تساوى ظلم كل واحد للآخر كان كفافا لا له و لا عليه، وإن بقي لبعضهم حقوق عند الآخرين

$$
\begin{aligned}
& \text { ( (1) البخاري. كتاب و المظالم و الغصب. حديث رقم 979 Y. }
\end{aligned}
$$

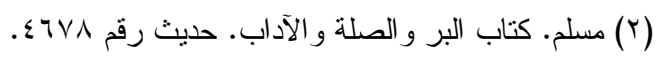

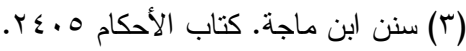


أخذها، فعن عائشة رضي الله عنها قالت: جاء رجل فقعد بين يدي الرسولدأس فقال: يا رسول الله، إن لي مملوكين يكذبونني، ويخونني، ويعصونني، و وانتتهم

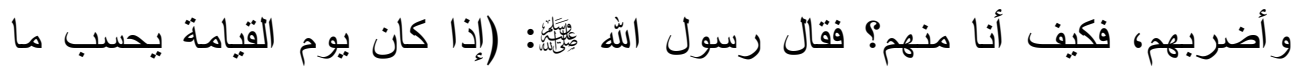

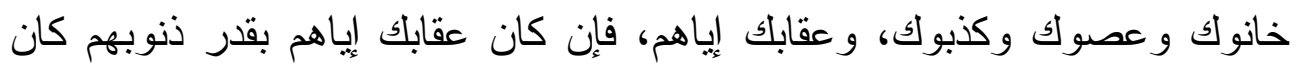
كفافا لا للك و لا عليك. و إن كان عقابك إياهم دون ذنبهم كان فضلا للك، و إن كان عقابك إياهم فوق ذنوبهم، اقتص لهم منك الفضل). فتتحى الرجل وجعل يهتق ويبكي. فقال الرسول

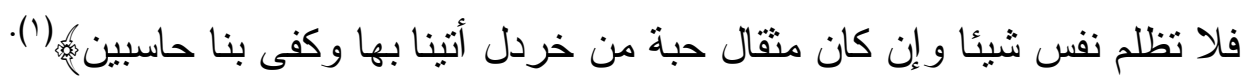
نخلص من خلال هذه النصوص لما يلي:

-أن القصاص أمر لا بد منه لرد المظالم إلى أصحابها. ولتعود الحقوق إلى

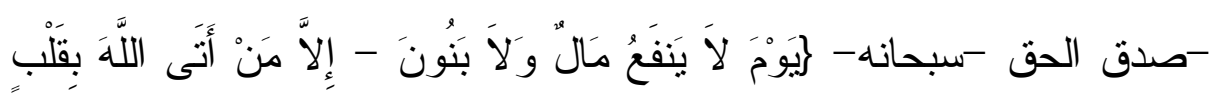

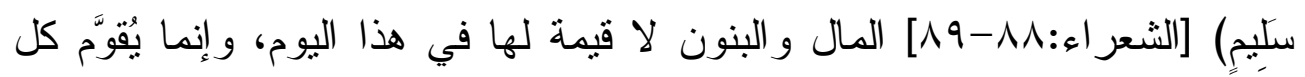
شيء بالحسنات و السيئات فهي بمثابة العملة الوحيدة المعترف بها و الصالحة للتداول في هذا اليوم، وقيمة المرء في سوق القيامة على قدر ما يملكه من الحسنات، وما وقى منه نفسه من السيئات، ولذلك فإن من مؤشرات الإفلاس في هذا لها لئه اليوم تآكل

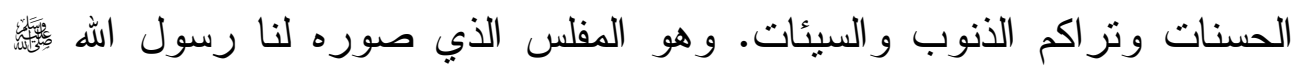
الذي دخل الموقف بحسنات كالجبال ولكنه خرج من ذلك كله صفر اليدين، بل وهر محملاً بذنوب العباد و آثامهم. 
القيامة الكبرى (مشاهد ووقائع، دروس وعبر)

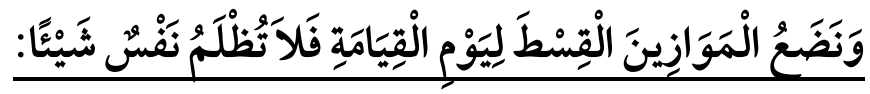

لكي لا تبقى لأحد حجة، ولتتطع أعذار أصحاب الأعذار، وليتحقق العدل

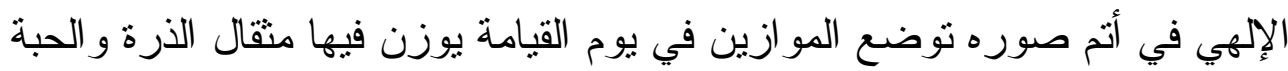

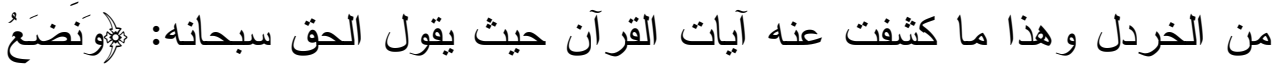

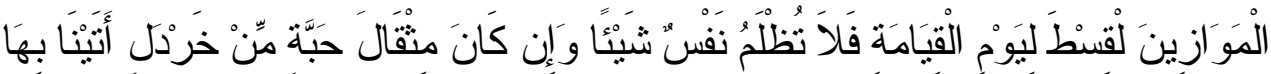

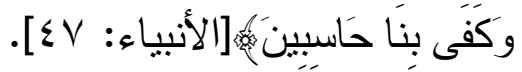

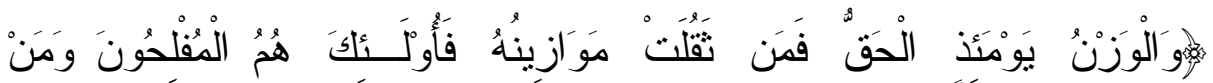

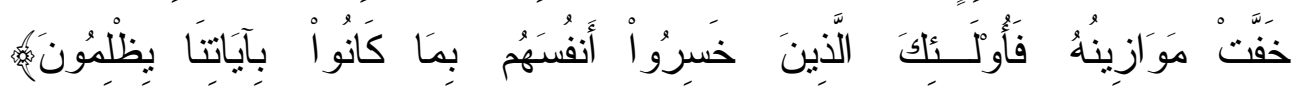

$$
\text { [الأعر اف: موان: }
$$

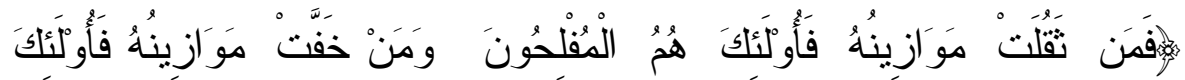

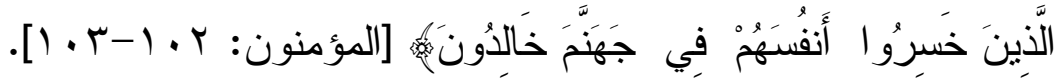

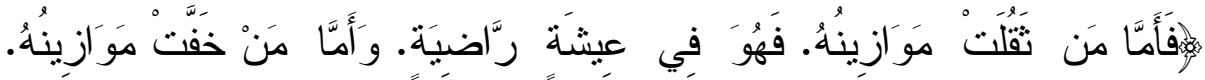

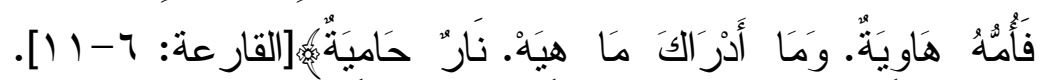
إن هذا الميزان ينصب في ختام ذلك اليوم لوزن أعمال العباد و إقامة الحجة عليهم أمام الله سبحانه وتعالى. يقول القرطبي:و إذا انقضى الحساب كان بعده وزن لهن

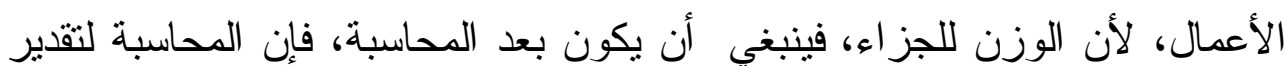
الأعمال، و الوزن لإظهار مقادير ها ليكون الجز اء بحسبها ('). وقد دلت النصوص على أن الميزان ميزان حقيقي، لا يقدر قدره إلا الله، فقد روى الحاكم عن سلمان عن النبي السماوات والأرض لوسعت. فتقول الملائكة: يا رب لمن يزن هذا؟ فيقول الله 
القيامة الكبرى (مشاهد ووقائع، دروس وعبر)

تعالى: لمن شئت من خلقي. فتقول الملائكة: سبحانك ما عبدناك حق عبادتك).(') و هو ميزان دقيق لا يزيد و لا ينقص يوزن فيه منقال الحبة و الخردل، وما هو

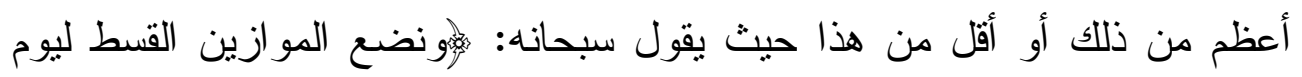
القيامة فلا نظلم نفس شيئا وإن كان منقال حبة من خردل أنينا بها وكفى بنا

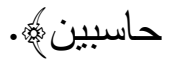

\section{اختلاف العلماء في الميزان}

وقد اختلف أهل العلم في وحدة الميزان وتعدده، فذهب بعضهم إلى أن لكل

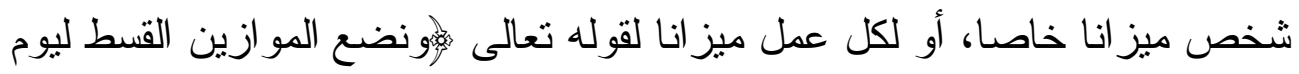

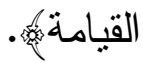

وذهب آخرون إلى أن الميزان واحد وأن الجمع في الآية إنما هو باعتبار تعدد

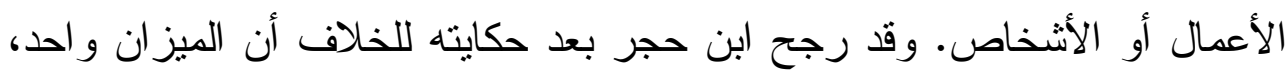

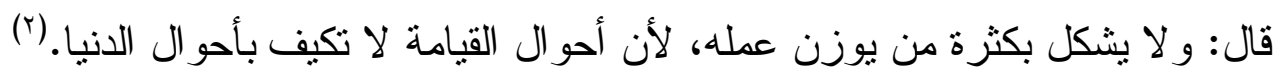
وقال السفاريني: قال الحسن البصري: لكل واحد من المكلفين ميزان. قال بعضهم: الأظهر إثبات موازين القيامة لا ميزان واحد، لقوله نعالى:

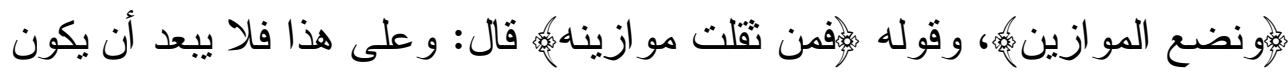

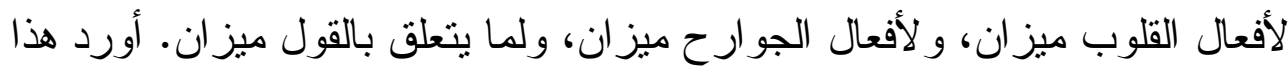
ابن عطية وقال: الناس على خلافه، و إنما لكل واحد وزن مختص به، و والميزان و احد، وقال بعضهم إنما جمع الموازين في الآية الكريمة لكثرة من توزن أعمالهم. 
و هو حسن. (')

و الميزان عند أهل السنة ميزان حقيقي نوزن به أعمال العباد وخالف في هذا

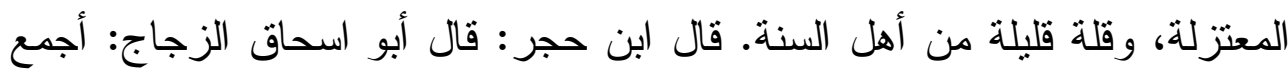

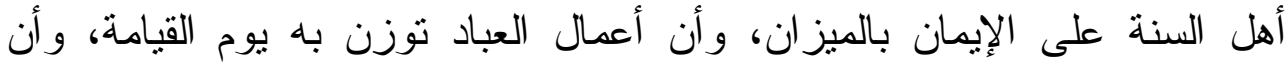

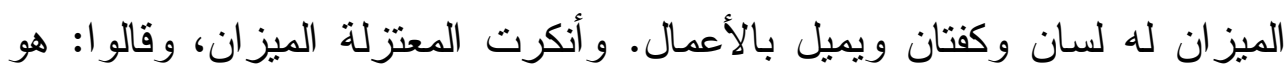

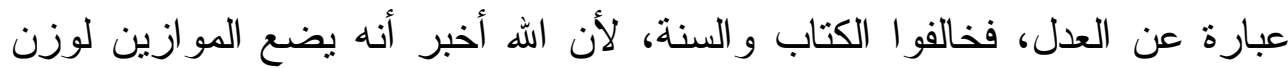

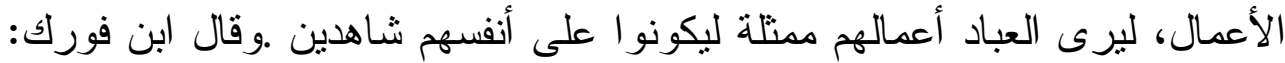

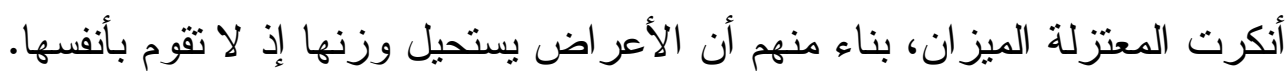
قال: وقد روى بعض المتكلمين عن ابن عباس أن اله تعالى يقلب الأعر اض أجساما

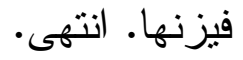
وقد ذهب بعض السلف إلى أن الميزان بمعنى العدل و القضاء، وعز ا الطبري القول بذلك إلى مجاهد. و الر اجح ما ذهب إليه الجمهور ـ وذكر الميزان عند الحسن

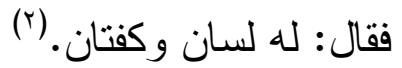
و عز ا القرطبي تفسير الميزان بالعدل إلى مجاهد و الضحاك و الأعشش (َ). ولعل

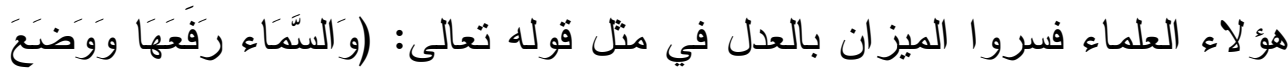

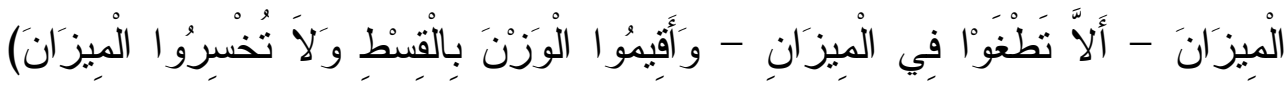

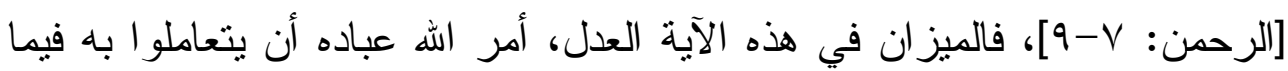
بينهم، أما الميزان الذي ينصب في يوم القيامة فقد تواترت بذكره الأحاديث، وأنه

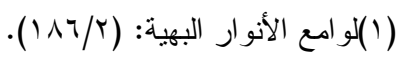

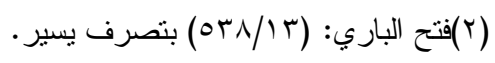

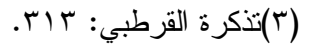


ميز ان حقبقي، وهو ظاهر القرآن (').

وقد رد الإمام أحمد على من أنكر الميزان بأن الله تعالى ذكر الميزان في

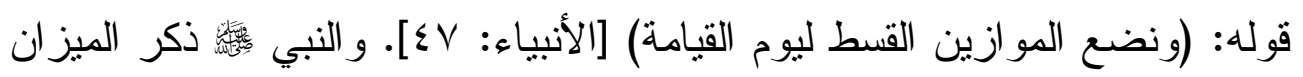

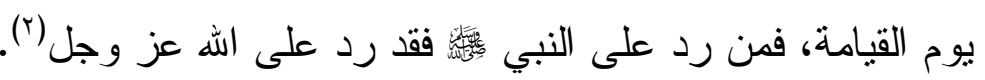

وقد استدل شيخ الاسلام بن تيمية على أن الميزان غير العدل، وأنه ميزان

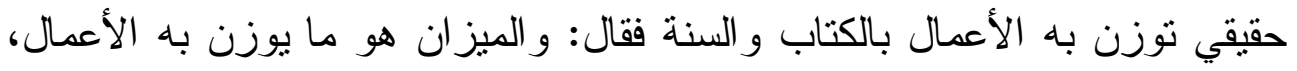

و هو غير العدل كما دل على ذلك الكتاب والسنة مثل قوله تعالى زولفمن ثقلت

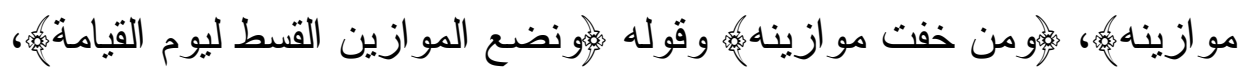
وفي الصحيحين عن النبي

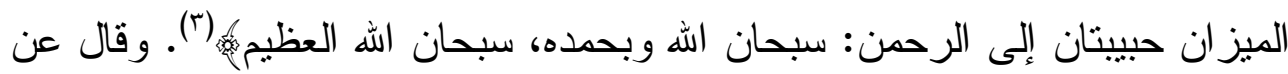

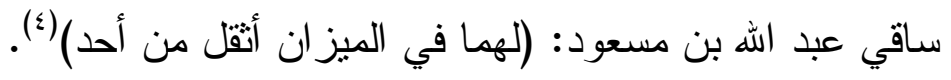
وفي الترمذي وغيره حديث البطاقة، وصححه الترمذي و الحاكم و غير هما عَنْ

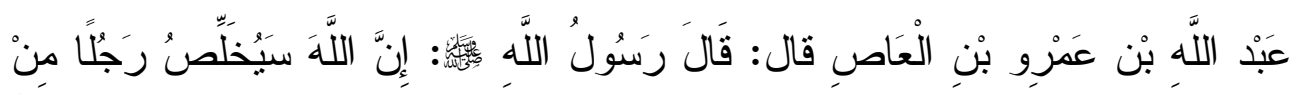

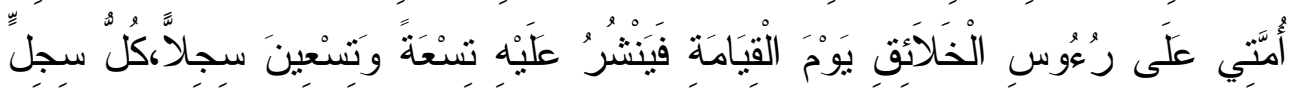

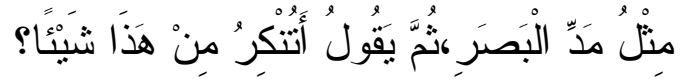

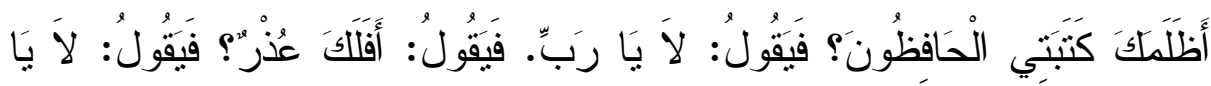

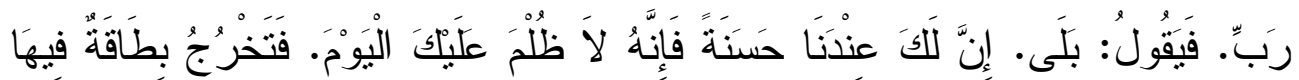

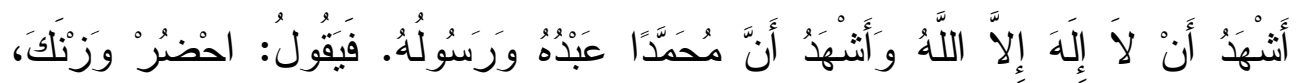

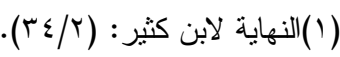

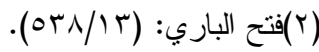

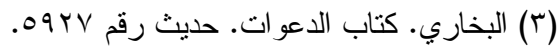$$
\text { ( ( ) المسند للإمام أحمد بن حنبل مسند العشرة المبشرين بالجنة. حديث رقم AVY. }
$$ 
القيامة الكبرى (مشاهد ووقائع، دروس وعبر)

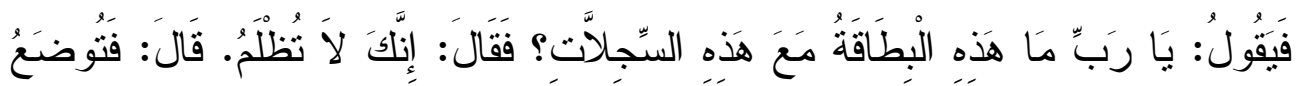

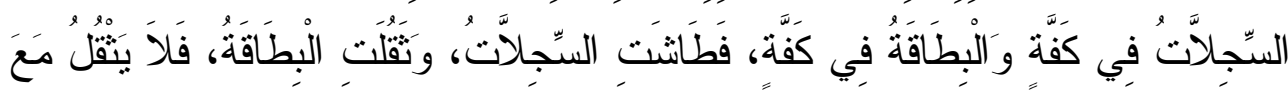

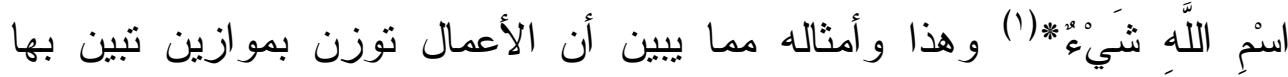
رجحان الحسنات على السيئات وبالعكس، فهو ما به تبين العدل و المقصود بالوزن لهن

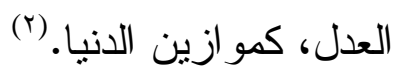

\section{هذا وقد اختلف آراء أهل العلم في الموزون ذلك اليوم على أقوال:}

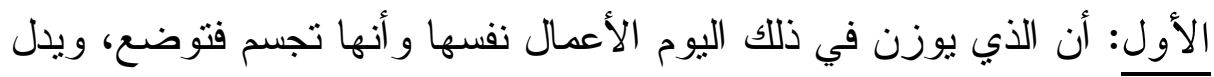

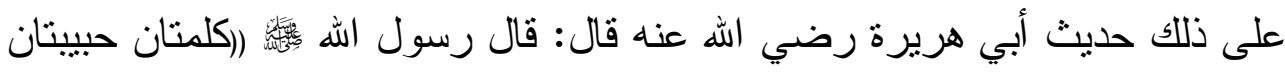

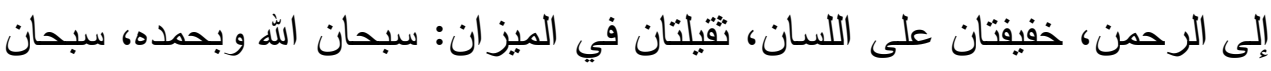
الله العظيم)) رو اه البخاري(").

وقد دلت نصوص كثيرة على أن الأعمال تأتي في يوم القيامة في صورة الله

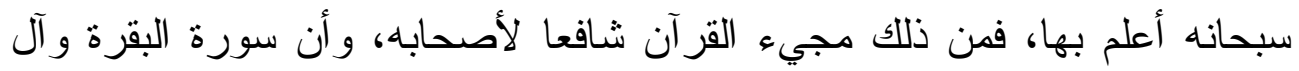

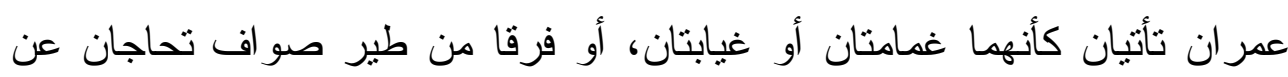
أصحابهما.

وروى أبو أمامة قال: سمعت رسول اله

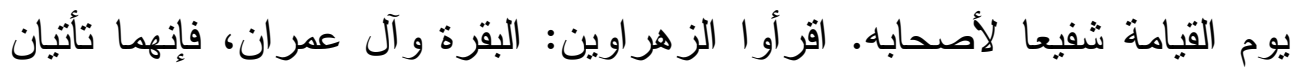
كأنهما غمامتان أو غيابتان أو فرقان من طير صو اف تحاجان لون عن أصحابهما) رواه

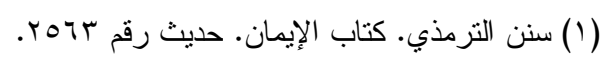

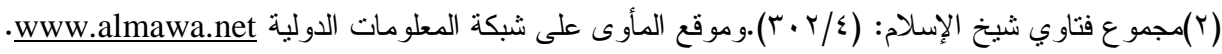

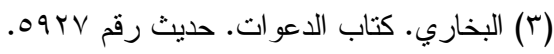

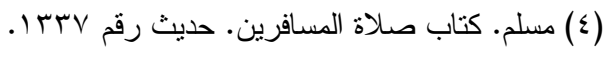


و هذا القول رجحه ابن حجر العسقلاني ونصره، فقال: والصحيح أن الأعمال

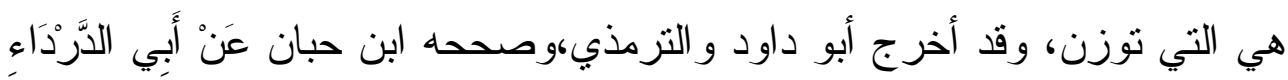

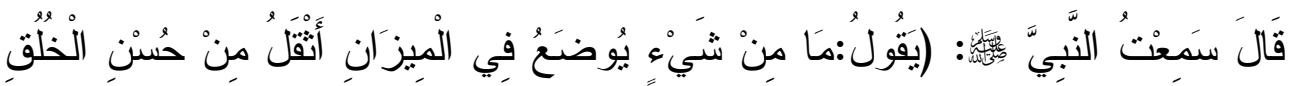

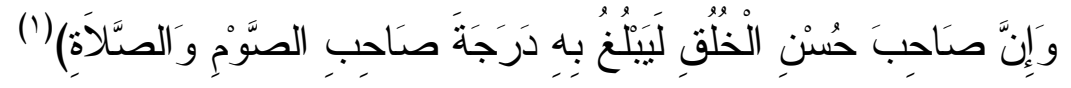

الثاني: أن الذي يوزن هو العامل نفسه، فقد دلت النصوص على على أن العباد

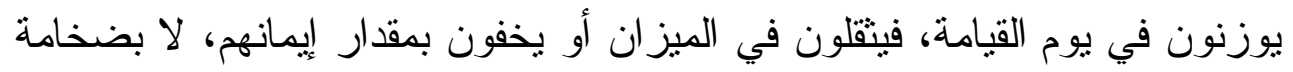

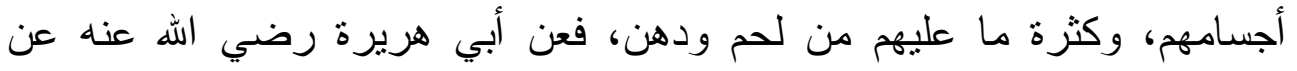

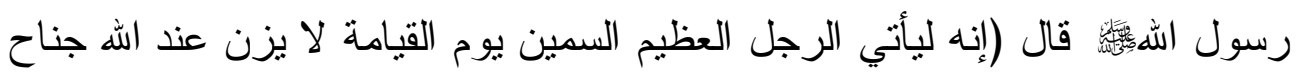

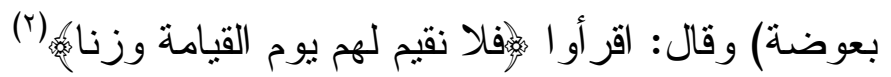
وعن ابن مسعود أنه كان رقيق الساقين فجعلت الريح تلقيه، فضحك القوم منه، فقال رسول الله نفسي بيده لهما أنقل في الميزان من أحد (؟). الثالث : أن الذي يوزن إنما هو صحائف الأعمال، فقد روى التزمذي عن

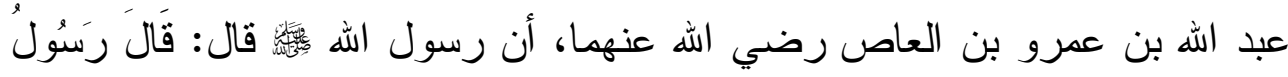

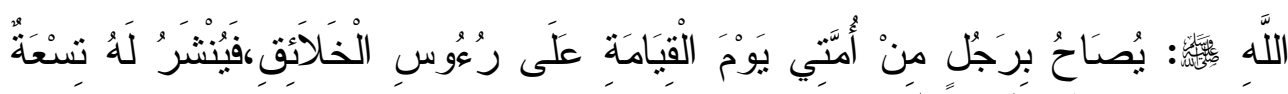

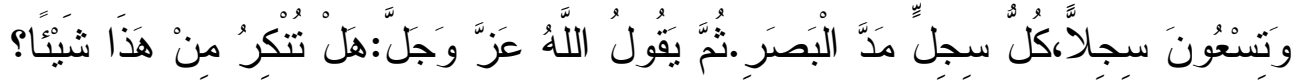

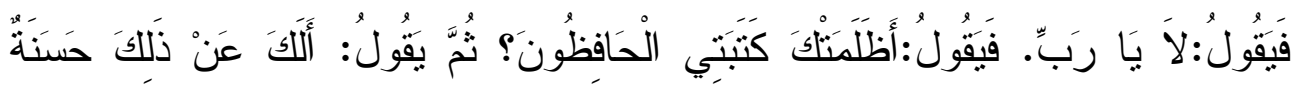

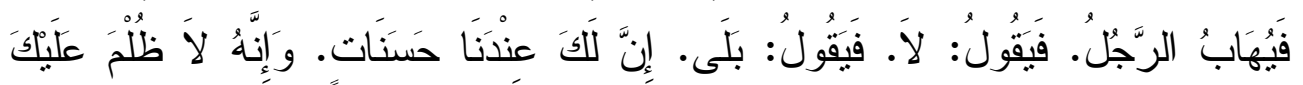

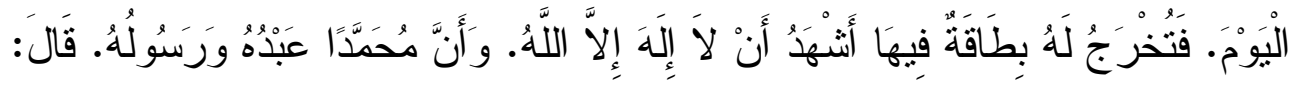




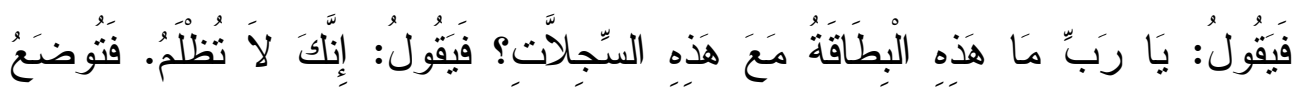

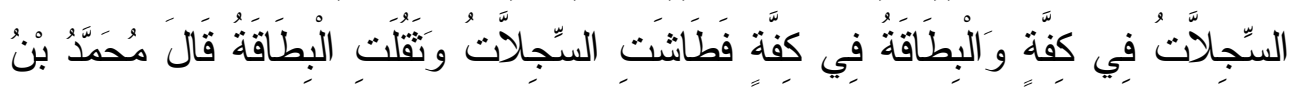

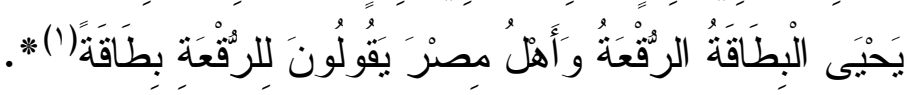
وقد مال القرطبي و السفاريني إلى هذا القول. ولعل الحق أن الذي يوزن هو العامل وعمله وصحف أعماله، فقد دلت النصوص التي سقناها على أن كل واحد من هذه الثناثة يوزن، ولم تتف النصوص المثتنة لوزن الواحد منها أن غيره لا يوزن، فيكون مقتضى الجمع بين النصوص إثبات الوزن للثلاثة المذكورة

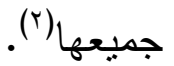

\section{الأعمال التي تثثل الميزان}

أثقل ما يوضع في ميزان العبد حسن الخلق، فعن أبي الدرداء عن النبي قال: (إن أنقل شيء يوضع في ميزان العبد يوم القيامة خلق حسن، وإن الله يبغض الفاحش البذيء) رو اه الترمذي وقال: هذا حديث حسن صحيح(َ). و عن أبي هريرة رضي الله عنه أن النبي اللسان، ثقيلتان في الميزان حبييتان إلى الرحمن: سبحان الله وبحمده سبحان الله

\section{العظيم) رو اه البخاري ومسلم (ء).}

و عن أبي مالك الأشعري قال: قال رسول الله و الحمد لله تملأ الميزان، وسبحان الله والحمد اله تملآن (أو تملأ) ما بين السماء

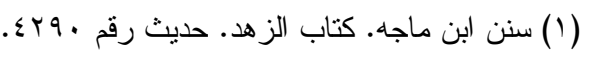

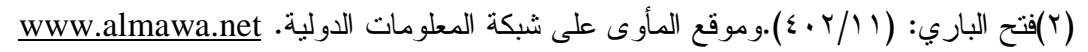

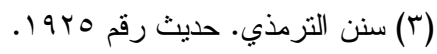

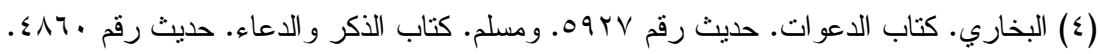




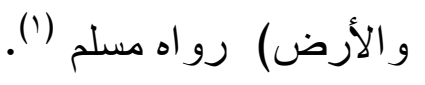

وعن أبي هريرة رضي اله عنه عن النبي الله إيمانا و احتسابا وتصديقا بو عده، كان شبعه وريه ورئه وروثه في ميز انه يوم القيامة) رواه البخاري و النسائي و أحمد (ץ).

\section{حساب الكفار في يوم القيامة:}

\section{هل يسأل الكفار؟ولماذا يسألون؟}

ترى هل يُسأل الكفار في يوم القيامة ويُحاسبون على ما قدموه من أعمال؟

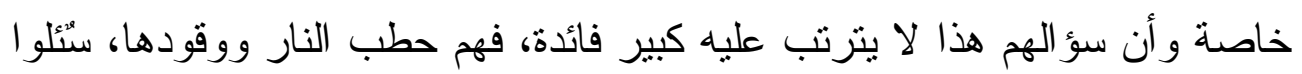
أم لم يُسألو ا ! وذلك لكفر هم بالله سبحانه، وتكذيبهم برسله و أنبيائه.

اختلف العلماء في ذلك: هل يحاسبون ويسألون؟ أم يُؤمر بهم إلى النار من غير بهاه

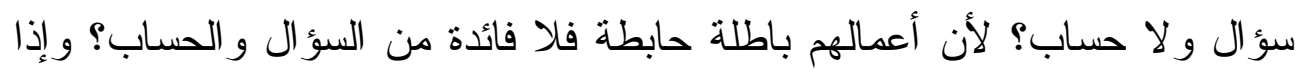

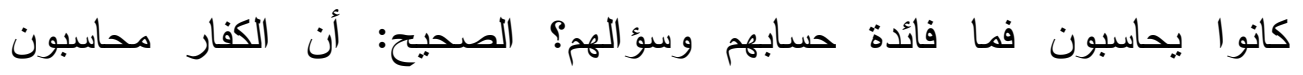

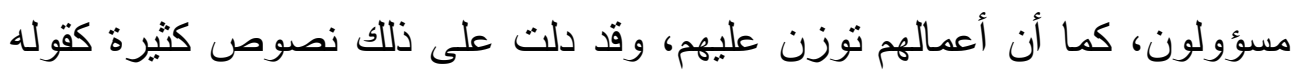

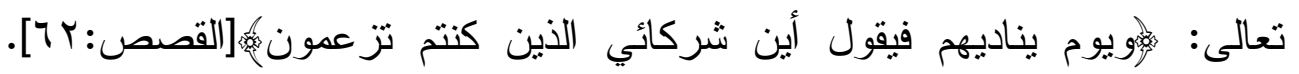

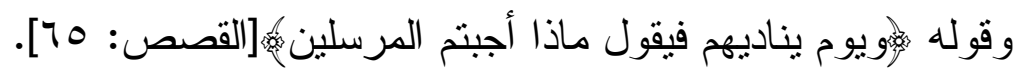
وقوله إوفأما من نقلت موازينه، فهو في عيشة راضية، و أما من خفت مو ازينه

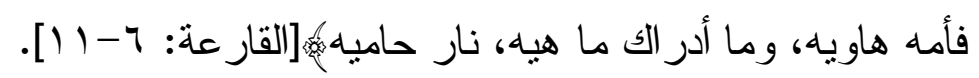
وقوله تعالى خازومن خفت موازينه فأولئك الذين خسروا أنفسهم في جهنم خالدون، تلفح وجوههم النار وهم فيها كالحون،ألم تكن آياتي تتلى عليكم فكنتم بها

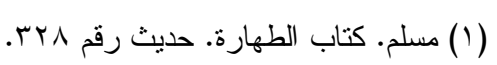

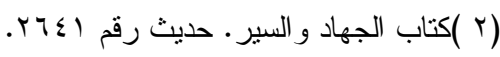


القيامة الكبرى (مشاهد ووقائع، دروس وعبر)

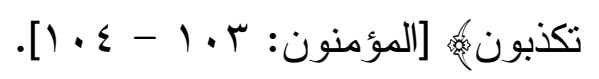

\section{أما لماذا يحاسبون وتوزن أعمالهم مع أن أعمالهم حابطة مردودة، فلأمور}

الأول: إقامة الحجة عليهم، و إظهار عدل الله فيهم، و لا أحد أحب إليه العذر

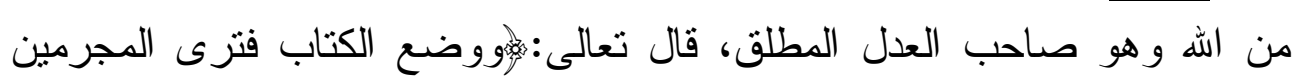

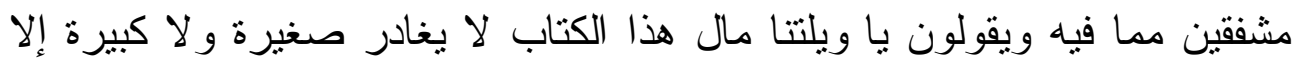
أحصاها ووجدو ا ما عملو ا حاضر ا و لا يظلم ربك أحداه.

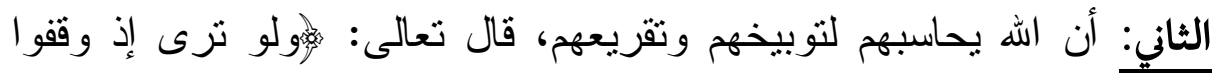
على ربهم قال أليس هذا بالدق قالوا بلى وربنا قال فذوقوا العذاب بما كنتم

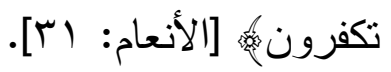
الثالث: أن الكفار مكلفون 1 الثريعة كما هم مكلفون بفروعها - على الر اجح

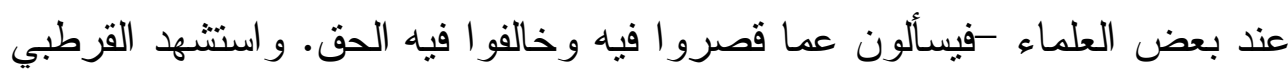

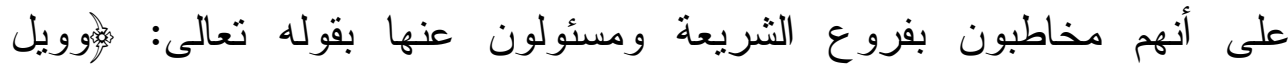

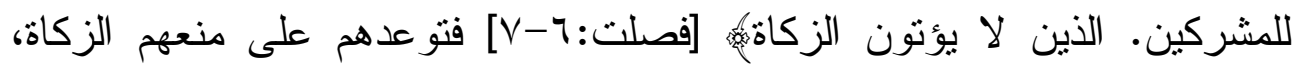

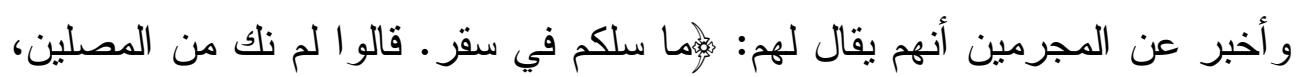
ولم نلك نطعم المسكين وكنا نخوض مع الخائضين، وكنا نكذب بيوم الدينمئ. [المدثر : .[ $[\leqslant 7-\varepsilon\}$

الرابع: أن الكفار يتفاوتون في كفرهم وذنوبهم ومعاصيهم، ويحلون في النار بمقدار هذه الذنوب، فالنار دركات بعضها تحت بعض، وكلما كان المرء أثند كفر أ كلما كان أثند عذاباً. وذكر ابن تيمية أن الحساب لبيان مراتب العذاب لا لأجل دخول الجنة كما أن 
القيامة الكبرى (مشاهد ووقائع، دروس وعبر)

أبا طالب أخف عذابا من أبي لهب. ويذكر القرطبي وجهين لوزن الأعمال الأول:

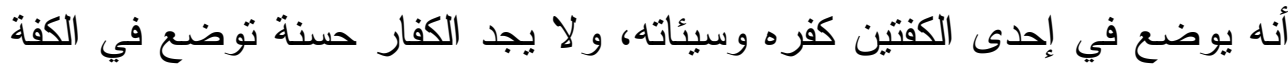
الأخرى، فترجح كفة السيئات.

و الثاني: أن حسنات الكفار من صلة رحم وصدقة ومواساة الناس توضع في كفة الحسنات، ولكن كفة السيئات ترجح بسبب كفره وشركه. و الوجه الأول هو

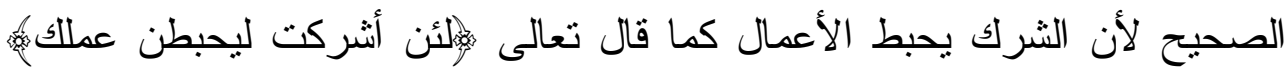
[الزمر :70]

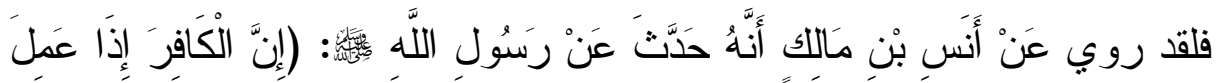

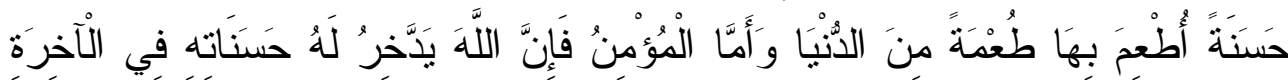

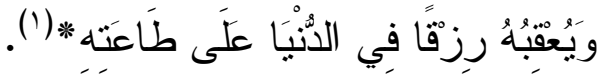
وبعد تقرير سؤال الكفار فيما سبق، فكيف توجه النصوص الدالة على خلاف

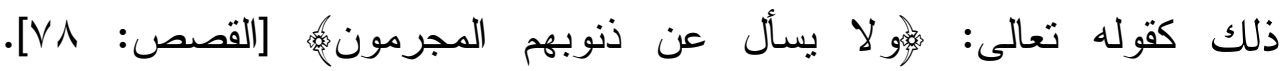

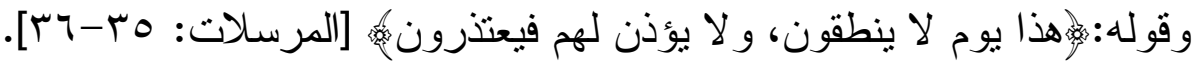
و الجواب على ذلك أنه ليس بين هذه النصوص إن شاء الله تعالى تعارض وقد وفق أهل العلم بينها بوجوه عدة: الأول: أن الكفار لا يسألون سؤال شفاء ور احة، و وإنما بسألون سؤال تقريع وتوبيخ.

الثاني: أنهم لا يسألون سؤال استقهام، لأنه تعالى عالم بكل أعمالهم، و إنما

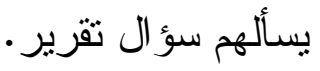
الثالث: أنهم يسألون في يوم القيامة في موطن دون موطن، قال القرطبي: ( (1) مسلم. كتاب صفة القيامة و الجنة و النار • حديث رقم بr.0. 
"القبامة مو اطن، فموطن يكون فيه سؤ ال وكلام، وموطن لا يكون ذلك ". (')

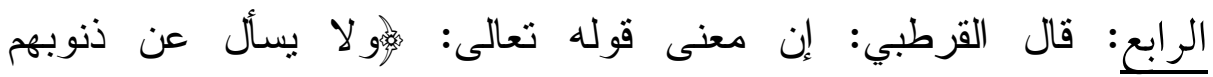

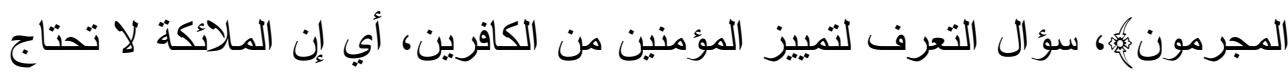

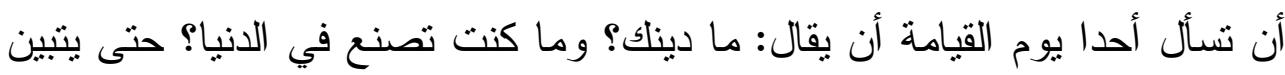

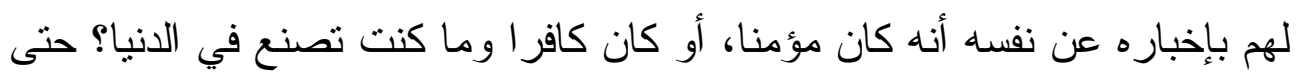

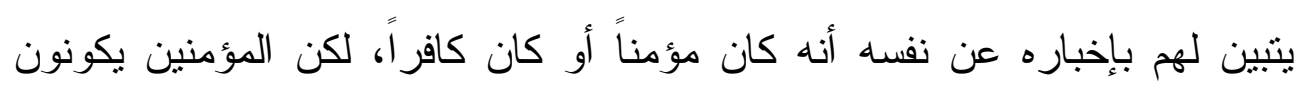

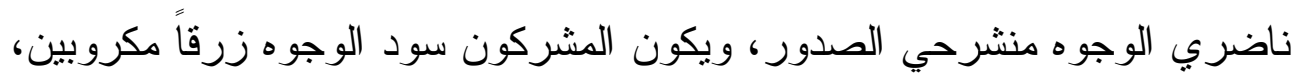
فهم إذا كلفو اسوق المجرمين إلى النار، وتميزهم في الموقف كفتهم مناظرهم عن

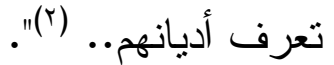

\section{تصوير المحاسبي لأحداث يوم القيامة:}

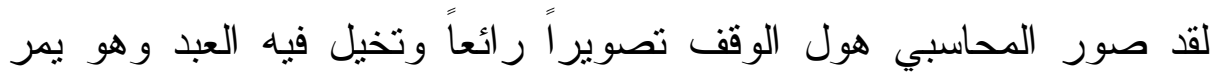

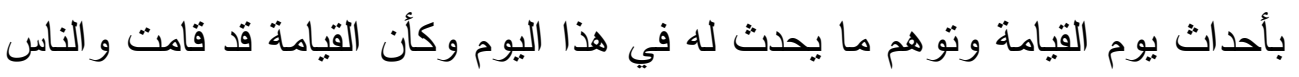

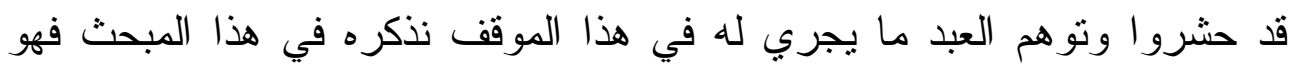

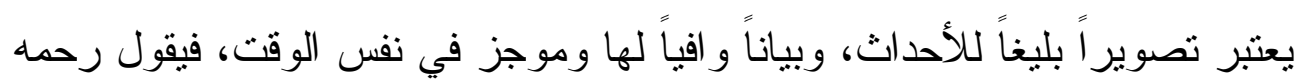

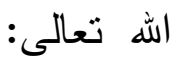

حتى إذا تكاملت عدة الموتى، وخلت من سكانها الأرض و السماء فصاروا خامدين بعد حركاتهم، فلا حس يسمع، و لا شخص يرى، وقد بقي الجبار الأعلى ونى

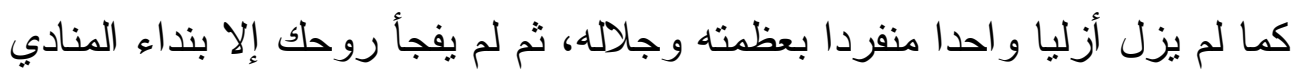
لكل الخلائق معك للعرض على الله عز وجل بالذل و الصغار منك ومنهم. فتوهم لهم

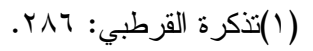

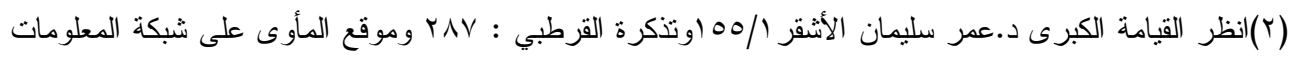
الدولية. 
القيامة الكبرى (مشاهد ووقائع، دروس وعبر)

كيف وقوع الصوت في مسامعك وعقلك، وتفهم بعقلك كأنك تدعى إلى العرض إلى

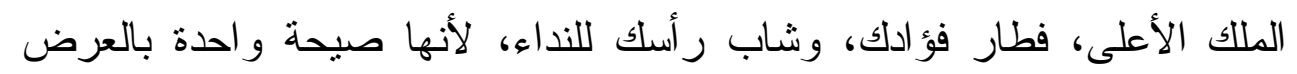

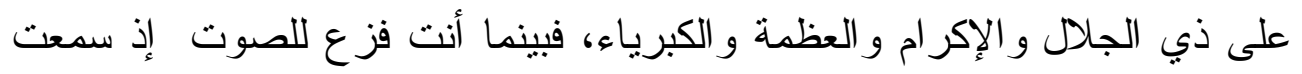
بانفر اج الأرض على رأسك، فوثبت مغبر ا من قرنك إلى قدمك بغبار قبرك، ولى قائم

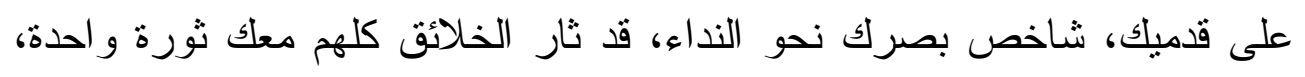
مغبرون من غبار الأرض التي طال فيها بلاؤهم.

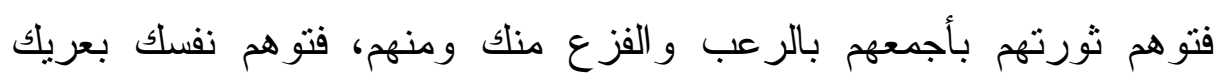

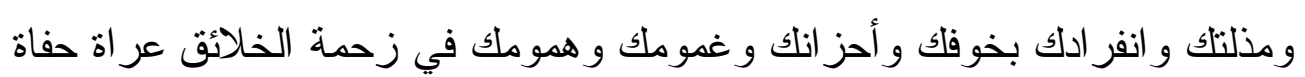

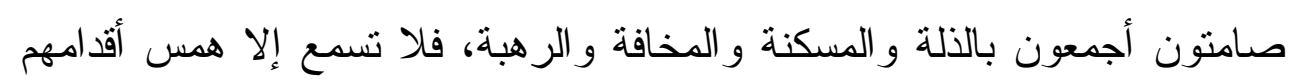

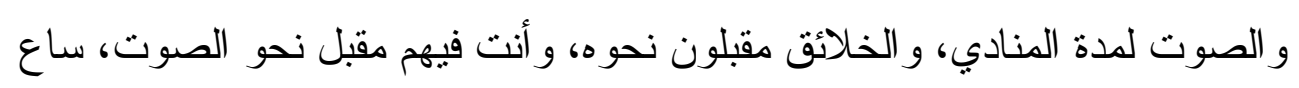
بالخشوع و الذلة، حتى إذا و افيت الموقف ازدحمت الأمم كلها من الجن و الإنس عر اة حفاة، قد نزع الملك من ملوك الأرض ولزمتهم الذّلة و والصغخار، فهم أذل أهل

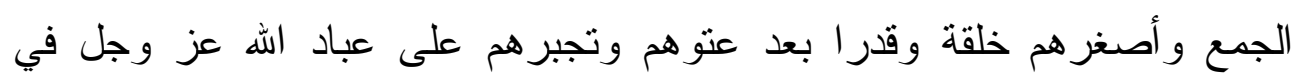

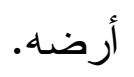

ثم أقبلت الوحوش من البراري وذرى الجبال منكسة رؤوسها، ذليلة ليوم

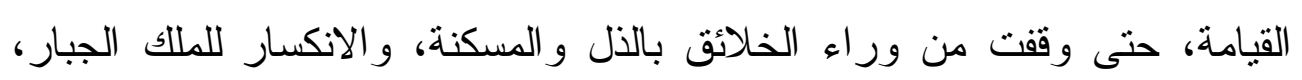

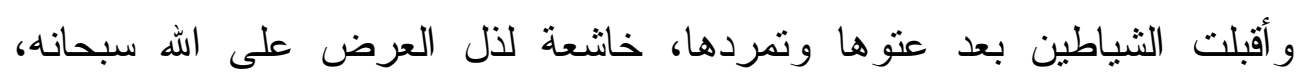

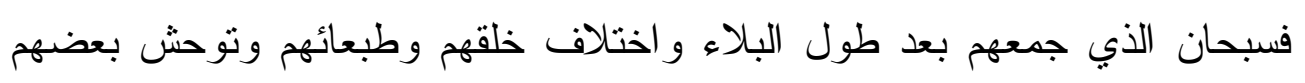

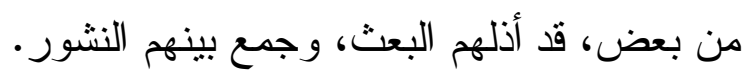

حتى إذا تكاملت عدة أهل الأرض من إنسها وجنها وشياطينها ووحوشها لبها

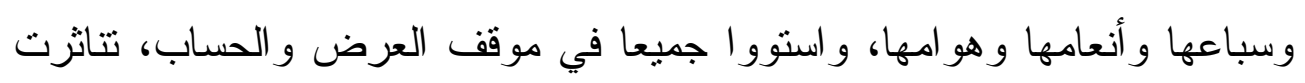


القيامة الكبرى (مشاهد ووقائع، دروس وعبر)

نجوم السماء من فوقهم، وطمست الثمس و القمر، و أظلمت الأرض بخمود سر اجها،

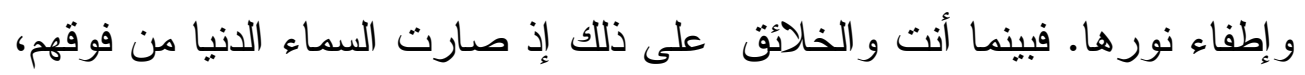
فدارت بعظمها من فوق رؤوسهم، وذللك بعينك نتظر إلى هول ذلاء دلك، ثم انثقت

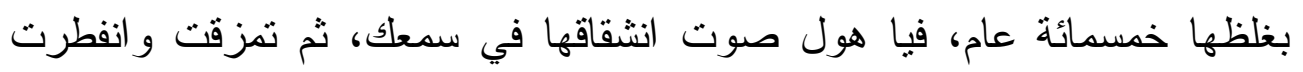
بعظيم هول يوم القيامة، و الملائكة قيام على أرجائها وهي حافات ما يتشقق بهات

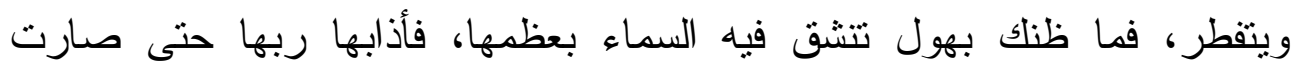

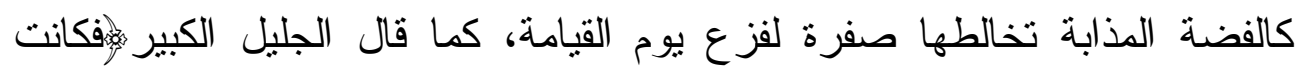

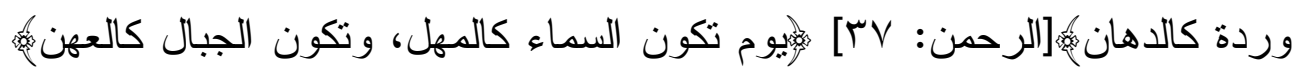

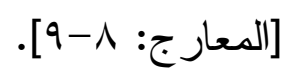

فبينما ملائكة السماء الدنبا على حافتها، إذا انحدروا محشورين إلى الأرض

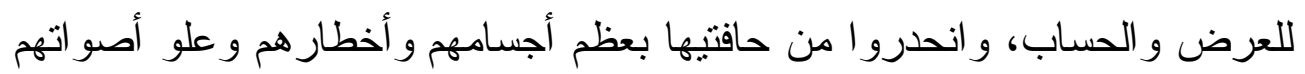

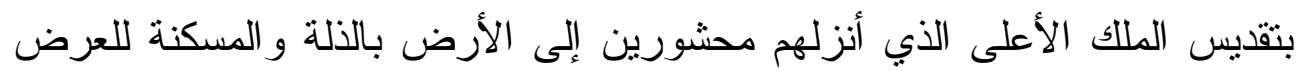
عليه و السؤ ال بين يديه.

فتو هم تحدرهم من السحاب، بعظيم أخطار هم، وكبير أجسامهم، وهول

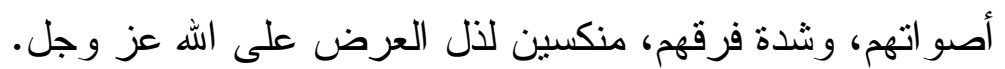

فيا فزعك، وقد فزع الخلائق مخافة أن يكونو ا أمروا بهم، مسألتهم إياهم: أفيكم

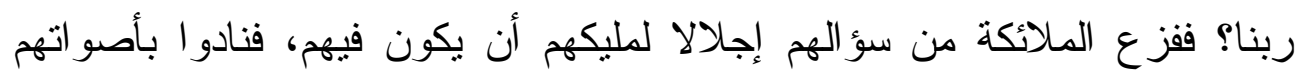
تنزيلا لما توهمه أهل الأرض :سبحان ربنا ليس هو بيننا فهو آت، حتى أخذوا مصافهم، محدقين بالخلائق، منكسين رؤوسهم في عظم خلقهم بالذل و المسكنة و الخشوع لربهم، ثم كل شيء على ذللك، وكذلك إلى السماء السابعة، كل أهل سماء مضعفين بالعدد و عظم الأجساد، وكل أهل سماء محدقين بالخلائق صفا. 
حتى إذا و افى الموقف أهل السماو ات السبع، و الأرضين السبع، كسيت الثمس حر عشر سنين، وأدنيت رؤوس الخلائق قاب قوس أو قوسين، و لا ظل لأحد إلا ظل رب العالمين، فمن بين مستظل بظل العرش، وبين مضحو بحر الثمس، قد صهرته بحرها، واثتت كربه وقلقه من وهجها، ثم ازدحمت الأمم وتدافعت، فدفع بعضهم بعضا، وتضايقت فاختلفت الأقدام، و انقطعت الأعناق من العطش، و اجتمع حر الثمس، ووهج أنفاس الخلائق، وتز احم أجسامهم، ففاض العرق سائلا حتى لهى استتقع على وجه الأرض، ثم على الأبدان، على قدر مراتبهم ومنازلهم عند الله عز وجل بالسعادة والثقاء، حتى إذا بلغ من بعضهم العرق كعبيه، وبعضهم حقويه، وبعضهم إلى شحمة أذنه، ومنهم من كاد أن يغيب في عرقه، ومن قد توسط العرق من دون ذللك منه.

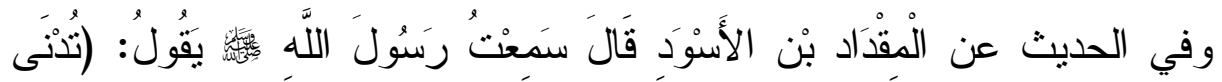

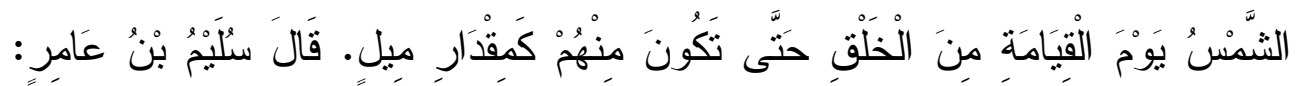

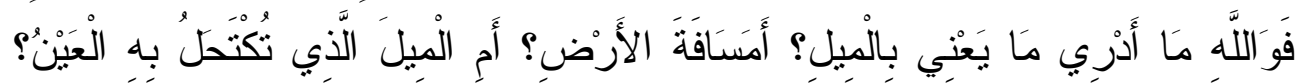

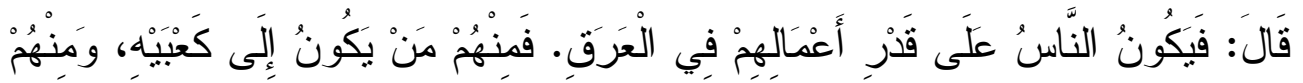

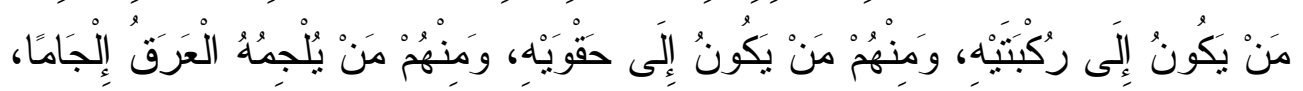

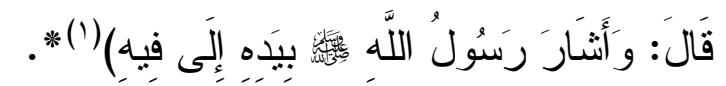

عن ابن عمر -رضي الله عنهما- قال: قال رسول الله مرة: إن الكافر ليقوم يوم القيامة في بحر رشحه إلى أنصاف أذنيه من طول

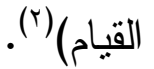

$$
\begin{aligned}
& \text { (1 (1) مسلم. كتاب الجنة ووصف نعيمها و أهلها. حديث رقم } 1 \text { ـ 101. }
\end{aligned}
$$

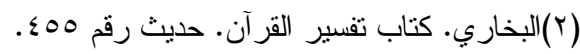


القيامة الكبرى (مشاهد ووقائع، دروس وعبر)

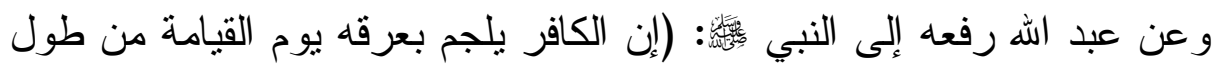

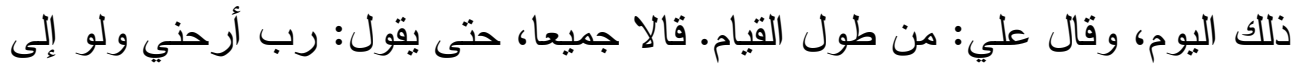

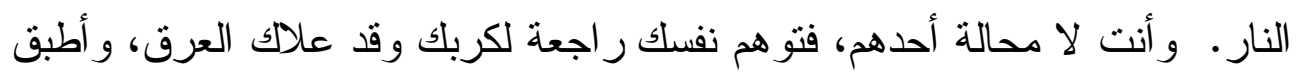

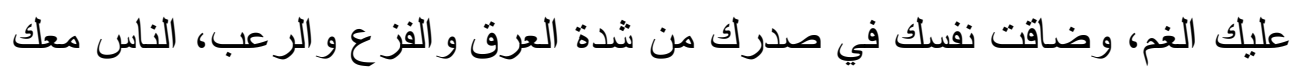

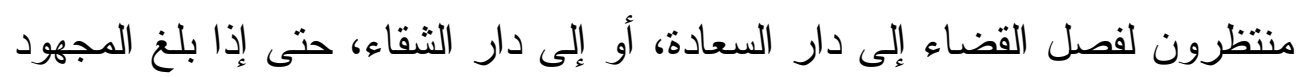
منك ومن الخلائق منتهاه، وطال وقوفهر لا يكلمون و لا ينظرون في أمور هم. عن قتادة أو كعب قال: يوم يقوم الناس لرب العالمين قال: يقومون مقدار

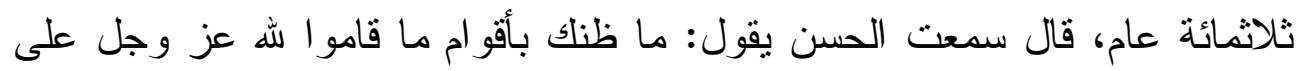

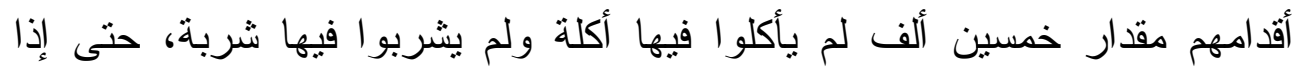

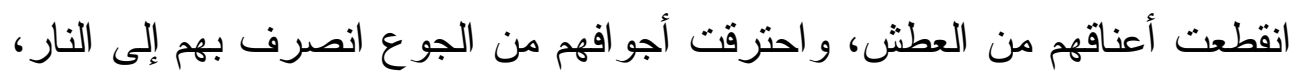

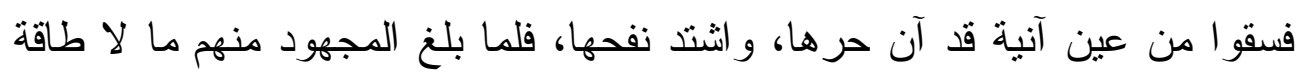

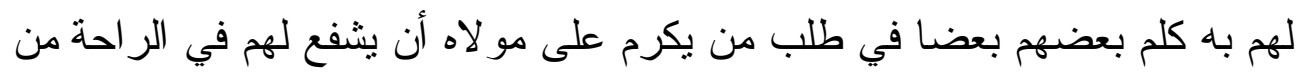

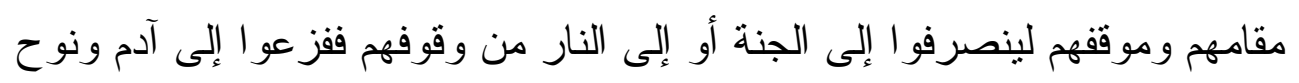

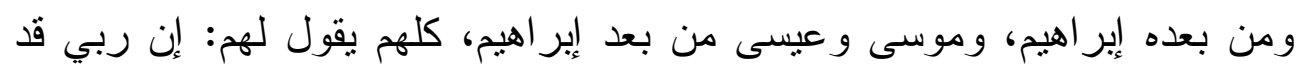

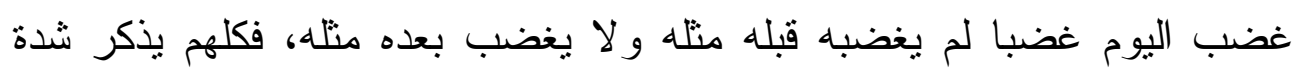

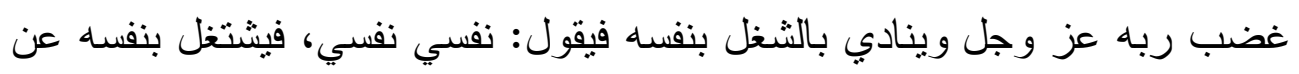

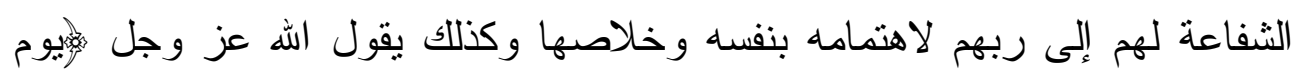

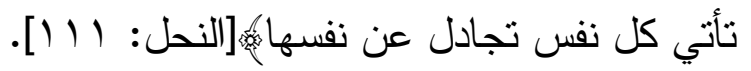

فتو هم أصوات الخلائق وهم ينادون بأجمعهم / منفرد كل واحد منهم بنفسه،

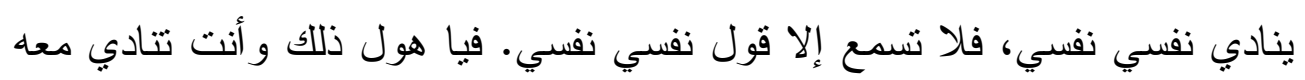
بالثغل بنفسك و الاهتمام بخلاصها من عذاب ربك و عقابه، فما ظنالك بيوم ينادي فيه المصطفى آدم و الخليل إبر اهيم، و الكليم موسى، و الروح ح و الكلمة عيسى مع كر امتهم 
على اله عز وجل و عظم قدر منازلهم عند الله عز وجل كل ينادي: نفسي نفسي، شفقا من شدة غضب ربه، فأين أنت منهم في إثنفاقك في ذلك اليوم، و اثتنغالك بذلك

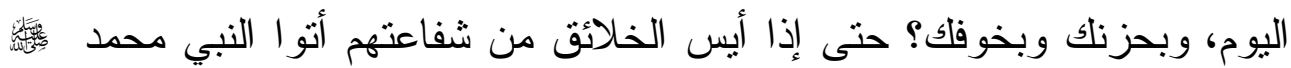

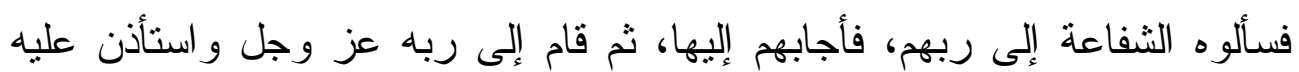
فأذن له، ثم خر لربه ساجدا، ثم فتح عليه من محامده و الثناء عليه لما هو أهله، إنهاء

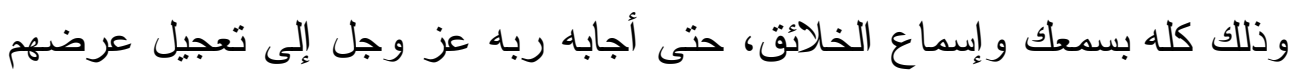
و النظر في أمورهم (').

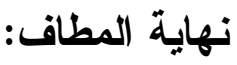

\section{يعالج هذا المبحث نقاط عدة}

- حشر الكافرين إلى جهنم

\section{-الصراطو أحوال العباد عند المرور عليه}

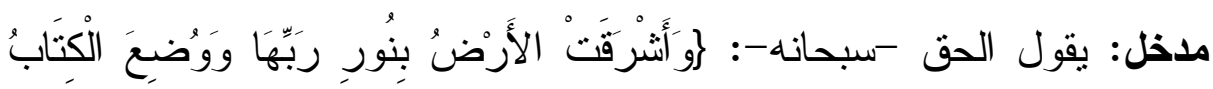

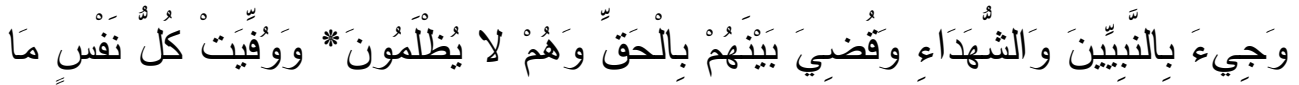

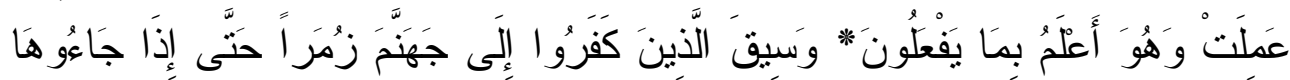

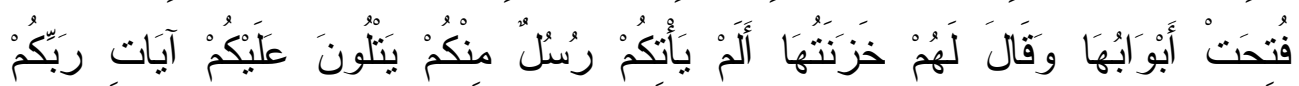

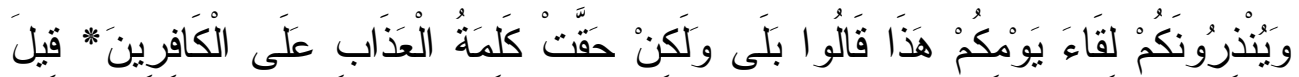

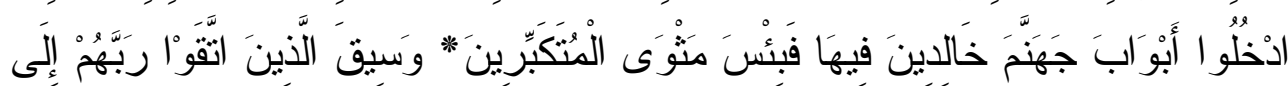

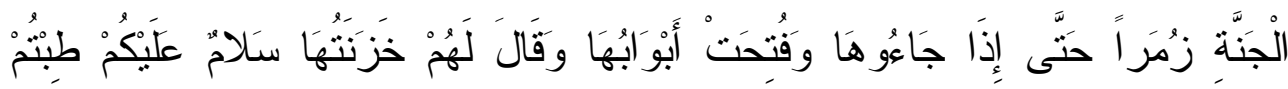

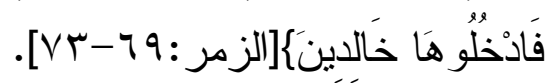

لقد صورت هذه الآيات بعبارة موجزة الكثير من مشاهد هذا اليوم وضع 
الكتاب وشهادة الثهود و الفصل و القضاء وحشر الكافرين إلى جهنم زمراً و المتقين

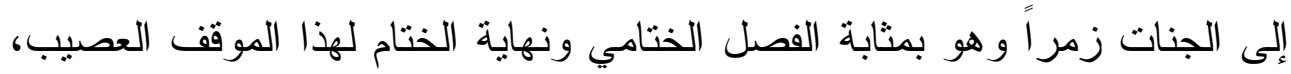
فبعد العرض و الحساب و الوزن و الميزان و الفصل و القضاء يكون الجزاء و الثو اب

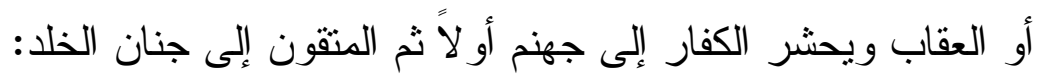

\section{حشر الكفار إلى جنهم ويئس القرار}

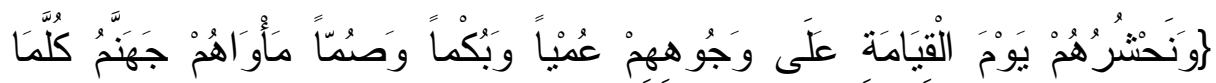

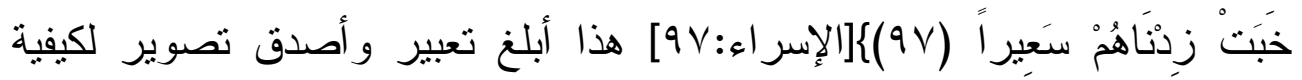

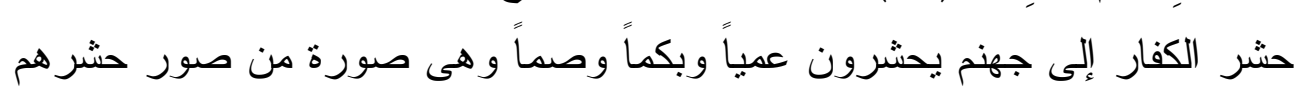
نزيدها توضيحاً وبياناً في الفقرة التالية:

لقد جاءت نصوص كثيرة تصور لنا كيف يكون حشر الكفار إلى النار هم و آلهتهم التي كانو ا يعبدونها:

ا - فمن ذلك أنهم يحشرون كقطعان المانشية جماعات جماعات، ينهرون نهر اً

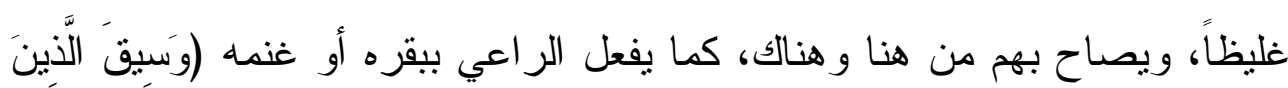

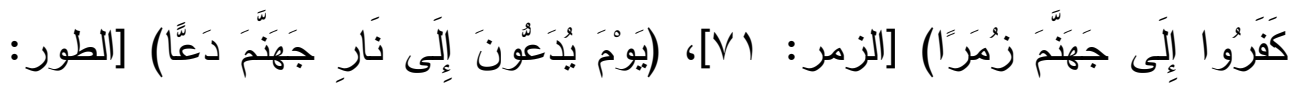

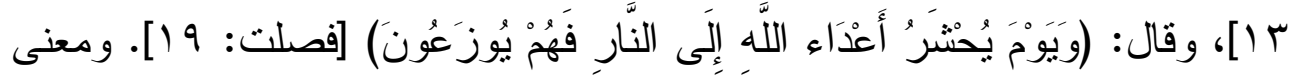
يوزعون أي يجمعون، تجمعهم الزبانية على آخرهم، كما يفعل البشر بالبهائم.وكما

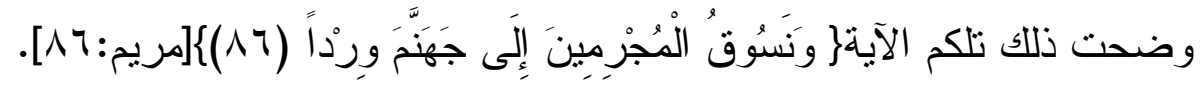
r- و أفادت النصوص أنهم يحشرون إلى النار على وجوههم، لا كما كانوا

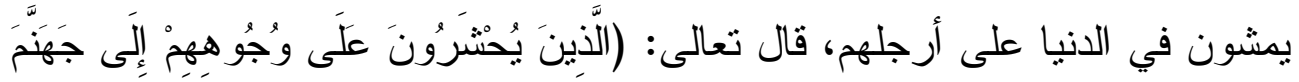

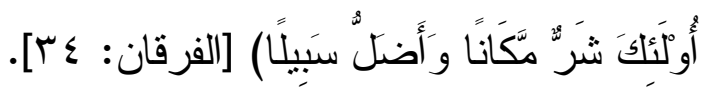

روى البخاري ومسلم عن أنس بن مالك أن رجلاً قال: يا رسول الله، كيف 
يحشر الكافر على وجهه يوم القيامة؟ قال: " أليس الذي أمثاه على رجليه في الدنيا

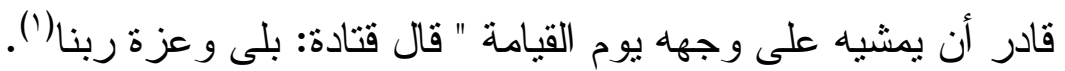

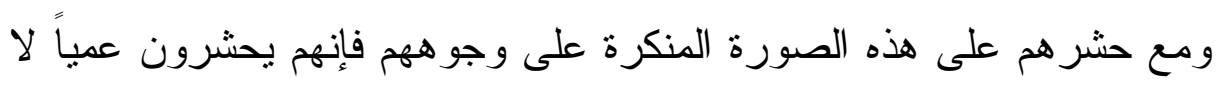

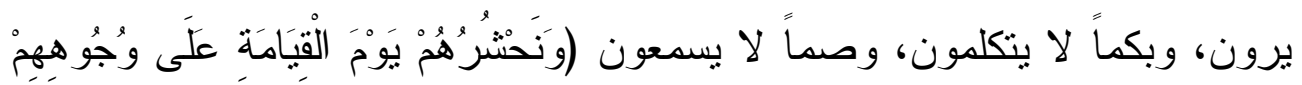

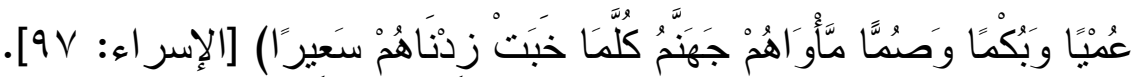

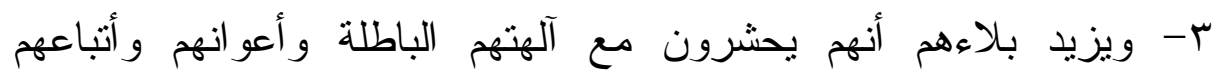

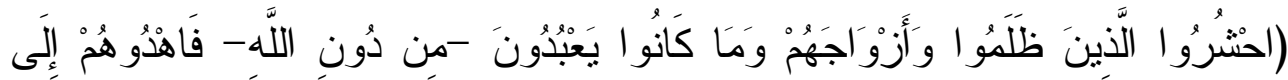

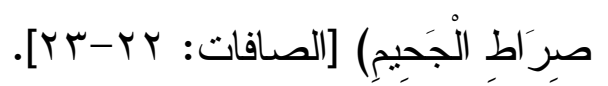

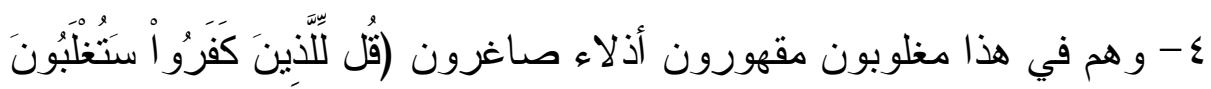

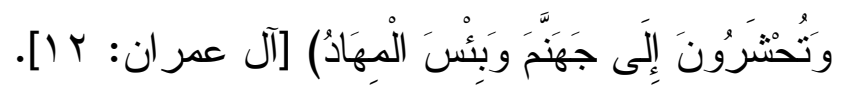

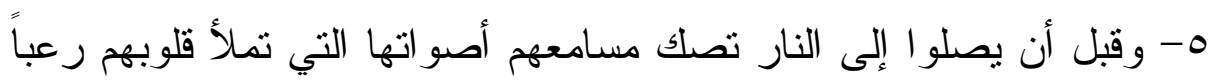

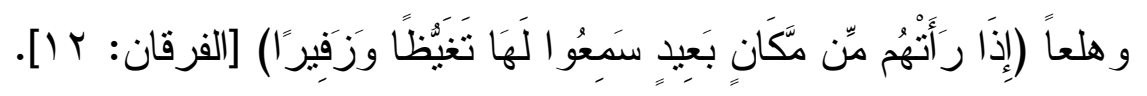

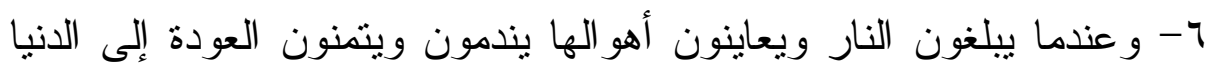

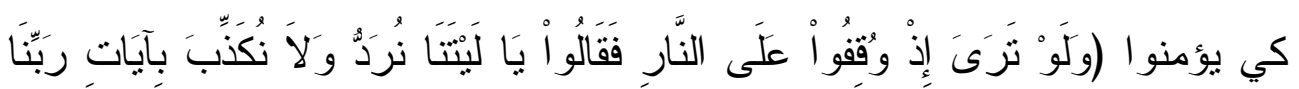

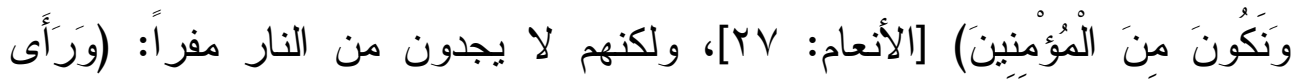

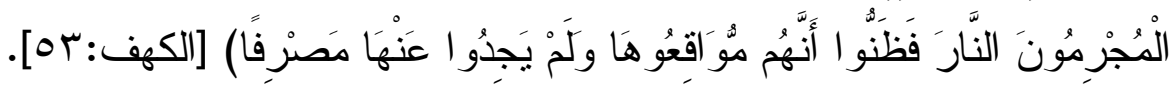
- و وعند ذلك يؤمرون بالاخول في النار وغضب الجبار أذلاء خاسرين

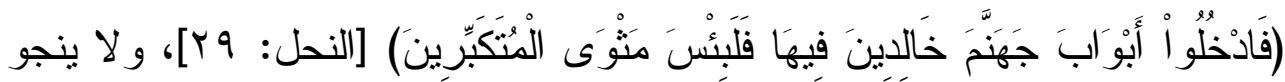

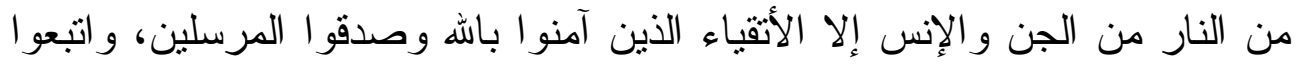




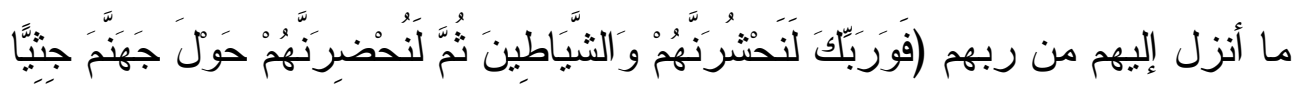

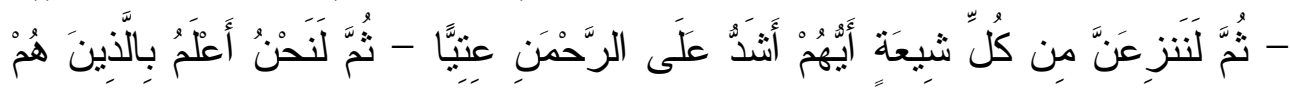

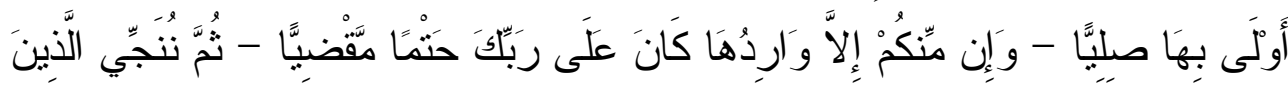

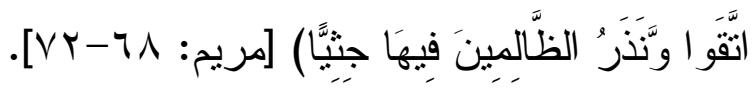

يقول سيد قطب رحمه الله تعالى في تقسير هذه الآيات: " يقسم الله بنفسه وهو

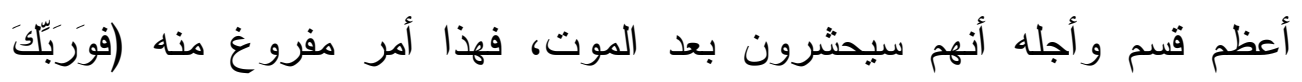

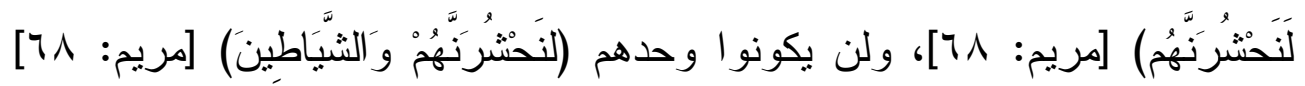

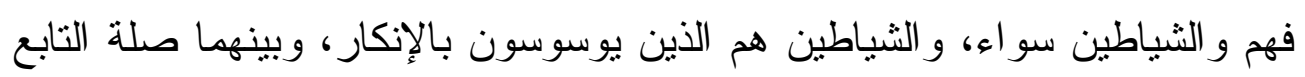
و المنبو ع، و القائد و المقود...

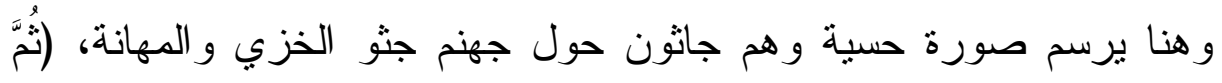

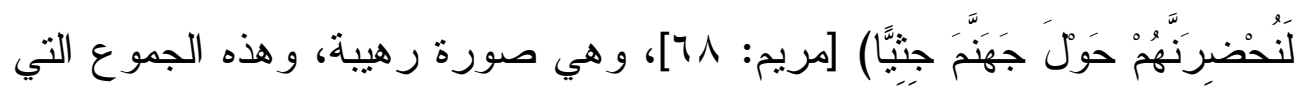

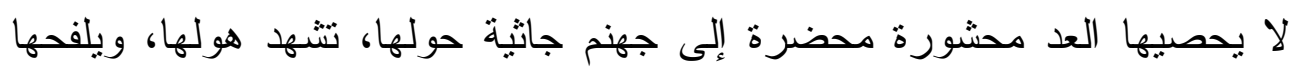

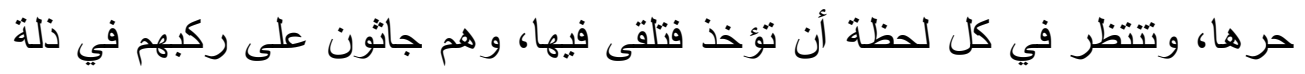

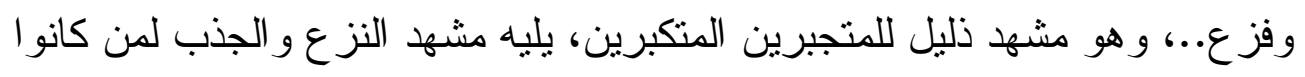

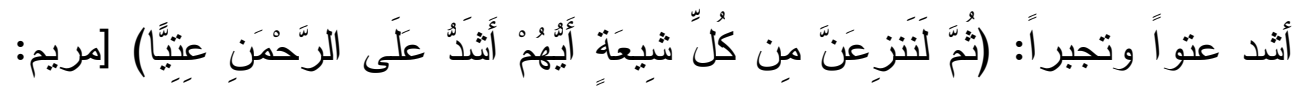

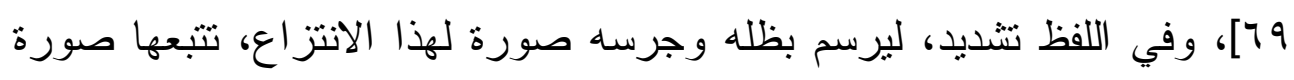

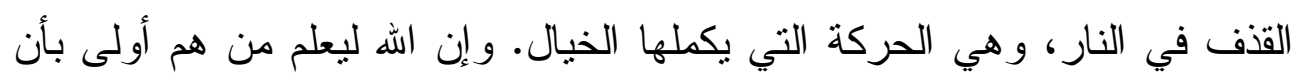

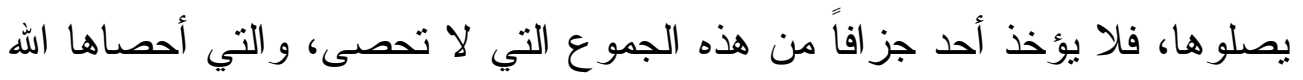

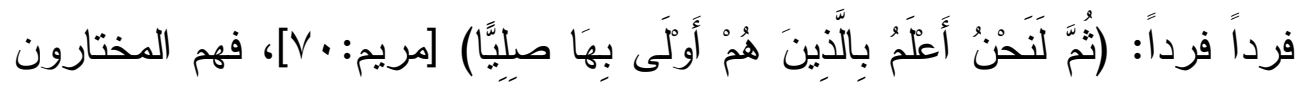

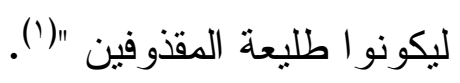

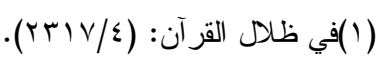


ومما لا شك فيه أن هذا الحشر قبل أن يضرب الصر اط وهذا ما وضحته لنا

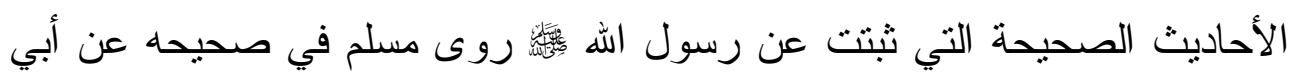
سعيد الخدري، عن النبي

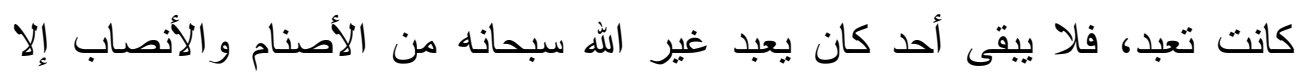

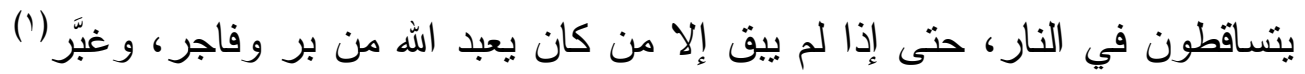

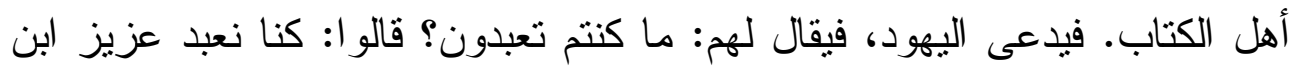

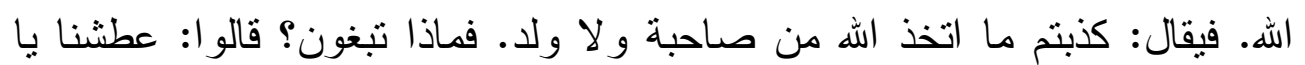

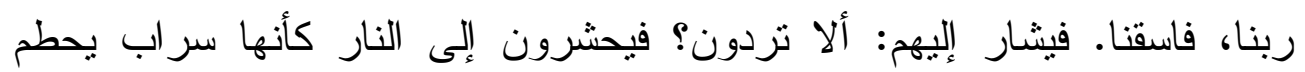
بعضها بعضاً، فيتساقطون في النار.

ثم يدعى النصارى، فيقال لهم: ما كنتم تعبدون؟ قالو ا: كنا نعبد المسيح ابن

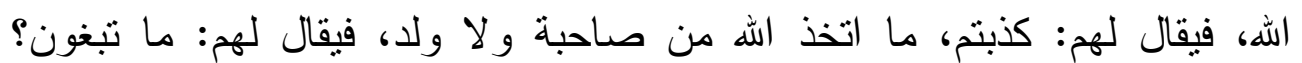

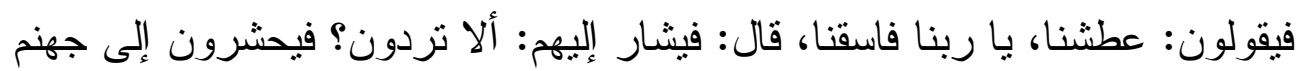

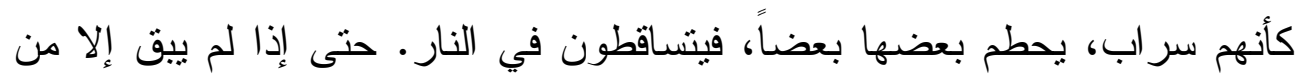

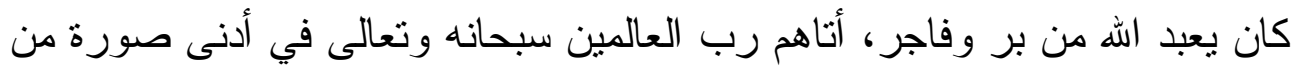

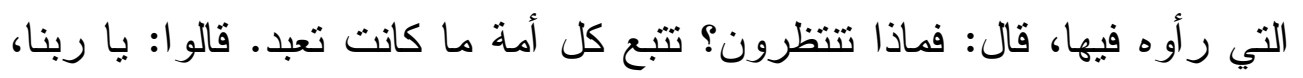

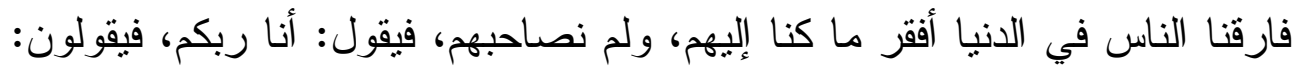

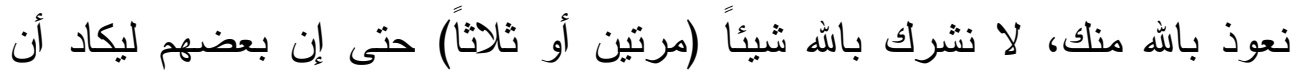
ينقلب. فيقول: هل بينكم وبينه آية فتعرفونه بها؟ فيقولون: نعم، فيكثف عن ساق، فلا ييقى من كان يسجد لله من تلقاء نفسه إلا أذن الله له بالسجود، و لا يبقى من كان ليان

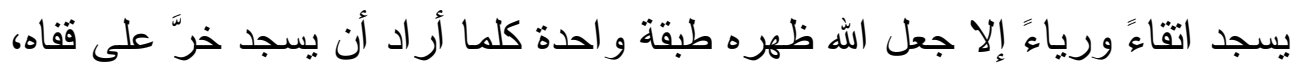


ثم يرفعون رؤوسهم، وقد تحول في صورته التي رأوه فيها أول مرة، فقال: أنا

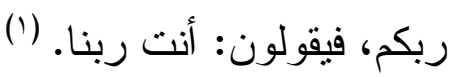

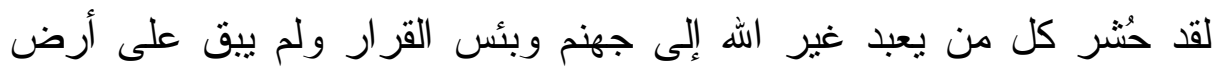

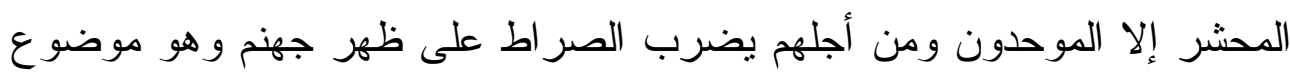

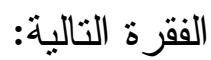

الصر اط: وفيه نقاط عدة: - ال

$$
\text { تعريف الصر اط }
$$

ما ورد فيه من آيات وأحاديث

\section{معتقد أهل السنة والفرق المختلفة في الصر لطاط:}

\section{تعريف الصراط وحقيقته:}

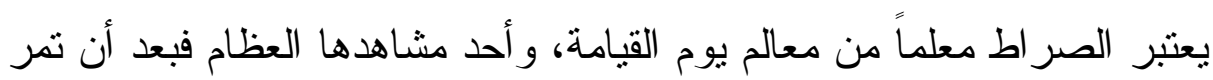
مو اقف الحساب بما فيها وبعد العرض و المبزان، وشهادة الثهود وتطاير الصحف.

$$
\text { وتمايز العباد إلى فريقين فريق في الجنة وفريق في السعير . }
$$

بعد ذللك كله يضرب الصر اط وينصب على ظهر اني جهنم كي يجتاز الناس

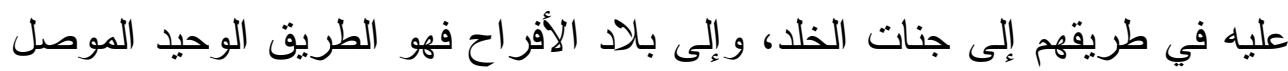

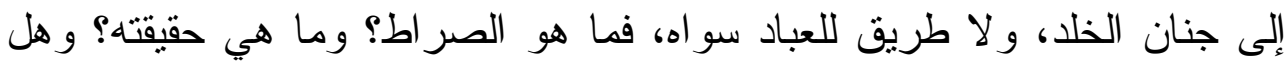
كل الناس تمر من فوق هذا الصراط؟ نساؤلات كثثرة نحاول الإجابة عنها في

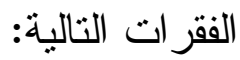

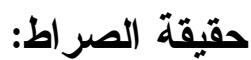

قال السفاريني: [الصر اط في اللغة الطريق الو اضح .ومنه قول جرير:

$$
\text { ( (1) }
$$


القيامة الكبرى (مشاهد ووقائع، دروس وعبر)

أمير المؤمنين على الصر اط***** إذا اعوج الموارد مستقيم

وفي الثرع: جسر ممدود على منن جهنم، يرده الأولون والآخرون، فهو

قنطرة تمر من فوق النار ليصل المؤمنون عن طريقها إلى الجنة].

الصر اط في ضوء الكتاب والسنة

لقد تضافرت آيات القرآن الكريم و الأحاديث الصحيحة على إثبات حقيقة هذا الصر اط، وبينت كيف يكون المرور عليه في يوم القبامة، فمن القرآن الكريم نجد

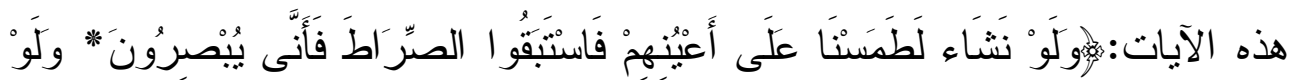

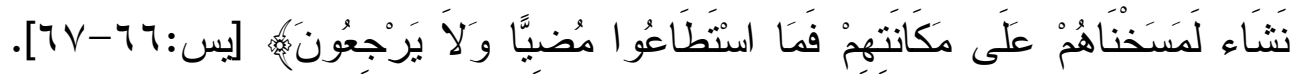
وفيها النص الصريح على إثبات حقيقته ووصف لحالة فريق من الناس عند محاولة العبور و المرور عليه.

- ونجد آيات من سورة الحديد وهي ترسم لنا صورة لقافلة الإيمان في المقدمة أثثاء لحظات العبور والاجتياز ومن خلفها قافلة النفاق وقد أغلق الطريق في

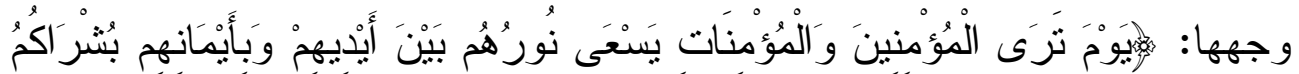

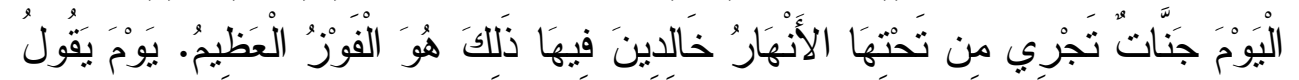

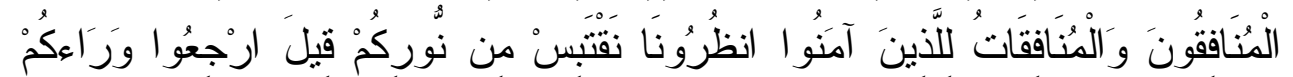

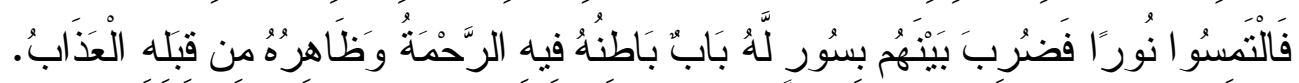

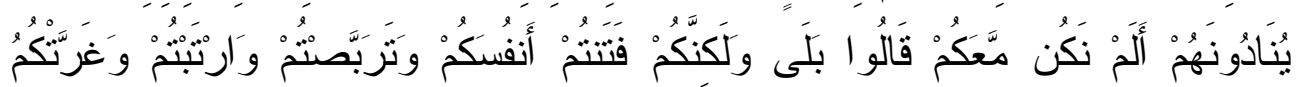

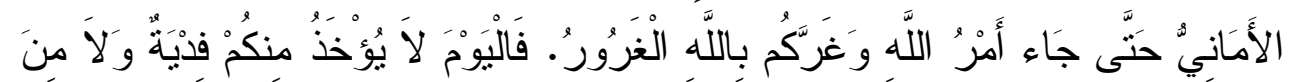

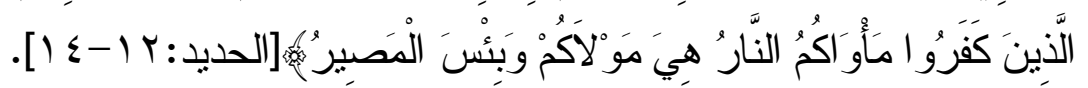

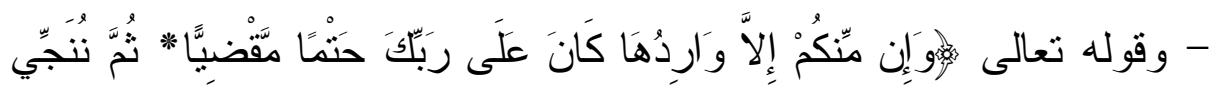

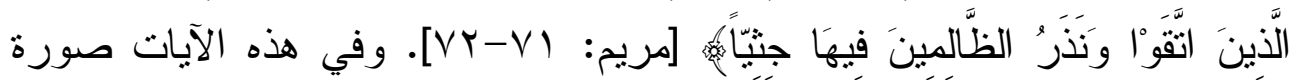
موجزة للمرور من على الصر اط، فهي تنين بأن الجميع واردها فالكفار قد دخلوها 
القيامة الكبرى (مشاهد ووقائع، دروس وعبر)

من قبل أما المؤمنون فقد مروا من فوق ظهرها ونجاهم الله منها. وما جاء مجملاً في كتاب الله سبحانه- جاء تفصيله وبيانه في أحاديث كثيرة

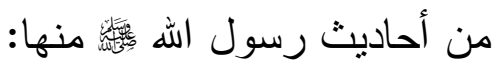

أروى مسلم في صحيحه عن أبي سعيد الخدري، عن النبي كان يوم القيامة أذن مؤذن: لتتبع كل أمة ما كانت تعبد، فلا ييقى أحد كان يعبد غير

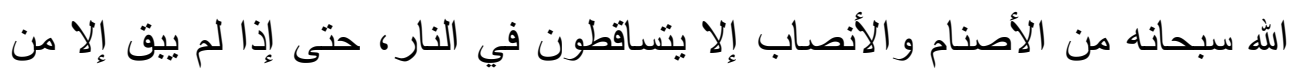

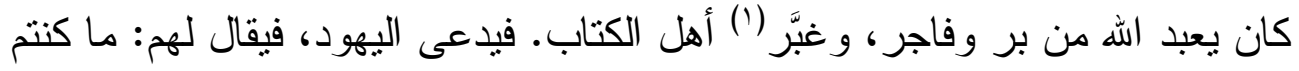
تعبدون؟ قالو ا: كنا نعبد عزيز ابن الله. فيقال: كذبتم ما اتخذ الله من صاحبة ولا

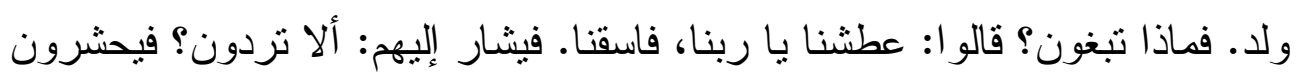
إلى النار كأنها سر اب يحطم بعضها بعضاً، فيتساقطون في النار .

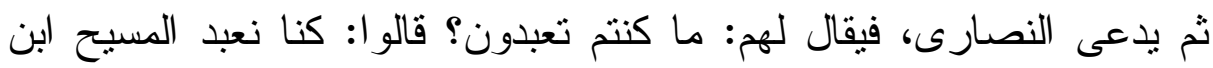

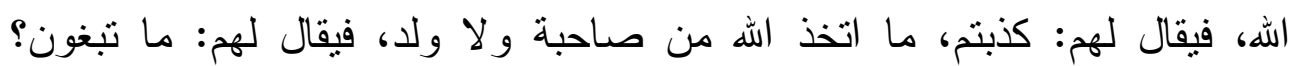

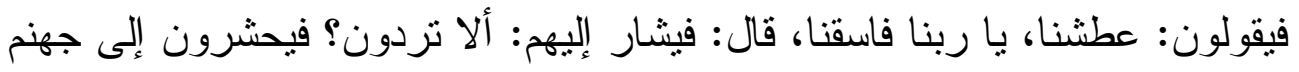

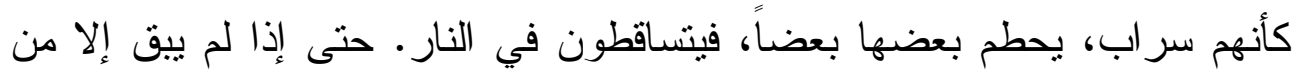

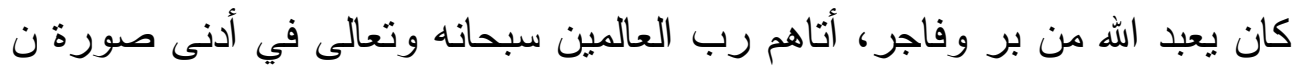

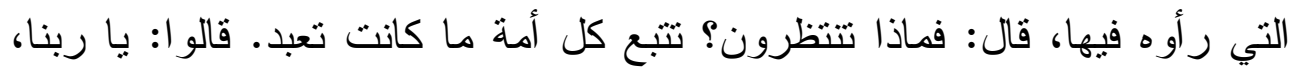

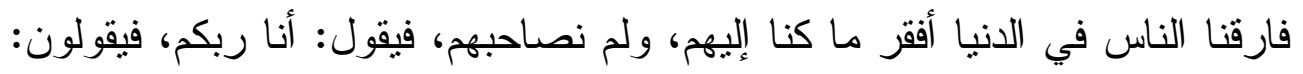

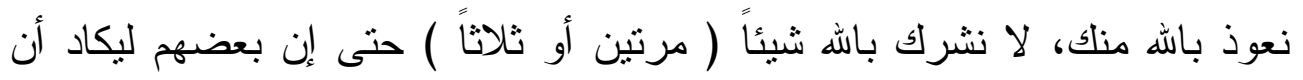

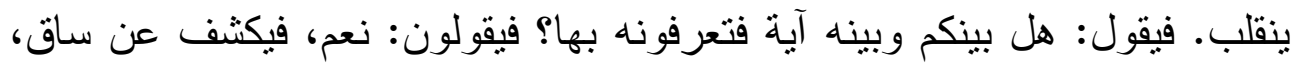
فلا يبقى من كان يسجد لله من تلقاء نفسه إلا أذن الهه له بالسجود، و لا ييقى من كان

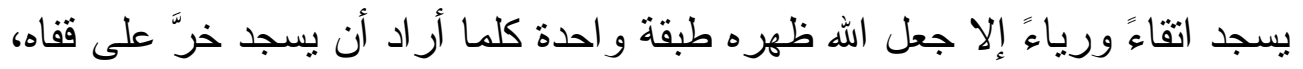


ثم يرفعون رؤوسهم، وقد تحول في صورته التي رأوه فيها أول مرة، فقال: أنا ربكم، فيقولون: أنت ربنا.ثم يضرب الجسر على جهنم، وتحل رلح الثفاعة، ويقولون:

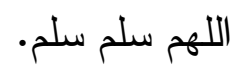

قيل: يا رسول الله، وما الجسر؟ قال: دحض مزلة، فيه خطاطيف وكلاليب وحسك، تكون بنجد فيها شويكة يقال لها: السعدان، فيمر المؤمنون كطرف العين، وكالبرق وكالريح وكالطير وكأجاويد الخيل و الركاب، فناج مسلم، ومخدوش مرسل، ومكدوس في نار جهنم"( ').

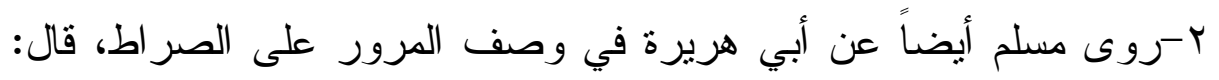

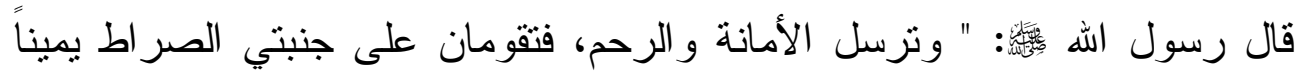

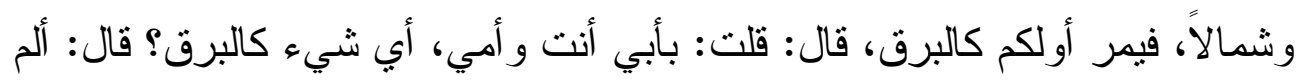

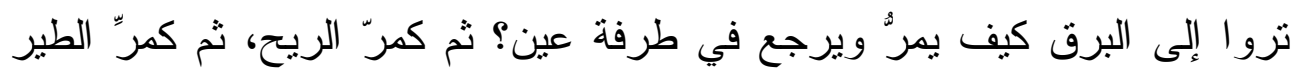

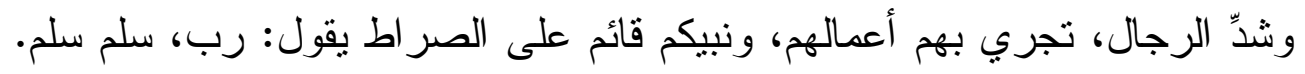
حتى تعجز أعمال العباد، حتى يجيء الرجل فلا يستطيع السير إلا زحفاً، قال:

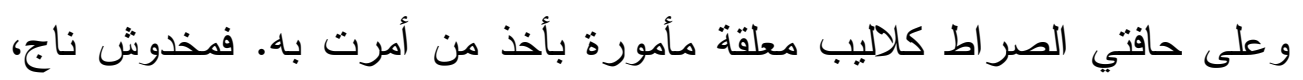

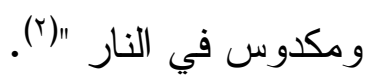

r-روى مسلم في صحيحه عن أبي الزبير، أنه سمع جابر بن عبد الله يسأل

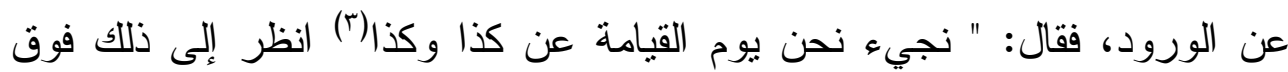

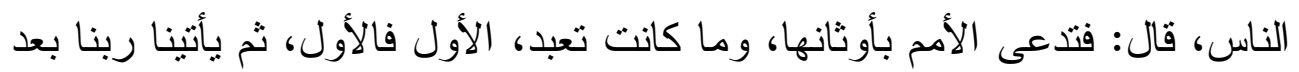

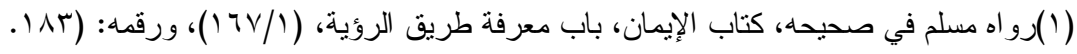

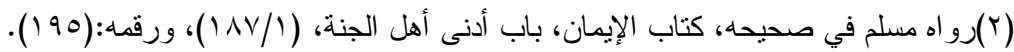

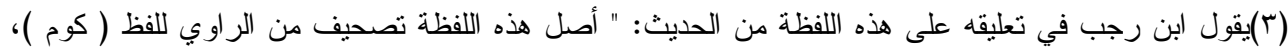

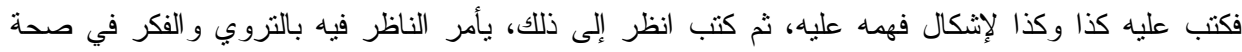

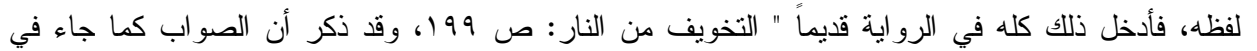

$$
\text { المسند وكتاب السنة: " نحن يوم القيامة على كوم فوق الناس، فنتعى الأمم بأوثانها.. ". }
$$


ذلك فيقول: من تتظرون؟ فيقولون: ننظر ربنا، فيقول: أنا ربكم، فيقولون: حتى

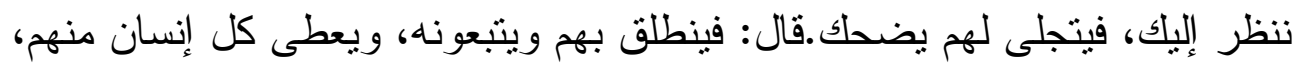
منافق أو مؤمن نور اً، ثم يتبعونه، و على جسر جهنم كلاليب وحسك، تأخذ من شاء

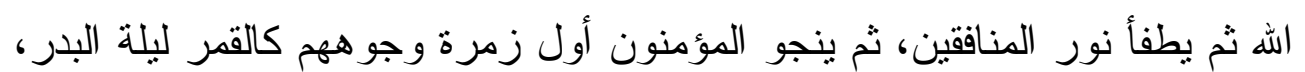

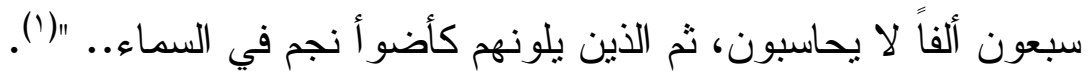

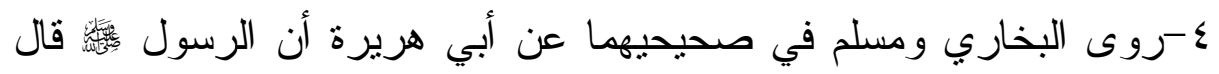

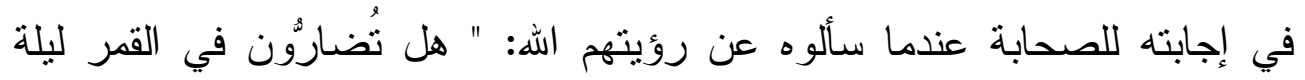
البدر ليس دونه سحاب؟ قالو ا: لا يا رسول الله.

قال فإنكم ترونه يوم القيامة كذلك، يجمع اله الناس، فيقول: من كان يعبد شيئًا

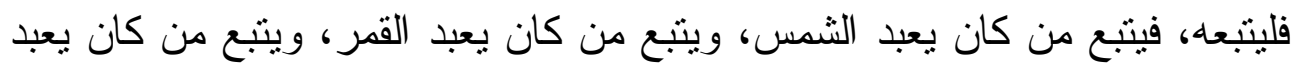

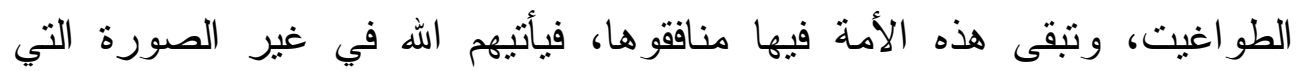

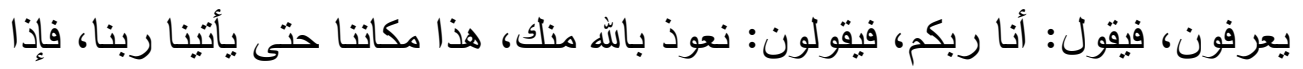

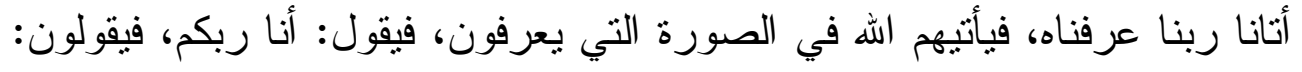

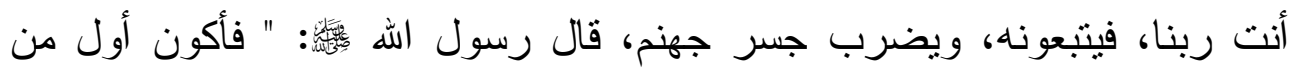
يجيز، ودعاء الرسل يومئذ: اللهم سلم سلم، وبه كلاليب متل شوك السعدان، أما رأيتم شوك السعدان؟ قالو ا: بلى يا رسول الله، قال: فإنها منل شوك السعدان، غير

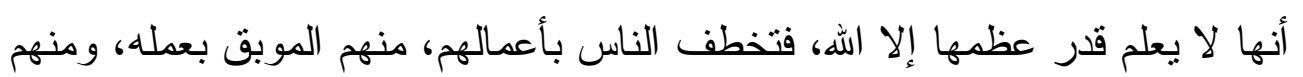

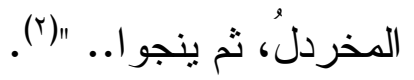

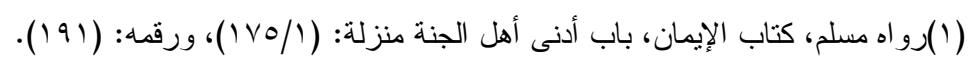

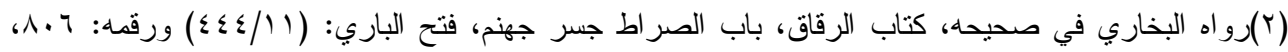

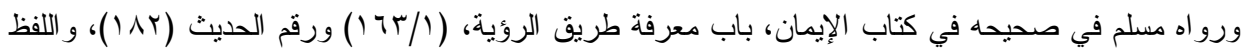

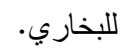


القيامة الكبرى (مشاهد ووقائع، دروس وعبر)

ه-وبوب عليه البخاري رحمه الله في كتاب الرقاق من صحيحه فقال: بابّ:

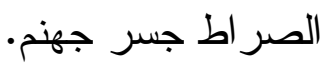

ד-وفي صحيح مسلم أيضاً عن أبي هريرة في وصف المرور على الصراط -

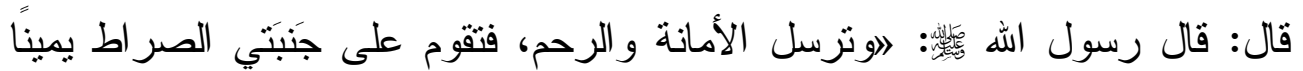

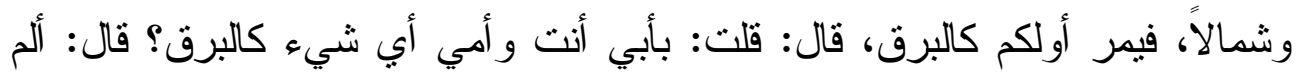

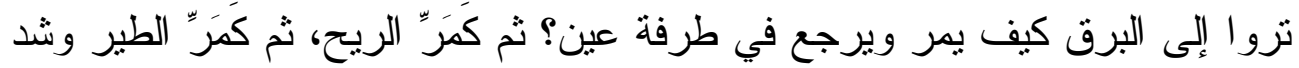

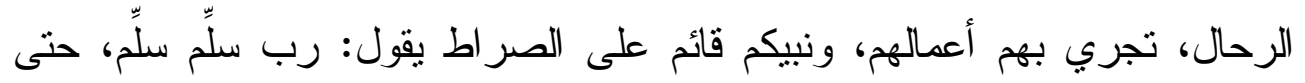

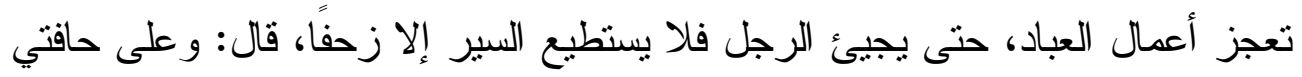

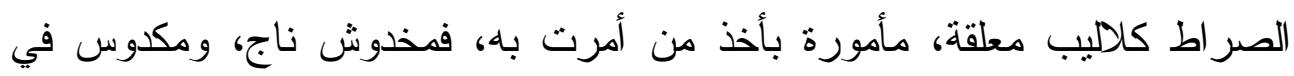
النار 《)

V- روى البيهقي بسنده عن مسروق، عن عبد الله، قال: " يجمع الله الناس يوم

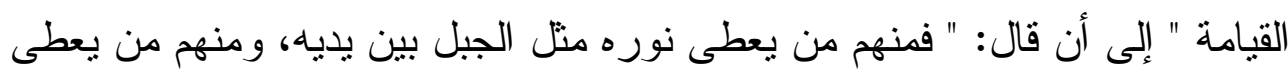

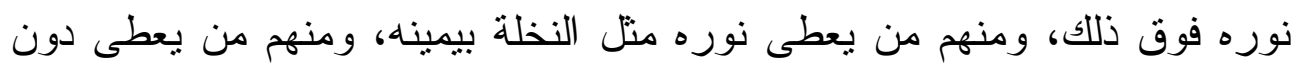

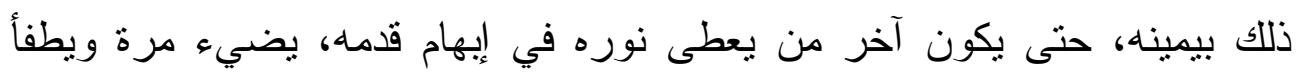

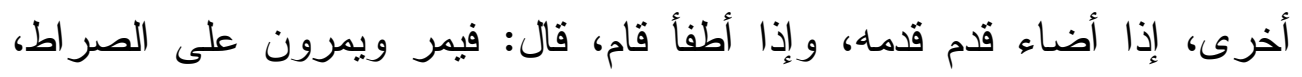

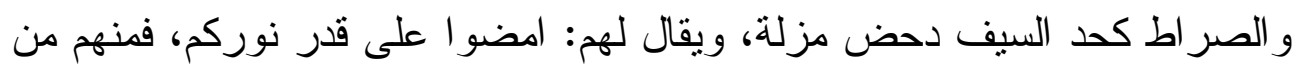
يمر كانقضاض الكوكب، ومنهم من يمر كالريح، ومنهم من يمر كالطرف، ومنهم

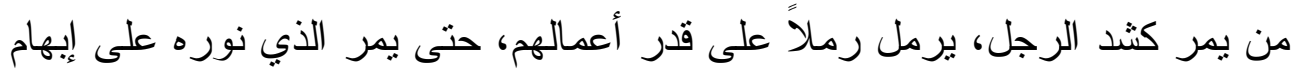

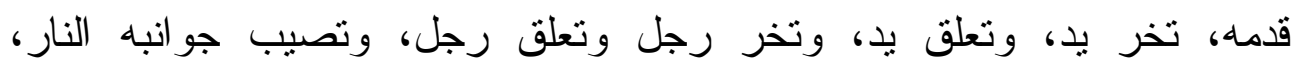

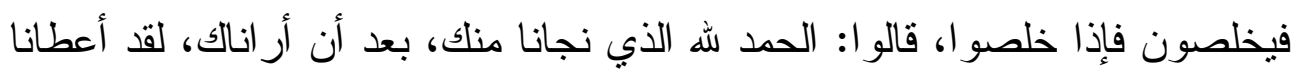


القيامة الكبرى (مشاهد ووقائع، دروس وعبر)

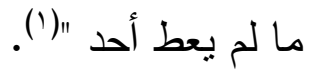

شدة الفزع عند المرور على الصراط:

و إن للمرور على الصر اط لهول وكرب وشدة لا يعلم مقدار ها إلا اله تعسالى

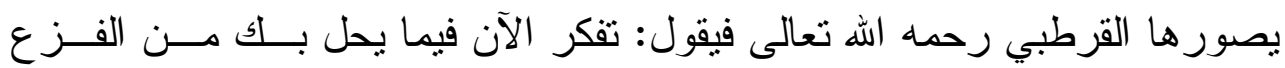

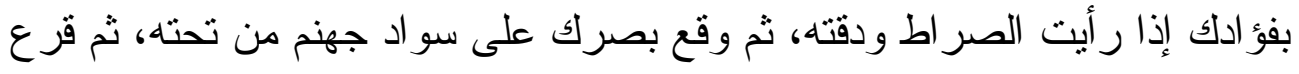

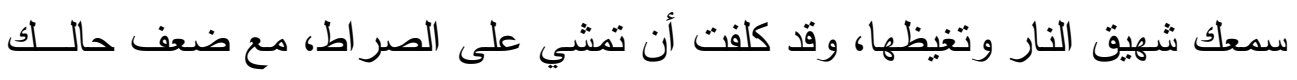

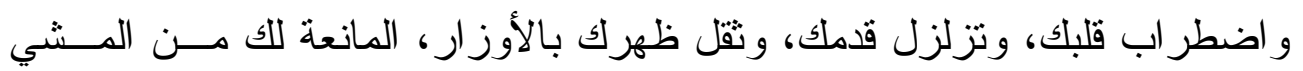

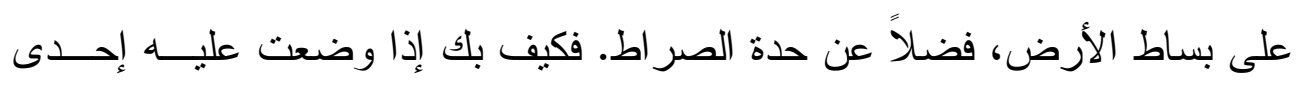

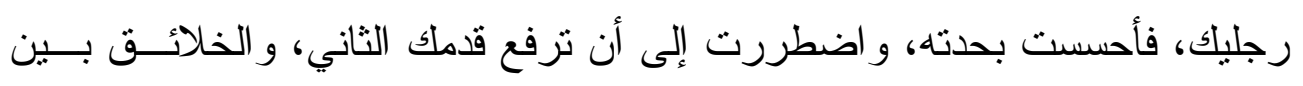

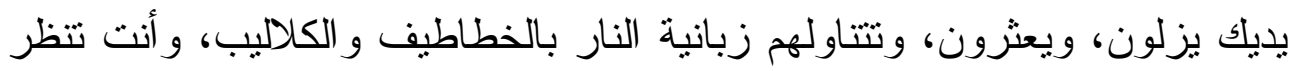

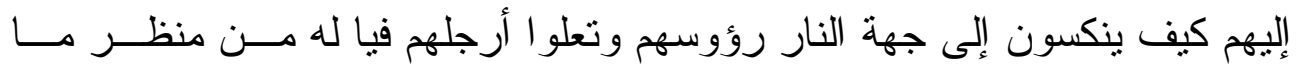

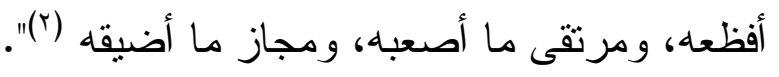

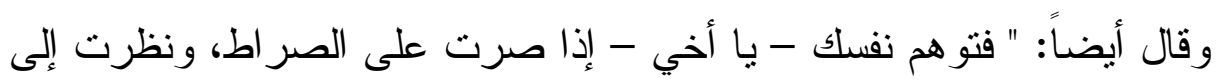

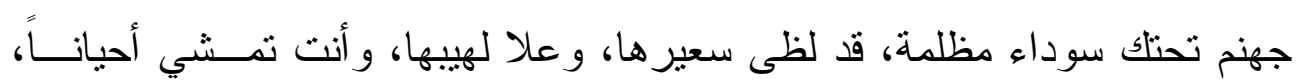

$$
\text { وتزحف أخرى. }
$$

وقد دلت هذه النصوص الصحيحة الصريحة الواضحة على عدة أمور مهمة

- أن حشر الكفار إلى النار بعد انتهاء العرض و الحساب والوزن و الميزان

( ()قال الثيخ ناصر في تخريجه لأحاديث شرح الطحاوية: (•v\&): ( صحيح، وأخرجه الحاكم، و أظن أن البيهقي

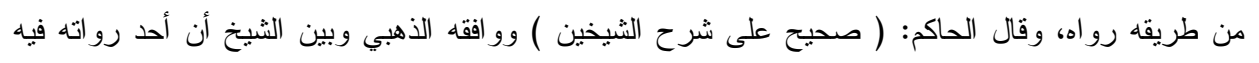

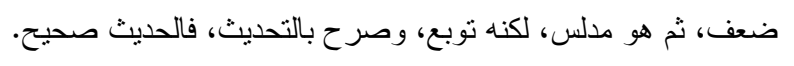

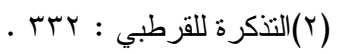


القيامة الكبرى (مشاهد ووقائع، دروس وعبر)

يحشر الكفار إلى جهنم على وجوههم عمياً وبكماً وصماً، ومعنى ذلك أنهم لا يمرون على الصر اط أو يحشرون إلى جهنم من خلاله.

- أن الصراط عبارة عن جسر وطريق للعبور من فوق جنم لا يصل أهل الجنة إليها إلا من خلا هذا الجسر، ولا طريق يوصل إلى الجنة من أرض

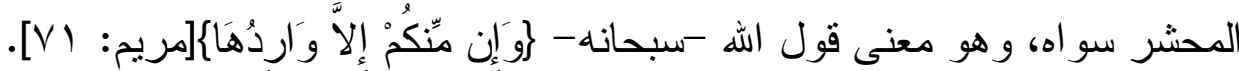
- أن اجتباز هذا الجسر و المرور و العبور عليه ليس بالأمر الهين، فهو أدق من الثعرة، وأحد من السيف، وعلى جو انبه كلاليب معلقة منل الأشو الك، تتخطف من أمرت بخطفه الناس من فوق هذا الجسر، لتلقي بهم في قاع جهنم، ومن الناس من تجرحه وتصيبه وينجو فلا يهوي إلى القاع، ومنهم من يكس وينكس على هنى رأسه

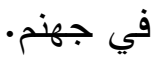

- اجتمع مع دقة هذا الطريق وضيقه وحدته الظلمة الثديدة. تلك التي أثنار إليها الحديث (هم في الظلمة دون الجسر)('فيتغد الله عباده المؤمنين بسابغ فضله

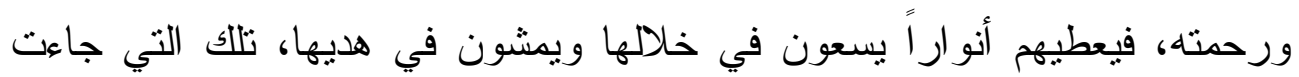

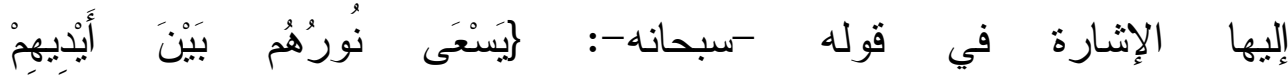

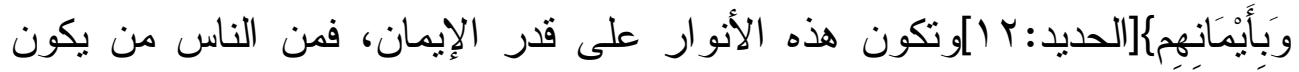
نوره كنور الثمس أو نور القمر أو ما دون ذلك حتى يكون آخر هم من يُعطى نوراً

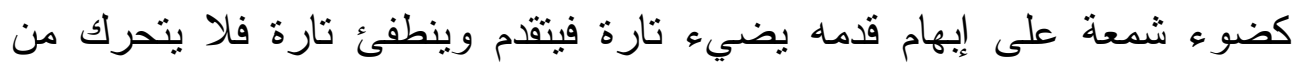
موضعه. - النجاة من المخاطر فوق هذا الصر اط على قدر الإيمان و الصلاح و التقوى

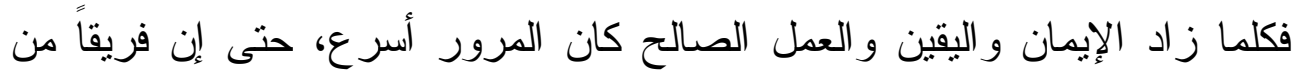


القيامة الكبرى (مشاهد ووقائع، دروس وعبر)

المؤمنين يمر بسرعة الضوء وتتناقص السرعة بنقص الإيمان فمنهم من يمر

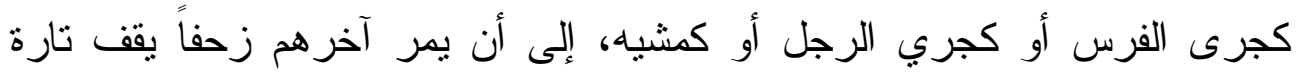

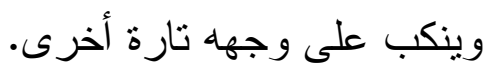

-حرص الأنبياء على نجاة أممهم وهم ويمرون في هذا الطريق الخطر حتى هذى إنهم يققون على جنبات هذا الطريق وعلى رأسهم النبي الموقف اللهم سلم سلم (').

- إذا كان حشر الكفار و المشركين إلى جهم قبل أن يضرب الجسر على ظهراني جهن، فإن حشر المنافقين إلى النار بعد أن يضرب هذا الجسر فهم

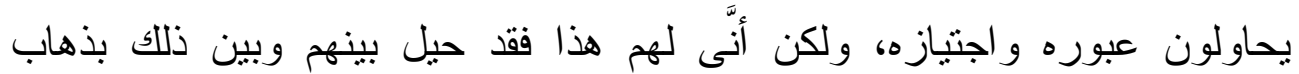
نورهم وتركهم في ظلمات لا ييصرون، فلما حاولوا أن يلحقو بقافلة المؤمنين ليقتبسو ا من ضوء نورهم ما يمكنهم من المرور ضُرب بينهم بسور له باب كان

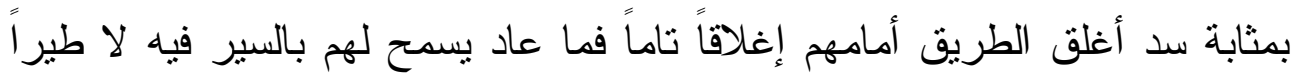

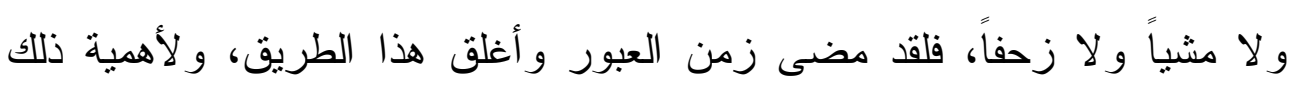
خصصنا له فقرة خاصة تحت عنو ان:

\section{فضرب بينهم بسور لله باب.}

كقيل ارجعوا ور اءكم فالتمسو ا نور أ\{ هذا هو حال المنافقين، وذلك بعد حشر الكفار إلى جهنم، فما بقي في عرصات القيامة إلا أتباع الرسل من الموحدين، وفيهر

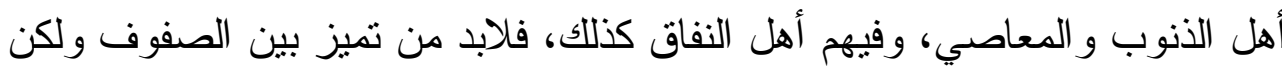

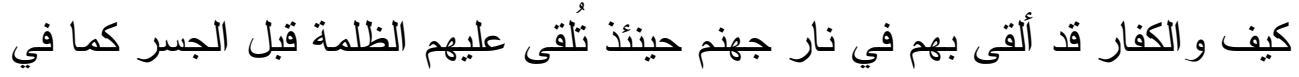

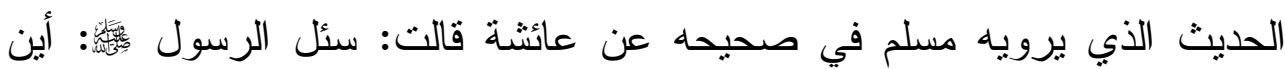


يكون الناس يوم تبدل الأرض غير الأرض و السماو ات؟ فقال: " هم في الظلمة دون

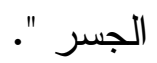

إن هذه الظلمة. التي غشيتهم قد غطت على كل شيء وهم يستبقون إلى الصر اط وهو دحضة مزلة و أدق من الثعرة وأحد من السيف فكيف العبور عليه

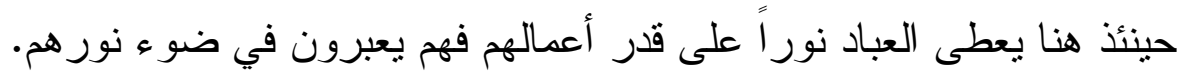

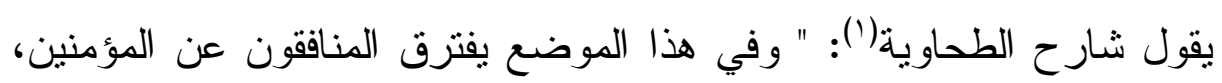
ويتخلفون عنهم، ويسبقهم المؤمنون، ويحال بينهم بسور يمنعهم من الوصول إليهم". وقد حدثنا الحق تبارك وتعالى عن مشهد مرور المؤمنين على الصر اط، فقال:

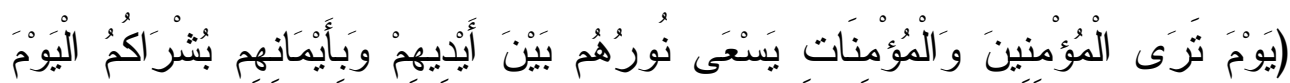

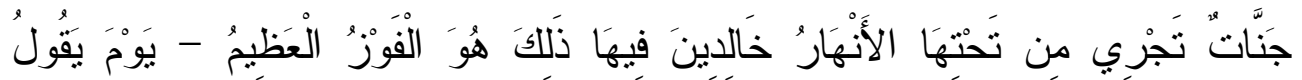

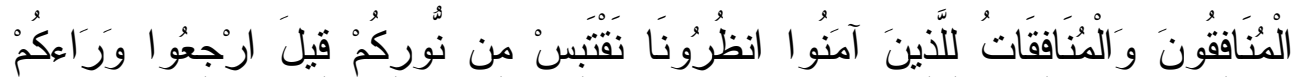

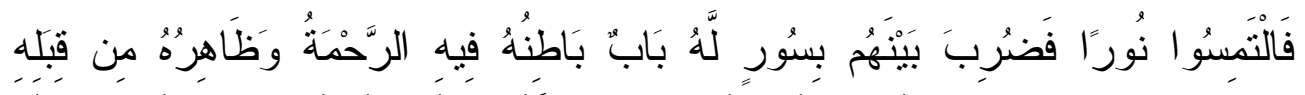

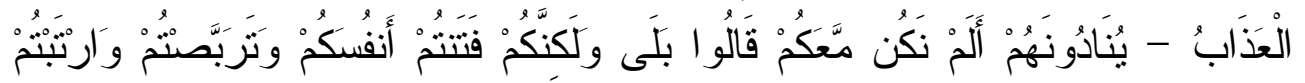

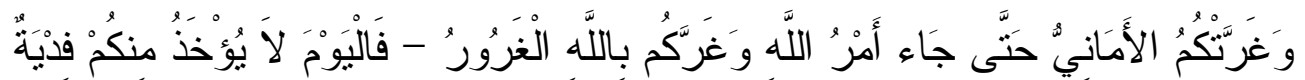

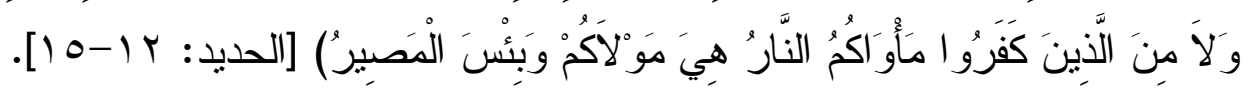
فالحق يخبر أن المؤمنين و المؤمنات الذين استتاروا بهذا الدين العظيم في

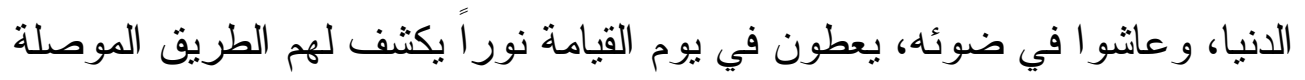

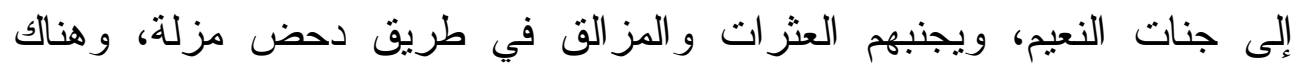

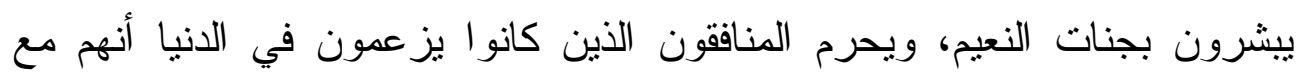

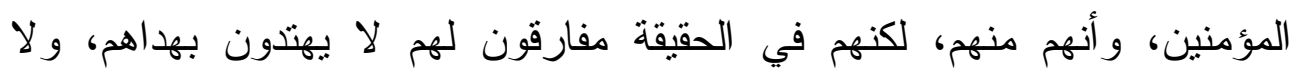

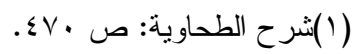


القيامة الكبرى (مشاهد ووقائع، دروس وعبر)

يسلكون سبيلهم من النور، كما حرموا أنفسهم في الدنيا من نور القرآن العظيه،

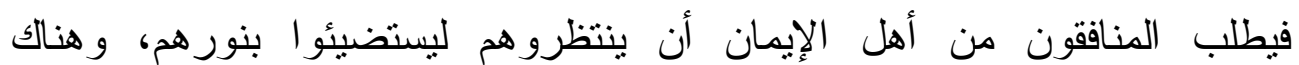
يخدعون، كما كانو ا يخدعون المؤمنين في الدنبا، ويقال لهم: ارجعوا وراءكم فالتمسو انور اً، وبذلك يعود المنافقون إلى الور اء، ويثقدم المؤمنون إلى الأمام، فإذإ تمايز الفريقان، ضرب الله بينهم بسور لله باب باطنه فيه الرحمة وظاهره من قبله العذاب، ويكون مصير المؤمنين و المؤمنات الجنة، ومصير المنافقين و المنافقات

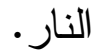

وقد أخبر الحق أن دعاء المؤمنين عندما يسعى نورهم بين أيديهم وبأيمانهم هو

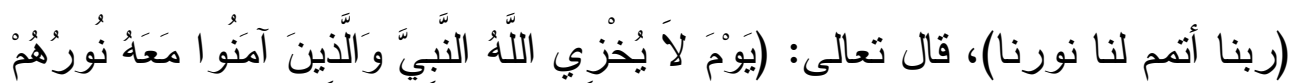

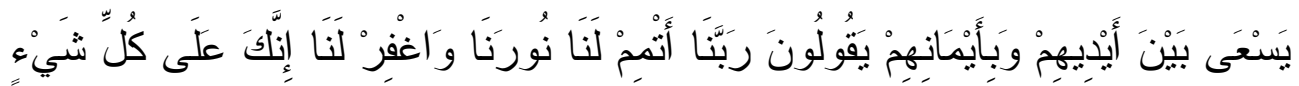

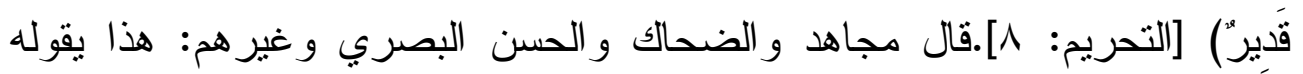
المؤمنون حين يرون يوم القيامة نور المنافقين قد طُفئ "((). ويصف صاحب الظلد هذا الموقف فيقول: و المشهد هنا بإجماله وتفصيله جديد بين المشاهد القر آنية، وهو من المشاهد التي يحييها الحوار، بعد أن ترسم صورتها المتحركة رسماً قوياً.

فنحن الذين نقرأ القرآن اللحظة نشهي مشهاً عجيباً. هؤلاء هم المؤمنون

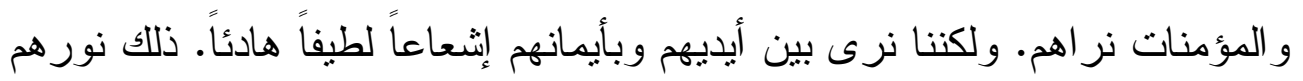

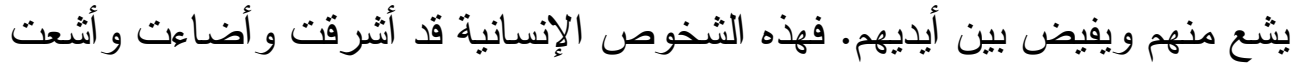

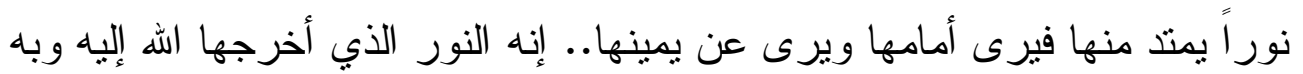

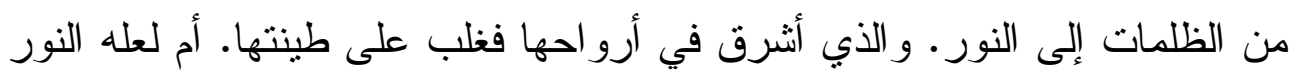


القيامة الكبرى (مشاهد ووقائع، دروس وعبر)

الذي خلق الله منه هذا الكون وما فيه ومن فيه، ظهر بحقبقته في هذه المجموعة

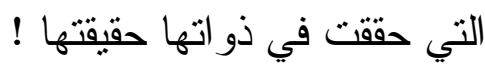

ثم ها نحن أولاء نسمع ما يوجه إلى المؤمنين و المؤمنات من تكريم وتبشير

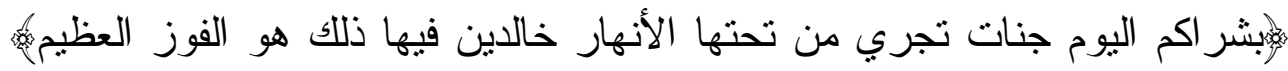
ولكن المشهد لا ينتهي عند هذا المنظر الطريف.. إن هنالك المنافقين و المنافقات في

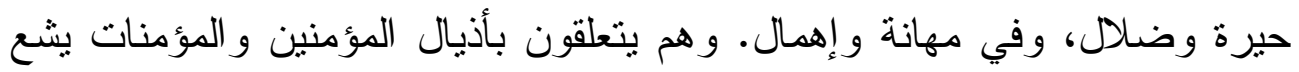

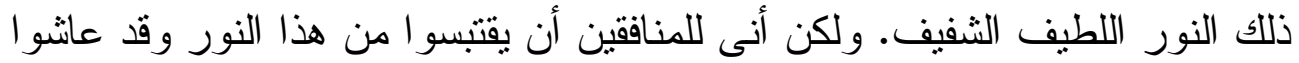

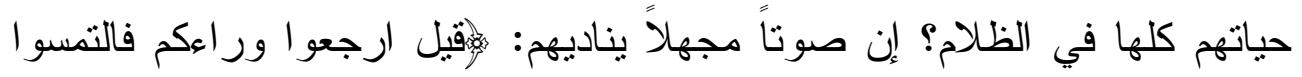

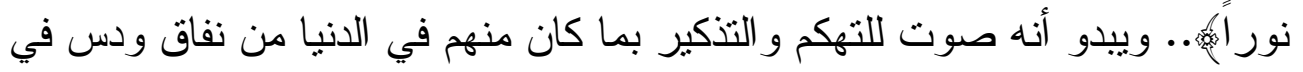

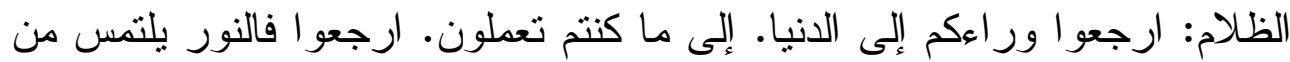

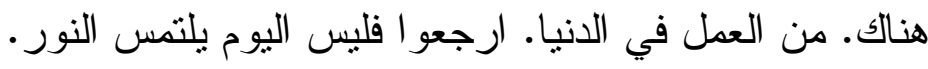
و على الفور يفصل بين المؤمنين و المؤمنات و المنافقين والمنافقات. فهذا يوم

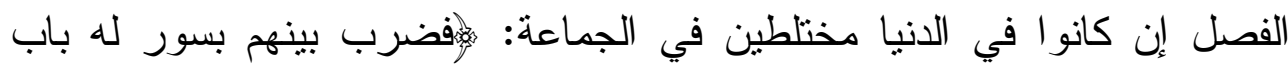

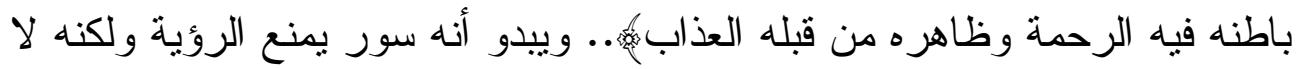

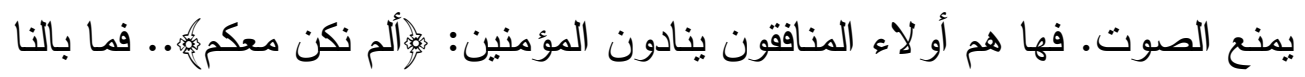

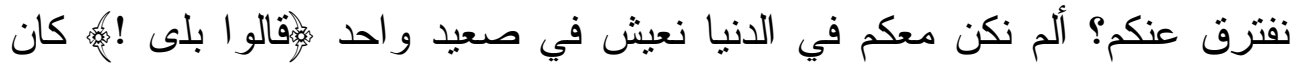

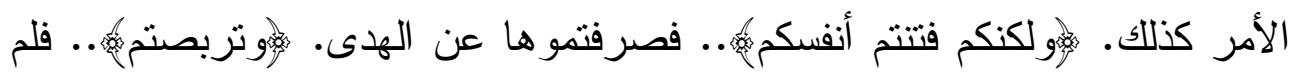

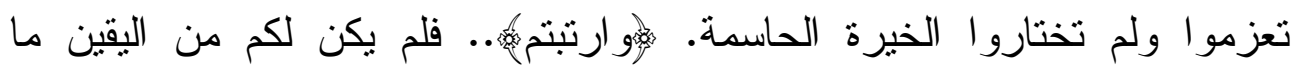

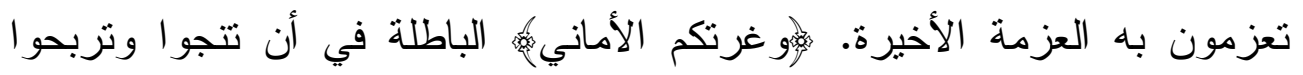

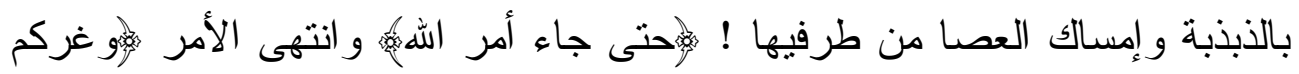


القيامة الكبرى (مشاهد ووقائع، دروس وعبر)

بالله الغرور مُ... وهو الثنيطان الذي كان يطمعم ويمنيكم.(')

من تتمة هذا المبحث: بيان معتقد أهل السنة والفرق المختلفة في الصر لط:

بين شارح الطحاوية معتقده في الصراط الدذكور في الأحاديث فقال: ونؤمن بالصر اط وهو جسر على جهنم إذا انتهى الناس بعد مفارقتهم الموقف إلى الظلمة

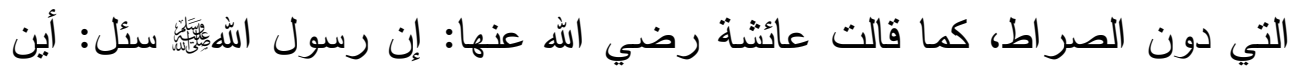
الناس يوم تبدل الأرض غير الأرض والسماوات؟ فقال: (هم في الظلمة دون النهان

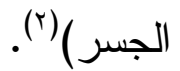

وقد بين السفاريني رحمه الله تعالى موقف الفرق من الصر اطو وهل هو صر اط مجازي أم حقيقي؟ فقال: اتفقت الكلمة بالجملة على إثبات الصر اط في الجملة، لكن الهن أهل الحق يثبتونه على ظاهره، من كونه جسر ا ممدودا على متن جهنم، أحد من إنى السيف و أدق من الثعر . الثل

و أنكر هذا الظاهر القاضي عبدالجبار المعتزلي، وكثثر من أتباعه زعماً منهم أنه لا يمكن عبوره و إن أمكن ففيه تعذيب، و لا عذاب على المؤمنين و الصلحاء يوم

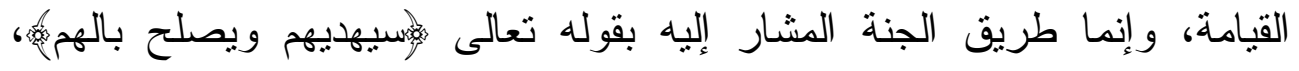

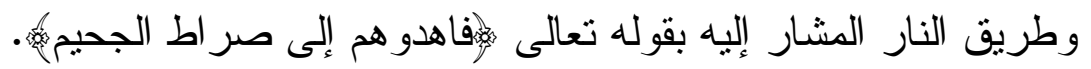

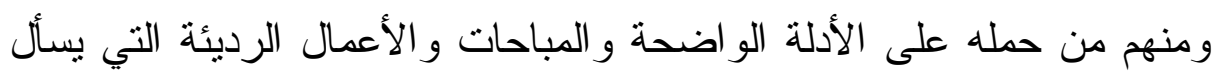
عنها ويؤاخذ بها، وكل هذا باطل وخر افات لوجوب حمل النصوص على على حقائقها،

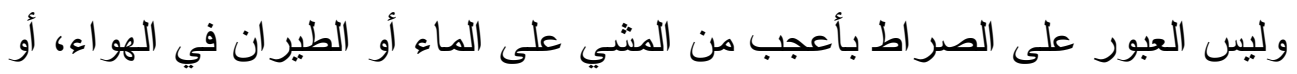

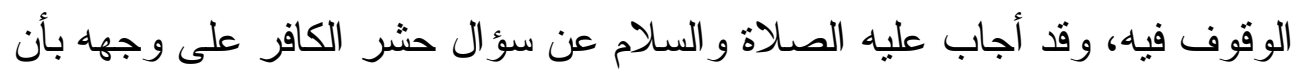

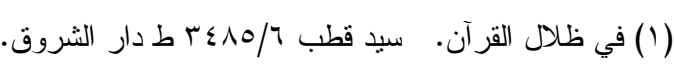

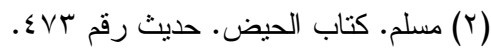

$$
\begin{aligned}
& -1 \vee \Lambda-
\end{aligned}
$$


القيامة الكبرى (مشاهد ووقائع، دروس وعبر)

القدرة صالحة لذلك. و أنكر العلامة القرافي كون الصر اط أدق من الثعر وأحد من السيف، وسبقه إلى ذلك شيخه العز بن عبد السلام.

و الحق أن الصراط وردت به الأخبار الصحيحة، وهو محمول على ظاهره بغير تأويل كما ثبت في الصحيحين و المسانيد و السنن و الصحاح، مما لا يحصى إلا فران بكلفة من أنه جسر مضروب على منت جهنم يمر عليه جميع الخلائق، وهم في

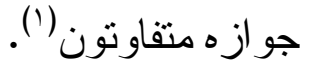

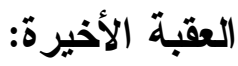

تزى هل كان اجتباز الصراط هو العقبة الأخيرة في طريق المؤمنين إلى

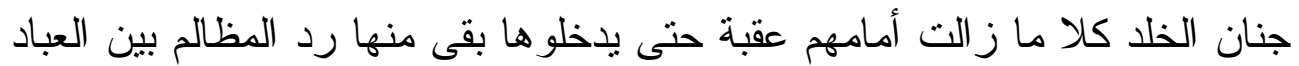
ولذلك فتر اهم يحبسون على قنطرة بين الجنة والنار بحث أهل العلم هذه المسألة ضمن حديثهم عن القنطرة التي يوقف عليها المسلمون قبل دخولهم الجنة (؟). و القنطرة في اللغة: الجسر (r)، وهي موضع يوقف فيه المؤمنون الذين جاوزوا

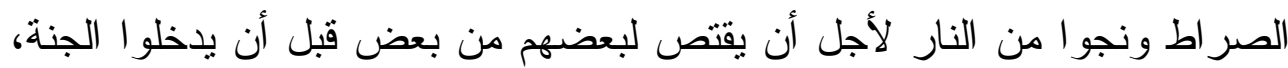

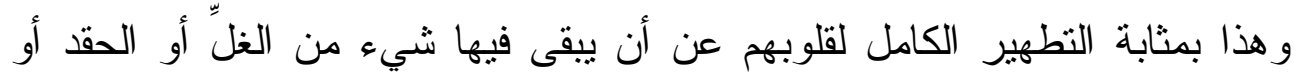

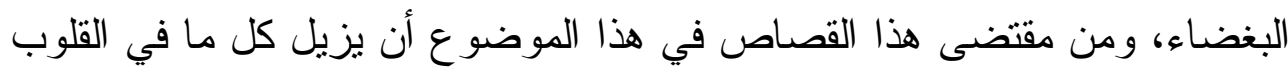

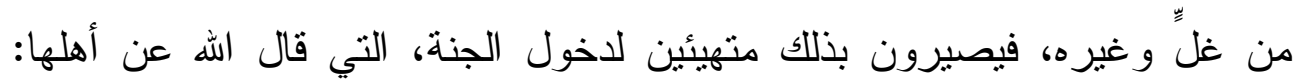

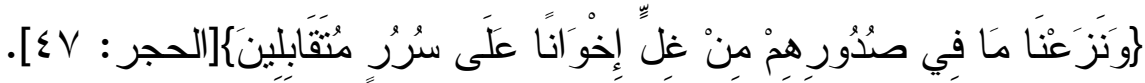

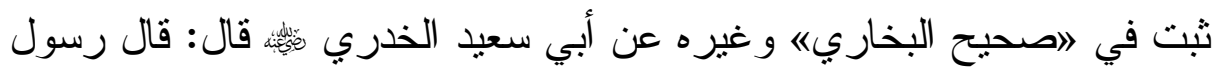

(1) موقع المأوى على شبكة المعلومات الدولية. www.almawa.net. موضوع حقيقة الصر اط.

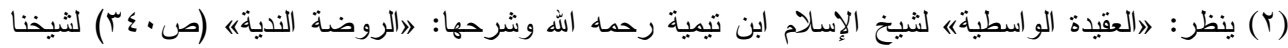
العلامة زيد الفياض رحمه الله.

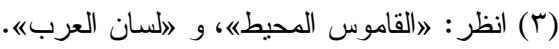


القيامة الكبرى (مشاهد ووقائع، دروس وعبر)

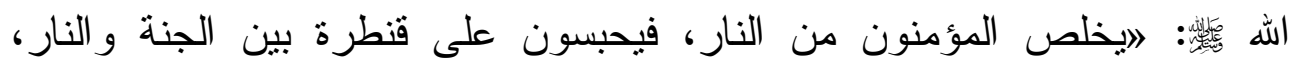

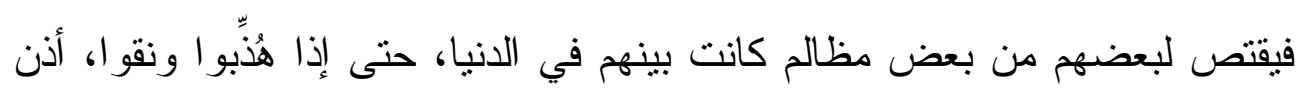

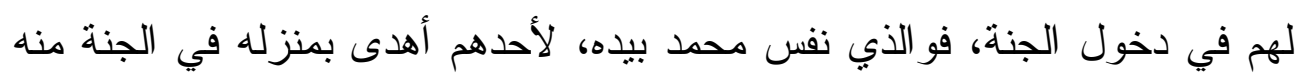

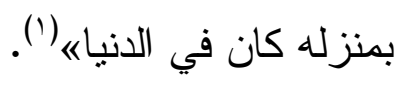

قال الحافظ ابن حجر رحمه الله في شرحه هذا الحديث(؟):

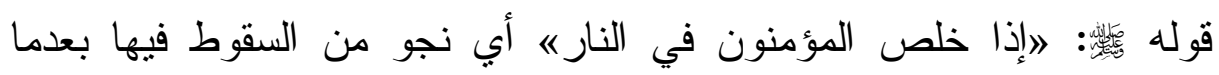

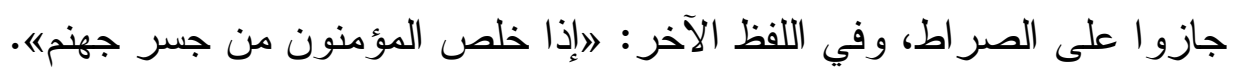
قال الحافظ القرطبي: إن هؤلاء الذين يحبسون في القنطرة هم المؤمنون الذين

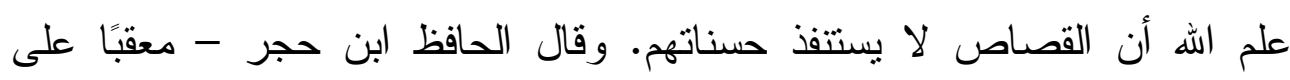
القرطبي - رحمه الله: ولعلَّ أصحاب الأعراف منهم على القول المرجح آنفاً، وخرج من هذا صنفان من المؤمنين: الأول: من دخل الجنة بغير حساب. و الثاني: من أوبقه عمله.

وقوله له : "يحبسون على قنطرة بين الجنة و النار هـ قد تقدم أن الصر اط جسر"

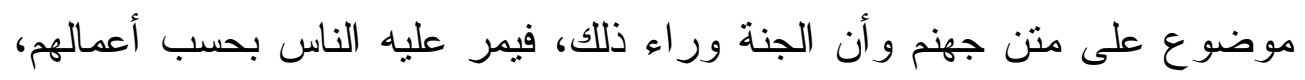

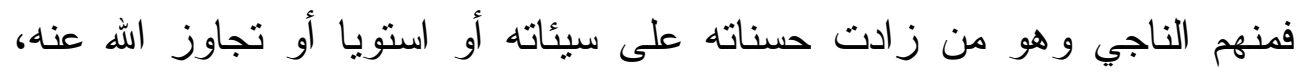

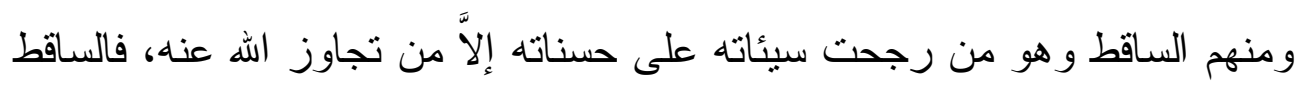

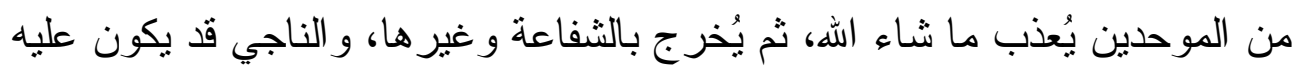

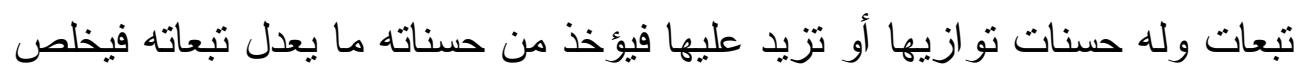


القيامة الكبرى (مشاهد ووقائع، دروس وعبر)

واختلف في القطرة المنكورة، فقيل: هي من نتمة الصراط، وهي طرفه الذي يلي

الجنة، وقيل: إنها صر اطان وبهذا الثاني جزم القرطبي (').

وقوله

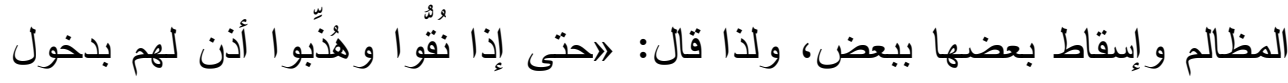

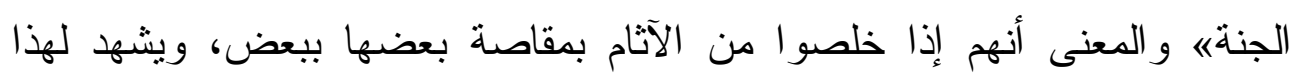
الحديث قوله في حديث جابر : الا يحل لأحدٍ من أهل الجنة أن يدخل الجنة ولأحدٍ قبتَكَه مظلمةه.اهـ شرح الحافظ ابن حجر رحمد الله ملخصنًا. ولسماحة الثيخ العلامة محمد بن صالح العثيمين نفع الله به، لفتة لطيفة عند قوله

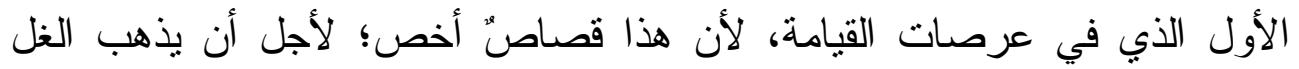

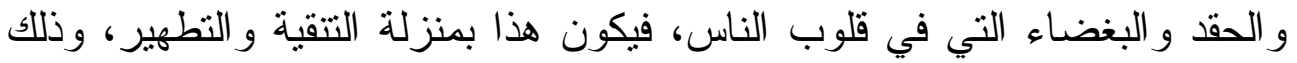

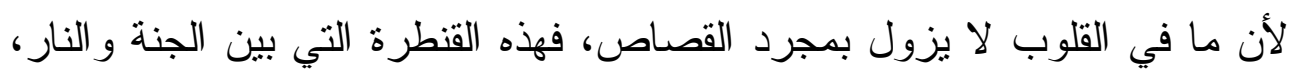

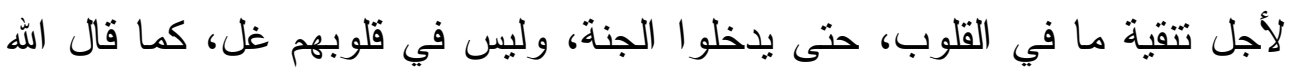

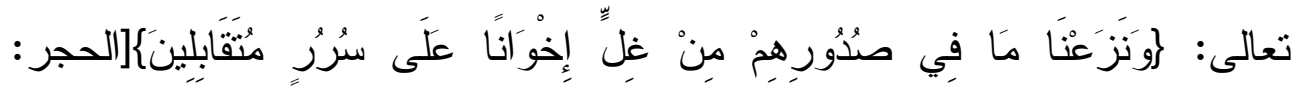
(r). [ [ $\vee V$

ما بقي أمام وفد الرحمن بعد أن نُقو ا وهُنِّبو ا من كل الخطايا و الآثام إلا أن

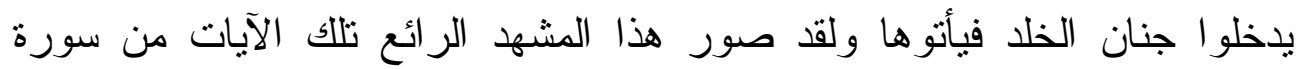

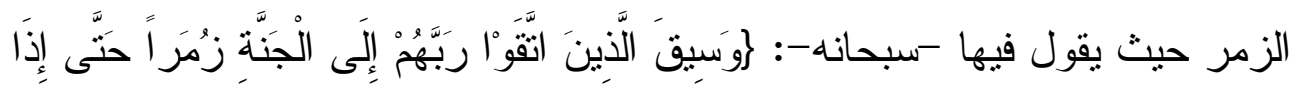

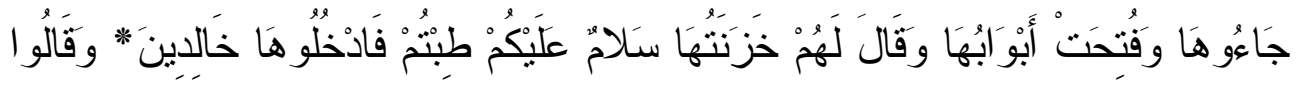

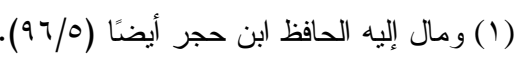

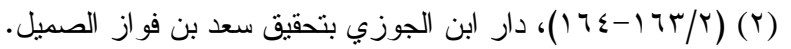




\section{القيامة الكبرى (مشاهد ووقائع، دروس وعبر)}

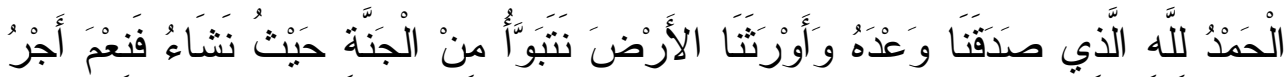

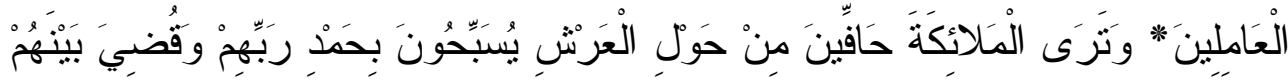

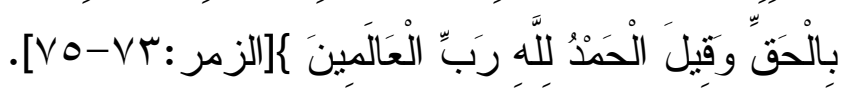

إنه مشهد الختام المتقون في جنان الخلد و الكفار في نار جهنم و الملائكة حافة حول العرش بتسبيحها وحمدها لرب الأرض و السماء وبهذا المشهد نختم هذا البحث

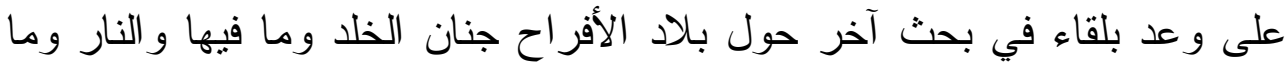
أعد للكافرين فيها. و الحمد لله أو لاً و آخراً. 
القيامة الكبرى (مشاهد ووقائع، دروس وعبر)

\section{الفهارس}

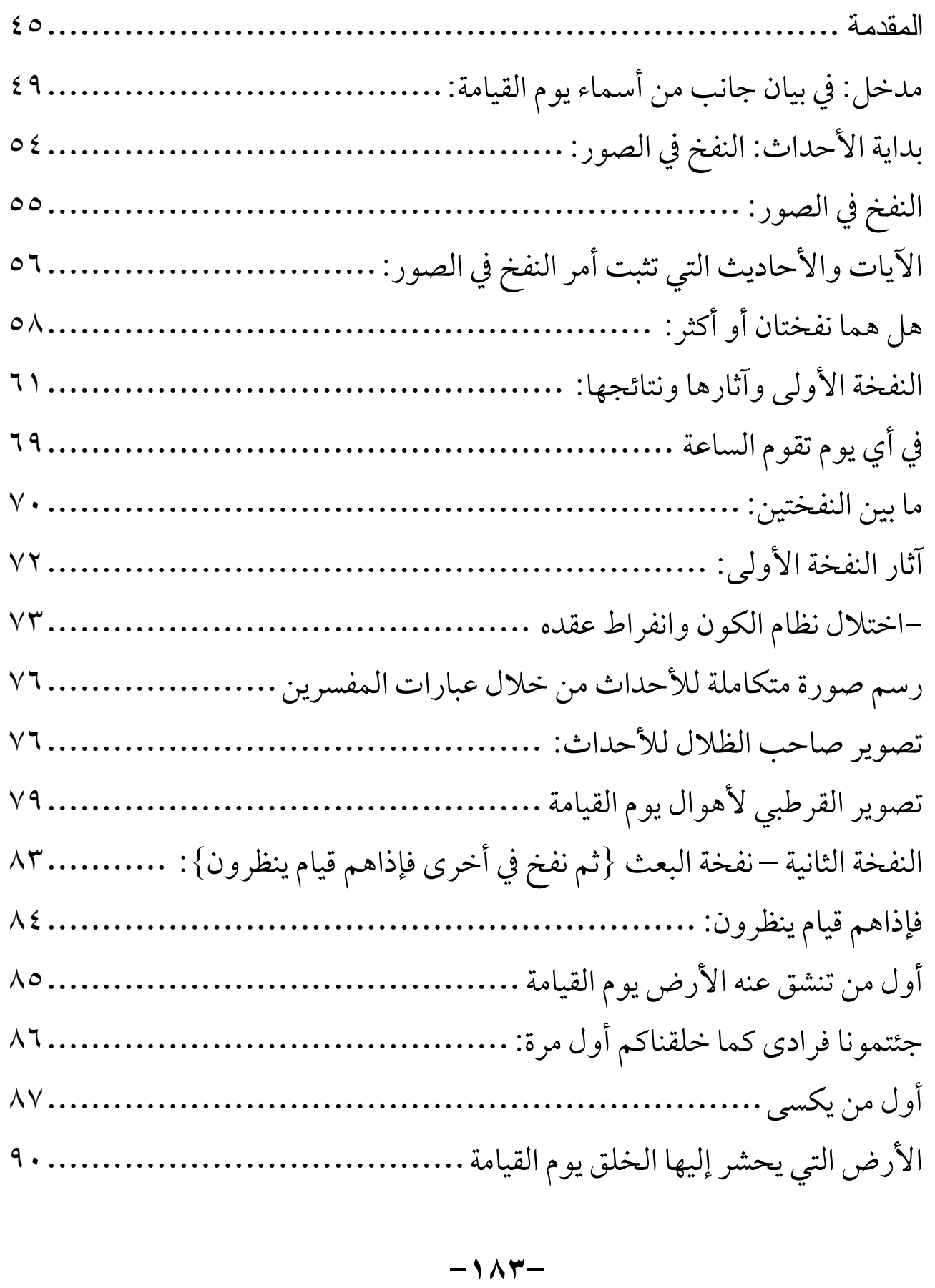


القيامة الكبرى (مشاهد ووقائع، دروس وعبر)

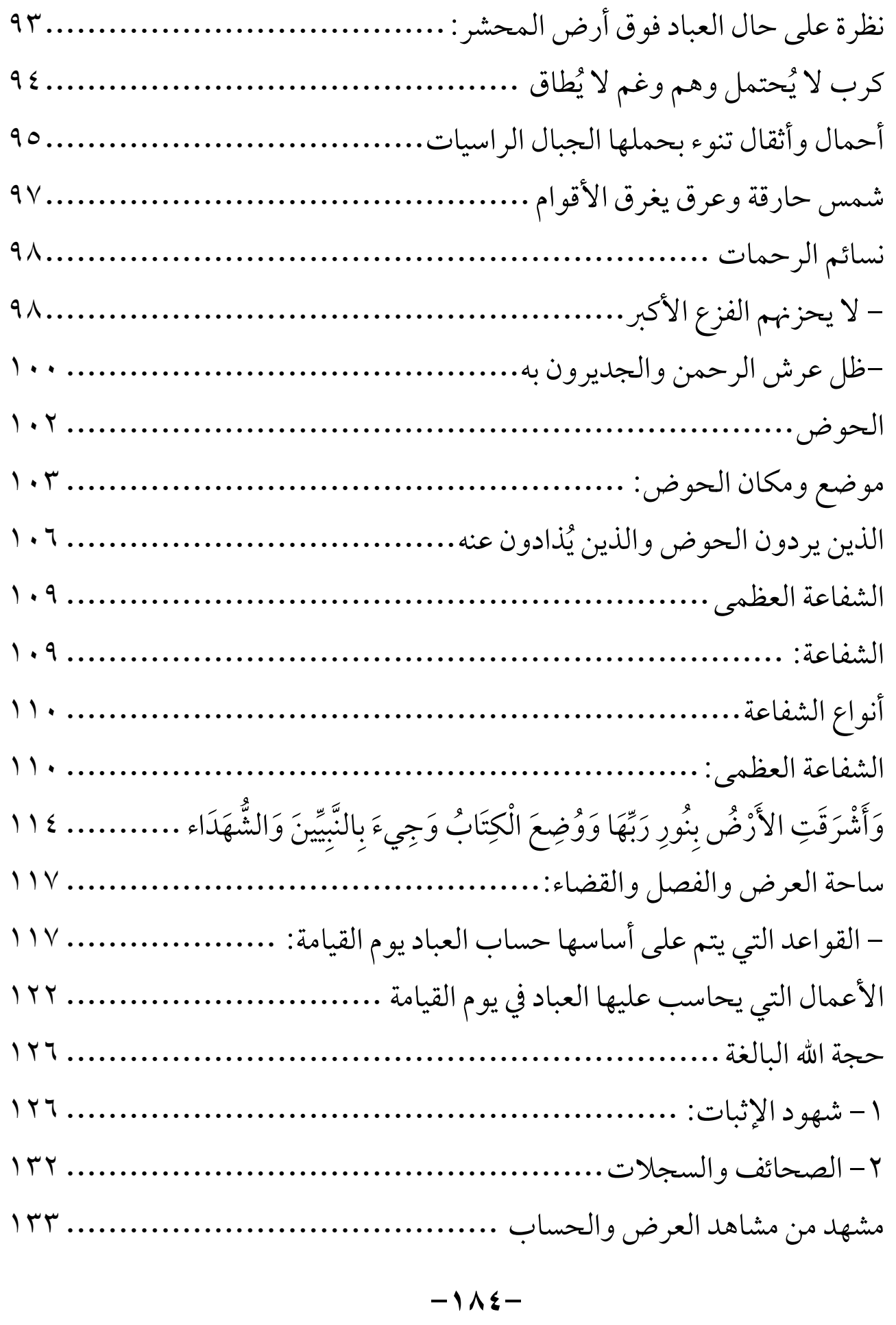


القيامة الكبرى (مشاهد ووقائع، دروس وعبر)

I

1 - فرحة وسرور أوحسرة وندامة: .

ITV

Y - ستر و مغفرة أو فضيحة وتنكيل

$1 \leq r$ القصاص بين العباد .

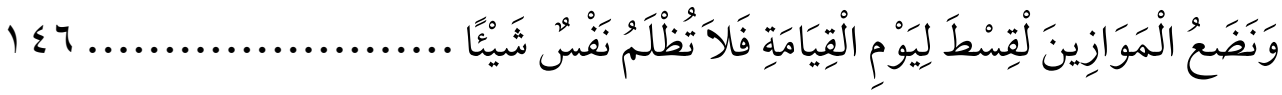

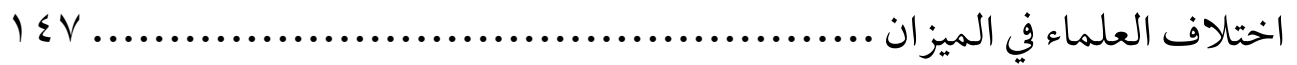

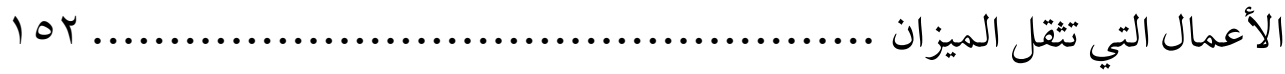

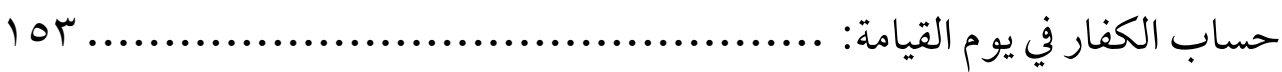

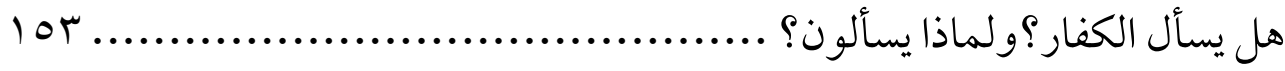

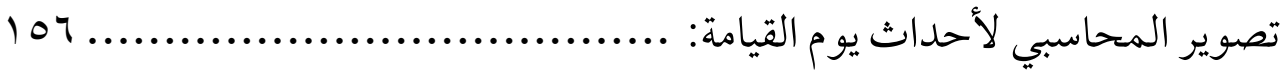

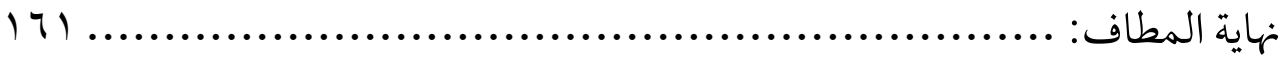

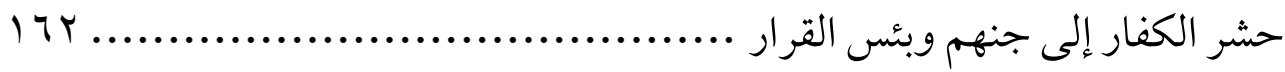

الصر اط: وفيه نقاط عدة:.............................................................

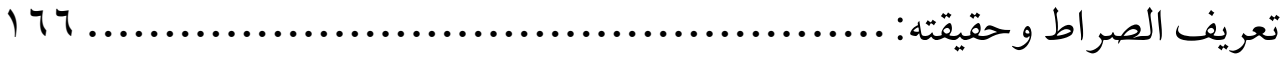

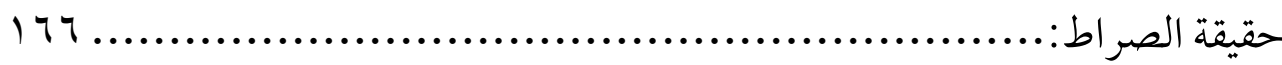

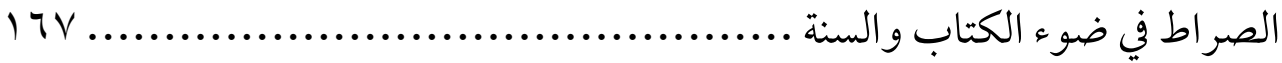

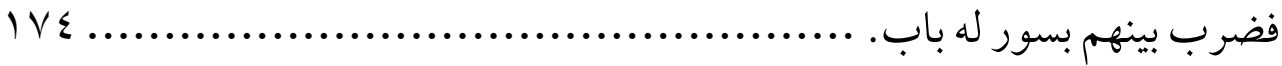

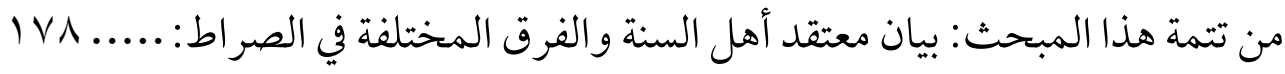

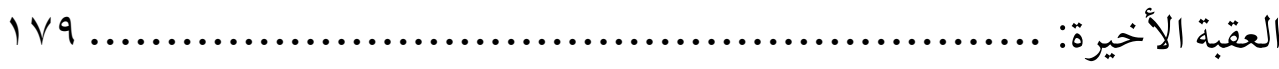

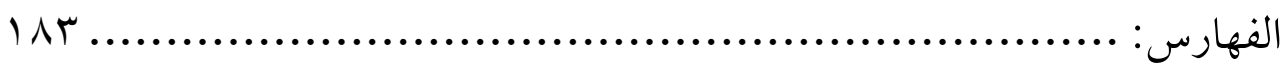


$-1117-$ 